\title{
Studies of Acute and Chronic Radiation Injury at the Biological and Medical Research Division, Argonne National Laboratory, 1970-1992: The JANUS Program Survival and Pathology Data
}

by D. Grahn, B.J. Wright, B.A. Carnes, F.S. Williamson, and C. Fox

Center for Mechanistic Biology and Biotechnology

Argonne National Laboratory, 9700 South Cass Avenue, Argonne, Illinois 60439

February 1995

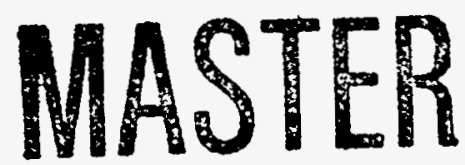

Work sponsored by the United States Department of Energy,

Office of Health and Environmental Research, under Contract No. W-31-109-Eng-38 


\section{DISCLAIMER}

This report was prepared as an account of work sponsored by an agency of the United States Government. Neither the United States Government nor any agency thereof, nor any of their employees, make any warranty, express or implied, or assumes any legal liability or responsibility for the accuracy, completeness, or usefulness of any information, apparatus, product, or process disclosed, or represents that its use would not infringe privately owned rights. Reference herein to any specific commercial product, process, or service by trade name, trademark, manufacturer, or otherwise does not necessarily constitute or imply its endorsement, recommendation, or favoring by the United States Government or any agency thereof. The views and opinions of authors expressed herein do not necessarily state or reflect those of the United States Government or any agency thereof. 


\section{DISCLAIMER}

Portions of this document may be illegible in electronic image products. Images are produced from the best available original document. 


\section{CONTENTS}

FOREWORD $\ldots \ldots \ldots \ldots \ldots \ldots \ldots \ldots \ldots \ldots \ldots \ldots \ldots \ldots \ldots \ldots$ viii

ACKNOWLEDGMENTS $\ldots \ldots \ldots \ldots \ldots \ldots \ldots \ldots \ldots \ldots \ldots \ldots \ldots \ldots$

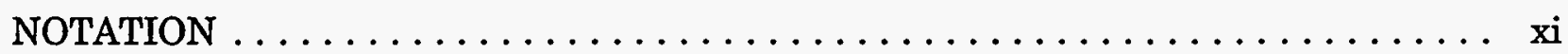

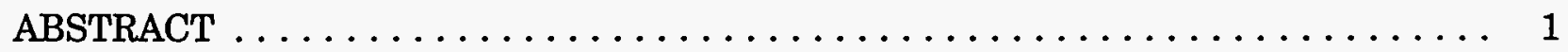

1 THE JANUS REACTOR AND RELATED FACILITIES $\ldots \ldots \ldots \ldots \ldots \ldots \ldots$

1.1 Historical Background $\ldots \ldots \ldots \ldots \ldots \ldots \ldots \ldots \ldots \ldots \ldots \ldots \ldots \ldots$

1.2 The JANUS Reactor and High-Flux Exposure Facility $\ldots \ldots \ldots \ldots \ldots \ldots$

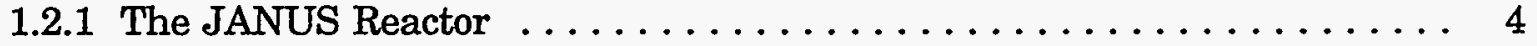

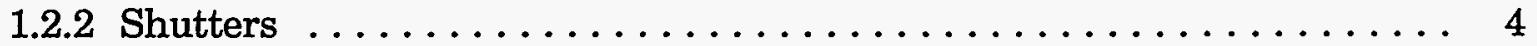

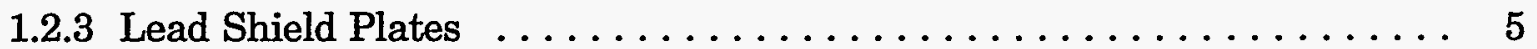

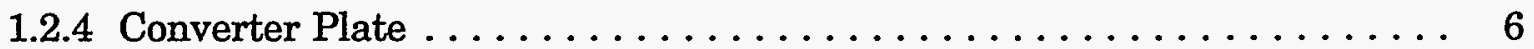

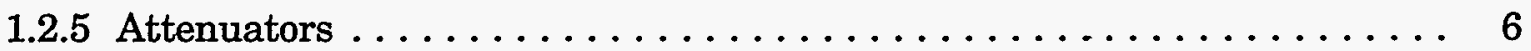

1.2.6 High-Flux Exposure Room $\ldots \ldots \ldots \ldots \ldots \ldots \ldots \ldots \ldots \ldots \ldots$

1.2.7 Animal Irradiation $\ldots \ldots \ldots \ldots \ldots \ldots \ldots \ldots \ldots \ldots \ldots \ldots \ldots \ldots \ldots \ldots \ldots$

1.3 Neutron Dosimetry . . . . . . . . . . . . . . . . . .

1.3.1 Neutron Kerma Scanning $\ldots \ldots \ldots \ldots \ldots \ldots \ldots \ldots \ldots \ldots$

1.3.2 Thermal-Neutron Contribution $\ldots \ldots \ldots \ldots \ldots \ldots \ldots \ldots \ldots \ldots \ldots$

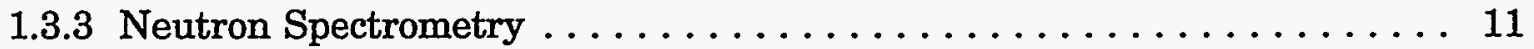

1.4 Gamma Irradiations $\ldots \ldots \ldots \ldots \ldots \ldots \ldots \ldots \ldots \ldots \ldots \ldots \ldots \ldots \ldots$

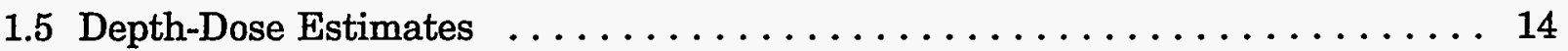

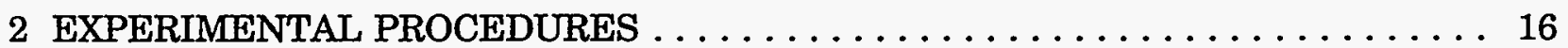

2.1 Animal Husbandry and Housing $\ldots \ldots \ldots \ldots \ldots \ldots \ldots \ldots \ldots \ldots \ldots \ldots \ldots \ldots$

2.1.1 Animal Source and Supply $\ldots \ldots \ldots \ldots \ldots \ldots \ldots \ldots \ldots \ldots \ldots \ldots \ldots \ldots \ldots$

2.1.1.1 Mus musculus ....................... 16

2.1.1.2 Peromyscus leucopus .................... 16

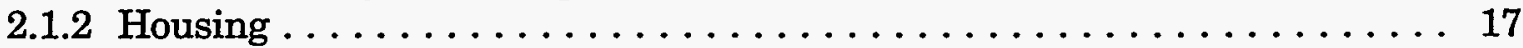

2.1.3 Animal Husbandry $\ldots \ldots \ldots \ldots \ldots \ldots \ldots \ldots \ldots \ldots \ldots \ldots \ldots \ldots$

2.2 Irradiation Procedures $\ldots \ldots \ldots \ldots \ldots \ldots \ldots \ldots \ldots \ldots \ldots \ldots \ldots \ldots$

2.3 Post-Irradiation Follow-up Protocols $\ldots \ldots \ldots \ldots \ldots \ldots \ldots \ldots \ldots \ldots \ldots$

2.3.1 Death Checks ............................. 19

2.3.2 Pathology Protocols . . . . . . . . . . . . . . . . . . 19

2.3.2.1 Necropsy Procedure .................... 19

2.3.2.2 Collection of Tissues and Preparation for Histopathology . . . . . 20

2.3.3 Histopathology Codes $\ldots \ldots \ldots \ldots \ldots \ldots \ldots \ldots \ldots \ldots \ldots . \ldots \ldots$

2.4 Record Keeping and Data Management $\ldots \ldots \ldots \ldots \ldots \ldots \ldots \ldots \ldots 21$

2.4.1 Data Entry .............................. 21

2.4.2 Specialized Data Organization .................... 22 


\section{CONTENTS (Cont.)}

2.4.3 Reliability and Potential Use of the Pathology Data ........... 23

2.4.3.1 Analysis of Concordance between the Gross and

Microscopic Pathology .................... 23

2.4.3.2 Analysis of the Discordance between the Gross

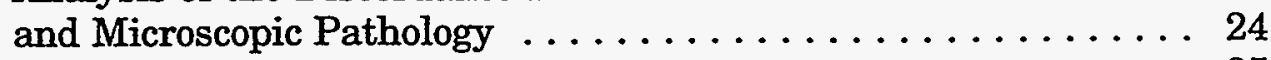

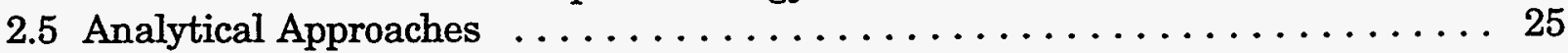

3 THE JANUS PROGRAM EXPERIMENTS $\ldots \ldots \ldots \ldots \ldots \ldots \ldots \ldots \ldots \ldots$

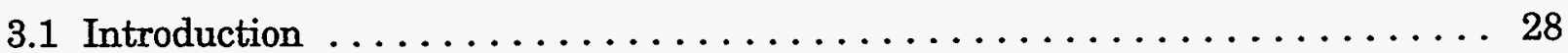

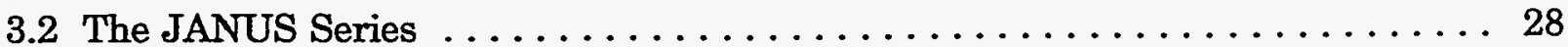

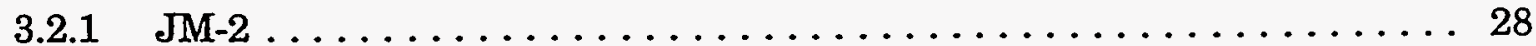

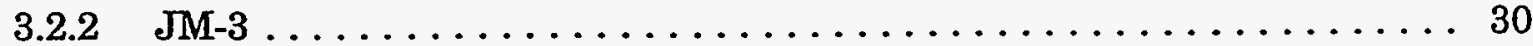

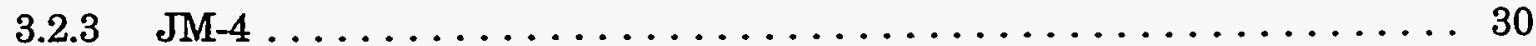

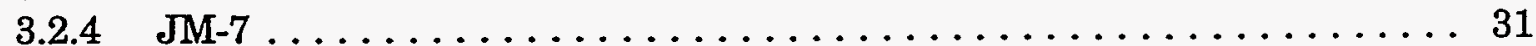

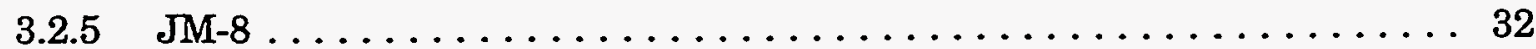

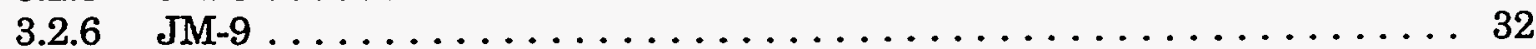

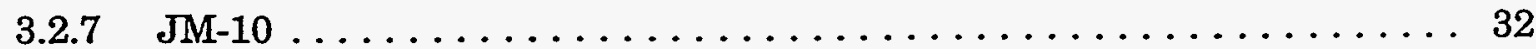

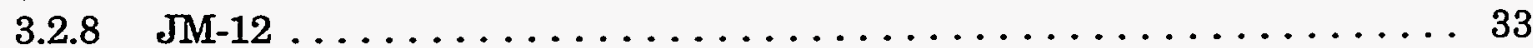

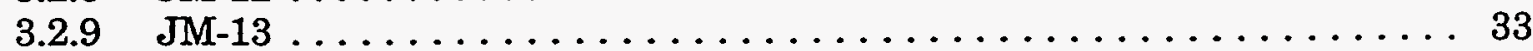

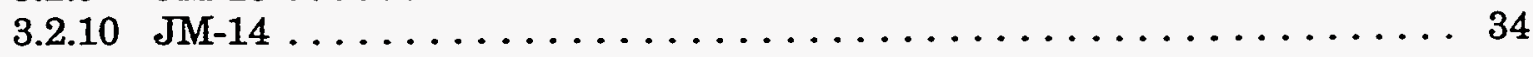

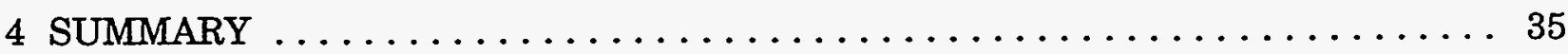

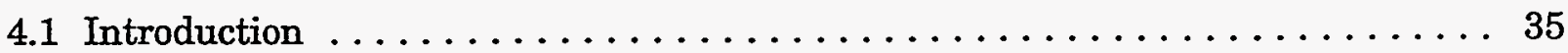

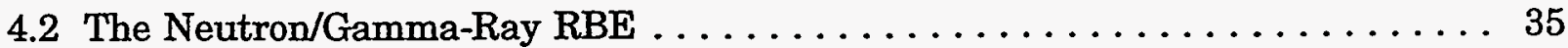

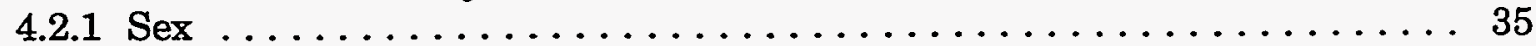

4.2.2 Total Dose/Dose Rate/Protraction Period/Fractionation Pattern . . . . . . 36

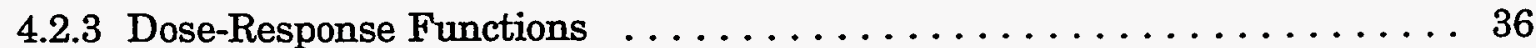

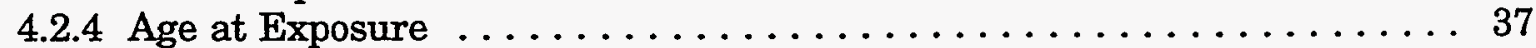

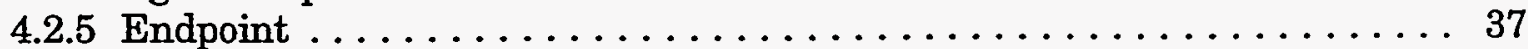

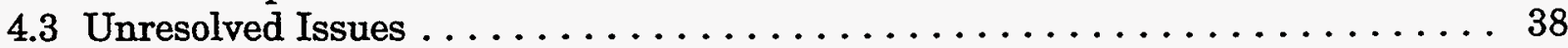

4.3.1 Dose-Response Functions $\ldots \ldots \ldots \ldots \ldots \ldots \ldots \ldots \ldots \ldots \ldots \ldots \ldots$

4.3.2 Dose Rate, Fractionation and Protraction Factors . . . . . . . . . 38

4.3.3 Age at and during Exposure $\ldots \ldots \ldots \ldots \ldots \ldots \ldots \ldots \ldots \ldots \ldots \ldots$

4.3.4 Neoplastic Diseases . . . . . . . . . . . . . . . . . . . 39

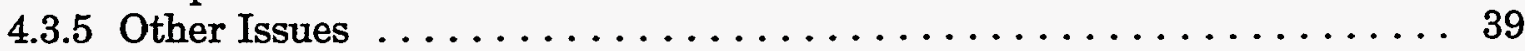

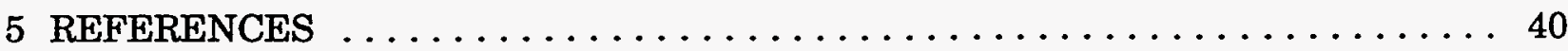




\section{CONTENTS (Cont.)}

APPENDIX A: JANUS Death Tag and Cage Card $\ldots \ldots \ldots \ldots \ldots \ldots \ldots$ A-1

APPENDIX B: JANUS Exit and Autopsy Codes $\ldots \ldots \ldots \ldots \ldots \ldots \ldots \ldots$ B-1

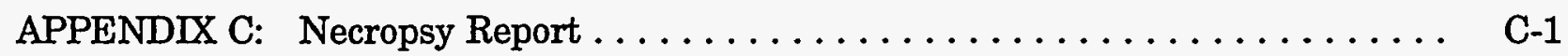

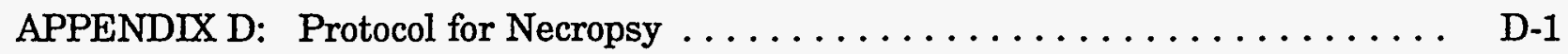

APPENDIX E: JANUS MACRO Dictionary $\ldots \ldots \ldots \ldots \ldots \ldots \ldots \ldots \ldots \ldots \ldots \ldots$

APPENDIX F: Procedure for Collection of Tissues for Histopathology $\ldots \ldots \ldots$ F-1

APPENDIX G: Histology Procedure $\ldots \ldots \ldots \ldots \ldots \ldots \ldots \ldots \ldots \ldots \ldots$ G-1

APPENDIX H: JANUS MICRO Dictionary $\ldots \ldots \ldots \ldots \ldots \ldots \ldots \ldots \ldots \ldots \ldots$

APPENDIX I: $\quad$ JANUS ORACLE Tables $\ldots \ldots \ldots \ldots \ldots \ldots \ldots \ldots \ldots \ldots$ I-1

APPENDIX J: JANUS Radiation Protocol $\ldots \ldots \ldots \ldots \ldots \ldots \ldots \ldots \ldots \ldots$ J-1

APPENDIX K: Combined Pathology Database $<$ E $>$ : MACRO and

APPENDIX L: Combined Pathology Database $<F>$ : MACRO and

MICRO Glossaries ........................ L-1

APPENDIX M: Combined Pathology Database <H>: MACRO and

MICRO Glossaries . . . . . . . .

APPENDIX N: List of Selected JANUS Publications $\ldots \ldots \ldots \ldots \ldots \ldots \ldots \ldots$

FIGURES

1 Cutaway View of a Model of the JANUS Reactor and the

High-Flux Room $\ldots \ldots \ldots \ldots \ldots \ldots \ldots \ldots \ldots \ldots \ldots \ldots \ldots \ldots \ldots \ldots \ldots \ldots \ldots$

2 Cross-Sectional View of the Reactor Shutters and Exposure Face $\ldots \ldots \ldots \ldots$

3 Interior View of the JANUS High-Flux Room Showing Loading

System of Racks Hanging along an Isodose Surface .............. 8

4 Plan View of JANUS High-Flux Room Showing Isodose Contours . . . . . . 10 


\section{FIGURES (Cont.)}

5 Neutron Energy Spectra in the High-Flux Room . . . . . . . . . . . . 12

6 Neutron Energy Spectra in the High-Flux Room, from Williamson and Frigerio $\ldots \ldots \ldots \ldots \ldots \ldots \ldots \ldots \ldots$

A.1 JANUS Death Tag $\ldots \ldots \ldots \ldots \ldots \ldots \ldots \ldots \ldots \ldots \ldots \ldots \ldots \ldots \ldots \ldots$

A.2 Cage Card $\ldots \ldots \ldots \ldots \ldots \ldots \ldots \ldots \ldots \ldots \ldots \ldots \ldots \ldots \ldots \ldots \ldots \ldots \ldots \ldots \ldots$

C.1a Necropsy Report, page $1 \ldots \ldots \ldots \ldots \ldots \ldots \ldots \ldots \ldots \ldots \ldots \ldots \ldots \ldots \ldots$

C.1b Necropsy Report, page $2 \ldots \ldots \ldots \ldots \ldots \ldots \ldots \ldots \ldots \ldots \ldots$ C-4

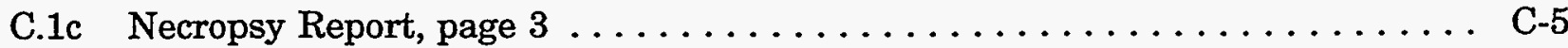

G.1 Slide Chart of Standard Tissues Taken ................. G-4

\section{TABLES}

1 Composition of Combined Pathology Database $<E>\ldots \ldots \ldots \ldots \ldots . \ldots 4$

2 Composition of Combined Pathology Database $<F>\ldots \ldots \ldots \ldots \ldots$

3 Composition of Combined Pathology Database $<\mathrm{H}>\ldots \ldots \ldots \ldots \ldots \ldots .45$

4 JANUS Program Records Summary $\ldots \ldots \ldots \ldots \ldots \ldots \ldots \ldots \ldots$

5 Analysis of Concordance between Gross and Microscopic Findings for the Classifications of Lethal, Lethal Plus Contributory, and All Observed Pathology . . . . . . . . . . . . . . . . . . . . 46

6 Analysis of Discordance between Gross and Microscopic Pathology. . . . . . . 47

7 Inventory of Death and Pathology Records for Experiment JM-2 $\ldots \ldots \ldots \ldots$

8 Inventory of Death and Pathology Records for Experiment JM-3 . . . . . . . 49

9 Inventory of Death and Pathology Records for Experiments JM-4K

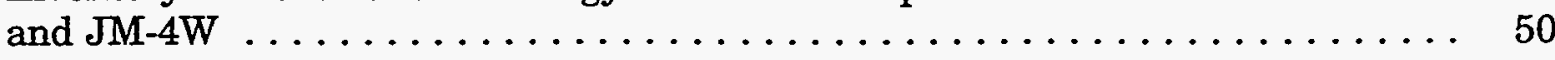

10 Inventory of Death and Pathology Records for Experiments JM-4L1

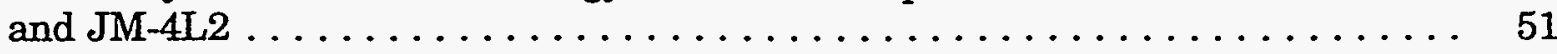

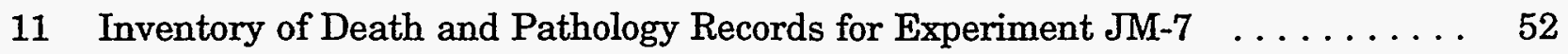




\section{TABLES}

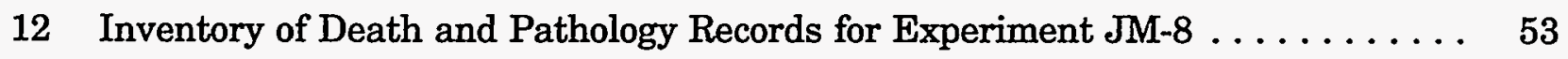

13 Inventory of Death and Pathology Records for Experiment JM-9 . . . . . 54

14 Inventory of Death and Pathology Records for Experiment JM-10 . . . . . 55

15 Inventory of Death and Pathology Records for Experiment JM-12 $\ldots \ldots \ldots \quad 55$

16 Inventory of Death and Pathology Records for Experiment JM-13 . . . . 56

17 Inventory of Death and Pathology Records for Experiment JM-14 . . . . . 57 


\section{FOREWORD}

In May 1994, the Center for Mechanistic Biology and Biotechnology of Argonne National Laboratory (ANL) published a report, ANL-94/26, that described the studies on acute and chronic radiation injury performed at the laboratory from 1953 to 1970 . The present document covers the period from 1970 to 1992 and deals specifically with the survival and pathology data accrued during the course of the JANUS program. These data are from studies that used the JANUS reactor located in Building 202 at Argonne.

What might be the most remarkable fact about the JANUS program is that it actually came to pass. While this document cannot provide the detailed history of JANUS, both as a reactor and as a program, it can be said that the reactor itself had an unusual conception, a protracted and difficult gestation, and came perilously close to being stillborn. Conception occurred in the spring of 1958, but approval for full-power operation of the reactor finally used for the studies described in this document was not given until the spring of 1970. The intervening 12 years saw repeated safety reviews and evaluations of the reactor. In 1966, significant and unusual modifications were proposed to resolve some difficult safety and usability issues. These modifications were implemented, with the result that JANUS was born again in 1970, now as a sophisticated neutron source solely dedicated to experimental radiobiology. A brief history and description of the JANUS reactor facility is presented here with enough detail so that the unusual features can be understood and appreciated; the generation of a "clean" fission-neutron flux for experimental biology is a complex challenge.

After 22 years of successful operation, increases in operating costs, the age of the facility, and changes in program priority severely restricted the need for continuing the reactor's operation. In a letter to ANL management dated November 6, 1992, the Department of Energy ordered that the JANUS reactor be shut down. Authorization to remove the fuel elements and converter plates was given in January 1993. The elements were removed in February and March 1993, and the last fuel elements were shipped to the Savannah River Facility on March 24, 1993. 


\section{ACKNOWLEDGMENTS}

In the course of a major program that existed for about a quarter of a century, many regular staff scientists, technical staff, and temporary staff participated, contributed, and moved on. The following list includes those who participated at some time between 1965 and 1994. All manner of expertise in experimental biology, pathology, physics, and statistics is represented in this cadre, and their individual and collective contributions are herewith acknowledged with great appreciation.

Scientific staff:

$\begin{array}{lll}\text { E.J. Ainsworth } & \text { R.J.M. Fry } & \text { W.K. Sinclair } \\ \text { T.B. Borak } & \text { D. Grahn } & \text { S.P. Stearner } \\ \text { P.A. Brennan } & \text { D.J. Grdina } & \text { J.F. Thomson } \\ \text { B.A. Carnes } & \text { L.S. Lombard } & \text { S.A. Tyler } \\ \text { N.A. Frigerio } & \text { G.A. Sacher } & \text { F.S. Williamson }\end{array}$

Technical support staff:

$\begin{array}{lll}\text { K.H. Allen } & \text { E.G. Johnson, Jr. } & \text { J.M. Perrin } \\ \text { E.J.B. Christian } & \text { D.L. Jordan } & \text { A.R. Sallese } \\ \text { E.M. Cooke } & \text { W.T. Kickels } & \text { M.H. Sanderson } \\ \text { P.J. Dale } & \text { R.A. Lea } & \text { E.F. Staffeldt } \\ \text { R.L. Devine } & \text { C.H. Lee } & \text { J.E. Trier } \\ \text { B.H. Farrington } & \text { V.A. Ludeman } & \text { C. Weber } \\ \text { G.L. Holmblad } & \text { M. Miller } & \text { B.J. Wright } \\ \text { J.L. Hulesch } & \text { M.P. Nielsen } & \end{array}$

Temporary staff, visiting scientists, post-doctoral appointees:

$\begin{array}{lll}\text { M.H. Branson } & \text { W.R. Hanson } & \text { J.H. Rust } \\ \text { A.V. Carrano } & \text { L.B. Hubbard } & \text { B.R. Scott } \\ \text { R.F. Coley } & \text { I.R. Marshall } & \text { C.P. Sigdestad } \\ \text { D.A. Crouse } & \text { P.J. Meechan } & \text { R.M. Vigneulle } \\ \text { R.C. Dickerman } & \text { P. Mitacek, Jr. } & \text { T.C.H. Yang } \\ \text { M.L. Garriott } & \text { B. Nagy } & \text { V.V. Yang }\end{array}$

We also acknowledge the continued support and assistance received from the Animal Facilities veterinary staff (R.J. Flynn, DVM; T.E. Fritz, DVM; C.M. Poole, DVM) and from dozens of animal care specialists. The veterinary staff supervised the production of a consistently high-quality experimental animal, the $\mathrm{B}_{6} \mathrm{CF}_{1}$ hybrid mouse, in adequate numbers and in a timely manner. Many of the specialists proved especially skilled in the complex, computer-controlled animal loading and unloading procedures that were an essential part of the exposure process and the individual animal's experimental history.

Obviously, consistent and reliable operation of the JANUS reactor had to be maintained for the overall program to continue according to plan. Although the (former) 
Division of Biological and Medical Research did not have direct responsibility for reactor operations and safety, programmatic needs were always achieved because of highly cooperative and competent operational crews. 


\section{NOTATION}

\section{Abbreviations}

$\begin{array}{ll}\text { AEC } & \text { Atomic Energy Commission } \\ \text { ANL } & \text { Argonne National Laboratory } \\ \text { BIM } & \text { Biological and Medical Research Division } \\ \text { Co } & \text { cobalt } \\ \text { He } & \text { helium } \\ \text { HLGF } & \text { High-Level Gamma Facility } \\ K & \text { kerma (measured in gray [Gy]) } \\ \text { MAS } & \text { mean after-survival } \\ \text { MDI } & \text { menu-driven interface } \\ \text { n } & \text { neutron } \\ \text { p } & \text { proton } \\ \text { RBE } & \text { relative biological effectiveness } \\ \text { SE } & \text { standard error } \\ \text { SPF } & \text { specific-pathogen-free } \\ \text { U } & \text { uranium }\end{array}$

\section{Units}

$\begin{array}{ll}\text { cGy } & \text { centigray } \\ \mathrm{cm} & \text { centimeter } \\ \mathrm{d} & \text { day } \\ \mathrm{ft} & \text { foot } \\ \mathrm{g} & \text { gram } \\ \mathrm{h} & \text { hour } \\ \mathrm{in} & \text { inch } \\ \mathrm{keV} & \text { kiloelectron volt } \\ \mathrm{kW} & \text { kilowatt } \\ \mathrm{kW}(\mathrm{th}) & \text { kilowatt (thermal) } \\ \mathrm{L} & \text { liter } \\ \mathrm{m} & \text { meter } \\ \mathrm{\mu m} & \text { micrometer } \\ \mathrm{MeV} & \text { megaelectron volt } \\ \mathrm{min} & \text { minute } \\ \mathrm{mL} & \text { milliliter } \\ \mathrm{mm} & \text { millimeter } \\ \mathrm{N} & \text { normal } \\ \mathrm{pt} & \text { pint } \\ \mathrm{R} & \text { roentgen } \\ \mathrm{s} & \text { second } \\ \mathrm{W} & \text { watt } \\ \mathrm{wk} & \text { week } \\ \mathrm{yr} & \text { year } \\ & \end{array}$




\title{
STUDIES OF ACUTE AND CERONIC RADIATION \\ INJURY AT THE BIOLOGICAL AND MEDICAL RESEARCH \\ DIVISION, ARGONNE NATIONAL LABORATORY, 1970-1992: THE JANUS PROGRAM SURVIVAL AND PATHOLOGY DATA
}

\author{
D. Grahn, B.J. Wright, B.A. Carnes, \\ F.S. Williamson, and C. Fox
}

\begin{abstract}
A research reactor for exclusive use in experimental radiobiology was designed and built at Argonne National Laboratory in the 1960s. It was located in a special addition to Building 202, which housed the Division of Biological and Medical Research. Its location assured easy access for all users to the animal facilities, and it was also near the existing gammairradiation facilities. The water-cooled, heterogeneous $200-\mathrm{kW}$ (th) reactor, named JANUS, became the focal point for a range of radiobiological studies gathered under the rubric of "the JANUS program." The program ran from about 1969 to 1992 and included research at all levels of biological organization, from subcellular to organismic. More than a dozen moderateto large-scale studies with the $\mathrm{B} 6 \mathrm{CF}_{1}$ mouse were carried out; these focused on the late effects of whole-body exposure to gamma rays or fission neutrons, in matching exposure regimes. In broad terms, these studies collected data on survival and on the pathology observed at death. A deliberate effort was made to establish the cause of death. This archive describes these late-effects studies and their general findings. The database includes exposure parameters, time of death, and the gross pathology and histopathology in codified form. A series of appendices describes all pathology procedures and codes, treatment or irradiation codes, and the manner in which the data can be accessed in the ORACLE database management system. A series of tables also presents summaries of the individual experiments in terms of radiation quality, sample sizes at entry, mean survival times by sex, and number of gross pathology and histopathology records.
\end{abstract}


2 


\section{THE JANUS REACTOR AND RELATED FACILITIES}

\subsection{HISTORICAL BACKGROUND}

The Division of Biological and Medical Research (BIM) of the Argonne National Laboratory (ANL) initiated a program in neutron radiobiological research in the early $1950 \mathrm{~s}$. A fission-neutron ${ }^{60} \mathrm{Co} \gamma$ irradiation chamber was employed in conjunction with an open thermal-neutron column initially at the ANL research reactor CP-3' and later at CP-5 (Vogel et al. 1953). Plans to increase the reactor power level at CP-5 necessitated the consideration to build a small research reactor solely for biomedical research at BIM. Atomic Energy Commission (AEC) approval to build the reactor was given in October 1958.

The original concept of JANUS was to build a small reactor with two exposure faces to be located on opposite sides of the core (thus the name JANUS, the two-faced deity in Roman mythology). One face would be for a high-level exposure room and one for low-level exposure. The two-faced concept was attractive, although the operational requirements and constraints were never thought through. Ultimately, only the high-level exposure face was needed.

The design and construction of JANUS was not untroubled, and although initial criticality was achieved in August 1964, full power (200 kW, thermal) was not permitted for safety reasons until May 1965. Serious safety issues affecting both reactor operations personnel and users then emerged. Neutron leakage around the shutter operating mechanisms and neutron-induced activation products in the walls of the exposure rooms placed severe limitations on reactor power levels and on access to the exposure rooms. Modifications of the exposure rooms and shutters and related components were going to be required if JANUS was to become a useful research facility.

On AEC orders, JANUS was shut down while the required modifications were considered. Approval was given by AEC in early 1968 for modifications that were limited to the high-level exposure side and exposure room. The proposed modifications were actually quite clever and innovative in the fields of reactor design and physics. As a result, when all was done and JANUS was recertified in 1970, the facility emerged as a unique neutron irradiation facility with an excellent fission-neutron flux in terms of the energy spectrum, extremely low levels of $\gamma$-ray and thermal-neutron contamination, and a comparatively homogeneous radiation field in the exposure room that would permit large numbers of small animals to be irradiated at a single dose level at one time. Dose rate was also easily controlled by varying the reactor power level. JANUS was a perfect manifestation of the old adage, "If you've got a lemon, make lemonade." In this instance, the "lemonade" was of high quality. 


\subsection{THE JANUS REACTOR AND HIGH-FLUX EXPOSURE FACHITY}

Detailed descriptions of the JANUS facility have been published in several articles (Grahn et al. 1972; ICRU 1979). The description from Grahn et al. (1972) is presented here in an abbreviated form to provide a good general sense of the overall facility, dosimetry, and exposure protocols. This descriptive material (Section 1.2.1 through the next-to-last paragraph of Section 1.3.3) has been left in the grammatical present tense; it describes the operating facility as it was between 1970 and 1984.

\subsubsection{The JANUS Reactor}

JANUS is a $200-\mathrm{kW}$ (th) reactor that is cooled and moderated by light water. The core can accommodate 19 fuel elements, which consist of a uranium-aluminum alloy enriched to $93 \%$ in ${ }^{235} \mathrm{U}$. The present fuel loading is approximately $2.5 \mathrm{~kg}$ of ${ }^{235} \mathrm{U}$. There are two opposing faces of the reactor, which are provided with graphite thermal columns and movable shields (shutters) so that thermal neutrons may enter the exposure room adjacent to each face. Converter plates containing ${ }^{235} \mathrm{U}$ may be raised into position at each face so that a source of fast fission neutrons is presented to each exposure room. At the present time, the low-flux room is not being used. Low-intensity neutron irradiations are obtained in the high-flux room by reducing the reactor power level. The system operates in a stable manner between $20 \mathrm{~W}$ and $200 \mathrm{~kW}$ to provide at least a $10^{4}$ range of dose rates.

Figure 1, a cutaway view of the reactor and the exposure room, reveals the relationships among the important features. Figure 2 is a cross-sectional view of the shutters and exposure face. The important aspects of the features of the exposure room are described below.

\subsubsection{Shutters}

The high-flux room shutters are $28.25 \mathrm{in} .(71.8 \mathrm{~cm})$ thick and are fabricated to give a stepped joint at closure against the shutter pedestals. The shutters and upper part of the pedestals are designed for optimum neutron shielding, using 2 in. $(5.1 \mathrm{~cm})$ of lead followed by borated polyethylene bricks. The gaps between the bricks are not expected to allow significant neutron leakage paths, but, should this be a problem, the shutters and pedestals both have provision for liquid filling by vacuum impregnation. The shutters are moved in or out of position within a 5-s period by means of a pneumatic drive system located on the floor level above the reactor (Figure 2). 


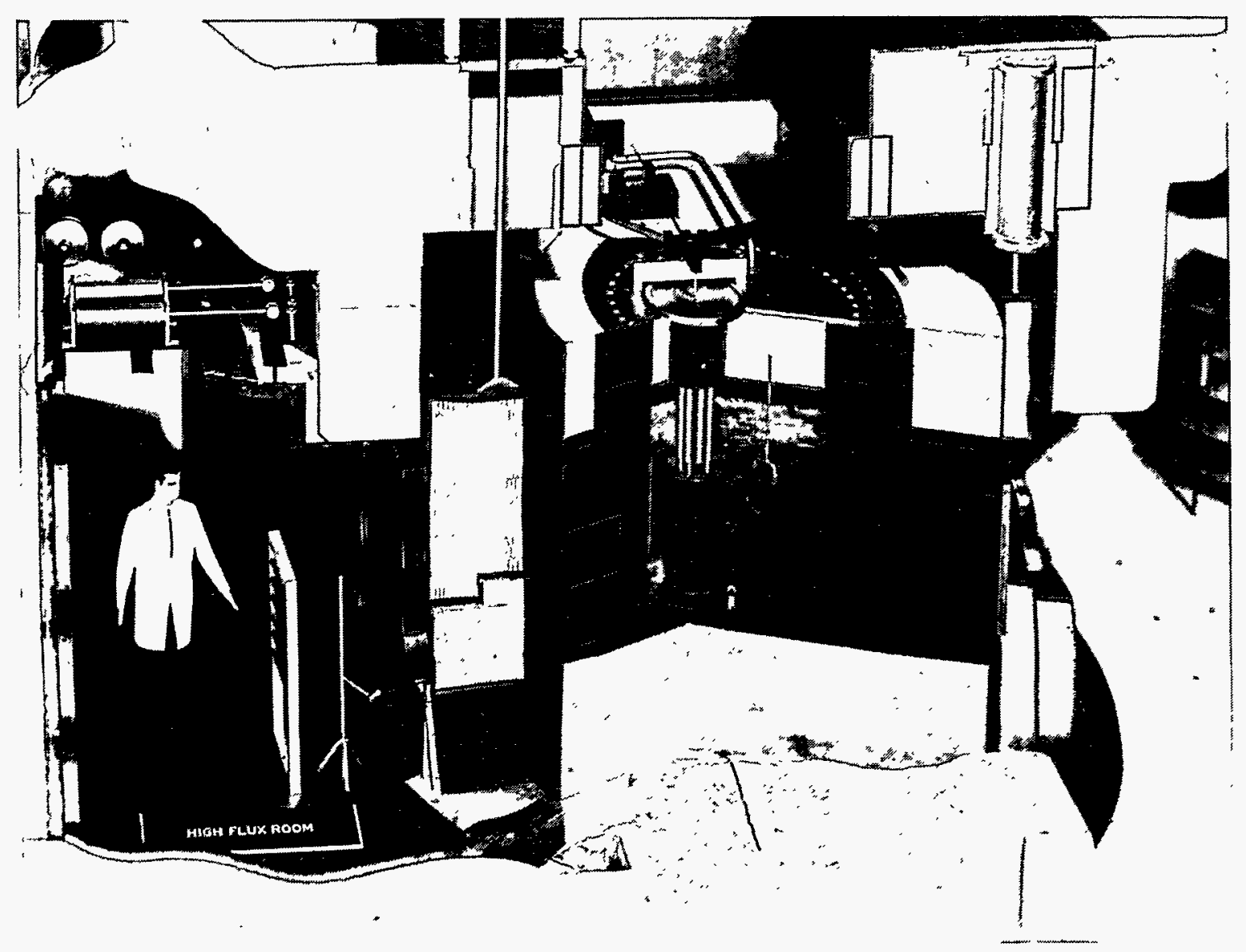

FIGURE 1 Cutaway View of a Model of the JANUS Reactor and the High-Flux Room

\subsubsection{Lead Shield Plates}

To provide adequate shielding against reactor-core $\gamma$ radiation, 9 in. $(22.9 \mathrm{~cm})$ of lead is interposed between the shutters and the exposure room (Figure 2). This lead is in the form of curved plates, $46 \mathrm{in.}(116.8 \mathrm{~cm}$ ) high, 7 in. $(17.8 \mathrm{~cm})$ wide, and $1 \mathrm{in} .(2.5 \mathrm{~cm})$ thick. Measurements made on a simulation of this geometry indicated that 2 in. $(5.1 \mathrm{~cm})$ of lead would probably reduce prompt $\gamma$ radiation from the converter plate to an insignificant level. Because transmission through lead has a deleterious effect on the high-energy end of a fission-neutron spectrum, the 9 in. $(22.9 \mathrm{~cm})$ is disposed in two locations: $7 \mathrm{in} .(17.8 \mathrm{~cm})$ on the reactor side of the converter and $2 \mathrm{in}$. $(5.1 \mathrm{~cm})$ on the exposure room side. 


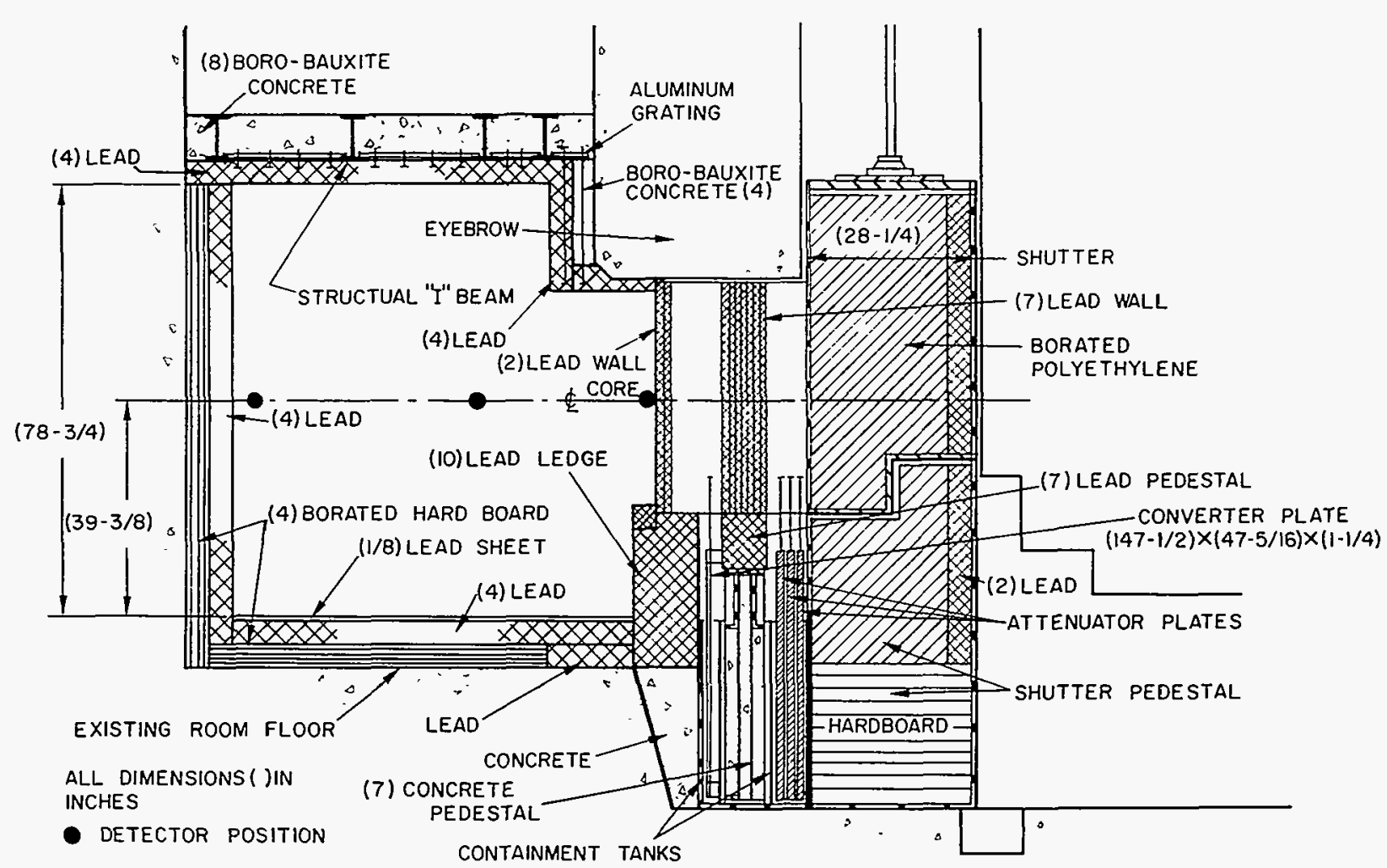

FIGURE 2 Cross-Sectional View of the Reactor Shutters and Exposure Face (exposure room at left, reactor at right)

\subsubsection{Converter Plate}

The converter plate contains a minimum of material that would scatter the fission neutrons and thereby degrade the spectrum. It consists of 34 foils, each $4 \times 39$ in. $(10.2 \times 99.1 \mathrm{~cm})$ and 0.021 in. $(0.05 \mathrm{~cm})$ thick, encased in a jacket of stainless steel foil $0.007 \mathrm{in} .(0.02 \mathrm{~cm})$ thick. Each foil contains approximately $1 \mathrm{~kg}$ of ${ }^{235} \mathrm{U}$. The foils are clamped between curved channel sections, which form the support frame.

\subsubsection{Attenuators}

Space is provided for three attenuators between the shutters and the 7-in. (17.8-cm)-thick lead wall section, but only one attenuator is being used. This is a graded attenuator to modify the distribution of thermalneutron flux incident on the converter plate so that the neutron isodose contour in the exposure room may be shaped as required. 


\subsubsection{High-Flux Exposure Room}

The concrete walls and floor are covered by a 4 -in. (10.2-cm) layer of a borated hardboard. This material is, in turn, covered by 4 in. $(10.2 \mathrm{~cm})$ of lead. A false ceiling consists of tiles of lead, $12 \times 12$ in. $(30.5 \times 30.5 \mathrm{~cm})$ and 4 in. $(10.2 \mathrm{~cm})$ thick, suspended by embedded aluminum studs from an aluminum grid work supported on the lower flanges of steel I-beams. These steel flanges are coated with a neutron-absorbing paint, consisting of gadolinium oxide in a polyurethane vehicle, in order to reduce neutron activation to a minimum. The lead ceiling assembly has 8 in. $(20.3 \mathrm{~cm})$ of a bauxite concrete, containing boron carbide, on the upper side to reduce neutron activation in the crawl space above. The false ceiling is located so that ceiling and floor are approximately symmetrical to the center line of the reactor face; this leaves a convenient crawl space, accessible from above, for the installation of four drive systems for the converter and attenuators.

This treatment of the walls, floor, and ceiling has effectively eliminated the problem of activation $\gamma$ radiation from the concrete. Neutrons are either reflected back into the room or thermalized by the layer of hardboard. Gamma radiation emitted by activation products that might be induced in the wall are then reduced to insignificant levels by this 4-in. $(10.2-\mathrm{cm})$ lead shielding. This wall treatment has been particularly successful in reducing the thermal-neutron component of the full neutron energy spectrum.

\subsubsection{Animal Irradiation}

Mice will be irradiated without food or water, housed singly in small polyethylene containers (about $500 \mathrm{~cm}^{3}$ in volume) without lids. The containers are snapped into place in a shelf module of five mice, which corresponds to one living-cage unit. The shelf prevents the mice from escaping and is perforated to provide adequate ventilation. The shelves are stacked in a loading frame of up to 12 shelves, which is hung on a framework in the exposure room (Figure 3). These frames and shelves are made from a magnesium-aluminum alloy to minimize neutron activation.

\subsection{NEUTRON DOSIMETRY}

An acetylene and argon ionization chamber pair, described by Neary and Williamson (1961), is used for kerma measurements in mixed neutron and $\gamma$-ray fields. Chamber constants are those calculated by Batchelor for the Harwell GLEEP (Graphite Low Energy Experimental Pile) 


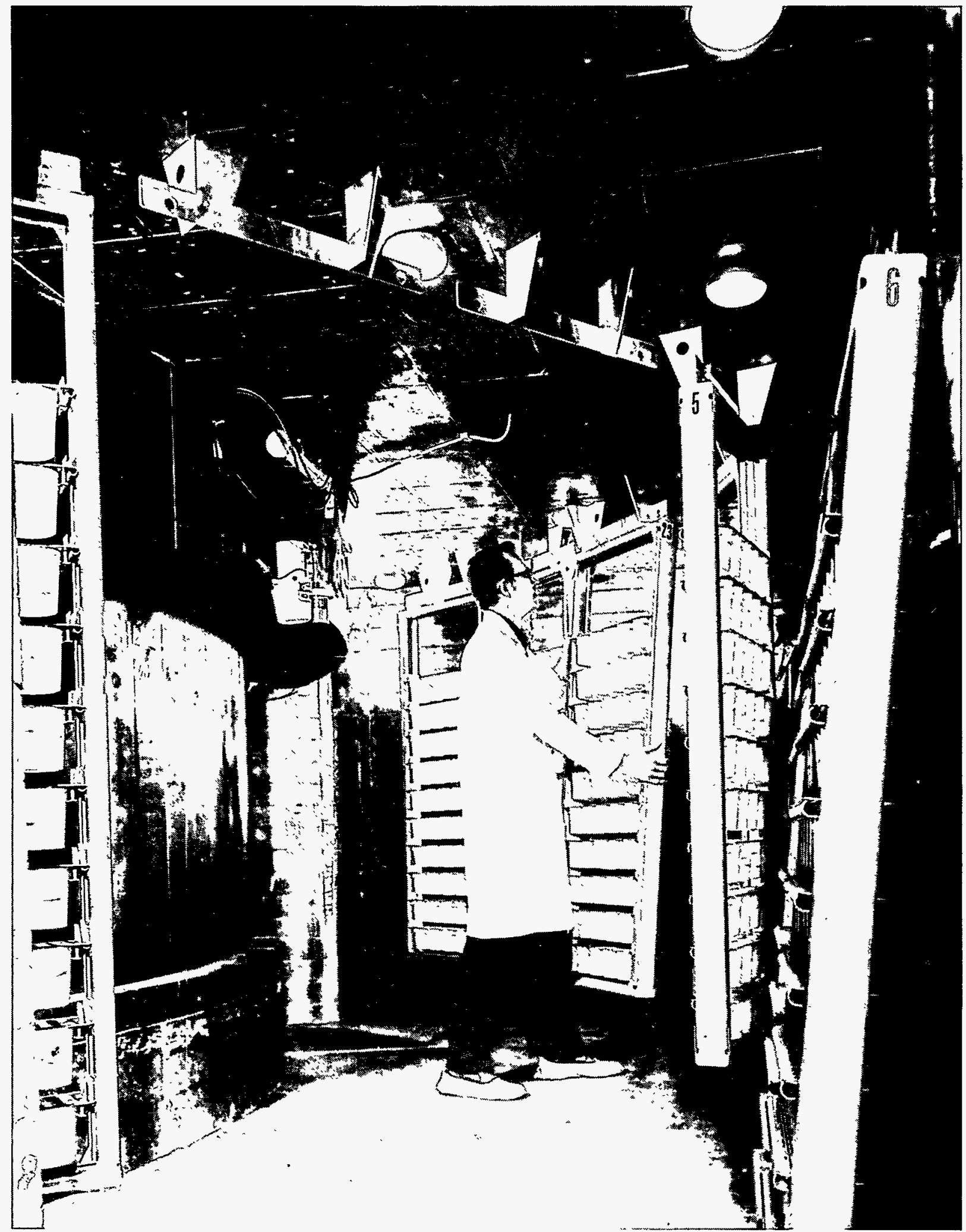

FIGURE 3 Interior View of the JANUS High-Flux Room Showing Loading System of Racks Hanging along an Isodose Surface (see Figure 4) 
facility, using the variable-W model proposed by Neary et al. (1957). Chamber volumes and electrometer sensitivity are always measured by exposure in our High-Level Gamma Radiation Facility (HLGF), hence any calibration changes in that facility will have no effect on neutron/ $\gamma$-ray relative biological effectiveness (RBE) values.

Gamma field measurements are made with an air-equivalent Victoreen Model 415 Intercomparison Standard chamber. Depth-dose measurements in all cases are made using $0.05-\mathrm{mL}$ muscle-equivalent and magnesium-walled argon chambers made and contributed by the late F.R. Shonka of the Physical Sciences Laboratory, Illinois Benedictine College, Lisle, Mlinois.

\subsubsection{Neutron Kerma Scanning}

A Cartesian coordinate system has been established for the exposure room. Since the reactor face is curved, the opposing wall was chosen as the base plane. The line that is normal to the reactor face at its center forms the $z$-axis and intersects the wall at $(0,0,0)$. The $y$-axis is vertical, with the floor at $y=-96 \mathrm{~cm}$, and the $x$-axis is horizontal. Thus, persons standing at the rear wall and looking at the reactor face see the face as they would a graph with vertical $y$ and horizontal $x$.

Measurements made with the acetylene and argon ionization chambers at the reference location $x=-3, y=0, z=100 \mathrm{~cm}$, with the reactor at $200 \mathrm{~kW}$ and without the attenuator, gave a fast-neutron kerma rate of $23 \times 10^{2} \mathrm{erg} / \mathrm{g} \cdot \mathrm{min}$ with a $\gamma$-ray component of less than $3 \%$. The addition of 456 phantom mice reduces the fast-neutron kerma rate by about $2 \%$, while the $\gamma$-ray component maintains the same ratio.

The room was scanned at 50-cm intervals in $x$ and $z$ and at $25-\mathrm{cm}$ intervals in $y$ from -75 to $+75 \mathrm{~cm}$. The measurement technique was modified by adding a third electrometer connected to a Shonka tissueequivalent ionization chamber used as a monitor. Data were obtained at 275 room locations.

These data are used to calculate the neutron and $\gamma$-ray kerma ratios (as a percentage of that at the reference location) for each mouse in a load frame at a specified room location and angle to the $x$-axis. A range of shelf positions to be used may be specified, and the average kerma ratio and individual deviations from the average can be calculated over this range of shelves.

Figure 4 shows one room layout with isodose contours corresponding to the height of mice in shelves about $100 \mathrm{~cm}$ above the floor. 


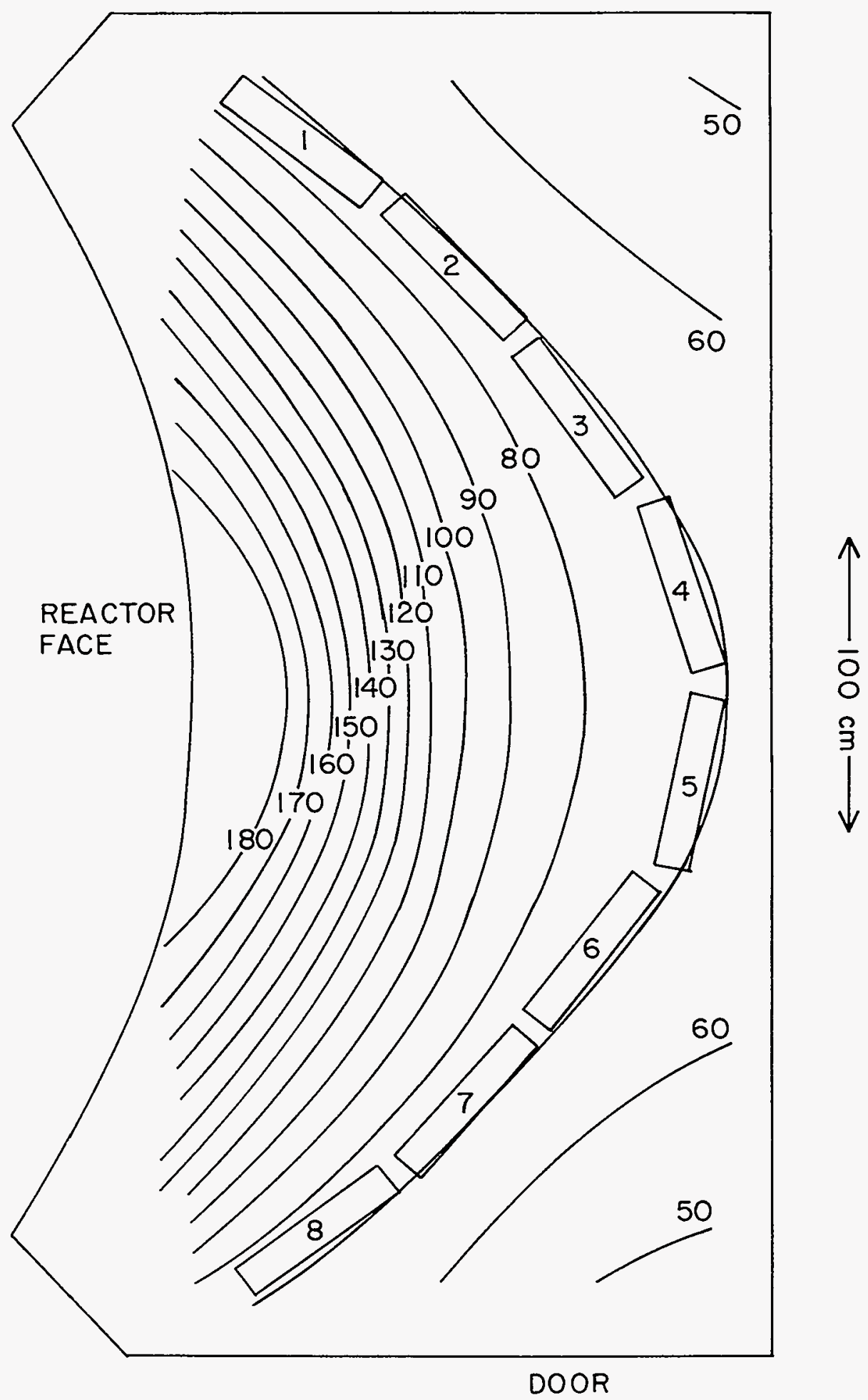

FIGURE 4 Plan View of JANUS High-Flux Room Showing Isodose Contours. Eight load frames are indicated on one contour line (see text for details). 
The contours are in percentages of kerma at the reference location with the attenuator in use. This loading layout, with use of 10 shelves per frame as seen in Figure 3, has a worst-case deviation from average of $-9.7 \%$ in the top and bottom shelves of frames 1 and 8 for the individual animal locations closest to the reactor face (1\% of the animal loading). The animals are placed at random in the loading frame to compensate for these deviations in dose, and the positions are monitored by the computer so that individual animal accumulated doses can be calculated.

\subsubsection{Thermal-Neutron Contribution}

Measurements with gold foils at the standard reference location, for $200 \mathrm{~kW}$ with no attenuator, show a thermal flux (under cadmium) of approximately $1.72 \times 10^{6} \mathrm{n} / \mathrm{cm}^{2} \cdot \mathrm{s}$, which corresponds to a kerma rate (due to $\mathrm{N}[\mathrm{n}, \mathrm{p}]$ reactions only) of less than $0.02 \%$ of the fast-neutron kerma rate. A full load of 400 mouse phantoms approximately doubles the thermalneutron flux and contribution. In most neutron facilities, the thermalneutron flux is greater than that of other energy groups below $10 \mathrm{keV}$, but in the JANUS high-flux room, the walls act as thermal-neutron sinks so that this flux is depressed below the level of any other energy group. Since measurements of absorbed dose will always be made with tissue-equivalent devices, the contribution from thermal neutrons will be included.

\subsubsection{Neutron Spectrometry}

Spectra were taken at five locations in the JANUS high-flux room, identified by the $x, y, z$ coordinates as $\mathrm{A}$, in the center of the room at $(0,0,100) ; B$, at the converter lead wall $(0,0,184) ; C$, at the rear lead wall $(0,0,5) ; D$, near the unleaded room door $(-129,0,50)$; and $\mathrm{E}$, in the completely leaded corner opposite the door at $(216,0,50)$. Effective reactor power levels were monitored over the range $100 \mathrm{~W}$ to $200 \mathrm{~kW}$ with a series of overlapping ${ }^{3} \mathrm{He}$ and ${ }^{235} \mathrm{U}$ counters, and all spectra were normalized to the reactor $200-\mathrm{kW}$ level.

Spectra obtained at the central point, A, are shown in Figure 5. The proton-recoil spectrum obtained by Bennett and Yule (1972) at the same point and corrected for end and wall effects is shown for comparison. All spectra are given in absolute units and are completely independent of each other. 
The arithmetic-mean neutron energy and kerma rate at the five room locations are as follows:

\begin{tabular}{ccc}
$\begin{array}{c}\text { Room } \\
\text { Position }\end{array}$ & $\begin{array}{c}\text { Mean } \\
\text { Energy } \\
(\mathrm{MeV})\end{array}$ & $\begin{array}{c}\text { Kerma Rate at 200 kW } \\
(\mathrm{erg} / \mathrm{g} \cdot \mathrm{min})\end{array}$ \\
\hline A & 0.855 & $20.4 \times 10^{2}$ \\
B & 1.140 & $51.1 \times 10^{2}$ \\
C & 0.716 & $14.4 \times 10^{2}$ \\
D & 0.562 & $8.9 \times 10^{2}$ \\
E & 0.646 & $10.2 \times 10^{2}$ \\
\hline
\end{tabular}

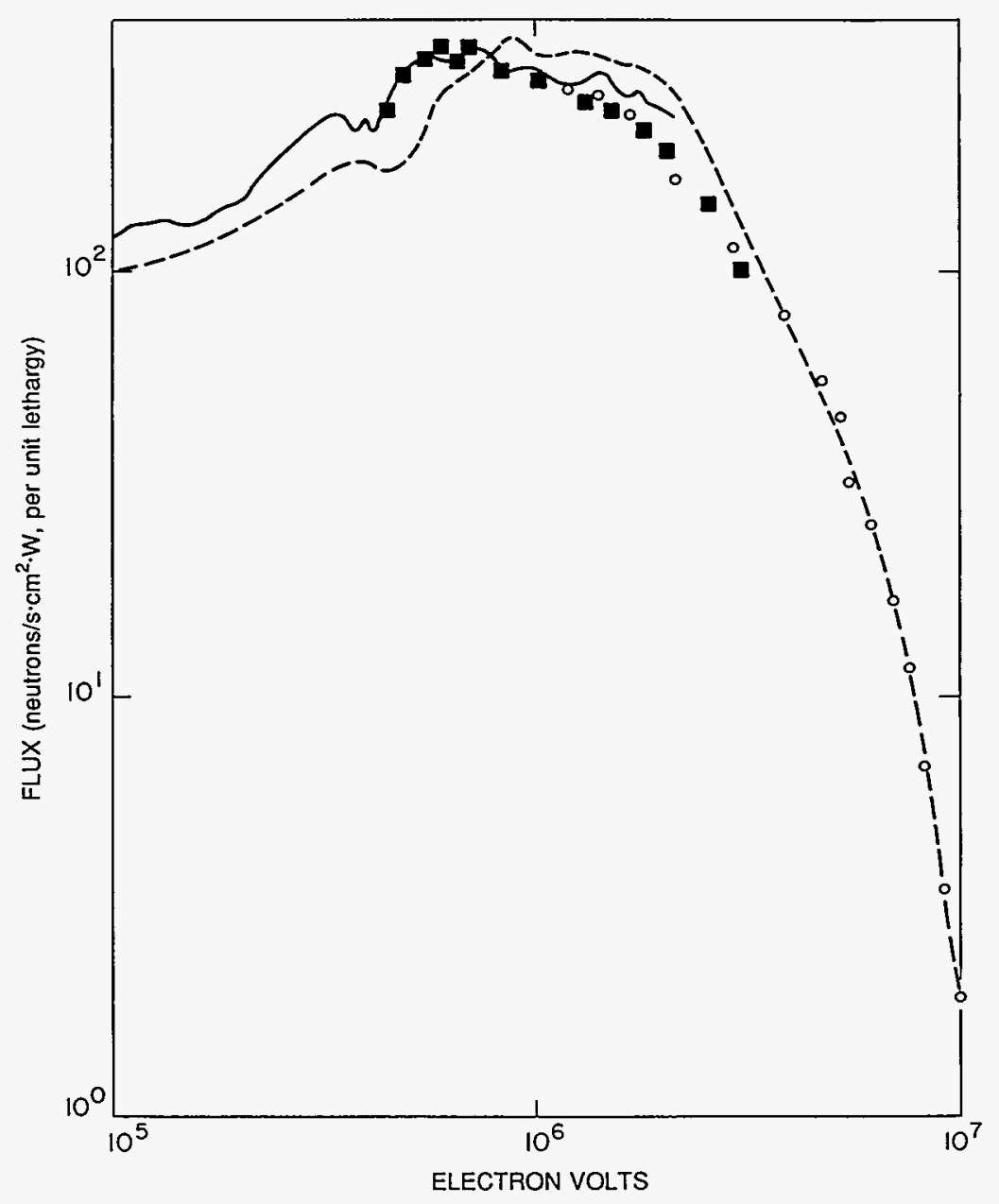

FIGURE 5 Neutron Energy Spectra in the High-Flux Room. Solid line, proton recoil and/or ${ }^{3} \mathrm{He}$ spectra; squares, with ${ }^{6} \mathrm{Li}$ spectrometer; circles, with activation foils; dashed line, predicted spectrum 
The spectrum-derived kerma rates are in excellent agreement with the ionization chamber measurements.

A more complete spectrum, taken from Williamson and Frigerio (1972) and given in terms of kerma rate vs. neutron energy, is presented in Figure 6. The influence of neutron scattering on the energy spectrum can be clearly identified.

\subsection{GAMIMA IRRADIATIONS}

With few exceptions, all neutron irradiations were matched with $\gamma$ irradiations to develop the data needed to calculate $\mathrm{RBE}$ values for diverse somatic and genetic endpoints. All $\gamma$ irradiations (except for experiments JM-4L1 and JM-4L2) were done with ${ }^{60}$ Co sources in the HLGF located near the reactor.

The service floor of ANL Building 202, located approximately $18 \mathrm{ft}(5.5 \mathrm{~m})$ below ground level, contains both the HLGF and the JANUS high-flux exposure facility. Entrances to the two facilities are about $36 \mathrm{ft}(10.9 \mathrm{~m})$ apart and open on a common $5-\mathrm{ft}(1.5-\mathrm{m})$ corridor. The two exposure facilities, the corridor, and the preparation and control areas share a common environment in terms of heating and ventilation, though the high-flux room itself is ventilated through a closed and monitored pathway.

The exposure room of the HLGF is $23 \times 23 \times 18 \mathrm{ft}(6.7 \times 6.7 \times 5.5 \mathrm{~m})$, and access is through a double- $\mathrm{L}$ maze, entrance to which is electromechanically controlled. The walls and ceiling are $2 \mathrm{ft}(0.6 \mathrm{~m})$ thick except for the wall facing the control console, which is $4 \mathrm{ft}$ $(1.2 \mathrm{~m})$ thick. A standard commercial unit, a Gammabeam 650 Irradiator, built and installed in April 1973 by Atomic Energy of Canada Limited, is located in the center of the room. The unit has 12 stainless steel source tubes, each containing three encapsulated ${ }^{60}$ Co sources, the active portion of which is approximately $1 \times 0.5 \mathrm{in} .(2.5 \times 1.3 \mathrm{~cm})$. The unit can use a single

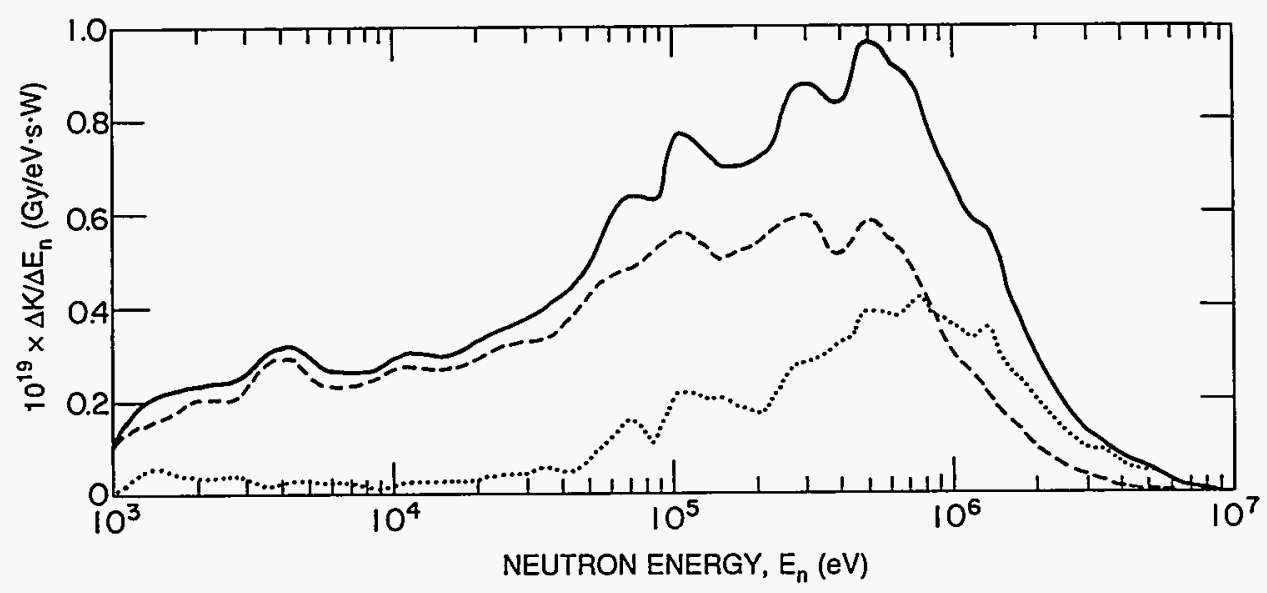

FIGURE 6 Neutron Energy Spectra in the High-Flux Room, from Williamson and Frigerio (1972). Dotted line, at face of converter plate; dashed line, at lead wall opposite face; solid line, sum of separate spectral measurements 
source tube or any number and combination of tubes up to the full 12 tubes. The many source configurations available permit exposures at a 1-m distance that range from about 20 to $30,000 \mathrm{R} / \mathrm{h}$. Curiages (the radioactivity in curies at the sources) range between 18 and 5000 . Mean source height above the floor is 68 in. $(172.7 \mathrm{~cm})$. The source storage cask rests on the floor and is $50 \mathrm{in} .(127 \mathrm{~cm})$ tall and $35 \mathrm{in} .(88.9 \mathrm{~cm})$ in diameter. Therefore, the exposed sources are only $18 \mathrm{in} .(45.7 \mathrm{~cm})$ above the cask.

Field dosimetry in the HLGF uses a Victoreen Model 415 chamber. As in the JANUS high-flux room, a given dose rate measured from a fixed source forms a doubly concave isodose surface or contour. The curvature is obviously more prominent in the HLGF because of the point source compared with the broad exposure face of JANUS. Within a single exposure frame hanging vertically in the contour, the worst-case deviations from the average are about $-12 \%$ at $1.3 \mathrm{~m}$ from the source and $-5.5 \%$ at $2.2 \mathrm{~m}$. These deviations occur in the top and bottom shelves in the 10-shelf exposure frame (see Figure 3). For a multipleexposure series, the deviations are averaged out by a computer-managed randomization of the location for each mouse as it is repeatedly exposed. For single exposures, the irradiation procedure avoided loading animals in the extreme locations of the frames.

The Gammabeam 650 was used for all experiments described in this report except for the first, JM-2, and for the two low-dose-rate studies, JM-4L1 and JM-4L2. The irradiations for JM-2 were carried out between March 1971 and June 1972 and used the original sources and source-handling mechanisms installed in the HLGF in 1954 and 1958. Those sources were 12 -in. $(30.5-\mathrm{cm})$ linear ${ }^{60} \mathrm{Co}$ rods encapsulated in stainless steel and held about 48 in. $(121.9 \mathrm{~cm})$ above the floor (the source storage cask was in the floor). The original HLGF was constructed as part of the original Building 202 in 1950-1952, along with the low-level facility described by Grahn et al. (1994) in the pre-JANUS archive document for the 1953-1970 period. At the time, they were unique among AEC facilities, though, in retrospect, they were little more than large concrete pillboxes. The original source-handling mechanisms were designed, built, and installed by the then-existing Remote Control Engineering Division at ANL.

\subsection{DEPTH-DOSE ESTMMATES}

A critical factor in the development of data that can be used for accurate comparisons of the effects of neutrons vs. $\gamma$ rays concerns the dose terms. Obviously, the two radiations, fission neutrons and ${ }^{60} \mathrm{Co} \gamma$ rays, had to be "normalized" before comparisons could be made. Normalization was achieved by making the dose term a tissue dose, specifically, the midline tissue dose for the mouse. Unfortunately, the dosimetric procedures and results have never been presented in complete form in a single report; however, much information can be gleaned from Grahn et al. (1972), Williamson and Frigerio (1972), Williamson et al. (1971, 1972, 1973), Borak and Stinchcomb (1979), and Marshall and Williamson (1985). A brief description of the results of the depth-dose studies is presented here.

A 30-g "muromorphic" mouse, having dimensions of $5 \times 3 \times 2 \mathrm{~cm}$ and made of a tissue-equivalent plastic known as Shonka A150, was used for the studies. Dr. F.R. Shonka, 
of Illinois Benedictine College, developed the tissue-equivalent plastic and also constructed a pair of $0.05-\mathrm{mL}$ ionization chambers to be used in the tissue-equivalent mouse. The elemental composition of the A150 plastic, in terms of percent by weight, was as follows: $\mathrm{H}=10.25, \mathrm{C}=77.28, \mathrm{~N}=3.49, \mathrm{O}=3.99, \mathrm{~F}=2.43$, and $\mathrm{Ca}=2.57$.

Two 0.05-mL chambers were used to measure doses at the approximate center of the phantom. One chamber was made of tissue-equivalent material; the other was of magnesium and was filled with argon. Measurements of dose were made with the phantom at five different orientations to the $\gamma$-ray source or to the reactor face: $0^{\circ}$ (nose to the source), $45^{\circ}$, $90^{\circ}, 135^{\circ}$, and $180^{\circ}$ (tail to the source). Measurements were also made without the phantom. The average midline neutron dose in rads was $80 \%$ of the neutron kerma "in air." For $\gamma$ radiation, the midline dose was $90 \%$ of the measured roentgens "in air." Specifically, for $\gamma$ rays, the ratios were $0.96 \mathrm{~K} / \mathrm{R}$ and 0.934 midline tissue dose $\mathrm{rad} / K(0.96 \times 0.934=0.897)$. The delivered doses in the JM studies were the calculated midline tissue dose values measured in rads (0.01 Gy). Details can be found in Grahn et al. (1972), Williamson and Frigerio (1972), Williamson et al. (1972), and ICRU Report 30 (1979). Because all delivered doses were midline tissue doses, dose-response coefficients in terms of response per rad of $\gamma$ rays or neutrons can be directly applied to the estimation of RBE values or other measures of fission-neutron effectiveness when compared with responses to ${ }^{60} \mathrm{Co} \gamma$ rays. 


\section{EXPERIMENTAL PROCEDURES}

\subsection{ANIMAL HUSBANDRY AND HOUSING}

\subsubsection{Animal Source and Supply}

\subsubsection{Mus musculus}

All of the $\mathrm{JM}$ series studies used the $\mathrm{B}_{6 \mathrm{CF}}$ mouse, the $\mathrm{F}_{1}$ from the cross of $\mathrm{C57BL} / 6$ females with $\mathrm{BALB} / \mathrm{c}$ males. The parent inbreds were originally obtained from the Jackson Laboratory, Bar Harbor, Maine, in 1953 (Grahn et al. 1994) and were maintained by full-sib matings as conventional stocks. In 1965, breeding stock from the two strains were given to the ANL animal facilities staff, under R.J. Flynn, DVM, to produce a germ-free breeding stock from which specific pathogen-free (SPF) strains could be derived for the production of large numbers of $\mathrm{B} 6 \mathrm{CF}_{1}$ mice for the JANUS program. The correct designations for these SPF parent strains are BALB/c ANL (ANL 66) and C57BL/6/ANL (ANL 66). The "(ANL 66)" designates the institution of origin and the year when the SPF status was obtained. The inbred strains were rederived in 1970, so some records will note B6CF 1 ANL (ANL 70), others $\mathrm{B}_{6 \mathrm{CF}} / \mathrm{ANL}$ (ANL 66). This is not a critical difference. The strain is numerically coded as 08, following from its original designation in 1954 (Grahn et al. 1994).

The SPF status was periodically checked by the animal facilities staff and by commercial laboratories. No unusual or unacceptable microbiological or virological deviations from the SPF status were noted over the years. All mice were vaccinated for ectromelia (mouse pox) before entry into an experiment.

Animals were weaned into large cages with dimensions of approximately $16 \times 8 \times 5$ in. $(40.6 \times 20.3 \times 12.7 \mathrm{~cm}$, length by width by height), 15 or 20 to the cage. At $110 \pm 5 \mathrm{~d}$ of age, the mice were recaged into small plastic cages of $11 \times 7 \times 5 \mathrm{in}$. $(27.9 \times 17.8 \times 12.7 \mathrm{~cm})$, five per cage. These cages were then randomly assigned to their ultimate experimental status and to holding rooms in the animal facilities.

\subsubsection{Peromyscus leucopus}

In 1963, G. Sacher and E. Staffeldt trapped wild Peromyscus leucopus (the white-footed deer mouse) on the Argonne site and established a breeding colony in the animal facilities. Additional breeders were periodically captured in the wild. The colony was maintained by random outcross matings, and conventional caging and husbandry methods were employed. Though G. Sacher performed a number of radiobiological and gerontological studies with $P$. leucopus and other small mammals taken from the wild, $P$. leucopus was selected for use in the JANUS program for one major study (JM-10). This study compared responses to single and fractionated neutron and $\gamma$-ray exposures with those seen in the $\mathrm{B} 6 \mathrm{CF}_{1}$ subjected to the same exposure regimes. $P$. leucopus is slightly larger than the $\mathrm{B} 6 \mathrm{CF}_{1}$ 
mouse, ranging from 20 to $45 \mathrm{~g}$ at about $140 \mathrm{~d}$ of age when they were entered into the study. Their life expectancy from birth is about $1450 \mathrm{~d}$ (Sacher and Hart 1978), which is about 50\% greater than that of the $\mathrm{B}_{6} \mathrm{CF}_{1}$ mouse.

\subsubsection{Housing}

A critical lesson that was learned in the early studies (Grahn et al. 1994) concerned the importance of maintaining both experimental and control animals in a common environment. In the JANUS studies, this was accomplished by keeping all mice in a common home environment or animal rooms except when actual irradiations were performed. All controls, with one exception (JM-7), were sham-irradiated in the corridor of the service floor between the HLGF and the reactor. As previously noted, all mice were housed in a clear plastic cage, five per cage. The stainless steel cage top was screened in the back half and held a water bottle and food bin in the front half. Originally, a corncob bedding was used, but it was found to carry the organism Enterobacter cloacae, which caused an acute intestinal syndrome. Sterilized wood chip shavings were thereafter consistently used for cage bedding.

Room management and housing assignments were made by a computer-generated procedure. Cages were located (according to experiment) in home rooms and positioned on a random basis with respect to radiation quality (including control), sex, treatment dose and exposure pattern, replication number, and cage number. The animals in every experiment were always located (housed) in two or more separate animal rooms to minimize any effects due to differential room environment.

\subsubsection{Animal Husbandry}

Routine animal care was the responsibility of the animal facilities staff and was carried out by trained and experienced animal care specialists. Periodic sampling of food, water, feces, etc. for infectious organisms was performed by the scientific staff of the animal facilities. During the period that the JANUS studies were being carried out, the ANL animal facilities were fully accredited by the American Association for the Accreditation of Laboratory Animal Care.

Cages would normally be changed weekly but more frequently if conditions required. Water bottles were changed twice weekly, and the water was acidified to $\mathrm{pH} 2.5 \pm 0.1$ with $0.1 \mathrm{~N} \mathrm{HCl}$. This successfully eliminated water-borne infection by Pseudomonas aeruginosa. Acidified water did not otherwise influence the health status of the mice. Food was always available and was normally Wayne Mouse Lab Blox. All rooms and cages were checked every day $(7 \mathrm{~d} / \mathrm{wk})$.

The animal rooms were maintained at $73 \pm 3{ }^{\circ} \mathrm{F}\left(22.8 \pm 1.7^{\circ} \mathrm{C}\right)$ and humidity at $50 \pm 5 \%$. Filtered and conditioned air was turned over between 10 and 15 times per hour and was exhausted into the corridors of the animal facilities. Animal holding rooms were at a positive air pressure compared with that of the hallways. There were no windows in the 
animal facilities, and a 12-h light/dark cycle was maintained with electric timers; the light period was from 6 AM to 6 PM.

\subsection{IRRADIATION PROCEDURES}

Special exposure frames were used for all irradiations. These were constructed of a magnesium-aluminum alloy (to minimize neutron activation) and had dimensions of about $5 \mathrm{ft}(1.5 \mathrm{~m})$ in height by $2 \mathrm{ft}(0.6 \mathrm{~m})$ in width. They were suspended from ceiling hangers in the JANUS high-flux room (Figure 3) and from portable floor stanchions in the HLGF. A frame could hold up to 12 shelves (10 were normally used), each suspending five 1-pt (0.5-L) polyethylene cups in a row, each cup holding one mouse. Missing mice were replaced by a tissue-equivalent dummy. Because the frames occupy a vertical space in a nonlinear isodose contour, only those shelves were used for a given exposure where the deviation from mean dose would be less than $10 \%$.

The frames were loaded by the animal care specialists, according to computer-generated loading instructions. Each frame contained mice to be located in a single dose group, although several frames could be used for each dose. Cages to be loaded were identified by the animal identification code and the cage location in the holding room. Shamirradiated controls were handled exactly as the mice to be irradiated, but their frames were hung in the hallway outside the JANUS and HLGF rooms. After irradiation, frames were unloaded in the home rooms by the animal care specialists according to computer-generated instructions.

Long-term exposures $(22 \mathrm{~h} / \mathrm{d})$ in the low-level $\gamma$-ray facility, used only for experiments JM-4L1 and JM-4L2, employed the same frame, basic shelf unit and 1-pt (0.5-L) cups, but the units were modified to hold a 5-oz (0.15-L) plastic water bottle and a springloaded vertical feeder unit behind the bottle. Wood chip litter was provided for the individual mouse in each cup. Mice remained in this housing unit for $5 \mathrm{~d}$ of each week of exposure, Monday morning to Saturday morning. The other $2 \mathrm{~d}$ were spent in the standard home cage, five mice per cage. Controls and irradiated mice were handled in the same manner, with the controls remaining in the corridor of the facility entrance maze.

We emphasize that for all of these exposure procedures, computer programs managed all operations and randomized all cage loadings per dose, sex, and radiation quality, for each replication within the specific dose contour, so that all deviations from mean delivered dose would be randomly distributed among all mice within the dose group. The computerized randomization process that managed all irradiations and housing locations is the manifestation of the policy to minimize, or even eliminate, any environmental or irradiation heterogeneity that might confound response variables or challenge the credibility of any finding. 


\subsection{POST-IRRADIATION FOLLOW-UP PROTOCOLS}

\subsubsection{Death Checks}

Throughout the JM experimental series, mice were usually relocated within the animal facility after their irradiations were completed. This facilitated the death checks that were performed daily, $7 \mathrm{~d} / \mathrm{wk}$, including holidays. On regular work days, members of the program staff performed the checks, usually twice daily. The afternoon check would identify moribund animals that were expected to die overnight. Moribund mice were euthanized with ether. On weekends and most holidays, death checks were performed once daily by animal care specialists who were experienced in this procedure.

A dead animal was removed from the cage and placed in a disposal bag, and a JANUS death tag was stapled to the bag. A sample copy of the death tag and a copy of a cage card, from which the essential identification data were taken, are seen in Appendix A. The cage card contained all information pertaining to the identification and location of the dead mouse. The animal identification code included the radiation quality ( $C$, control; $\mathrm{G}, \gamma$ ray; $N$, neutron); the sex (M, male; $F$, female); treatment group, which is usually a dose code; replication number; and cage number. This provides an eight-character alpha-numeric code for the identifying "family name." The number of animals in a cage ranged from 1 to 5 . The individual animals were not preidentified. Numbering was based on which died first, second, . . . fifth; number 1 was the first recorded and number 5 the last. This individual number gave a "first name" to each animal, and thus, the nine characters provided each animal with an unique identification. The death tag was filled out with the appropriate information from the cage card that identifies the experiment, animal identification code, date of death, etc. The date of death was entered on the cage card and the card was returned to the cage. The dead animal was either refrigerated or taken directly to the necropsy prosector. According to the condition of the animal, the prosector determined if a necropsy should be done. Ultimately, an exit code and an autopsy code were assigned to the individual identified on the death tag, and the codes were entered along with the date of autopsy and the initials of the prosector. The exit codes and autopsy codes are defined in Appendix B.

\subsubsection{Pathology Protocols}

\subsubsection{Necropsy Procedure}

The necropsy report (Appendix C) is made up of three pages: page 1, coded MACRO observations; page 2, a carbon copy of the top of page 1 that was used to enter the MACRO data into the computer; and page 3, coded MICRO diagnoses. The first page was filled out as the necropsy was performed. The data from the JANUS death tag were transferred to the necropsy report, and the death tag number (upper right corner) became the autopsy number. As the necropsy progressed, sketches of lesions and tumors were placed on 
the drawings of the mouse, observations were circled, and the tissues fixed were indicated in the appropriate boxes at the bottom of the page.

The necropsy protocol, presented in detail in Appendix D, specifies the gross characteristics to be identified or sought out for all organs and tissues by the prosector. It also describes the specific appearances of organs and tissues that are directly defined by specific gross pathology codes. The full MACRO dictionary of three-letter nontumor and fourletter tumor codes is given in Appendix $\mathrm{E}$ in alphabetical order. Part 6 of Appendix D discusses the criteria to be considered for establishing a probable cause of death on the basis of the gross findings. The probable cause of death was entered on the necropsy report. In addition, the presence or absence of a tumor was indicated as $\mathrm{T}$ or NT, and MACRO diagnoses were recorded as tumor or nontumor codes. After the necropsy was completed, the second page of the necropsy report was removed and used to enter the gross pathology into the computer MACRO records for the experiment.

\subsubsection{Collection of Tissues and Preparation for Histopathology}

Tissue sampling for histopathology followed a standard procedure throughout the JM series. In some studies, selected additional tissues might have been taken for special purposes, but the procedure outlined in Appendix F can be considered the basic protocol. The procedure for fixing, staining, and mounting the tissues on slides is outlined in Appendix G. Obviously, not all tissues or organs were routinely sampled, other than those listed, and no effort was made to detect occult tumors or other lesions that were considered to be noncontributory to the animal's death. As stated in the original description of the JANUS program in 1972 (Grahn et al. 1972), the intention was always "to ascertain the cause of death to as high a degree of accuracy as practicable." We were concerned, as well, with all major contributory and noncontributory pathology. Although funding and manpower limitations forced some compromise, nevertheless about $93 \%$ of all deaths did have an accompanying gross pathology. The majority of the necropsies were performed by only four prosectors, which ensured a high degree of consistency in the gross diagnoses. Of all the animals examined for gross pathology, only about $49 \%$ subsequently had a histopathologic examination, and this proportion varied among the studies (see Section 3).

\subsubsection{Histopathology Codes}

As the pathologist read the slides, the diagnoses were recorded and coded on the bottom of the first page of the necropsy report. The MICRO dictionary of the four-letter histopathology codes is given in Appendix $\mathrm{H}$.

All histopathological findings were classified as either lethal (L), contributory (C), or noncontributory $(\mathrm{N})$. These findings may or may not have confirmed the decision made on the gross findings. The coded diagnoses were transferred to the third page of the necropsy report. This coded information was entered into the computer MICRO records for the experiments. 
Histopathology was performed by several pathologists over the years. L.S. Lombard, a board-certified veterinary pathologist, was involved throughout the JANUS series, except for JM-14, and she performed the majority of the histopathological evaluations. Dr. Lombard died in 1987.

J.H. Rust, DVM, carried out many evaluations for the earliest studies, such as JM-2, -3, and -4. R.J.M. Fry also performed both gross and histopathological evaluations in the early years of the programs, before he took a position at the Oak Ridge National Laboratory in late 1977.

In the MICRO Dictionary (Appendix $\mathrm{H}$ ), the content and codes were jointly developed by Drs. Fry, Lombard, and Rust. One might say the dictionary was developed iteratively during the late 1960s and early 1970s, and it reflects the cumulative experience of the three pathologists plus the pragmatic need to codify the principal pathology seen in the mouse in a reasonably simple and descriptive manner.

\subsection{RECORD KEEPING AND DATA MANAGEMENT}

Computerized record keeping and data management reached a high level of development for the JANUS program. This capability evolved over the many years preceding the program; in a sense, it started with the earliest studies in the 1940s. It resulted from the fortunate confluence of skills, needs, and opportunities. The capability reached its highest form in the JANUS program, and it is being used as a role model for other DOE animal research programs. In 1988, the JANUS database was transferred from the ANL IBM mainframe to the ORACLE relational database management system. The use of ORACLE has permitted the JANUS data to be articulated with other ORACLE databases, such as that from the studies at ANL with the beagle.

The ORACLE system is organized into tables that contain all the information necessary to initiate experiments, to enter experimental data, or to be used in data analysis. Appendix I contains a list of the ORACLE tables and the definition of the fields in each table. Tables GENERAL, EXIT, FRACTIONS, MACBASE, MACFIND, MICBASE, and MICFIND contain all of the data for JM-2 through JM-14. The other tables are used in the initiation of new experiments. The computer-managed aspects of the JANUS experiments and data analysis are set into operation by the use of menu selections. These menu items are primarily for experimental setup, data entry, and data analysis, but with a little instruction, the database may be queried directly.

\subsubsection{Data Entry}

The hard-copy records and codes presented in Appendices A, B, C, E, and $\mathrm{H}$ were used for data entry as described in Sections 2.2 and 2.3. The data were routinely entered into the appropriate tables by use of the menu. As every individual mouse was uniquely coded for experiment, radiation quality, sex, treatment, replicate number, cage number, and 
individual number, entries into the database were internally controlled against random error. Nevertheless, all entries were subject to a quality control follow-up performed by a second party who was not involved in the original entry.

\subsubsection{Specialized Data Organization}

For special applications, data from the tables may be merged for analysis. It is also necessary to have the radiation protocol codes for each experiment in the JANUS series available for use in a separate file (Appendix $J$ ). Users can thus select data for analysis by any array of codes for experiment, radiation quality, sex, and dose. Additional data may be extracted into separate files for special use.

The MACRO and MICRO codes have been grouped into MACRO and MICRO combined pathology glossaries (Appendices $\mathrm{K}, \mathrm{L}$, and $\mathrm{M}$ ). These glossaries are used in analyses of the occurrence of pathological conditions. To compare the incidence of different diagnoses, there is a need to group similar diagnoses. Grouping similar findings can increase numbers as some individual diagnoses are not very plentiful and therefore not significant. Each of the combined pathology glossaries $\langle\mathrm{E}\rangle,\langle\mathrm{F}\rangle$, and $\langle\mathrm{H}\rangle$ comprises 28 groups of definite composition: a group may be composed of 1) cause of death undetermined, 2) tumors or nontumors, 3) primary or secondary (metastatic) tumors, 4) like tumor types, 5) individual tumor type, 6) tumors of like tissue type, 7) tumors of specific organs or organ systems, 8) metastatic tumors, 9) metastatic tumors of specific sites or of specific origin, 10) nontumors, or 11) nontumors of specific organs or organ systems. Glossaries $<E>,<F>$, and $<\mathrm{H}>$ may have some groups in common but for the most part are different.

Glossary $<\mathrm{E}>$ contains all the possible codes in the dictionaries divided into the 28 groups: 3 major classes of connective tissue tumors, 13 classes of epithelial tissue tumors, 4 classes of secondary tumor occurrences, 7 classes of non-neoplastic disease, and 1 class of undetermined cause of death. One important use for this glossary, made possible by the singularity of each code, is in the analysis of concordance and discordance between gross and microscopic pathology. The specific contents of $\langle\mathrm{E}\rangle$ are found in Table 1 (tables begin on p. 43) and Appendix K.

Glossary $\langle\mathrm{F}\rangle$ regroups some components and subdivides others found in $\langle\mathrm{E}\rangle$. This glossary contains only tumor diagnoses, as over $75 \%$ of the cause-of-death diagnoses are a neoplasm. The contents of $<F>$ are listed in Table 2 and Appendix $L$.

The third combined pathology glossary $<\mathrm{H}>$ (Table 3 and Appendix M) contains some groups repeated from $<F>$ but has separated some classes of lymphoreticular tumors, connective and epithelial tissue tumors, and selected metastatic tumors in order to make more detailed comparisons of these diagnoses.

The use of the glossaries allows for the creation of a combined pathology database for each of the JANUS experiments. The combined pathology database contains each individual mouse scored for the occurrence of a diagnostic code found within the 28 groups. 
A different database may be constructed for MACRO and MICRO diagnoses found for Glossaries $\langle\mathrm{E}\rangle,\langle\mathrm{F}\rangle$, and $\langle\mathrm{H}\rangle$. These databases are used in conjunction with the JANUS radiation protocol (Appendix $J$ ) in many of the analysis procedures.

\subsubsection{Reliability and Potential Use of the Pathology Data}

A summary of the $13 \mathrm{JM}$ series studies, which will be described in detail in Section 3, is presented in Table 4. This table provides the total numbers in the three major categories of death records, gross pathology records, and histopathology records. Between 90\% and $98 \%$ of all death records have an accompanying gross pathology record, while between $0 \%$ and $85 \%$ of the gross records have an accompanying histopathology record. Obviously, the gross pathology data have both uniformly and adequately sampled the death records. The reliability (and, therefore, the usability) of the gross pathology records becomes an important consideration for any comparative analysis.

The issue of reliability and consistency of the pathology data, as the data accrued over the years, escaped neither our attention nor the attention of outside reviewers. An independent audit of the gross and microscopic pathology records was therefore contracted and was performed by Pathology Associates, Inc., of Frederick, Maryland, in 1986. The complete radiation, death, autopsy, and pathology records were randomly selected for about $50 \%$ of the animals from the data for two experiments, JM-4K and JM-13. The results of the audit confirmed the consistency and repeatability of the gross diagnoses and of the judgments on the causes of death made by the prosectors. The pathologists performing the audit concurred with the gross and microscopic diagnoses in over $90 \%$ of the cases examined. This was considered an excellent level of agreement, and the auditors also acknowledged that some of the differences in opinion on cause of death were equivocal.

\subsubsection{Analysis of Concordance between the Gross and Microscopic Pathology}

As a consequence of the audit's findings, we established the principle that the histopathological findings could be held as the ultimate truth and used, therefore, to test quantitatively the level of concordance or agreement between the gross and microscopic pathology. As noted in previous sections, the gross pathology record always suggested a "cause of death," a lethal (L) tumor or other lesion, including an undetermined cause (CDU). The histopathology classified each finding as either lethal (L), contributory (C), or noncontributory $(\mathrm{N})$. By grouping the histopathological findings as either lethal $(\mathrm{L})$ or lethal plus contributory (LC), comparisons can be made with the gross finding of $L$ to determine the accuracy of that original judgment. The comparison of the two $L$ classes is straightforward. The test of gross L against histopathology LC broadens the basis of comparison and recognizes realistically that the gross finding has limitations that are somewhat alleviated by including the histopathologically defined lesions that are clearly contributory to the animal's death. 
The concordance test for all observed pathology, that is, all observed gross diagnoses vs. all observed microscopic diagnoses (lethal plus contributory plus noncontributory, LCN), is essentially a test of the thoroughness and accuracy of the observations made by the prosectors at necropsy. It is not a test of judgment of the severity of a lesion, but rather, on its presence.

A summary of concordance analyses for a portion of the JM series (JM-2, -3, $-4 \mathrm{~K}$, $-4 \mathrm{~L} 1,-4 \mathrm{~L} 2$, and -9 ) is given in Table 5 for selected single and grouped endpoints from pathology glossaries $\langle\mathrm{E}\rangle$ and $\langle\mathrm{F}\rangle$. About 13,400 matched records are included in this summary. The level of concordance (percentage of gross diagnoses confirmed by histopathology) is presented for the three categories of L, LC, and LCN. Only tumor-related deaths and tumor occurrences were analyzed because these account for over $75 \%$ of all terminal pathology and causes of death.

Table 5 reveals that, at best, only seven gross pathology categories could be consistently used, on the assumption that the concordance rate should be $85 \%$ or greater. These categories are the underlined values in the table, and the best array is that under the LC column. In other words, a less rigid definition of cause of death that includes contributory lesions provides a good cross section of pathologies: three connective tissue groups, three epithelial tissue groups, and the all-inclusive class of "all primary tumors." The inclusion of tumors of the Harderian gland is of special note because this tumor is highly responsive to neutron exposure.

The all-observed-pathology analysis (LCN) does not materially improve the concordance rates, though many of the pathology groups do have significantly increased sample sizes. That fact, in turn, should improve statistical factors.

\subsubsection{Analysis of the Discordance between the Gross and Microscopic Pathology}

The test for discordance is an analysis of errors of judgment regarding the presumed cause of death defined by the prosector. This analysis can only be done for the lethal category with pathology glossary $\langle E\rangle$ for both gross and microscopic pathology, because the analysis requires a nonconflicting matching pair of diagnoses for each animal. The animal can only be represented by a single diagnosis for the gross and for the microscopic pathology. Multiple entries per mouse, as for the LC category, confuse the computer. In spite of limitations, the discordance analysis allows detection of patterns of error in the gross pathology that can be valuable in the interpretation of any analysis of the gross findings.

Although the analysis runs the full $28 \times 28$ matrix, not all cells in the matrix have entries, and many have sample sizes too small to give useful information. Table 6 presents a selected $7 \times 7$ matrix involving diagnoses that not only have adequate sampling but also produce information that reveals the nature or pattern of diagnostic errors. Simply stated, the errors are not random. 
The undetermined cause category (CDU) is large, and the majority of discordant diagnoses became reclassified as lymphoreticular tumors. This latter class has a very small discordance rate, and most of these go to the CDU class. For the most part, misdiagnoses among connective tissue tumors are reclassified within that general category. On the other hand, errors among the epithelial tissue tumors (lung, liver, and ovarian tumors) are predominantly reclassified after microscopic study into the connective tissue diagnoses, mostly as lymphoreticular tumors. The reader should note that liver tumors have a high rate of discordance (about 50\%) and nearly two-thirds become reclassified as lymphoreticular or vascular tumors. Thus, data from grossly detected liver tumors cannot be used with sufficient reliability to warrant the statistical effort.

As a final note, any reclassification to another type of tumor within the broad categories of either connective or epithelial tissue tumors is not as serious as a reclassification to the other category. For example, a lung tumor that is reclassified as a lymphoreticular tumor is of more concern than a vascular tumor reclassified as a lymphoreticular tumor. Dose-response and radiation quality factors are quite different for the two major categories.

\subsection{ANALYTICAL APPROACHES}

Although ORACLE is a powerful data management tool that permits the database to be easily transported to a variety of computer platforms and operating systems, its power also means that an elaborate and complex programming language exists between a researcher and the database. Consequently, an interactive menu-driven interface (MDI) on the computer system in the Center for Mechanistic Biology and Biotechnology was developed as an alternative to ORACLE for accessing the JANUS database. The MDI was designed specifically to be a flexible and easy-to-use tool for the researcher.

The philosophy governing the MDI has evolved through the years. Originally, the MDI provided options to perform such functions as regression analysis and the computation of various actuarial statistics. As new methods of analysis have constantly emerged, it was recognized that an analysis-oriented MDI would become progressively more complex and require constant vigilance over quality control in order to satisfy the demands of a changing set of researchers interested in the database. As a consequence, the generation of data files for subsequent analysis has become the primary function of the MDI today. One philosophical element of the MDI has remained invariant: the MDI provides access to the database, but it does not permit the database itself to be modified.

Age at death (failure time) is a fundamental unit of information in any study designed to investigate the biological effects resulting from exposure to radiation. Quantitative methods used to analyze failure times can be divided into either those that require individual death times or those that require the death times of individuals to be grouped into discrete time intervals. The MDI for the JANUS database provides the researcher with the option to select either of these two formats for data output. In the 
discrete case, the MDI also allows the specification of a fixed interval width format for the output file or an output file organized by user-defined intervals of varying widths.

The MDI database provides several additional capabilities for the analysis of failure times. For example, treatment codes (see Appendix J) can be provided during the dialog session to select the dose groups, exposure patterns, or radiation qualities that will be included in the output file. Gender-specific selections for individual dose groups in the output file can also be made.

Methods for failure-time analysis can also be subdivided into those used to analyze data on "cause of death" and those used to analyze data on incidence or prevalence. The MDI addresses the data requirements for these types of analyses by requiring the researcher during the dialog session to specify whether the data for the output file are for lethal events only (L), lethal plus contributory events (LC), or any observed pathology (LCN). It is also necessary to specify whether the data being output should be based on observations made at necropsy (gross pathology) or by histopathologic examination. As not all animals underwent histopathological examination, an option also exists to generate analysis files containing histopathology data for those mice where this information is available and gross pathology data for those mice lacking histopathology diagnoses.

When a specific cause of failure is the focus of an analysis (e.g., death resulting from a specific neoplasm), it is necessary to identify the subset of animals that died of the event of interest. When ungrouped data is being generated, those pathology endpoints considered events (lethal, or lethal plus contributory) for a mouse are set to unity and the pathology variables for non-events are set to zero. For grouped data, the selection of lethal or lethal plus contributory determines how the count of events for each pathology endpoint is computed.

In order to perform analyses, the codes used to describe specific pathologic events in the JANUS studies have been merged into three larger assemblages called combined pathology glossaries (Appendices K, L, and M). Each file generated by the MDI can contain up to 28 groups of these combined pathology codes. If the need arises, new databases can be created from combined pathology glossaries tailored to the specific research interests of the investigator. Once created, the new databases can be automatically accessed within an MDI session. The only restriction imposed on the researcher is that the analysis files generated through the MDI cannot contain more than 28 groups of pathology codes.

The MDI for the JANUS database is so easy to use that it can quickly lead to a proliferation of analysis files, which under typical work environments could lead to confusion over what information is actually contained in a given file. Fortunately, the MDI provides an automatic audit trail through the convention used to assign names to every file generated. Every file name begins with "LIFE" and ends with a five-digit number that provides a running count of the number of files that have been generated by the MDI. The data files are given the extension SIN (e.g., LIFE00932.SIN) and come paired with an IDX file (e.g., LIFE00932.(DX) that provides an index of the pathology versions and treatment group selections specified in the dialog session. In addition, a batch (extension BAT) file is created 
to actually generate the analysis files when a normal termination of the MDI session occurs. This batch file also contains an echo of the responses given in the MDI session. The MDI, therefore, allows an investigator to go back and determine exactly when a file was created, what it was called, and what information is contained within that file.

At present, direct access to the JANUS database is restricted to authorized personnel at ANL. However, access to analysis files generated from the database is available via collaborative arrangements with staff members in the Center for Mechanistic Biology and Biotechnology. Arrangements are currently being made to transfer an electronic version of the entire animal database to the National Radiobiology Archive, an organization at Pacific Northwest Laboratory charged with the Department of Energy (DOE) mandate to archive and provide public access to data generated from animal studies funded by DOE. 


\section{THE JANUS PROGRAM EXPERIMENTS}

\subsection{INTRODUCTION}

The JANUS program was first conceived in mid-1958 and subsequently went through a series of modifications and reevaluations. Generally, the plans tended to be grandiose, with the predictable criticism that the program would not be able to achieve programmatic goals either quickly or inexpensively. The program that ultimately emerged is probably best defined in Grahn et al. (1972) in a simple statement:

The primary program objectives are to obtain data for the development of realistic models of chronic radiation morbidity and mortality whereby long-term radiation injury can be understood and predicted in terms of: (1) cell injury and recovery; (2) tissue and organ injury, repair and regulation; and (3) the actuarial statistics of disease and death.

These goals were not beyond reach, but in many respects, they were not fully achieved generally because funding levels were not adequate, and the need for compromise prevailed. This archive contains the "actuarial statistics" and the associated pathology. There is no equivalent archive of the many studies done on hematology, immunology, cell injury and repair, and other areas, including dosimetry. Much of the work concerning nonactuarial data has been published, and a list of publications from the JANUS program is appended to this document (Appendix N).

\subsection{THE JANUS (JM) SERIES}

\subsubsection{JM-2}

JM-2 was the first, the largest, and the most ambitious of the JM series. One necessary objective was to test the additivity of small increments of neutron dose, when given in different patterns of exposure over a 24-wk period. With use of five different exposure patterns (Table 7 and Appendix J), a common total neutron dose of $240 \mathrm{cGy}$ was delivered. These ranged from a high-dose-rate single exposure to a fractionated exposure given in three low doses per week for $24 \mathrm{wk}$. A matching set of $\gamma$-ray exposures delivered a total dose of $855 \mathrm{cGy}$ in $24 \mathrm{wk}$ and a 788 -cGy single dose. These $\gamma$-ray and neutron exposures compared the influence of changes in dose rate, in the number of fractions, and in the protraction period on the long-term response. A three-dose/single-dose series was also included along with a matching set of sham-irradiated controls. This test of exposure patterns was important for future planning because the JANUS facility could not be used, for logistical and economic reasons, for 5-7 d of irradiation per week for $6-8 \mathrm{~h} / \mathrm{d}$ as had been done in our earlier studies with $\gamma$ rays (Grahn et al. 1994). 
The important objective was to evaluate the influence of these different exposure regimes on the endpoints of life shortening and neoplastic disease incidence and, in turn, on the estimation of RBE values. Sample sizes per sex, dose, and exposure pattern were sufficient to yield accurate estimates of the life table and pathology at death.

It was well known from previous studies that fractionation of a $\gamma$-ray dose would reduce its effectiveness, but the characteristics of specific exposure parameters were critical to the magnitude of this dose-rate effect. We were obliged to match every neutron pattern with $\gamma$-ray irradiations and were uncertain as to the additivity, or the magnitude of any deviations therefrom, of the neutron exposures. The choice of $24 \mathrm{wk}$ was a compromise that permitted an adequate protraction period (about $20 \%$ of the control mean after-survival [MAS]) yet also permitted a large and necessary experiment to be executed over a reasonable period. In fact, 10 full replications, involving a total of over 11,000 mice, were completed between March 1971 and June 1972.

A small age-dependence test was also included in JM-2. This involved two single doses of neutrons and of $\gamma$ rays given at about 200 and $300 \mathrm{~d}$ of age, spanning the 24-wk (168-d) fractionation period from 100 to $268 \mathrm{~d}$ of age. The single doses matched those given at $100 \mathrm{~d}$ of age.

No new studies were initiated until March 1974. This 2-yr hiatus permitted the Gammabeam 650 irradiator to be installed in the HLGF. The JM-2 data also accrued in this period to provide guidance for the next series of studies, JM-3, $-4 \mathrm{~K},-4 \mathrm{~W},-7$ and -8 , which were initiated in the spring and summer of 1974.

The results of JM-2 were presented in an interim status by Ainsworth et al. (1974, 1976) and in a more complete form by Thomson et al. (1981a). An important finding was the nonlinear response, in terms of life shortening, to the single neutron doses of 20,80 , and $240 \mathrm{cGy}$. The response was concave downward, with the effect at $20 \mathrm{cGy}$ being about 4 -fold greater per centigray than at $240 \mathrm{cGy}$. The 24 weekly fractionation procedure at $240 \mathrm{cGy}$ augmented the life-shortening response from about $1 \mathrm{~d}$ lost per centigray to about $1.5 \mathrm{~d}$. This type of dose- and fractionation-dependent response to neutrons, opposite to that seen for $\gamma$-ray irradiation, was an important consideration in program planning.

With regard to dose additivity for individual neutron exposures, there was no significant difference between the response to three exposures per week of $15 \mathrm{~min}$ each and one per week for $45 \mathrm{~min}$. Similarly, there was no difference in the response to one neutron exposure per week for $45 \mathrm{~min}$ and one per week for $360 \mathrm{~min}$. However, one exposure per 4-wk period for 180 min per exposure did cause a shift in response for both $\gamma$ rays and neutrons, but in opposite directions. The six larger once-monthly $\gamma$-ray increments were more effective than the smaller weekly exposures, while the opposite effect was noted for neutrons; the smaller weekly increments were more damaging. As a consequence of these results, all subsequent long-term neutron exposures employed the once-weekly, 45-min exposure paradigm, though there were some exceptions. Exposures to $\gamma$ rays matched the neutron exposures. 


\subsubsection{JM-3}

This was a straightforward single-dose study composed of seven replications that were run between April 1974 and June 1977. A small dose-rate comparison was also included in the last replication. It involved a single dose of $240 \mathrm{cGy}$ of neutrons given to males only. One group was exposed for the usual $20 \mathrm{~min}$, and a second group was exposed for $8 \mathrm{~h}$. Table 8 gives the full inventory and dose array for JM-3. Because of funding constraints, only about one-half of the originally intended number of females were included in the final inventory. Some were discarded after about $1 \mathrm{yr}$, and others were simply not entered in the study. However, as with JM-2, both MACRO and MICRO pathology records are quite complete in relation to the number entered.

The reason the entries into this study were stretched out over $3 \mathrm{yr}$ was due to competition for the available experimental animals. Concurrent with JM-3, five other studies were also being carried out, as will be noted.

\subsubsection{JM-4}

There are four experiments under the JM-4 rubric (we acknowledge this happenstance to be one of our few coding errors). The data are given in Tables 9 and 10, as well as in Appendix J. The basic study is known as JM-4K, as per the treatment codes for the total doses given in Table 9 , and it involved the 24 once-weekly exposure procedure that was employed in JM-2. Irradiations were carried out in 10 replications between August 1974 and April 1977. Some of the total doses were repeated in JM-3, JM-4L1, and JM-7 to provide a more direct test of dose-rate and protraction factors. The study was done concurrently with JM-3, JM-7, and JM-8.

Another concurrent study was JM-4W, which only employed females and two total dose levels each for $\gamma$ rays and neutrons (Table 9). The study, done in six replications between June 1974 and June 1978, was intended for a sacrifice-series study of vascular damage, which was carried out, but the original sample sizes were more than adequate (see Table 9) so that excellent survival data became available. No histopathology was performed; however, there are complete records for the gross findings.

The two studies listed as JM-4L (Table 10) were done in the early $1980 \mathrm{~s}, 3-5 \mathrm{yr}$ after the JM- $4 \mathrm{~K}$ study was executed. The first of these, JM- $4 \mathrm{~L} 1$, was originally intended to be carried out in parallel with JM-4K, as it involved four of the same total doses used in that study. The study involved $\gamma$-irradiated males only, and the protraction period was $23 \mathrm{wk}$, the same elapsed time for the 24 once-weekly procedure of JM- $4 \mathrm{~K}$. Dose rate was reduced by a factor of about 150 in the JM-4L1 study. Total doses were delivered over a 22 -h day, $5 \mathrm{~d} / \mathrm{wk}$ for the $23 \mathrm{wk}$ ( $6600 \mathrm{~min}$ of exposure per week vs. one 45-min exposure per week). No comparable neutron exposures were possible. Irradiations were done in four replications between November 1980 and June 1981. 
The second low-dose-rate study, JM-4L2, was planned to parallel the JM-13 study, which involved a 60-exposure, once-weekly regime. The JM-4L2 experiment employed the same exposure procedure as JM-4L1, but it extended the protraction period to $59 \mathrm{wk}$, the elapsed time for the 60 once-weekly exposures. Again, only males were used, and no neutron exposures could be done to match the $\gamma$-ray irradiations. Five replications were exposed between July 1983 and October 1984.

The exposure, caging, and animal handling procedures had to be different for these two low-dose-rate studies. These were described in Section 2.2. The irradiations were performed in the low-level $\gamma$-ray facility previously described in Grahn et al. (1994). A portable Gammabeam 150 irradiator with a single ${ }^{60}$ Co source was used for the irradiations. Dose rate was controlled by distance from the irradiator, which was located in an off-center position in the room. A constant exposure day of $22 \mathrm{~h}, 5 \mathrm{~d} / \mathrm{wk}$, was used throughout the two studies. Both studies used the same three lowest weekly total doses, 8.96, 18.13, and $41.7 \mathrm{cGy} / \mathrm{wk}$, but source decay prevented our being able to accommodate a fourth dose in JM-4L2 at 4-5 cGy/wk and still include the highest level.

The source-handling mechanism described in Grahn et al. (1994) had been decommissioned in the late 1970s and was replaced with the "portable" Gammabeam 150 unit, originally fitted with a $6-$ to $8-\mathrm{Ci}{ }^{60} \mathrm{Co}$ source. This unit was used for both JM-4L experiments. There were no unusual dosimetric aspects, so the same kerma-tomidline-tissue-dose parameters were used as in the HLGF.

\subsubsection{JM-7}

JM-7 (Table 11) used a 60-exposure, once-weekly procedure (treatment code Q) to extend the protraction period to approximately 50\% of the normal life expectancy from $100 \mathrm{~d}$ of age, when the weekly exposures were initiated. This experiment used only two total doses each for $\gamma$ rays and neutrons, and these matched two that were used in JM-4K. One $\gamma$-ray dose and both neutron doses were also a repeat of JM-3, and both $\gamma$-ray doses were repeated in JM-4L1. To evaluate the age-at-exposure variable, JM-7 also included a single-dose component (treatment code $\mathrm{R}$ ) at approximately $520 \mathrm{~d}$ of age, the end of the 60 once-weekly series. Two doses each for $\gamma$ rays and neutrons were used, and these matched doses used in JM-3 and JM-4.

The 60-week series involved 10 replications over the period from March 1974 to July 1978. The six replications of the single-dose test were irradiated between April 1975 and April 1977. These replications were from an unexposed portion of the first six replications of the 60-week series. They were then irradiated on the same date as the last of the 60 weekly exposures. 


\subsubsection{JM-8}

This was the only duration-of-life exposure experiment done in the JM series. It was ostensibly intended to link the JANUS program to the extensive duration-of-life studies done in pre-JANUS experiments (see Grahn et al. 1994) and to compare protraction factors between the 24 and the 60 once-weekly paradigms with the duration-of-life procedure.

The exposures were given once weekly, as in the 24- and 60-wk studies, and three weekly dose levels were used for both $\gamma$ rays and neutrons. The weekly dose levels are found in Table 12. Mean total doses would be the product of these weekly doses and the mean number of weeks of survival. The lowest and highest weekly doses of the three, for both $\gamma$ rays and neutrons, were the same weekly doses used for the JM-7 60 once-weekly series, which tied these two experiments together. The middle dose levels, 17.4 and $1.67 \mathrm{cGy} / \mathrm{wk}$ for $\gamma$ rays and neutrons, respectively, were the same rates used in JM-4K to reach total doses of 417 and $40 \mathrm{cGy}$ in $24 \mathrm{wk}$ of exposure. Between 1 and 10 replications were used, and these were initiated between April 1974 and May 1980. Sample sizes for the females were not adequate for most dose groups but were sufficient for males.

\subsubsection{JM-9}

Owing to administrative and budgetary changes in mid-1977, experimental priorities changed. One change was the more pressing need for truly low-dose studies, especially with neutrons, because of accumulating evidence that higher levels of damage per centigray were induced at doses below 20-40 cGy as compared with that at doses above that level. The JM-9 experiment developed from this background. It consisted of two phases (Table 13). The first was a preliminary study carried out between June 1977 and March 1978 and was composed of only five replications. Only two neutron dose levels were used, 5 and 10 cGy. The latter was delivered in both the single dose and the 24 once-weekly regimes.

The second phase was performed with 10 replications between February and August 1980. Though restricted to the female, it was a large study that used larger sample sizes at the lowest doses than had been used in any previous studies. An excellent gross pathology file was created, and about $40 \%$ of the mice had a histopathology follow-up. This study also provided the first good example of an essentially null response dose, the 1-cGy neutron dose.

\subsubsection{JM-10}

From the outset, the JANUS program intended to include studies that compared the responses of several species, though the primary species was always to be Mus musculus, the mouse. Plans included studies with beagles, guinea pigs, and several species of wild mammals that had been captured and established in breeding colonies in the ANL animal facilities. The original intention was to provide a multiple-species database for comparisons that would enable an improved interspecies modeling effort, with the ultimate goal of predicting human responses to neutron and $\gamma$-ray exposures. The usual funding, manpower, 
and programmatic deficiencies limited this interspecies comparison effort to one laboratorymaintained, long-lived field mouse, Peromyscus leucopus (see also Section 2.1.1.2).

The exposures of $P$. leucopus were done between November 1977 and March 1979 in 10 replications. Only males were employed. The dose levels were repeats of those used in JM-3 and JM-4K. Single exposures to both $\gamma$ rays and neutrons were employed, and two total dose levels of neutrons were given in the 24 once-weekly procedure (Table 14, treatment codes VV and VW).

As shown in Table 14, the control MAS for P. leucopus is about 50\% longer than that of the $\mathrm{B}_{6} \mathrm{CF}_{1}$ mouse, though body size was not that much greater. In general, the response in terms of life shortening was not particularly different from that of the $\mathrm{B} \mathrm{CF}_{1}$ mouse, but a different spectrum of pathology was seen at death. No histopathology is available, however.

\subsubsection{JM-12}

A curious aspect of the response to neutrons concerns the so-called reverse dose-rate effect; that is, as neutron doses are protracted or fractionated, life shortening (among other responses) is augmented. This was seen in JM-2 and in the comparison of JM-3 with JM-4K. A small study, JM-12 (Table 15), was carried out to test the relationship of this augmentation phenomenon to the short-term fractionation of dose specifically, by delivering a given total dose in only 1,2, 4, or 6 fractions at 1-wk intervals. Only males were used, and the irradiations were carried out in six replications between November 1979 and April 1980. Though no histopathology was done, the gross pathology record is complete.

\subsubsection{JM-13}

The last major study of the life-shortening and pathologic responses was the JM-13 experiment (Table 16). In contrast to all previous studies, JM-13 was not funded by the U.S. Department of Energy (DOE). It was fully funded by the U.S. Nuclear Regulatory Commission (NRC), which was concerned about the potential risks associated with the periodic exposure of utility workers in the nuclear power industry to fission neutrons, especially at pressurized-water reactor facilities. The lowest total neutron dose of $2 \mathrm{cGy}$, delivered in 60 once-weekly exposures of $20 \mathrm{~min}$ each, required a dose rate of only $0.00167 \mathrm{cGy} / \mathrm{min}$. This was achieved with a high degree of reliability.

Another unique feature of the JM-13 study was the inclusion, from concept to completion, of a series of periodic genetic evaluations of males drawn randomly from the control and irradiated groups during the course of the exposures. The paradigm of $60 \mathrm{wk}$ of exposure was chosen as it was a reasonable approximation of a working lifetime for persons in the industry. Sixty weeks is also about $50 \%$ of the MAS for a young adult mouse. This would be roughly equivalent to a $30-$ to $40-\mathrm{yr}$ period starting at 20 to $25 \mathrm{yr}$ of age for a human population in the United States. 
A concurrent issue at the time JM-13 was being executed (February 1981 to August 1982 for the exposure sequence) was the "quality factor" (Q) or, experimentally, the RBE for neutrons at very low doses delivered at low dose rates. The accepted value of 10 for fission neutrons was believed by many to be an underestimate. We expected JM-13 to make a significant contribution toward the resolution of this concern about the neutron $R B E$, because the study was addressing both somatic and genetic responses to low total neutron doses ( $<10 \mathrm{cGy}$ ) delivered at extremely low rates.

Table 16 indicates that, on average, only about $50 \%$ of the autopsied animals were subject to a histopathological examination. This level of pathology study was set by agreement with the NRC, the funding agency.

\subsubsection{JM-14}

JM-14 (Table 17) was the last major study of the JANUS program, now under the leadership of D.J. Grdina. Funding for this experiment was divided among the DOE, the National Cancer Institute of the National Institutes of Health, and the Center for Radiation Therapy of the University of Chicago. The primary purpose was to evaluate the efficacy of several radioprotector agents against the induction of late effects, specifically life shortening and tumorigenesis. The agents were WR-2721 [S-2-(aminopropyl-amino)ethylphosphorothioic acid] and WR-151327 [S-3(3-methylaminopropylamino)propyl-phosphorothioic acid].

The study used single doses of $\gamma$ rays and neutrons at levels previously employed in the program (JM-3, JM-9). Animals were injected intraperitoneally $30 \mathrm{~min}$ before irradiation with either the radioprotector or saline. The irradiations were carried out between October 1984 and October 1985. At this time, the histopathology record is incomplete; however, a complete gross pathology record is in the file. 


\section{SUMMARY}

\subsection{INTRODUCTION}

A complete review of all results of the long-term effects of whole-body $\gamma$-ray and neutron irradiations performed in the JANUS program cannot be given here. Instead, this brief summary will identify the major findings and, also, some of the unresolved issues as we currently see them. The results are presented in more complete form in published articles (see Appendix N), but there is no single summarizing published report. At the writing of this report (late 1994), there are still portions of the data that have not been fully analyzed and, in some cases, that have not been analyzed at all. A quick introduction for the reader to the life-shortening data of the individual $J M$ experiments can be found in the following references:

JM-2

JM-3

$\mathrm{JM}-4 \mathrm{~K},-4 \mathrm{~W}$

JM-4L1, -4L2

JM-7

JM-8

JM-9

JM-10

JM-12

JM-13

JM-14
Ainsworth et al. (1976); Thomson et al. (1981a)

Thomson et al. (1981a)

Thomson et al. (1981a)

Thomson and Grahn (1989)

Thomson et al. (1981b)

Thomson et al. (1981b)

Thomson et al. (1983, 1985b)

Thomson et al. (1986)

Thomson et al. (1985a)

Thomson and Grahn (1988)

Grdina et al. (1991a,b); Carnes and Grdina (1992)

Comprehensive analyses and modeling of life-shortening effects are in Carnes et al. (1989) and Carnes and Grahn (1991). A summary and analysis of major tumorigenic responses are in Grahn et al. (1992). A combined, but incomplete, summary of genetic, life-shortening, and tumorigenic responses was published earlier in Grahn et al. (1986).

\subsection{THE NEUTRON/GAMMA-RAY RBE}

Obviously, there is no single best estimate of the RBE. The major variables that influence the RBE value are discussed in the following sections.

\subsubsection{Sex}

There is no specific sex-related factor influencing the RBE that cannot be related to sex-specific tumor incidence or death. While there are sex differences in neoplastic disease incidence, there is no significant sex difference in overall life shortening per unit dose. 


\subsubsection{Total Dose/Dose Rate/Protraction Period/Fractionation Pattern}

One always wishes that the dose variables could be stratified to bring out the specific contributions of each variable. Unfortunately, they are a matrix of interdependent variables, and the JM series certainly did not exhaust the options. In terms of life-shortening estimates per cumulative dose (centigray), the RBE for single, low neutron doses would be about 10 $(-4 \mathrm{~d} / \mathrm{cGy}$ of neutrons vs. $-0.4 \mathrm{~d} / \mathrm{cGy}$ of $\gamma$ rays), but this $\mathrm{RBE}$ would drop to 5 or less as the neutron dose goes above $40 \mathrm{cGy}$. Assuming complete additivity of small increments of neutron doses accumulating to $10 \mathrm{cGy}$ or less, the RBE would range between 25 and 40 against comparable $\gamma$-ray exposures. Neutron effectiveness is lower per centigray at doses above $40 \mathrm{cGy}$ than at doses of $20 \mathrm{cGy}$ or less, regardless of exposure parameters.

For $\gamma$ rays, decreasing the dose rate, increasing the protraction period, and reducing the size of a dose fraction all act to diminish life-shortening effects. The "round numbers" for this series of experiments, the number of days lost per centigray of $\gamma$ rays, are as follows:

$\begin{array}{llll}\text { single dose } & 0.40 & 23 \mathrm{wk}, 5 \times 22 \text {-h days } & 0.16 \\ 24 \text { weekly doses } & 0.20 & 59 \text { wk, } 5 \times 22 \text {-h days } & 0.08 \\ 60 \text { weekly doses } & 0.14 & \text { duration-of-life, weekly dose } & 0.09\end{array}$

The life-shortening effect of daily duration-of-life exposure to $\gamma$ rays for $8 \mathrm{~h} / \mathrm{d}$ is $0.04 \mathrm{~d}$ per cumulative centigray at doses less than $20 \mathrm{cGy} / \mathrm{d}$, as was seen repeatedly in the pre-JANUS studies at ANL (Grahn et al. 1994). Thus, while the maximum $n / \gamma$ RBE in the JM series is about $50(4.0 / 0.08)$, it would be $100(4.0 / 0.04)$ if the pre-JANUS studies at ANL were used as the low-LET baseline.

\subsubsection{Dose-Response Functions}

There were no unusual dose-response functions for any of the long-term somatic or genetic endpoints. The response to $\gamma$ rays was predominantly linear, regardless of the exposure variables involved. Not only were they usually linear, but they uniformly extrapolated close to the 0,0 intercept. The occasional response was linear-quadratic, a second degree polynomial with a positive dose-squared term.

For neutron exposures, the responses were mixed. Depending on the range of total doses involved, they were either linear or linear-quadratic, with a negative second-degree term.

A variety of dose-response models were evaluated, but the simplest models prevailed (Carnes et al. 1989). RBE values were therefore easily derived from the ratio of linear terms, $\beta n / \beta \gamma$. 


\subsubsection{Age at Exposure}

This variable was only tested with single doses at three ages greater than the standard age of $100 \pm 15 \mathrm{~d}$. The three ages were approximately 200,300 , and $500 \mathrm{~d}$ of age. The RBE value at the older ages was not substantially different from that at $100 \mathrm{~d}$ of age at exposure when measured in terms of the life-shortening response. Life shortening itself was dependent on age at exposure. In terms of days lost per centigray, the values for $\gamma$ rays were $0.5,0.3,0.2,0.2$, for $100,200,300$, and $500 \mathrm{~d}$ of age at exposure, respectively; for neutrons, the values were $1.0,0.6,0.3$, and 0.5 . These rather low values for neutron exposures were due to the unfortunate choice of dose levels ( $40 \mathrm{cGy}$ up to $240 \mathrm{cGy}$ ), where the life-shortening effect steadily diminishes with increasing dose.

Though these data did not have a specifically identified control group from which the after-expectations of life could be derived for each age-at-exposure group, reasonable approximations can be made from other controls. The diminishing life-shortening term is probably reasonably accurate; however, the data also reveal that this phenomenon is likely to be a reflection of a reduction in age-specific tumor-related death rates at fixed age intervals as age at exposure increases. Latency may not be shortened as age at exposure increases, and tumor yields may be similar at comparable elapsed time periods after irradiation. These elapsed time periods, when converted to ages, reveal that tumors occur progressively later in life and thus have less influence on life shortening. These data need further analysis.

\subsubsection{Endpoint}

Obviously, RBE values are dependent on the endpoint. In general terms, the $\mathrm{RBE}$ values for life shortening are the best estimates for overall somatic effects, because life shortening at low doses principally reflects excess mortality attributable to neoplastic disease. The maximum RBE values occur at low doses, where about $85 \%$ or more of the life shortening can be attributed to excess tumor-related mortality. Within the broad class of neoplastic disease, however, considerable heterogeneity exists in the induction rates for different types of tumors for the two radiation qualities.

Epithelial tissue tumors are induced by neutrons at higher rates per centigray than are connective tissue tumors. The lowest RBE value, $2 \pm 0.3$, is thus seen for lymphoreticular tumors induced by single doses, and the highest significant values are between 50 and 100 for tumors of the liver, Harderian gland, and other glandular and reproductive system tumors, except for those of the ovary. The RBE range for life shortening is between 5 and 45 , depending on the dose-rate factors that parallel the same range for tumorigenesis. This range of RBE values and its relationship to dose-rate and fractionation factors is also seen in the cumulative induction of reciprocal chromosome aberrations in the stem cells of the male germ line. 


\subsection{UNRESOLVED ISSUES}

No series of experiments in radiation biology has ever succeeded in solving all the problems it set out to resolve, and, usually, a new set of problems is created. The JANUS program was no different from other experiences.

\subsubsection{Dose-Response Functions}

There remains a need for more data on the responses to $\gamma$ radiation at doses between 5 and 50 cGy for both sexes. Similarly, the data from neutron exposures at 2-20 cGy need to be reinforced equally for both sexes. While we believe the response to $\gamma$ rays is linear at low doses and will continue to extrapolate to the 0,0 intercept, this assumption needs more support. For neutron irradiations, the essentially linear response, through the intercept, at doses between 1 and 20 cGy needs to be confirmed for both sexes with a broader variety of dose-rate and fractionation factors.

\subsubsection{Dose Rate, Fractionation and Protraction Factors}

The JM series left some gaps in this area. Dose-response data for both sexes were not balanced, and the short-term 24 once-weekly sequence was particularly not satisfactory. The one duration-of-life series left unanswered the matter of bridging the databases from the pre-JANUS studies with those of the JANUS studies. The once-weekly duration-of-life procedure was twice as effective for life shortening than the daily, $8 \mathrm{~h} / \mathrm{d}$, duration-of-life procedure for $\gamma$ radiation. The neutron duration-of-life series, unfortunately, did not go to a low enough total dose, so the response to lifetime accumulations of less than 20 40 cGy remains unanswered, though we would predict it would converge on the responses to the short-term exposure parameters that were employed.

\subsubsection{Age at and during Exposure}

This issue encompasses problems of long standing in radiobiology: Why do responses seem to lessen with increasing age, and why does the concept of "wasted radiation" still find adherents? The JM series noted that responses to $\gamma$ rays declined from 1 to 24 to 60 wk of exposure and that a lower instantaneous dose rate within the 24 and 60 procedures also had a reduced effectiveness. There was a significant difference between 60 once-weekly and duration-of-life once-weekly, but no difference appeared between the latter and exposures for 59 weeks, $22 \mathrm{~h} / \mathrm{d}$ for $5 \mathrm{~d} / \mathrm{wk}$. Nevertheless, both procedures were still twice as effective as daily duration-of-life exposures for $8 \mathrm{~h} / \mathrm{d}$. Obviously, radiation cannot be "wasted" in the sense that it truly lacks any effectiveness. Depending on the endpoint, effectiveness diminishes under certain long-term exposure conditions, and this remains to be rationalized. 


\subsubsection{Neoplastic Diseases}

Several issues that relate to tumor incidence and mortality have yet to be addressed in this database. One concerns the question of tumor multiplicity, that is, are there important radiation quality, dose, sex, and age factors that may be manifest in the occurrence of two or more neoplastic conditions in the same animal? Another issue concerns the degree of malignancy of induced tumors and its relation to the noted variables. This could be addressed by a careful survey of metastatic tumors. A third concern relates to the variability in tumor induction that may be conditioned by genetic background. As the JM series used only one $F_{1}$ hybrid mouse, which was characterized by a high spontaneous frequency of both lymphoreticular and lung tumors, there is somewhat limited information on the full spectrum of tumors that might be seen and on their rates of induction, dose-response parameters, and RBE values.

\subsubsection{Other Issues}

The circumstance wherein groups exposed to low doses, low dose rates, or both have an MAS greater than their specific controls (the "hormesis" issue) was not a problem in these studies. There were three cases of "over-survival," all nonsignificant. These were, in terms of life shortening, JM-3: 0 vs. 90 cGy of $\gamma$ rays, females, $-5 \pm 20 \mathrm{~d}$; JM-9: 0 vs. 1 cGy of neutrons, females, $-2 \pm 10 \mathrm{~d}$; and JM-13: 0 vs. 2 cGy of neutrons, males, $-9 \pm 11 \mathrm{~d}$.

The 90- and 2-cGy groups both showed a deficit in the cumulative risk of lymphoreticular tumors, a dominant cause of death in the $\mathrm{BCF}_{1}$ mouse. Both groups also showed an excess risk for epithelial tissue tumors, many of which are classed as contributory or nonlethal. The 1-cGy neutron group of females was an almost exact replication of its control for all causes and all dominant pathology. In other words, this instance is the closest to a threshold exposure in our experience. Even the ovarian tumor incidence was unchanged from the control, but there were small excess risks at 1 cGy for lymphoreticular, kidney, gastrointestinal, adrenal, and Harderian gland tumor occurrences. Thus, while life shortening may seem to show an hormetic effect, many specific tumor occurrences will demonstrate radiation injury, as will the germinal tissues. 


\section{REFERENCES}

Ainsworth, E.J., R.J.M. Fry, P.C. Brennan, S.P. Stearner, J.H. Rust, and F.S. Williamson, 1976, Life shortening, neoplasia, and systemic injuries in mice after single or fractionated doses of neutron or gamma radiation, in Biological and Environmental Effects of Low-Level Radiation, vol. I, International Atomic Energy Agency, Vienna, pp. 77-92.

Ainsworth, E.J., R.J.M. Fry, D. Grahn, F.S. Williamson, P.C. Brennan, S.P. Stearner, A.V. Carrano, and J.H. Rust, 1974, Late effects of neutron or gamma radiation in mice, in Biological Effects of Neutron Irradiation, International Atomic Energy Agency, Vienna, pp. 359-379.

Bennett, E.F., and T.J. Yule, 1972, A neutron spectrum map of the JANUS irradiation facility using proton-recoil proportional counters, Radiation Research 50:219-233.

Borak, T.B., and T.G. Stinchcomb, 1979, Calculations of charge-particle recoils, slowing-down spectra, LET and event-size distributions for fast neutrons, and comparisons with measurements, Physics in Medicine and Biology 24:18-36.

Carnes, B.A., and D. Grahn, 1991, Issues about neutron effects: the JANUS program, Radiation Research 128:S141-S146.

Carnes, B.A., D. Grahn, and J.F. Thomson, 1989, Dose-response modeling of life shortening in a retrospective analysis of the combined data from the JANUS program at Argonne National Laboratory, Radiation Research 119:39-56.

Carnes, B.A., and D.J. Grdina, 1992, In vivo protection by the aminothiol WR-2721 against neutron-induced carcinogenesis, International Journal of Radiation Biology 61:567-576.

Grahn, D., E.J. Ainsworth, F.S. Williamson, and R.J.M. Fry, 1972, A program to study fission neutron-induced chronic injury in cells, tissues, and animal populations, utilizing the JANUS reactor of the Argonne National Laboratory, in Radiobiological Applications of Neutron Irradiation, International Atomic Energy Agency, Vienna, pp. 211-228.

Grahn, D., C. Fox, B.J. Wright, and B.A. Carnes, 1994, Studies of Acute and Chronic Radiation Injury at the Biological and Medical Research Division, Argonne National Laboratory, 1953-1970: Description of Individual Studies, Data Files, Codes, and Summaries of Significant Findings, Argonne National Laboratory report ANL-94/26, $99 \mathrm{pp}$.

Grahn, D., L.S. Lombard, and B.A. Carnes, 1992, The comparative tumorigenic effects of fission neutrons and cobalt- $60 \gamma$ rays in the $\mathrm{B}^{-\mathrm{CF}_{1}}$ mouse, Radiation Research 129:19-36. 
Grahn, D., J.F. Thomson, B.A. Carnes, F.S. Williamson, and L.S. Lombard, 1986, Comparative biological effects of low dose, low dose-rate exposures to fission neutrons from the JANUS reactor or to Co-60 gamma rays, Nuclear Science Applications 2:385-396.

Grdina, D.J., B.A. Carnes, D. Grahn, and C.P. Sigdestad, 1991a, Protection against late effects of radiation by $S$-2-(3-aminopropylamino)-ethylphosphorothioic acid, Cancer Research 51:4125-4130.

Grdina, D.J., B.J. Wright, and B.A. Carnes, 1991b, Protection by WR-151327 against lateeffect damage from fission-spectrum neutrons, Radiation Research 128:S124-S127.

ICRU, 1979, Quantitative Concepts and Dosimetry in Radiobiology, Report 30, International Commission on Radiation Units and Measurements, Bethesda, Maryland, pp. 44-47.

Marshall, I.R., and F.S. Williamson, 1985, Microdosimetric spectra measurements of JANUS neutrons, Radiation Protection Dosimetry 13:111-115.

Neary, G.J., R.J. Munson, and R.H. Mole, 1957, Chronic Radiation Hazards, Pergamon Press, New York, pp. 190.

Neary, G.J., and F.S. Williamson, 1961, A simple method of fast-neutron dosimetry for use in radiobiology and an intercomparison with some methods used in the United States, in Selected Topics in Radiation Dosimetry, International Atomic Energy Agency, Vienna, pp. 463-471.

Sacher, G.A., and R.W. Hart, 1978, Longevity, aging, and comparative cellular and molecular biology of the house mouse, Mus musculus, and the white-footed mouse, Peromyscus leucopus, Birth Defects 14:76-96.

Thomson, J.F., and D. Grahn, 1988, Life shortening in mice exposed to fission neutrons and $\gamma$ rays. VII. Effects of 60 once-weekly exposures, Radiation Research 115:347-360.

Thomson, J.F., and D. Grahn, 1989, Life shortening in mice exposed to fission neutrons and $\gamma$ rays. VIII. Exposures to continuous $\gamma$ radiation, Radiation Research 118:151-160.

Thomson, J.F., F.S. Williamson, and D. Grahn, 1983, Life shortening in mice exposed to fission neutrons and $\gamma$ rays. III. Neutron exposures of 5 and $10 \mathrm{rad}$, Radiation Research 93:205-209.

Thomson, J.F., F.S. Williamson, and D. Grahn, 1985a, Life shortening in mice exposed to fission neutrons and $\gamma$ rays. IV. Further studies with fractionated neutron exposures, Radiation Research 103:77-88.

Thomson, J.F., F.S. Williamson, and D. Grahn, 1985b, Life shortening in mice exposed to fission neutrons and $\gamma$ rays. $V$. Further studies with low single doses, Radiation Research 104:420-428. 
Thomson, J.F., F.S. Williamson, and D. Grahn, 1986, Life shortening in mice exposed to fission neutrons and $\gamma$ rays. VI. Studies with the white-footed mouse, Peromyscus leucopus, Radiation Research 108:176-188.

Thomson, J.F., F.S. Williamson, D. Grahn, and E.J. Ainsworth, 1981a, Life shortening in mice exposed to fission neutrons and $\gamma$ rays. I. Single and short-term fractionated exposures, Radiation Research 86:559-572.

Thomson, J.F., F.S. Williamson, D. Grahn, and E.J. Ainsworth, 1981b, Life shortening in mice exposed to fission neutrons and $\gamma$ rays. II. Duration-of-life and long-term fractionated exposures, Radiation Research 86:573-579.

Vogel, H.H. Jr., R.A. Blomgren, and N.J.G. Bohlin, 1953, Gamma-neutron radiation chamber for radiobiological studies, Nucleonics 11:28-31.

Williamson, F.S., and N.A. Frigerio, 1972, Field mapping and depth dosimetry in the JANUS high flux irradiation room-a fast neutron facility for biological research, in Proceedings of the First Symposium on Neutron Dosimetry in Biology and Medicine, vol. II, Commission of the European Communities, Luxembourg, pp. 743-755.

Williamson, F.S., N.A. Frigerio, G.L. Holmblad, J.E. Trier, and E.G. Johnson Jr., 1971, Neutron and gamma dosimetry for the JANUS program, in Biological and Medical Research Division Annual Report, Argonne National Laboratory report ANL-7870, pp. 5-8.

Williamson, F.S., N.A. Frigerio, G.L. Holmblad, J.E. Trier, and E.G. Johnson Jr., 1972, Neutron dosimetry for the JANUS program, in Biological and Medical Research Division Annual Report, Argonne National Laboratory report ANL-7970, pp. 9-11.

Williamson, F.S., G.L. Holmblad, J.E. Trier, and E.G. Johnson Jr., 1973, Dosimetry of cobalt-60 gamma radiation in the JM-2 experiment, in Biological and Medical Research Division Annual Report, Argonne National Laboratory report ANL-8070, pp. 26-27. 
TABLE 1 Composition of Combined Pathology Database $<\mathrm{E}>$

Group Included Pathology

$1 \quad$ Cause of death undetermined

Tumor pathology

$2 \quad$ Lymphoreticular tumors

3 Vascular tumors

4 Connective tissue tumors other than lymphoreticular and vascular

$5^{\mathrm{a}} \quad$ Respiratory system

$6^{\mathrm{a}} \quad$ Harderian gland

$7^{\mathrm{a}} \quad$ Liver and gallbladder

$8^{\mathrm{a}} \quad$ Kidneys and urinary bladder

$9^{\mathrm{a}} \quad$ Gastrointestinal tract

$10^{\mathrm{a}} \quad$ Adrenal gland

$11^{\text {a }} \quad$ Pituitary gland

$12^{\mathrm{a}} \quad$ Thyroid gland

$13^{\mathrm{a}} \quad$ Testes and seminal vesicles

$14^{\mathrm{a}} \quad$ Mammary glands

$15^{\mathrm{a}} \quad$ Uterus

$16^{\mathrm{a}} \quad$ Ovaries

$17^{\mathrm{a}}$ Skin and other epithelial tissue tumors not included in groups 5 through 16

18 Any secondary connective tissue tumor at any site

19 Secondary tumors of Harderian gland origin, any site

20 Secondary tumors of respiratory system origin, any site

21 All other secondary tumors, any site

Nontumor pathology

22 Acute or chronic disease of the liver

23 Acute or chronic pulmonary disease

24 Acute or chronic cardiovascular disease

25 Acute or chronic renal disease

26 Ovarian cyst

27 Amyloid infiltration

28 All other nonneoplastic diseases, acute or chronic

a Groups 5 through 17 involve neoplastic diseases of epithelial tissue origin, with the exception of certain tumors of mixed origin involving the adrenal and mammary glands. 
TABLE 2 Composition of Combined Pathology Database <F>

\begin{tabular}{cl}
\hline Group & \multicolumn{1}{c}{ Included Pathology } \\
\hline 1 & Any primary tumor of connective and/or epithelial tissue origin, \\
& $\quad$ including ovarian tumors \\
2 & Any primary connective tissue tumor \\
3 & Any primary epithelial tissue tumor, excluding ovarian tumors \\
4 & Lymphoreticular tumors (group 2, database $<$ E $>$ ) \\
$5^{\mathrm{a}}$ & Histiocytic lymphoma, type A reticulum cell tumor \\
$6^{\mathrm{a}}$ & Lymphocytic-lymphoblastic leukemia \\
$7^{\mathrm{a}}$ & Lymphocytic-lymphoblastic lymphoma \\
$8^{\mathrm{a}}$ & Unclassified lymphoma \\
$9^{\mathrm{a}}$ & Mixed histiocytic-lymphocytic lymphoma, type B reticulum cell tumor \\
$10^{\mathrm{a}}$ & All other lymphoreticular tumors \\
$11^{\mathrm{b}}$ & Hemangioma, any site \\
$12^{\mathrm{b}}$ & Angiosarcoma, any site \\
13 & All vascular tumors (group 3, database $<\mathrm{E}>$ ) \\
14 & Fibroma, fibrosarcoma, undifferentiated sarcoma, any site \\
15 & All other connective tissue tumors not included in groups 5 through 14 \\
16 & Connective tissue tumors other than lymphoreticular and vascular \\
& (group 4, database <E $>$ ) \\
17 & Liver, hepatocellular tumors \\
18 & Liver, bile duct tumors \\
19 & Adrenal cortical tumors \\
20 & Adrenal medullary tumors \\
21 & Ovary, all tumors (group 16, database $<\mathrm{E}>$ ) \\
$22^{\mathrm{c}}$ & Ovary, granulosa cell tumor \\
$23^{\mathrm{c}}$ & Ovary, tubular adenoma \\
$24^{\mathrm{c}}$ & Ovary, luteoma (thecoma) \\
$25^{\mathrm{c}}$ & All other ovarian tumors \\
26 & Tumors of the kidneys, liver, gastrointestinal system, and skin \\
27 & Tumors of the mammary glands, adrenal glands, pituitary gland, \\
28 & thyroid gland, uterus, testes, and seminal vesicles \\
\hline & As in group 27 plus the Harderian gland \\
\hline
\end{tabular}

a Specific cellular subclasses of the lymphoreticular tumors.

b Subclasses of vascular tumors.

c Sublasses of ovarian tumors. 
TABLE 3 Composition of Combined Pathology Database $<\mathbf{H}>$

\begin{tabular}{cl}
\hline Group & \multicolumn{1}{c}{ Included Pathology } \\
\hline 1 & Any primary tumor of connective and/or epithelial tissue \\
& $\quad$ origin, including ovarian tumors (group 1, database $<\mathrm{F}>$ ) \\
2 & Any primary connective tissue tumor (group 2, database $<\mathrm{F}>$ ) \\
3 & Any primary epithelial tissue tumor excluding ovarian tumors \\
4 & $\quad$ (group 3, database $<\mathrm{F}>$ ) \\
5 & Lymphoreticular tumors (group 2, database $<\mathrm{E}>$ ) \\
6 & Reticulum cell sarcoma \\
7 & Lymphocytic leukemia \\
8 & All carcinomas \\
9 & All sarcomas \\
10 & All fibromas \\
11 & All fibrosarcomas \\
12 & Alveologenic tumor (adenoma), benign \\
13 & Alveologenic tumor (adenocarcinoma), malignant \\
14 & All adrenal tumors (group 10, database $<\mathrm{E}>$ ) \\
15 & Adrenal cortical tumors (group 19, database $<\mathrm{F}>$ ) \\
16 & Adrenal medullary tumors (group 20, database $<\mathrm{F}>$ ) \\
17 & Hepatocellular tumors (group 17, database $<\mathrm{F}>$ ) \\
18 & Kidney tumors \\
19 & All mammary gland tumors (group 14, database $<\mathrm{E}>$ ) \\
20 & All gastrointestinal tract tumors (group 9, database $<\mathrm{E}>$ ) \\
21 & All bone tumors \\
22 & Metastasis from lung tumor to any site (group 20, \\
23 & database $<\mathrm{E}>$ ) \\
24 & Metastasis from kidney to any site \\
25 & Metastasis from Harderian gland tumor to any site (group 19, \\
26 & Matabase $<\mathrm{E}>$ ) \\
27 & Metastasis from bone tumor to any site \\
28 & Metastasis from any site to lung \\
& All metastatic tumors (secondaries) \\
\hline &
\end{tabular}


TABLE 4 JANUS Program Records Summary

\begin{tabular}{lrrrr}
\hline $\begin{array}{c}\text { Experiment No. } \\
\text { (JM-) }\end{array}$ & Input & $\begin{array}{c}\text { Death } \\
\text { Records }\end{array}$ & $\begin{array}{c}\text { Gross } \\
\text { Pathology }\end{array}$ & Histopathology \\
\hline & & & & \\
2 & 11,590 & 9,947 & 9,205 & 7,838 \\
3 & 3,280 & 2,867 & 2,732 & 2,204 \\
$4 \mathrm{~K}$ & 6,070 & 4,739 & 4,465 & 3,193 \\
$4 \mathrm{~W}$ & 2,200 & 1,519 & 1,462 & 0 \\
$4 \mathrm{~L} 1$ & 620 & 598 & 567 & 364 \\
$4 \mathrm{~L} 2$ & 525 & 516 & 508 & 371 \\
7 & 2,735 & 2,676 & 2,554 & 438 \\
8 & 1,880 & 1,292 & 1,197 & 239 \\
9 & 5,450 & 5,385 & 4,923 & 1,465 \\
10 & 2,390 & 2,187 & 1,959 & 0 \\
12 & 600 & 600 & 537 & 0 \\
13 & 7,895 & 6,317 & 5,935 & 2,760 \\
14 & 4,000 & 3,978 & 3,668 & 623 \\
Total & 49,235 & 42,621 & 39,712 & 19,495 \\
\hline
\end{tabular}

TABLE 5 Analysis of Concordance between Gross and Microscopic Findings for the Classifications of Lethal $(\mathrm{L})$, Lethal Plus Contributory (LC), and All Observed (LCN) Pathology (percentage of gross diagnoses confirmed by histopathology and number of confirmed events $[n]$ )

\begin{tabular}{|c|c|c|c|c|c|c|}
\hline \multirow[b]{2}{*}{ Tumor Type or Grouping } & \multicolumn{2}{|c|}{$\mathrm{L}$} & \multicolumn{2}{|c|}{$\mathrm{LC}$} & \multicolumn{2}{|c|}{$\mathrm{LCN}$} \\
\hline & $(\%)$ & $n$ & (\%) & $n$ & $(\%)$ & $n$ \\
\hline All primary tumors & $\underline{94.1}$ & 8,828 & $\underline{97.8}$ & 9,177 & $\underline{98.6}$ & 12,222 \\
\hline All connective tissue & $\overline{93.2}$ & 5,540 & $\overline{96.6}$ & 5,740 & $\overline{95.2}$ & 7,346 \\
\hline Lymphoreticular & $\overline{96.7}$ & 4,432 & $\overline{98.0}$ & 4,494 & $\overline{96.0}$ & 5,501 \\
\hline Vascular & $\overline{72.7}$ & 497 & $\overline{89.5}$ & 612 & $\overline{88.5}$ & 1,015 \\
\hline Other connective tissue tumors & 52.4 & 354 & $\overline{58.9}$ & 398 & $\overline{47.7}$ & 605 \\
\hline All epithelial tissue & 76.0 & 2,394 & $\underline{88.9}$ & 2,800 & 89.2 & 7,456 \\
\hline Lung & $\underline{86.9}$ & 1,643 & $\overline{98.0}$ & 1,853 & $\overline{91.7}$ & 5,489 \\
\hline Liver & $\overline{52.6}$ & 170 & $\overline{71.5}$ & 231 & $\overline{60.0}$ & 689 \\
\hline Harderian gland & 78.5 & 142 & $\underline{87.3}$ & 158 & 81.2 & 1,333 \\
\hline Ovary & 23.4 & 68 & 33.8 & 98 & 68.3 & 1,281 \\
\hline $\begin{array}{l}\text { Kidneys, liver, } \\
\text { gastrointestinal, and skin }\end{array}$ & 53.5 & 416 & 69.4 & 540 & 67.5 & 1,681 \\
\hline $\begin{array}{l}\text { Endocrine and } \\
\text { reproductive system }\end{array}$ & 53.3 & 256 & 69.0 & 331 & 70.6 & 1,934 \\
\hline
\end{tabular}


TABLE 6 Analysis of Discordance between Gross and Microscopic Pathology ${ }^{a}$

\begin{tabular}{|c|c|c|c|c|c|c|c|}
\hline \multirow{2}{*}{$\begin{array}{c}\text { Diagnostic } \\
\text { Code, } n, \\
\text { Discordance (\%) }\end{array}$} & \multirow[b]{2}{*}{ CDU } & \multicolumn{3}{|c|}{ Connective Tissue } & \multicolumn{3}{|c|}{ Epithelial Tissue } \\
\hline & & LR & VAS & CON & $A D N$ & LIV & OVE \\
\hline $\mathrm{CDU}, n=1,530$ & 966 & 530 & 68 & 33 & 81 & 14 & 8 \\
\hline 63.1 & 100.0 & 54.9 & 7.0 & 3.4 & 8.4 & 1.4 & 0.8 \\
\hline LR, $n=4,585$ & 67 & 153 & 25 & 4 & 22 & 0 & 2 \\
\hline 3.3 & 43.8 & 100.0 & 16.3 & 2.6 & 14.4 & 0.0 & 1.3 \\
\hline VAS, $n=684$ & 65 & 61 & 187 & 3 & 13 & 9 & 0 \\
\hline 27.3 & 34.8 & 32.6 & 100.0 & 1.6 & 7.0 & 4.8 & 0.0 \\
\hline $\mathrm{CON}, n=676$ & 59 & 54 & 108 & 322 & 24 & 2 & 0 \\
\hline 47.6 & 18.3 & 16.8 & 33.5 & 100.0 & 7.5 & 0.6 & 0.0 \\
\hline $\mathrm{ADN}, n=1,890$ & 42 & 138 & 13 & 9 & 247 & 1 & 1 \\
\hline 13.1 & 17.0 & 55.9 & 5.3 & 3.6 & 100.0 & 0.4 & 0.4 \\
\hline LIV, $n=323$ & 21 & 60 & 37 & 3 & 14 & 153 & 0 \\
\hline 47.4 & 13.7 & 39.2 & 24.2 & 2.0 & 9.2 & 100.0 & 0.0 \\
\hline OVE, $n=290$ & 58 & 52 & 41 & 2 & 6 & 5 & 222 \\
\hline 76.6 & 26.1 & 23.4 & 18.5 & 0.9 & 2.7 & 2.3 & 100.0 \\
\hline
\end{tabular}

a Values on the diagonal (boxed) are the number of discordant events in the diagnostic class stated as $100 \%$. The other values in each row give the number of diagnoses reclassified to another diagnostic code (column) and the percentage of the discordants so reclassified.

Diagnostic codes are as follows:

CDU = Cause of death undetermined

LR = Lymphoreticular tumor

VAS = Vascular tumor

CON = Other connective tissue tumors (fibroma, sarcoma)

$\mathrm{ADN}=$ Lung tumor

LIV = Liver tumor (hepatocellular)

OVE = Ovarian tumor 
TABLE 7 Inventory of Death and Pathology Records for Experiment JM-2

\begin{tabular}{|c|c|c|c|c|c|c|c|c|c|c|c|c|}
\hline \multirow[b]{2}{*}{$\begin{array}{c}\text { Radiation } \\
\text { Quality }\end{array}$} & \multirow[b]{2}{*}{$\begin{array}{l}\text { Total } \\
\text { Dose } \\
\text { (cGy) }\end{array}$} & \multirow[b]{2}{*}{$\begin{array}{c}\text { Treatment } \\
\text { Code }^{\mathrm{a}}\end{array}$} & \multicolumn{5}{|c|}{ Males } & \multicolumn{5}{|c|}{ Females } \\
\hline & & & Input & $\begin{array}{l}\text { Death } \\
\text { Records }\end{array}$ & $\begin{array}{c}\text { MAS }^{b} \\
\pm \mathrm{SE}(\mathrm{d})\end{array}$ & $\begin{array}{l}\text { MACRO } \\
\text { Records }\end{array}$ & $\begin{array}{l}\text { MICRO } \\
\text { Records }\end{array}$ & Input & $\begin{array}{l}\text { Death } \\
\text { Records }\end{array}$ & $\begin{array}{c}\mathrm{MAS}^{\mathbf{b}} \\
\pm \mathrm{SE}(\mathrm{d}) \\
\end{array}$ & $\begin{array}{l}\text { MACRO } \\
\text { Records }\end{array}$ & $\begin{array}{l}\text { MICRO } \\
\text { Records }\end{array}$ \\
\hline \multirow[t]{5}{*}{ Control } & 0 & $\mathrm{AC}$ & 200 & 159 & $835 \pm 15$ & 156 & 123 & 200 & 145 & $863 \pm 15$ & 140 & 124 \\
\hline & & $\mathrm{DC}$ & 200 & 158 & $859 \pm 14$ & 49 & 32 & 200 & 198 & $818 \pm 15$ & 64 & 51 \\
\hline & & EC & 200 & 169 & $864 \pm 15$ & 168 & 137 & 200 & 194 & $832 \pm 13$ & 186 & 165 \\
\hline & & $\mathrm{HC}$ & 200 & 157 & $840 \pm 18$ & 68 & 44 & 200 & 120 & $816 \pm 18$ & 38 & 27 \\
\hline & & so & 200 & 200 & $843 \pm 13$ & 198 & 174 & 200 & 200 & $852 \pm 13$ & 198 & 185 \\
\hline \multirow[t]{12}{*}{$\gamma$ Rays } & 855 & $\mathrm{AI}$ & 200 & 148 & $711 \pm 15$ & 146 & 113 & 200 & 93 & $690 \pm 19$ & 87 & 78 \\
\hline & & BI & 200 & 156 & $691 \pm 14$ & 154 & 132 & 200 & 124 & $673 \pm 16$ & 122 & 112 \\
\hline & & EI & 200 & 151 & $697 \pm 14$ & 149 & 113 & 200 & 121 & $687 \pm 14$ & 117 & 105 \\
\hline & & HI & 200 & 152 & $666 \pm 14$ & 150 & 122 & 200 & 125 & $641 \pm 14$ & 119 & 105 \\
\hline & 1110 & $\mathrm{DI}$ & 200 & 148 & $619 \pm 14$ & 146 & 115 & 200 & 200 & $610 \pm 11$ & 193 & 166 \\
\hline & 90 & $\mathrm{~S} 1$ & 400 & 386 & $810 \pm 10$ & 382 & 328 & 400 & 397 & $790 \pm 9$ & 391 & 367 \\
\hline & 268 & $\mathrm{~S} 2$ & 200 & 185 & $727 \pm 13$ & 179 & 155 & 200 & 198 & $706 \pm 12$ & 193 & 183 \\
\hline & 788 & S3 & 200 & 196 & $460 \pm 17$ & 184 & 133 & 200 & 200 & $431 \pm 17$ & 182 & 136 \\
\hline & 268 & $Y 2^{c}$ & 200 & 200 & $710 \pm 13$ & 192 & 157 & 100 & 99 & $693 \pm 18$ & 95 & 87 \\
\hline & 788 & $\mathrm{Y}^{\mathrm{c}}$ & 200 & 200 & $492 \pm 15$ & 180 & 146 & 100 & 100 & $486 \pm 18$ & 94 & 72 \\
\hline & 268 & $\mathrm{Z2}^{\mathrm{d}}$ & 200 & 193 & $635 \pm 14$ & 189 & 160 & 100 & 100 & $601 \pm 18$ & 94 & 81 \\
\hline & 788 & $\mathrm{Z3}^{\mathrm{d}}$ & 200 & 199 & $520 \pm 13$ & 181 & 147 & 95 & 95 & $498 \pm 18$ & 92 & 71 \\
\hline \multirow[t]{12}{*}{ Neutrons } & 240 & $\mathrm{AI}$ & 200 & 151 & $546 \pm 16$ & 148 & 118 & 200 & 108 & $505 \pm 15$ & 99 & 81 \\
\hline & & $\mathrm{BI}$ & 200 & 134 & $518 \pm 14$ & 130 & 101 & 200 & 121 & $499 \pm 13$ & 111 & 97 \\
\hline & & EI & 200 & 149 & $544 \pm 14$ & 147 & 119 & 200 & 128 & $495 \pm 12$ & 118 & 100 \\
\hline & & $\mathrm{HI}$ & 200 & 149 & $572 \pm 14$ & 144 & 124 & 200 & 136 & $528 \pm 12$ & 131 & 110 \\
\hline & 80 & DI & 200 & 149 & $666 \pm 15$ & 146 & 115 & 200 & 167 & $675 \pm 13$ & 163 & 147 \\
\hline & 20 & $\mathrm{~S} 1$ & 400 & 383 & $789 \pm 10$ & 382 & 335 & 400 & 380 & $759 \pm 10$ & 366 & 343 \\
\hline & 80 & $\mathrm{~S} 2$ & 200 & 178 & $724 \pm 14$ & 175 & 157 & 200 & 200 & $667 \pm 14$ & 185 & 173 \\
\hline & 240 & S3 & 200 & 157 & $632 \pm 15$ & 154 & 135 & 200 & 199 & $580 \pm 13$ & 187 & 167 \\
\hline & 80 & $\mathrm{Y}^{\mathrm{c}}$ & 200 & 200 & $693 \pm 15$ & 197 & 169 & 100 & 100 & $655 \pm 18$ & 93 & 83 \\
\hline & 240 & $\mathrm{Y}^{\mathrm{c}}$ & 200 & 199 & $612 \pm 13$ & 184 & 161 & 100 & 99 & $593 \pm 15$ & 96 & 84 \\
\hline & 80 & $\mathrm{Z2}^{\mathrm{d}}$ & 200 & 199 & $609 \pm 12$ & 193 & 159 & 95 & 95 & $600 \pm 18$ & 91 & 76 \\
\hline & 240 & $\mathrm{Z3}^{\mathrm{d}}$ & 200 & 200 & $570 \pm 13$ & 193 & 153 & 100 & 100 & $573 \pm 16$ & 96 & 85 \\
\hline
\end{tabular}

a See Appendix $J$ for details.

b Mean after-survival [MAS] values based on all death records.

c 194 days of age at exposure.

d 287 days of age at exposure. 
TABLE 8 Inventory of Death and Pathology Records for Experiment JM-3

\begin{tabular}{|c|c|c|c|c|c|c|c|c|c|c|c|c|}
\hline \multirow[b]{2}{*}{$\begin{array}{c}\text { Radiation } \\
\text { Quality }\end{array}$} & \multirow[b]{2}{*}{$\begin{array}{l}\text { Total } \\
\text { Dose } \\
\text { (cGy) }\end{array}$} & \multirow[b]{2}{*}{$\begin{array}{c}\text { Treatment } \\
\text { Code }^{\mathrm{a}}\end{array}$} & \multicolumn{5}{|c|}{ Males } & \multicolumn{5}{|c|}{ Females } \\
\hline & & & Input & $\begin{array}{c}\text { Death } \\
\text { Records }\end{array}$ & $\begin{array}{c}\text { MAS }^{b} \\
\pm \mathrm{SE} \text { (d) }\end{array}$ & $\begin{array}{l}\text { MACRO } \\
\text { Records }\end{array}$ & $\begin{array}{l}\text { MICRO } \\
\text { Records }\end{array}$ & Input & $\begin{array}{c}\text { Death } \\
\text { Records }\end{array}$ & $\begin{array}{c}\text { MAS }^{b} \\
\pm \mathrm{SE}(\mathrm{d})\end{array}$ & $\begin{array}{l}\text { MACRO } \\
\text { Records }\end{array}$ & $\begin{array}{l}\text { MICRO } \\
\text { Records }\end{array}$ \\
\hline Control & 0 & so & 200 & 200 & $872 \pm 13$ & 191 & 142 & 200 & 190 & $820 \pm 16$ & 175 & 152 \\
\hline \multirow[t]{5}{*}{$\gamma$ Rays } & 90 & S4 & 200 & 199 & $858 \pm 14$ & 189 & 138 & 200 & 200 & $825 \pm 13$ & 189 & 171 \\
\hline & 143 & S5 & 160 & 160 & $827 \pm 16$ & 150 & 113 & 80 & 7 & -c & 7 & 6 \\
\hline & 206 & S6 & 160 & 160 & $802 \pm 16$ & 155 & 122 & 80 & 6 & $-c$ & 6 & 4 \\
\hline & 417 & S7 & 120 & 120 & $744 \pm 18$ & 117 & 102 & 60 & 60 & $706 \pm 27$ & 54 & 49 \\
\hline & 569 & S8 & 120 & 120 & $646 \pm 20$ & 118 & 99 & 120 & 78 & $645 \pm 25$ & 74 & 66 \\
\hline \multirow[t]{7}{*}{ Neutrons } & 20 & S4 & 250 & 249 & $826 \pm 13$ & 242 & 189 & 250 & 244 & $778 \pm 13$ & 231 & 208 \\
\hline & 40 & S6 & 200 & 199 & $798 \pm 14$ & 181 & 153 & 80 & 7 & $-c$ & 6 & 5 \\
\hline & 60 & S6 & 200 & 200 & $780 \pm 14$ & 191 & 169 & 80 & 7 & $-^{c}$ & 7 & 7 \\
\hline & 120 & S7 & 120 & 120 & $719 \pm 18$ & 117 & 104 & 60 & 7 & $-^{\mathbf{c}}$ & 7 & 5 \\
\hline & 160 & S8 & 120 & 119 & $714 \pm 18$ & 115 & 101 & 120 & 120 & $646 \pm 17$ & 117 & 99 \\
\hline & 240 & SL & 50 & 60 & $678 \pm 25$ & 49 & 0 & 0 & & & & \\
\hline & 240 & SH & 50 & 45 & $702 \pm 25$ & 44 & 0 & 0 & & & & \\
\hline
\end{tabular}

a See Appendix $J$ for details.

b MAS values based on all death records.

c Females discarded before about $500 \mathrm{~d}$ after exposure. 
TABLE 9 Inventory of Death and Pathology Records for Experiments JM-4K and JM-4W

\begin{tabular}{|c|c|c|c|c|c|c|c|c|c|c|c|c|}
\hline \multirow[b]{2}{*}{$\begin{array}{c}\text { Radiation } \\
\text { Quality }\end{array}$} & \multirow[b]{2}{*}{$\begin{array}{l}\text { Total } \\
\text { Dose } \\
\text { (cGy) }\end{array}$} & \multirow[b]{2}{*}{$\begin{array}{l}\text { Treatment } \\
\text { Code }\end{array}$} & \multicolumn{5}{|c|}{ Males } & \multicolumn{5}{|c|}{ Females } \\
\hline & & & Input & $\begin{array}{c}\text { Death } \\
\text { Records }\end{array}$ & $\begin{array}{c}\mathrm{MAS}^{\mathrm{b}} \\
\pm \mathrm{SE}(\mathrm{d})\end{array}$ & $\begin{array}{l}\text { MACRO } \\
\text { Records }\end{array}$ & $\begin{array}{l}\text { MICRO } \\
\text { Records }\end{array}$ & Input & $\begin{array}{l}\text { Death } \\
\text { Records }\end{array}$ & $\begin{array}{c}\text { MAS }^{b} \\
\pm \mathrm{SE} \text { (d) }\end{array}$ & $\begin{array}{l}\text { MACRO } \\
\text { Records }\end{array}$ & $\begin{array}{l}\text { MICRO } \\
\text { Records }\end{array}$ \\
\hline \multicolumn{13}{|l|}{ JM-4K: } \\
\hline Control & 0 & KO & 280 & 195 & $928 \pm 16$ & 186 & 129 & 180 & 140 & $890 \pm 16$ & 134 & 110 \\
\hline \multirow[t]{6}{*}{$\gamma$ Rays } & 206 & K1 & 675 & 598 & $854 \pm 8$ & 585 & 391 & 120 & 7 & $-^{\mathrm{c}}$ & 7 & 0 \\
\hline & 417 & $\mathrm{~K} 2$ & 455 & 400 & $802 \pm 9$ & 385 & 278 & 400 & 394 & $783 \pm 9$ & 378 & 329 \\
\hline & 959 & K3 & 275 & 194 & $725 \pm 12$ & 185 & 146 & 80 & 5 & - & 5 & 0 \\
\hline & 1919 & $\mathrm{~K} 4$ & 225 & 150 & $441 \pm 12$ & 143 & 105 & 60 & 13 & - & 12 & 0 \\
\hline & 3820 & $\mathrm{~K} 5$ & 190 & 147 & $269 \pm 7$ & 117 & 48 & 30 & 25 & $244 \pm 12$ & 23 & 0 \\
\hline & 5111 & K6 & 140 & 100 & $143 \pm 3$ & 50 & 0 & 40 & 40 & $112 \pm 2$ & 28 & 0 \\
\hline \multirow[t]{6}{*}{ Neutrons } & 20 & K1 & 675 & 593 & $846 \pm 8$ & 563 & 328 & 600 & 693 & $800 \pm 8$ & 578 & 496 \\
\hline & 40 & K2 & 475 & 400 & $799 \pm 10$ & 378 & 259 & 80 & 3 & - & 3 & 0 \\
\hline & 60 & K3 & 275 & 194 & $762 \pm 15$ & 184 & 139 & 40 & 0 & - & 0 & 0 \\
\hline & 120 & K4 & 225 & 150 & $666 \pm 16$ & 145 & 121 & 30 & 0 & - & 0 & 0 \\
\hline & 168 & $\mathrm{~K} 5$ & 190 & 150 & $631 \pm 15$ & 141 & 110 & 150 & 150 & $596 \pm 13$ & 144 & 127 \\
\hline & 320 & KK6 & 140 & 95 & $511 \pm 16$ & 90 & 77 & 20 & 3 & - & 2 & 0 \\
\hline \multicolumn{13}{|l|}{ JM-4W: } \\
\hline Control & 0 & Wo & 0 & & & & & 400 & 324 & $853 \pm 11$ & 314 & 0 \\
\hline \multirow[t]{2}{*}{$\gamma$ Rays } & 807 & W1 & 0 & & & & & 450 & 307 & $703 \pm 9$ & 302 & 0 \\
\hline & 2690 & W2 & 0 & & & & & 500 & 333 & $351 \pm 7$ & 304 & 0 \\
\hline \multirow[t]{2}{*}{ Neutrons } & 80 & W1 & 0 & & & & & 400 & 263 & $695 \pm 10$ & 261 & 0 \\
\hline & 240 & W2 & 0 & & & & & 450 & 292 & $554 \pm 10$ & 281 & 0 \\
\hline
\end{tabular}

a See Appendix J for details.

b MAS values based on all death records.

c Dash indicates a number of deaths too small to allow estimation of MAS. 
TABLE 10 Inventory of Death and Pathology Records for Experiments JM-4L1 and JM-4L2 (only males used)

\begin{tabular}{cccccccc}
\hline $\begin{array}{c}\text { Radiation } \\
\text { Quality }\end{array}$ & $\begin{array}{c}\text { Total } \\
\text { Dose } \\
\text { (cGy) }\end{array}$ & $\begin{array}{c}\text { Treatment } \\
\text { Code }^{\text {a }}\end{array}$ & $\begin{array}{c}\text { Death } \\
\text { Input }\end{array}$ & $\begin{array}{c}\text { MAS }^{\mathrm{b}} \\
\text { Records } \\
\pm \text { SE (d) }\end{array}$ & $\begin{array}{c}\text { MACRO } \\
\text { Records }\end{array}$ & $\begin{array}{c}\text { MICRO } \\
\text { Records }\end{array}$ \\
\hline JM-4L1: & & & & & & & \\
Control & 0 & L0 & 200 & 189 & $862 \pm 15$ & 181 & 111 \\
$\gamma$ Rays & 206 & L1 & 200 & 194 & $830 \pm 13$ & 180 & 118 \\
& 417 & L2 & 100 & 99 & $806 \pm 22$ & 97 & 57 \\
& 959 & L3 & 80 & 76 & $675 \pm 23$ & 72 & 48 \\
& 1918 & L4 & 40 & 40 & $579 \pm 32$ & 37 & 30 \\
JM-4L2: & & & & & & & \\
Control & 0 & LC & 175 & 173 & $803 \pm 16$ & 172 & 120 \\
& & & & & & & \\
$\gamma$ Rays & 529 & L5 & 175 & 170 & $767 \pm 15$ & 165 & 121 \\
& 1070 & L6 & 100 & 99 & $719 \pm 16$ & 99 & 79 \\
& 2460 & L7 & 75 & 74 & $608 \pm 22$ & 72 & 51 \\
\hline
\end{tabular}

a See Appendix J for details.

b MAS values based on all death records. 
TABLE 11 Inventory of Death and Pathology Records for Experiment JM-7

\begin{tabular}{|c|c|c|c|c|c|c|c|c|c|c|c|c|}
\hline \multirow[b]{2}{*}{$\begin{array}{c}\text { Radiation } \\
\text { Quality }\end{array}$} & \multirow[b]{2}{*}{$\begin{array}{l}\text { Total } \\
\text { Dose } \\
\text { (cGy) }\end{array}$} & \multirow[b]{2}{*}{$\begin{array}{l}\text { Treatment } \\
\text { Code }^{\mathrm{a}}\end{array}$} & \multicolumn{5}{|c|}{ Males } & \multicolumn{5}{|c|}{ Females } \\
\hline & & & Input & $\begin{array}{l}\text { Death } \\
\text { Records }\end{array}$ & $\begin{array}{c}\text { MAS }^{b} \\
\pm \text { SE (d) }\end{array}$ & $\begin{array}{l}\text { MACRO } \\
\text { Records }\end{array}$ & $\begin{array}{l}\text { MICRO } \\
\text { Records }\end{array}$ & Input & $\begin{array}{l}\text { Death } \\
\text { Records }\end{array}$ & $\begin{array}{c}\text { MAS }^{\mathrm{b}} \\
\pm \mathrm{SE} \text { (d) }\end{array}$ & $\begin{array}{l}\text { MACRO } \\
\text { Records }\end{array}$ & $\begin{array}{l}\text { MICRO } \\
\text { Records }\end{array}$ \\
\hline Control & 0 & 00 & 330 & 310 & $887 \pm 11$ & 293 & 0 & 180 & 175 & $886 \pm 15$ & 164 & 0 \\
\hline$\gamma$ Rays & $\begin{array}{r}417 \\
1918\end{array}$ & $\begin{array}{l}\text { Q1 } \\
\text { Q2 }\end{array}$ & $\begin{array}{l}135 \\
180\end{array}$ & $\begin{array}{l}135 \\
178\end{array}$ & $\begin{array}{l}862 \pm 16 \\
627 \pm 12\end{array}$ & $\begin{array}{l}131 \\
167\end{array}$ & $\begin{array}{r}92 \\
124\end{array}$ & $\begin{array}{r}30 \\
180\end{array}$ & $\begin{array}{r}27 \\
178\end{array}$ & $\begin{array}{l}786 \pm 41 \\
621 \pm 10\end{array}$ & $\begin{array}{r}25 \\
166\end{array}$ & $\begin{array}{l}0 \\
0\end{array}$ \\
\hline Neutrons & $\begin{array}{r}40 \\
160\end{array}$ & $\begin{array}{l}\mathrm{Q} 1 \\
\mathrm{Q} 2\end{array}$ & $\begin{array}{l}150 \\
200\end{array}$ & $\begin{array}{l}146 \\
189\end{array}$ & $\begin{array}{l}789 \pm 15 \\
632 \pm 12\end{array}$ & $\begin{array}{l}138 \\
180\end{array}$ & $\begin{array}{r}95 \\
127\end{array}$ & $\begin{array}{r}30 \\
200\end{array}$ & $\begin{array}{r}30 \\
194\end{array}$ & $\begin{array}{l}763 \pm 38 \\
599 \pm 11\end{array}$ & $\begin{array}{r}29 \\
187\end{array}$ & $\begin{array}{l}0 \\
0\end{array}$ \\
\hline$\gamma$ Rays & $\begin{array}{l}206 \\
569\end{array}$ & $\begin{array}{l}\mathrm{R} 1^{\mathrm{c}} \\
\mathrm{R2^{ \textrm {c } }}\end{array}$ & $\begin{array}{l}150 \\
180\end{array}$ & $\begin{array}{l}148 \\
178\end{array}$ & $\begin{array}{l}460 \pm 14 \\
392 \pm 11\end{array}$ & $\begin{array}{l}147 \\
168\end{array}$ & $\begin{array}{l}0 \\
0\end{array}$ & $\begin{array}{r}50 \\
180\end{array}$ & $\begin{array}{r}50 \\
176\end{array}$ & $\begin{array}{l}408 \pm 24 \\
374 \pm 12\end{array}$ & $\begin{array}{r}47 \\
175\end{array}$ & $\begin{array}{l}0 \\
0\end{array}$ \\
\hline Neutrons & $\begin{array}{r}40 \\
160\end{array}$ & $\begin{array}{l}\mathrm{R} 1^{\mathrm{c}} \\
\mathrm{R} 2^{\mathrm{c}}\end{array}$ & $\begin{array}{l}150 \\
180\end{array}$ & $\begin{array}{l}150 \\
172\end{array}$ & $\begin{array}{l}429 \pm 13 \\
410 \pm 11\end{array}$ & $\begin{array}{l}147 \\
174\end{array}$ & $\begin{array}{l}0 \\
0\end{array}$ & $\begin{array}{r}50 \\
180\end{array}$ & $\begin{array}{r}49 \\
177\end{array}$ & $\begin{array}{l}434 \pm 23 \\
395 \pm 12\end{array}$ & $\begin{array}{r}46 \\
170\end{array}$ & $\begin{array}{l}0 \\
0\end{array}$ \\
\hline
\end{tabular}

a See Appendix J for details.

b MAS values based on all death records.

c $515 \mathrm{~d}$ of age at exposure to the single dose indicated. 
TABLE 12 Inventory of Death and Pathology Records for Experiment JM-8

\begin{tabular}{|c|c|c|c|c|c|c|c|c|c|c|c|c|}
\hline \multirow[b]{2}{*}{$\begin{array}{c}\text { Radiation } \\
\text { Quality }\end{array}$} & \multirow[b]{2}{*}{$\begin{array}{c}\text { Dose } \\
\text { per Week } \\
\text { (cGy) }\end{array}$} & \multirow[b]{2}{*}{$\begin{array}{l}\text { Treatment } \\
\text { Code }^{\mathrm{a}}\end{array}$} & \multicolumn{5}{|c|}{ Males } & \multicolumn{5}{|c|}{ Females } \\
\hline & & & Input & $\begin{array}{l}\text { Death } \\
\text { Records }\end{array}$ & $\begin{array}{c}\mathrm{MAS}^{\mathrm{b}} \\
\pm \mathrm{SE} \text { (d) }\end{array}$ & $\begin{array}{l}\text { MACRO } \\
\text { Records }\end{array}$ & $\begin{array}{l}\text { MICRO } \\
\text { Records }\end{array}$ & Input & $\begin{array}{l}\text { Death } \\
\text { Records }\end{array}$ & $\begin{array}{c}\text { MAS }^{b} \\
\pm S E(d)\end{array}$ & $\begin{array}{l}\text { MACRO } \\
\text { Records }\end{array}$ & $\begin{array}{l}\text { MICRO } \\
\text { Records }\end{array}$ \\
\hline \multicolumn{13}{|l|}{ Control } \\
\hline & 0 & UO & 140 & 60 & $904 \pm 25$ & 54 & 40 & 50 & 50 & $853 \pm 22$ & 44 & 39 \\
\hline \multirow[t]{3}{*}{$\gamma$ Rays } & 6.95 & U1 & 260 & 181 & $819 \pm 13$ & 170 & 56 & 180 & 174 & $819 \pm 13$ & 158 & 0 \\
\hline & 17.4 & U2 & 200 & 120 & $755 \pm 15$ & 115 & 43 & 20 & 20 & $670 \pm 35$ & 15 & 0 \\
\hline & 31.9 & U3 & 170 & 86 & $631 \pm 14$ & 79 & 0 & 15 & 15 & $603 \pm 37$ & 13 & 0 \\
\hline \multirow[t]{3}{*}{ Neutrons } & 0.67 & U1 & 260 & 179 & $783 \pm 14$ & 169 & 61 & 180 & 169 & $737 \pm 13$ & 158 & 0 \\
\hline & 1.67 & U2 & 200 & 112 & $680 \pm 13$ & 105 & 0 & 20 & 20 & $608 \pm 36$ & 19 & 0 \\
\hline & 2.67 & U3 & 170 & 91 & $644 \pm 17$ & 85 & 0 & 15 & 15 & $653 \pm 32$ & 13 & 0 \\
\hline
\end{tabular}

a See Appendix J for details.

b MAS values based on all death records. 
TABLE 13 Inventory of Death and Pathology Records for Experiment JM-9

\begin{tabular}{|c|c|c|c|c|c|c|c|c|c|c|c|c|}
\hline \multirow[b]{2}{*}{$\begin{array}{c}\text { Radiation } \\
\text { Quality }\end{array}$} & \multirow[b]{2}{*}{$\begin{array}{l}\text { Total } \\
\text { Dose } \\
\text { (cGy) }\end{array}$} & \multirow[b]{2}{*}{$\begin{array}{c}\text { Treatment } \\
\text { Code }^{\mathrm{a}}\end{array}$} & \multicolumn{5}{|c|}{ Males } & \multicolumn{5}{|c|}{ Females } \\
\hline & & & Input & $\begin{array}{l}\text { Death } \\
\text { Records }\end{array}$ & $\begin{array}{l}\mathrm{MAS}^{\mathrm{b}} \\
\pm \mathrm{SE}(\mathrm{d}) \\
\end{array}$ & $\begin{array}{r}\text { MACRO } \\
\text { Records } \\
\end{array}$ & $\begin{array}{l}\text { MICRO } \\
\text { Records }\end{array}$ & Input & $\begin{array}{c}\text { Death } \\
\text { Records }\end{array}$ & $\begin{array}{l}\mathrm{MAS}^{\mathrm{b}} \\
\pm \mathrm{SE}(\mathrm{d}) \\
\end{array}$ & $\begin{array}{l}\text { MACRO } \\
\text { Records } \\
\end{array}$ & $\begin{array}{l}\text { MICRO } \\
\text { Records } \\
\end{array}$ \\
\hline \multicolumn{13}{|l|}{$\begin{array}{l}\text { Preliminary } \\
\text { study: }\end{array}$} \\
\hline Control & 0 & $\begin{array}{l}\mathrm{X} 0 \\
\mathrm{XX}\end{array}$ & $\begin{array}{r}200 \\
0\end{array}$ & 200 & $935 \pm 13$ & 189 & 0 & $\begin{array}{l}200 \\
200\end{array}$ & $\begin{array}{l}199 \\
200\end{array}$ & $\begin{array}{l}891 \pm 14 \\
865 \pm 13\end{array}$ & $\begin{array}{l}184 \\
186\end{array}$ & $\begin{array}{l}0 \\
0\end{array}$ \\
\hline Neutrons & $\begin{array}{r}5 \\
10\end{array}$ & $\begin{array}{l}\mathrm{X} 2 \\
\mathrm{X} 3\end{array}$ & $\begin{array}{r}0 \\
200\end{array}$ & 200 & $876 \pm 14$ & 193 & 0 & $\begin{array}{l}300 \\
200\end{array}$ & $\begin{array}{l}289 \\
200\end{array}$ & $\begin{array}{l}850 \pm 12 \\
827 \pm 13\end{array}$ & $\begin{array}{l}261 \\
188\end{array}$ & $\begin{array}{l}0 \\
0\end{array}$ \\
\hline & 10 & $\mathrm{xx}$ & 0 & & & & & 200 & 197 & $846 \pm 15$ & 183 & 0 \\
\hline \multicolumn{13}{|l|}{ Final study: } \\
\hline Control & 0 & $\mathrm{XC}$ & 0 & & & & & 750 & 739 & $856 \pm 7$ & 656 & 248 \\
\hline$\gamma$ Rays & $\begin{array}{l}22.5 \\
45 \\
90\end{array}$ & $\begin{array}{l}\mathrm{X} 1 \\
\mathrm{X} 2 \\
\mathrm{X} 3\end{array}$ & $\begin{array}{l}0 \\
0 \\
0\end{array}$ & & & & & $\begin{array}{l}500 \\
350 \\
200\end{array}$ & $\begin{array}{l}497 \\
346 \\
194\end{array}$ & $\begin{array}{l}844 \pm 9 \\
850 \pm 11 \\
819 \pm 14\end{array}$ & $\begin{array}{l}453 \\
314 \\
177\end{array}$ & $\begin{array}{r}177 \\
121 \\
73\end{array}$ \\
\hline Neutrons & $\begin{array}{l}1 \\
2.5 \\
5 \\
10 \\
20 \\
40\end{array}$ & $\begin{array}{l}X 4 \\
X 5 \\
X 6 \\
X 7 \\
X 8 \\
X 9\end{array}$ & $\begin{array}{l}0 \\
0 \\
0 \\
0 \\
0 \\
0\end{array}$ & & & & & $\begin{array}{l}750 \\
450 \\
350 \\
250 \\
200 \\
150\end{array}$ & $\begin{array}{l}735 \\
445 \\
349 \\
245 \\
200 \\
150 \\
\end{array}$ & $\begin{array}{l}859 \pm 7 \\
848 \pm 9 \\
822 \pm 11 \\
805 \pm 13 \\
797 \pm 13 \\
753 \pm 16\end{array}$ & $\begin{array}{l}661 \\
411 \\
312 \\
230 \\
183 \\
142 \\
\end{array}$ & $\begin{array}{r}253 \\
169 \\
132 \\
91 \\
78 \\
123 \\
\end{array}$ \\
\hline
\end{tabular}

a See Appendix $\mathrm{J}$ for details.

b MAS values based on all death records. 
TABLE 14 Inventory of Death and Pathology Records for Experiment JM-10 (males only)

\begin{tabular}{lccccccc}
\hline $\begin{array}{c}\text { Radiation } \\
\text { Quality }\end{array}$ & $\begin{array}{c}\text { Total } \\
\text { Dose } \\
\text { (cGy) }\end{array}$ & $\begin{array}{c}\text { Treatment } \\
\text { Code }^{\mathrm{a}}\end{array}$ & Input & $\begin{array}{c}\text { Death } \\
\text { Records }\end{array}$ & $\begin{array}{c}\text { MAS } \\
\pm \text { SE (d) }\end{array}$ & $\begin{array}{c}\text { MACRO } \\
\text { Records }\end{array}$ & $\begin{array}{c}\text { MICRO } \\
\text { Records }\end{array}$ \\
\hline \multirow{2}{*}{ Control } & 0 & V0 & 245 & 211 & $1255 \pm 35$ & 181 & 0 \\
& 0 & W0 & 210 & 203 & $1321 \pm 33$ & 171 & 0 \\
$\gamma$ Rays & 90 & V1 & 200 & 189 & $1225 \pm 38$ & 164 & 0 \\
& 143 & V2 & 200 & 182 & $1211 \pm 36$ & 158 & 0 \\
& 206 & V3 & 200 & 190 & $1185 \pm 35$ & 175 & 0 \\
& 417 & V4 & 170 & 159 & $1027 \pm 35$ & 146 & 0 \\
& & & & & & & \\
& & & & & & & \\
& 20 & V1 & 200 & 182 & $1183 \pm 34$ & 161 & 0 \\
& 40 & V2 & 200 & 180 & $1179 \pm 30$ & 167 & 0 \\
& 80 & V3 & 150 & 141 & $979 \pm 31$ & 121 & 0 \\
& 160 & V4 & 150 & 140 & $890 \pm 25$ & 129 & 0 \\
& 40 & VV & 250 & 219 & $1151 \pm 29$ & 203 & 0 \\
& 160 & VW & 215 & 191 & $841 \pm 22$ & 183 & 0 \\
\hline
\end{tabular}

a See Appendix J for details.

b MAS values based on all death records.

TABLE 15 Inventory of Death and Pathology Records for Experiment JM-12

\begin{tabular}{lccccccc}
\hline $\begin{array}{c}\text { Radiation } \\
\text { Quality }\end{array}$ & $\begin{array}{c}\text { Total } \\
\text { Dose } \\
\text { (cGy) }\end{array}$ & $\begin{array}{c}\text { Treatment } \\
\text { Code }^{\mathrm{a}}\end{array}$ & Input & $\begin{array}{c}\text { Death } \\
\text { Records }\end{array}$ & $\begin{array}{c}\text { MAS }^{\mathrm{b}} \\
\pm \text { SE (d) }\end{array}$ & $\begin{array}{c}\text { MACRO } \\
\text { Records }\end{array}$ & $\begin{array}{c}\text { MICRO } \\
\text { Records }\end{array}$ \\
\hline \multirow{2}{*}{ Control } & 0 & J0 & 120 & 120 & $904 \pm 19$ & 112 & 0 \\
Neutrons & 240 & J1 & 120 & 120 & $668 \pm 18$ & 98 & 0 \\
& 240 & J2 & 120 & 120 & $620 \pm 21$ & 112 & 0 \\
& 240 & J4 & 120 & 120 & $548 \pm 22$ & 105 & 0 \\
& 240 & J6 & 120 & 120 & $601 \pm 19$ & 110 & 0 \\
\hline
\end{tabular}

a See Appendix $\mathrm{J}$ for details.

b MAS values based on all death records. 
TABLE 16 Inventory of Death and Pathology Records for Experiment JM-13

\begin{tabular}{|c|c|c|c|c|c|c|c|c|c|c|c|c|}
\hline \multirow[b]{2}{*}{$\begin{array}{c}\text { Radiation } \\
\text { Quality }\end{array}$} & \multirow[b]{2}{*}{$\begin{array}{l}\text { Total } \\
\text { Dose } \\
\text { (cGy) }\end{array}$} & \multirow[b]{2}{*}{$\begin{array}{c}\text { Treatment } \\
\text { Code }^{\mathrm{a}}\end{array}$} & \multicolumn{5}{|c|}{ Males } & \multicolumn{5}{|c|}{ Females } \\
\hline & & & Input & $\begin{array}{l}\text { Death } \\
\text { Records }\end{array}$ & $\begin{array}{c}\text { MAS }^{b} \\
\pm \text { SE (d) }\end{array}$ & $\begin{array}{l}\text { MACRO } \\
\text { Records }\end{array}$ & $\begin{array}{l}\text { MICRO } \\
\text { Records }\end{array}$ & Input & $\begin{array}{c}\text { Death } \\
\text { Records }\end{array}$ & $\begin{array}{c}\text { MAS }^{b} \\
\pm \mathrm{SE}(\mathrm{d})\end{array}$ & $\begin{array}{l}\text { MACRO } \\
\text { Records }\end{array}$ & $\begin{array}{l}\text { MICRO } \\
\text { Records }\end{array}$ \\
\hline Control & 0 & $0 \mathrm{X}$ & 810 & 592 & $882 \pm 8$ & 565 & 196 & 600 & 584 & $873 \pm 8$ & 541 & 214 \\
\hline \multirow[t]{5}{*}{$\gamma$ Rays } & 100 & $1 X$ & 600 & 594 & $861 \pm 7$ & 571 & 212 & 600 & 598 & $846 \pm 8$ & 562 & 223 \\
\hline & 200 & $2 X$ & 220 & 178 & $840 \pm 14$ & 168 & 115 & 180 & 174 & $819 \pm 15$ & 167 & 127 \\
\hline & 300 & $3 \mathrm{X}$ & 295 & 83 & $832 \pm 20$ & 79 & 57 & 80 & 79 & $782 \pm 20$ & 76 & 59 \\
\hline & 460 & $4 X$ & 290 & 86 & $813 \pm 19$ & 83 & 62 & 80 & 75 & $784 \pm 18$ & 70 & 57 \\
\hline & 600 & $5 X$ & 290 & 90 & $793 \pm 20$ & 85 & 56 & 80 & 79 & $745 \pm 19$ & 74 & 59 \\
\hline \multirow[t]{6}{*}{ Neutrons } & 2 & $1 \mathrm{X}$ & 600 & 566 & $893 \pm 8$ & 538 & 174 & 600 & 568 & $869 \pm 8$ & 528 & 218 \\
\hline & 7.5 & $2 X$ & 455 & 271 & $869 \pm 11$ & 255 & 94 & 250 & 247 & $837 \pm 12$ & 215 & 95 \\
\hline & 13.5 & $3 \mathrm{X}$ & 250 & 242 & $855 \pm 11$ & 230 & 78 & 250 & 237 & $809 \pm 11$ & 221 & 104 \\
\hline & 21 & $4 X$ & 450 & 254 & $817 \pm 12$ & 231 & 94 & 250 & 244 & $790 \pm 12$ & 230 & 111 \\
\hline & 30 & $5 \mathrm{X}$ & 150 & 149 & $779 \pm 16$ & 141 & 102 & 150 & 150 & $771 \pm 15$ & 142 & 121 \\
\hline & 40 & $6 \mathrm{X}$ & 285 & 98 & $805 \pm 18$ & 95 & 67 & 80 & 79 & $717 \pm 19$ & 78 & 65 \\
\hline
\end{tabular}

a See Appendix $\mathbf{J}$ for details.

b MAS values based on all death records. 
TABLE 17 Inventory of Death and Pathology Records for Experiment JM-14

\begin{tabular}{|c|c|c|c|c|c|c|c|c|c|c|c|c|}
\hline \multirow[b]{2}{*}{$\begin{array}{c}\text { Radiation } \\
\text { Quality }\end{array}$} & \multirow[b]{2}{*}{$\begin{array}{l}\text { Total } \\
\text { Dose } \\
\text { (cGy) }\end{array}$} & \multirow[b]{2}{*}{$\begin{array}{l}\text { Treatment } \\
\text { Code }^{\mathrm{a}}\end{array}$} & \multicolumn{5}{|c|}{ Males } & \multicolumn{5}{|c|}{ Females } \\
\hline & & & Input & $\begin{array}{l}\text { Death } \\
\text { Records }\end{array}$ & $\begin{array}{c}\text { MAS }^{\mathrm{b}} \\
\pm \mathrm{SE} \text { (d) }\end{array}$ & $\begin{array}{l}\text { MACRO } \\
\text { Records }\end{array}$ & $\begin{array}{l}\text { MICRO } \\
\text { Records }\end{array}$ & Input & $\begin{array}{c}\text { Death } \\
\text { Records }\end{array}$ & $\begin{array}{c}\mathrm{MAS}^{\mathrm{b}} \\
\pm \mathrm{SE} \text { (d) }\end{array}$ & $\begin{array}{l}\text { MACRO } \\
\text { Records }\end{array}$ & $\begin{array}{l}\text { MICRO } \\
\text { Records }\end{array}$ \\
\hline \multirow[t]{2}{*}{ Control } & 0 & $\mathrm{OP}^{\mathrm{c}}$ & 200 & 194 & $886 \pm 13$ & 173 & 0 & 200 & 199 & $858 \pm 13$ & 182 & 0 \\
\hline & & $0 S^{d}$ & 200 & 199 & $891 \pm 13$ & 189 & 0 & 200 & 200 & $858 \pm 14$ & 188 & 0 \\
\hline \multirow[t]{3}{*}{$\gamma$ Rays } & 206 & $\mathrm{Co}^{\Theta}$ & 200 & 199 & $790 \pm 14$ & 184 & 0 & 200 & 198 & $770 \pm 13$ & 186 & 157 \\
\hline & 206 & $\mathrm{CP}$ & 200 & 198 & $821 \pm 14$ & 182 & 0 & 200 & 200 & $824 \pm 13$ & 180 & 161 \\
\hline & 417 & DP & 200 & 199 & $796 \pm 15$ & 182 & 0 & 200 & 200 & $738 \pm 13$ & 192 & 0 \\
\hline \multirow[t]{5}{*}{ Neutrons } & 10 & AO & 200 & 198 & $850 \pm 13$ & 180 & 0 & 200 & 199 & $812 \pm 14$ & 182 & 156 \\
\hline & 10 & AP & 200 & 199 & $843 \pm 16$ & 183 & 0 & 200 & 199 & $836 \pm 14$ & 186 & 149 \\
\hline & 10 & $\mathrm{AR}^{f}$ & 200 & 200 & $874 \pm 14$ & 186 & 0 & 200 & 200 & $836 \pm 13$ & 184 & 0 \\
\hline & 40 & BP & 200 & 199 & $797 \pm 14$ & 183 & 0 & 200 & 200 & $762 \pm 13$ & 186 & 0 \\
\hline & 40 & BR & 200 & 200 & $797 \pm 14$ & 182 & 0 & 200 & 198 & $751 \pm 13$ & 178 & 0 \\
\hline
\end{tabular}

a See Appendix J for details.

b MAS values based on all death records.

c Code P: treated with radioprotector WR-2721.

d Code S: treated with saline.

- Code 0: no treatment.

f Code R: treated with radioprotector WR-151327. 
A-1

APPENDIX A:

JANUS DEATH TAG AND CAGE CARD 
A-2 


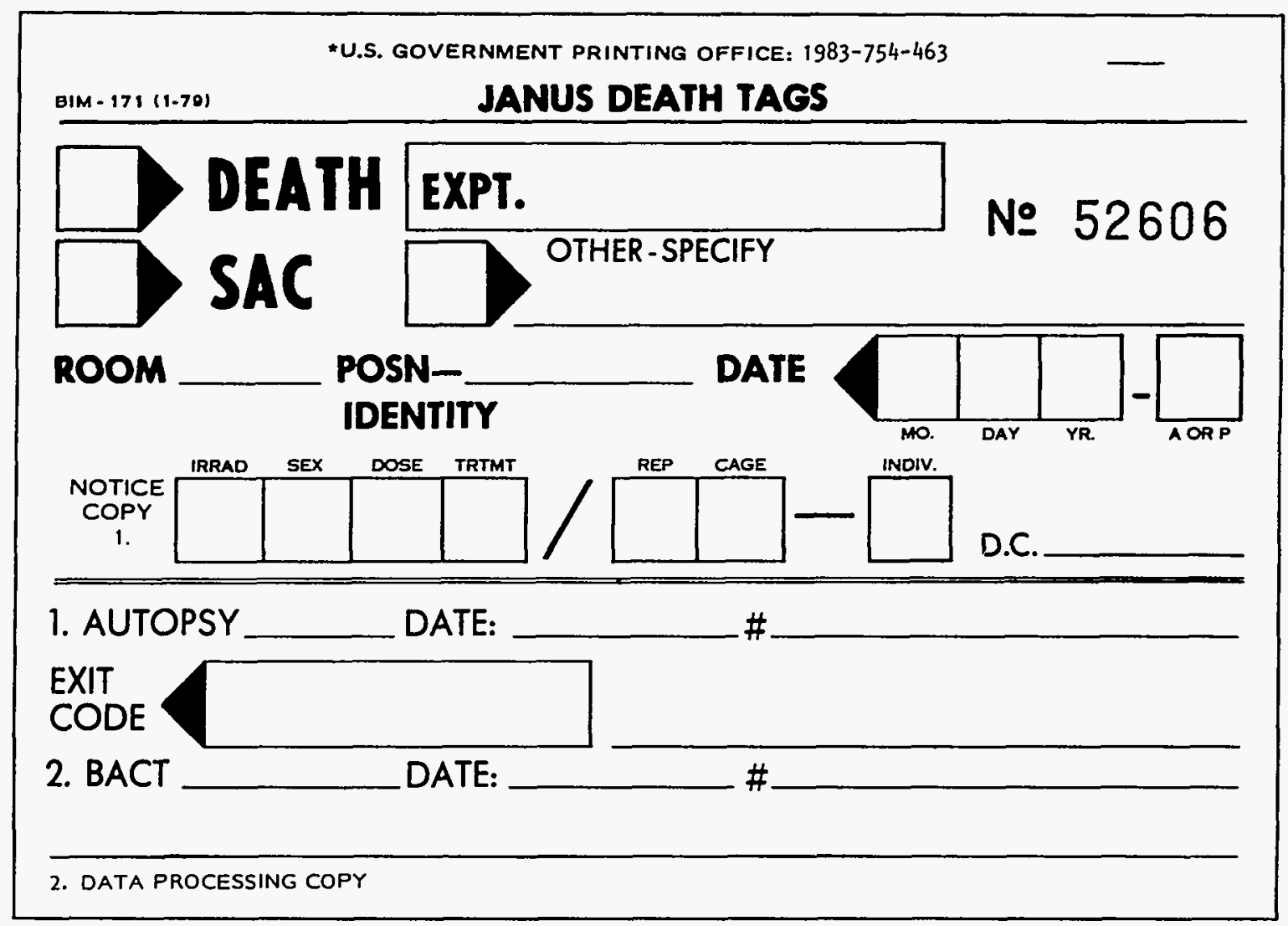

FIGURE A.1 JANUS Death Tag

\begin{tabular}{lll}
\hline EXPT JM-99 & CMPO/04-03 & 5 \\
RM E-129 & & 4 \\
\hline & & 3 \\
\hline
\end{tabular}

FIGURE A.2 Cage Card 
A-4 
B-1

\section{APPENDIX B:}

JANUS EXIT AND AUTOPSY CODES 
B-2 


\section{JANUS EXIT CODES}

\begin{tabular}{|c|c|c|c|}
\hline $\begin{array}{c}\text { In Combined } \\
\text { Pathology } \\
\text { Databases }\end{array}$ & $\begin{array}{c}\text { In ORACLE } \\
\text { Database }\end{array}$ & $\begin{array}{l}\text { Original } \\
\text { Prosector's } \\
\text { Code }\end{array}$ & Definition \\
\hline 0 & & & Not dead yet \\
\hline 1 & 1.0 & 1.1 & Died during fractionation exposure period \\
\hline 1 & 1.0 & 1.2 & Late radiation death \\
\hline 1 & 1.0 & 1.3 & Acute radiation death \\
\hline 2 & 2.0 & 2.1 & Sacrificed, moribund \\
\hline 3 & 3.1 & 3.1 & Escaped during irradiation \\
\hline 3 & 3.2 & 3.2 & Improper irradiation \\
\hline 3 & 3.3 & 3.3 & Accidental death \\
\hline 3 & 3.4 & 3.4 & Unknown, cannibalized \\
\hline 3 & 3.5 & 3.5 & Missing \\
\hline 4 & 4.1 & 4.1 & Programmed sacrifice \\
\hline 5 & 5.1 & 5.1 & Discard \\
\hline 6 & 6.1 & 6.1 & Removed to another experiment \\
\hline 7 & 6.2 & 6.2 & Grahn mice, nonbreeders \\
\hline 8 & 6.3 & 6.3 & Grahn mice, breeders \\
\hline 9 & & & Anything else \\
\hline
\end{tabular}

\section{JANUS AUTOPSY CODES}

$$
\begin{aligned}
& \mathrm{A}=\text { Autopsied } \\
& \mathrm{N}=\text { Not autopsied } \\
& \mathrm{D}=\text { Decomposed }, \text { not autopsied } \\
& \mathrm{C}=\text { Cannibalized, not autopsied }
\end{aligned}
$$




\section{B-4}


C-1

APPENDIX C:

NECROPSY REPORT

a d W 


$$
\text { C-2 }
$$




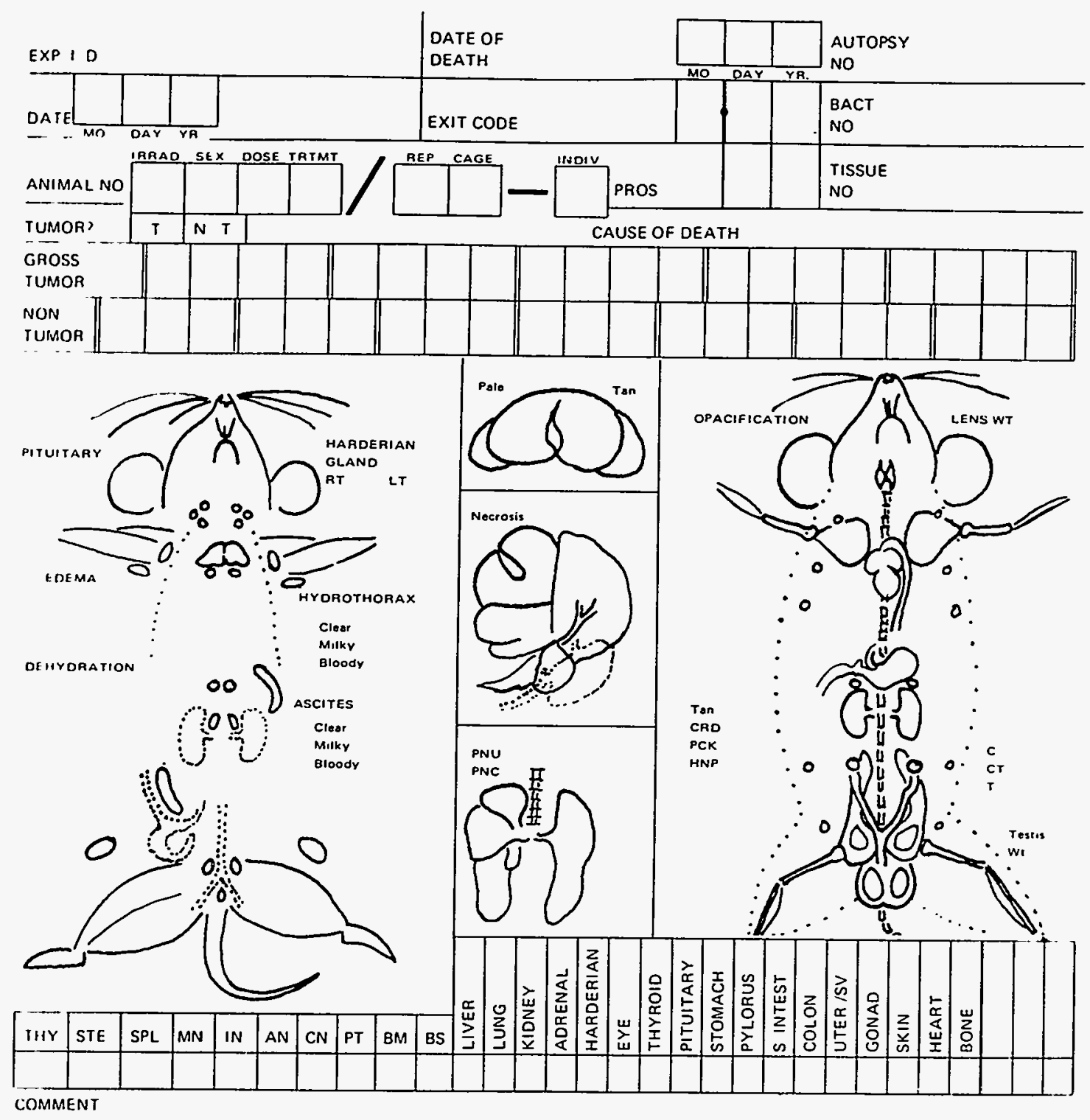

MICRO EXAMINATION

B191 17217721

FIGURE C.1a Necropsy Report, page 1 


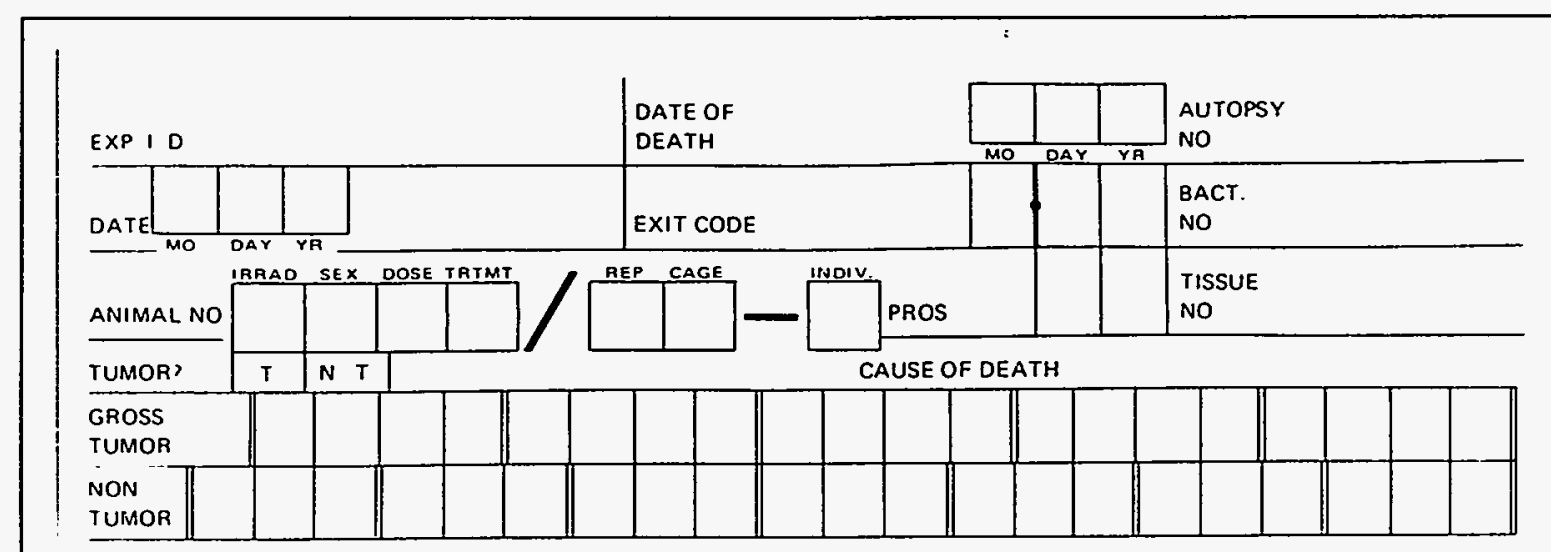

FIGURE C.1b Necropsy Report, page 2 


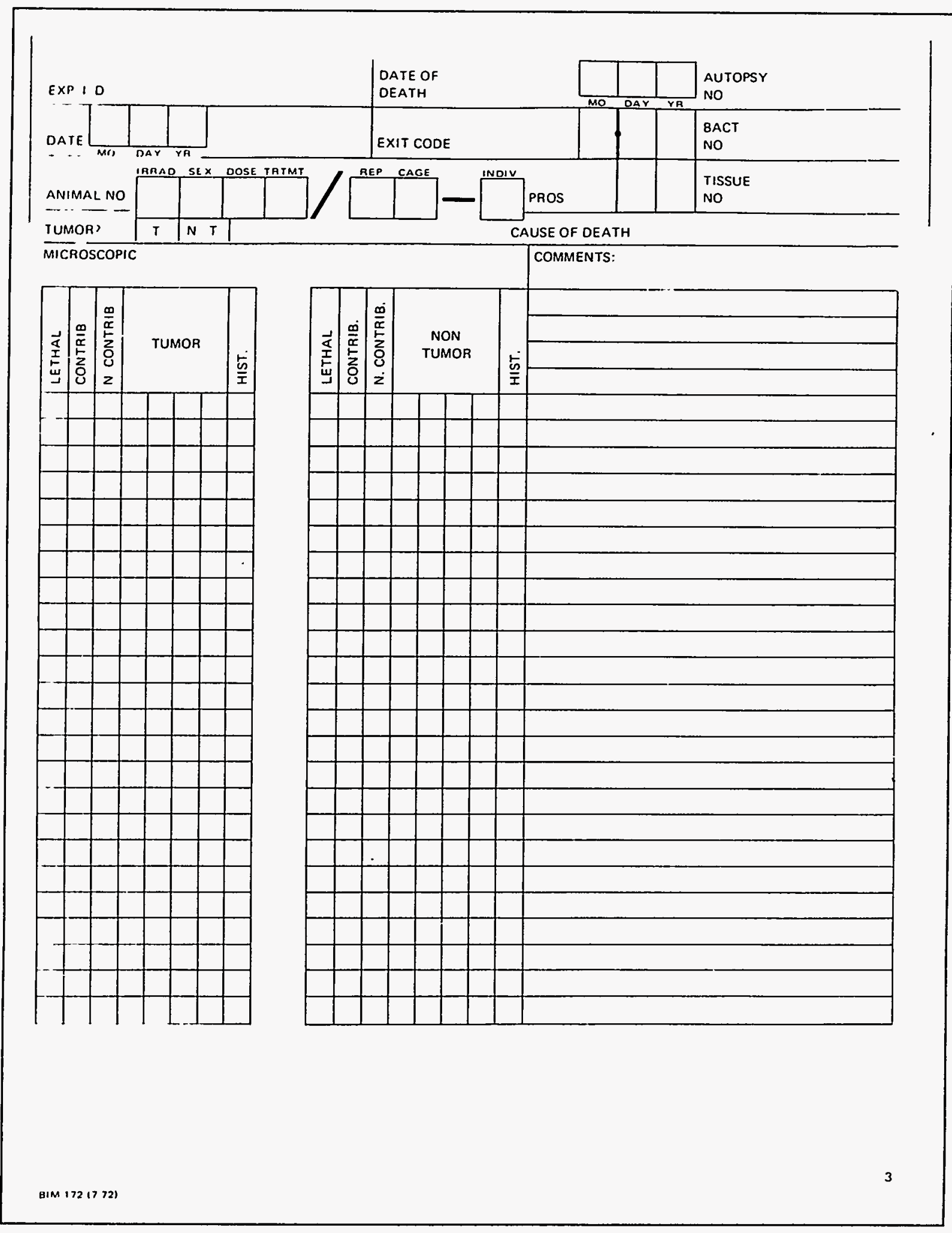

FIGURE C.1c Necropsy Report, page 3 
D-1

APPENDIX D:

PROTOCOL FOR NECROPSY 
D-2 


\title{
APPENDIX D:
}

\section{PROTOCOL FOR NECROPSY}

\section{D.1 EQUIPMENT NEEDED}

\author{
Corkboard \\ Pushpins \\ Iris scissors \\ Hound's-tooth forceps \\ Fine curved forceps, ophthalmologic forceps \\ Cardboard tags \\ Vials of AFA fixative (70\% alcohol, formalin, acetic acid; 20:2:1) \\ Necropsy sheet \\ Killing jar \\ Ether
}

\section{D.2 OVERVIEW}

All animals are checked daily for deaths and for those that are moribund. The moribund animals are sacrificed in the necropsy laboratory in a killing jar with ether. All of the information gathered from an animal is recorded by the prosector on a standardized necropsy report (see Appendix C).

All animals are examined externally to determine if a necropsy can be performed or if the animal has been cannibalized or is autolyzed and a necropsy is not possible. Evidence of trauma, external lesions, or any unusual conditions are also noted at this time. The necropsy is carried out by a systematic examination of the mouse, first ventrally and then dorsally. The subcutaneous structures are examined, followed by an examination of the abdominal cavity. Examination of the abdominal organs aids in the determination of the degree of autolysis; sometimes it is too advanced to fix tissues for histopathology, but a gross examination may determine the probable cause of death. In some cases, autolysis is so advanced that no cause of death can be determined. In any event, the animal is always recorded, and an exit code and autopsy code are assigned.

The usual course of examination proceeds with the removal and examination of the spleen, the pancreas, and then that part of the digestive system including the stomach to the rectum. The reproductive organs and the urogenital system are examined next. The liver is removed for easier examination. The thoracic cavity is then examined, and the heart and lungs are removed for examination. Finally, the head and dorsal aspect are examined. The eyes, Harderian glands, brain, pituitary gland, and vertebral column are checked for lesions and tumors. As the necropsy is carried out, a set of tissues is fixed according to the procedure for collection of tissues for histopathology (Appendices $F$ and $G$ ). The necropsy 
report accompanies the tissues to histological preparation and on to the pathologist who reads the slides and records the histopathological diagnosis.

A more detailed description of the necropsy procedure containing descriptions of normal and disease conditions follows. A description is also presented for each of the codes used in the reporting of the diagnoses of gross observations.

\section{D.3 PROCEDURE}

The dead animal is examined for external lesions (e.g., dermatitis, skin tumors, missing parts) and then pinned to the board ventral side up with a pushpin in each foot. With the scissors and hound's-tooth forceps, a midventral incision is made in the skin from the external genitalia to the angle of the lower jaw. The skin is carefully peeled away exposing the submaxillary salivary glands along with the cervical lymph nodes. Side cuts are made in the inguinal and axillary regions so the skin will lie flat on the board. Examine subcutaneously for edema (graded + to ++++ ), enlarged lymph nodes in the axillary and inguinal regions, active mammary glands, mammary gland tumors, or other lesions that might occur.

\section{SUBCUTANEOUS LESIONS}

\section{Connective Tissue Tumors}

These can appear almost anywhere (subcutaneous, intraperitoneal) and are usually opalescent white and firm on section.

\section{Muscle Tumors}

These usually appear on limb muscles.

\section{Mammary Gland Tumors}

These appear subcutaneously at the mammary gland sites. They are lobular in shape and when cut with a razor blade have a white, moist surface.

\section{Vascular Tumors}

These tumors (hemangiomas and angiosarcomas) can appear in all organs and in connective, muscular, and nervous tissue. 


\section{ABDOMINAL CAVITY}

Open the abdominal cavity with a midventral slit in the peritoneum from the pubis to the diaphragm. Side cuts are made so that the peritoneum will lie flat on the board. If not previously done, the degree of autolysis is determined. Autolysis may be scaled + to ++++ . If no necropsy is performed, the animal is always recorded, and exit and autopsy codes are assigned.

Note ascitic fluid or hemorrhage in the abdominal cavity. Ascitic fluid can be clear, milky, and/or bloody, and the severity is graded on a + to ++++ scale. Attempt to identify the source of the ascitic fluid or hemorrhage.

\section{Spleen}

Remove the spleen and note its size and appearance. The color may be pale, a normal deep red, or a darker red. Note any increase in the white pulp and a reticular or nodular (lumpy) consistency. There may be areas of hemorrhage or vascular tumor. The entire spleen is fixed for all animals.

\section{Pancreas}

The pancreas lies in the mesentery between the stomach and duodenum and is attached to the spleen. A piece may be fortuitously fixed for examination with the spleen because of this attachment. Note the size of the pancreas and any unusual appearance.

\section{Digestive Tract}

Detach the stomach at the esophageal end and from the mesenteries and strip the intestine. Examine for enlarged nodes and diverticula, adhesions, hemorrhage, or infection. Watch for the mesenteric node and leave attached to the colon.

Stomach. Note if the stomach is filled with food or gas or is empty. Split it open to look for tumors in the cardiac, pyloric, or glandular regions or at the pyloric-duodenal junction. Tumors may also be found on the exterior of the stomach.

Intestine. Examine for lesions, inflamed areas, hemorrhages, diverticula, or enlarged nodes. An enlarged mesenteric node can be seen in the mesentery of the colon. If enlarged or abnormal, fix this node with a piece of the colon for identification. 


\section{Urogenital System}

\section{Reproductive System}

Examine the organs individually, paying particular attention to the following:

Ovaries. Note their size and the presence of tumor or cyst. Ovaries may be blood filled or ruptured and may be surrounded with fat or lymphoid tissue.

Uterus. Note if the uterus is distended, fluid-filled, cystic, or contains a tumor.

Testes. Examine and note their size and consistency and the presence of hemorrhagic foci or tumors.

Epididymis and seminal vesicles. Note if distended and fluid-filled. Record color and presence of tumors.

Prostate, Cowper's, and preputial glands. Note size and condition.

\section{Renal System}

Examine the organs individually, paying particular attention to the following.

Urinary bladder. Note if the bladder is full or distended or contains a tumor, and if the urine contains blood or calculi. If the bladder is full and the seminal vesicles are distended, check for a plug in the urethra or a tumor at the neck of the bladder or at the junction of the urethra and the seminal vesicles.

Kidneys. Note size and color of kidneys. Check for multiple cysts, scarred or pitted surfaces. Check for tumors. Hydronephrosis is scaled + to ++++ . One kidney with attached adrenal gland is routinely fixed.

Adrenal Glands. Note their color and size and the presence of cysts and tumors. Fix with kidney.

\section{Liver}

Check its color and size and the presence and location of lesions such as tumors or cysts; note the appearance of the surface as mottled, pitted, or tan areas. Note if the gallbladder is distended. Fix the median lobe containing the gallbladder as well as any tumors. 


\section{Lymph Nodes}

If enlarged, note all and fix at least representative nodes of the periphery (subcutaneous) and in the abdominal cavity.

\section{THORACIC CAVITY}

Open the thorax with a side cut through the ribs, a cut across the diaphragm, and a second cut through the ribs on the other side so that the ribs and sternum can be laid back to expose the heart, lungs, thymus, parathymus, and trachea with thyroid. Fluid in the thorax can be clear, milky, and/or bloody, and the amount is graded a + to ++++ scale; identify source. The heart and lungs are removed for examination.

\section{Lung}

Examine each lobe for tumors, congestion, or consolidation. Pink is normal; dark red or liver-colored indicates pneumonia; an in-between color is indicative of congestion. Tumors should be drawn to scale and placed in the proper location on the lobes. Metastatic tumors frequently develop in the lungs. The entire lung with bronchus is routinely fixed.

\section{Heart}

The heart can be enlarged or small, hard or soft, and pale. Note the presence of tumors or enlarged auricle, which is indicative of a thrombus. The entire heart is routinely fixed.

\section{Lymph Nodes}

The thoracic nodes may be increased in number and enlarged and cause pressure on blood or air flow.

\section{Thymus and Parathymus}

The thymus and parathymus may be enlarged due to lymphoma and are graded + to ++++ . If enlarged, these may be fixed attached to the heart.

\section{Thyroid}

The thyroid straddles the esophagus at the larynx and may be enlarged, cystic, or tumorous. 
Ribs

Examine the ribs for attached lymph nodes and secondary tumors.

\section{HEAD}

Remove the pins and place the mouse on its ventral side. Clip the skin at the nape of the neck and pull skin forward over head to expose skull.

\section{Brain}

Examine the calvarium for abnormalities and then remove it to expose the brain. Examine for hemorrhage and tumors.

\section{Pituitary}

Lift the brain away from the floor of the skull at the olfactory end to expose the pituitary. Examine and carefully scrape aside optic and olfactory nerves. Note any enlargement or discoloration. Fix the pituitary if any abnormalities are noted. If the pituitary adheres to the brain, remove it with the brain and fix them together. If not, fix the pituitary by placing it on a small piece of card and fixing the pituitary attached to the card.

\section{Eyes and Harderian Glands}

Remove the eyes and Harderian glands together. Examine the eyes for opacity. Check the glands for tumors or increased size. Enlarged glands may be either solid tumor or filled with a milky secretion. Fix both eyes and glands if any abnormalities are noted.

\section{SKELETAL SYSTEM}

Examine the long bones for tumors. Strip the skin off the back to expose the dorsal surface of vertebral column and pelvis. If it has been noted that the mouse was paralyzed, check carefully for a spinal tumor.

\section{D.4 CODES FOR GROSS TUMOR DIAGNOSES}

NTYG (non-thymic lymphoma, generalized): Characterized by any or all of the following:

(1) enlarged spleen with increased white pulp areas, may be all white and lumpy;

(2) enlarged liver sometimes with discrete white areas, an overall grainy or rough appearance and texture; (3) enlarged nodes, deep and peripheral; (4) fluid in abdominal cavity and thoracic cavity; fluid may be clear, milky, or bloody; (5) edema; (6) lungs are often severely congested. 
NTYL (non-thymic lymphoma, localized): Only one reticular tissue involved, most commonly the mesenteric node, a lymphoid diverticulum of the gut, or the spleen.

TADN (lung): Nodular, opalescent or white, may be located in any lobe and sometimes more than one in a lobe and in more than one lobe, and size may vary considerably.

TADP (adipose): Enlarged or consolidated area in abdominal fat; more vascularization.

TADR (adrenal): Abnormal size and clear deviation from normal creamy white.

TBLA (bladder): Enlarged bladder is probably distended and urine-filled; abnormality most commonly found at neck of bladder. Urine is usually cloudy, sometimes bloody.

TBON (bone): Visibly enlarged and eroded areas on bones, particularly spine and long bones. No radiographs are taken in this protocol. Bone tumor secondaries may be found in lungs and other organs.

TBRN (brain): May be enlarged area or depressed area, a noticeable change in contour and symmetry, and an increased vascularization.

TCEC (caecum) ${ }^{1}$

TCGL (Cowper's gland): Enlarged Cowper's gland; may "squeeze shut" the urethra.

TCNS (central nervous system): Any enlargement found on/in the spinal cord.

TCOL (colon) ${ }^{1}$

TCON (connective tissue): Hard, opalescent, translucent-to-opaque white mass; can be found almost anywhere (subcutaneous, intraperitoneal); may be large, as this type of tumor is the largest identifiable isolated tumor mass seen. Connective tissue tumor secondaries can be found in lungs, liver, etc. It should be noted that one type of mammary gland tumor may look like a connective tissue tumor.

TDUO (duodenum) ${ }^{1}$

TEPI (epididymis): Enlarged and vascularized.

TESO (esophagus) ${ }^{1}$

TGBL (gallbladder): Thickened and often distended because of a block at the neck.

1 TCEC, TCOL, TDUO, TESO, TILE, TJEJ, TPYL, and TSTO are all codes that refer to tumors of the gastrointestinal tract. Most often these appear as a local thickened area, sometimes with muscle involvement. When the gut is split open longitudinally, the tumor is seen protruding into the lumen. Do not confuse a lymphoid diverticulum with a gastrointestinal tumor. 
THGL (Harderian gland): Creamy white and enlarged, some glands may just be hyperplastic; tumors often push the eye out of the orbit and cover part of the skull. Skull may be domed. Secondaries may be found in lungs.

THIB (hibernating gland): Very rare; the few seen have been hard, discrete nodules in the brown fat between the shoulders.

THRT (heart): Auricles or ventricles may be enlarged; more commonly, discrete inflammatory lesions are seen, but they are easily identified by their texture, color, and overall appearance. There may be a vascular tumor of the heart.

TILE (ileum) ${ }^{1}$

TISO (isograft): Isograft (applies to only JM-11.).

TJEJ (jejunum) ${ }^{1}$

TKID (kidney): May appear to be just a single nodular focus on the surface of the kidney or more diffuse on inside, in which case the kidney may appear larger. Check for secondaries both in the other kidney and from the kidney into other organs; can be differentiated from the usual degenerative diseases.

TLIV (liver): Enlarged lobes, usually "liver-colored"; white areas may be lymphoid. Liver tumors often protrude as large, discrete nodules that sometimes, after long residence, become umbilicated and may involve entire lobes. A large, "bloodier than normal" tumor may be a vascular tumor of the liver; these are not easily distinguished at the gross level and require a histopathological diagnosis.

TMGL (mammary gland): Subcutaneous at mammary gland sites; lobular, white, and moist in appearance. They can extend dorsally, particularly in the anterior region around the back of the neck. One type of mammary gland tumor (MICRO code TMAC) looks more like a connective tissue tumor.

TMIC (miscellaneous connective tissue) ${ }^{2}$

TMID (miscellaneous digestive system) ${ }^{2}$

TMIE (miscellaneous endocrine) ${ }^{2}$

TMIG (miscellaneous glandular) ${ }^{2}$

TMIL (miscellaneous lung): In lung, but not typical TADN appearance. ${ }^{2}$

TMIN (miscellaneous nervous system) ${ }^{2}$

2 All "TM _ (miscellaneous)" codes are used when there is not a typical appearance to the tumor. 
TMIR (miscellaneous reticular system) ${ }^{2}$

TMIS (miscellaneous miscellaneous): Found in uncoded organs or locations. ${ }^{2}$

TMUG (miscellaneous urogenital) ${ }^{2}$

TMUS (muscle): Increased muscle mass, particularly upper forelimb or thigh.

TOVE (ovary): Enlarged; may be cystic at the same time and blood-filled or with ruptured cyst; may be white or yellow. Ovaries may also have vascular tumors but are difficult to distinguish from a bloody cyst or tumor at the gross level; ovaries may also be infiltrated by lymphoid cells.

TPAN (pancreas): Enlarged and sometimes nodular appearance.

TPIT (pituitary): Enlarged, may be bloody. Look particularly for mammary gland or adrenal abnormalities.

TPNS (peripheral nervous system): Enlargement of nerves to limbs, etc. (not spinal cord).

TPPT (preputial gland): Gland may be enlarged and infected (site of acute infection) but may not be a tumor.

TPST (prostate): Enlarged; may obstruct urethra.

TPYL (pylorus) ${ }^{1}$

TSEC (secondary): indicative of secondary tumor in another organ (Harderian gland tumor in lung; kidney tumor in lung; liver tumor in lung).

TSGL (salivary gland): Enlarged salivary gland to be differentiated from enlarged cervical nodes attached to the salivary gland.

TSKN (skin): Eroded areas; raised area especially around the edges of the lesion; sometimes a "weeping" lesion.

TSMV (seminal vesicle): Enlarged, but not to be confused with blockages associated with advanced age.

TSPL (spleen): Enlarged, but to be distinguished from a lymphoid spleen (mostly white pulp) or a vascular tumor of the spleen (bloody).

TSTO (stomach) ${ }^{1}$

TTGE (tongue): Presumably an enlarged tongue. A tumor at this site has not been seen in these studies. 
TTRD (thyroid): Enlarged thyroid; may cause constriction of trachea. Many thyroids are quite large but simply hyperplastic and nontumorous. A microscopic diagnosis is necessary to be sure.

TTST (testis): Enlarged testis (or testes). Testis may also have a vascular tumor.

TTYG (thymic lymphoma, generalized): Enlarged thymus and other lymphoid tissue (see NTYG description).

TTYL (thymic lymphoma, localized): Only the thymus enlarged; no other apparent lymphoid proliferation.

TUTE (uterus): Enlarged uterus; solid mass usually, but sometimes with areas of necrosis. Not to be confused with the overall enlargement associated with lymphoid infiltration or a generalized metritis.

TVAG (vagina): Enlarged vagina because of a mass on the inside.

TVAS (vascular): Vascular tumors can occur in any organ or be located in connective, muscular, or nervous tissue. Common locations are the spleen and liver. Vascular tumors are characterized by a large amount of blood with more or less stroma.

\section{D.5 CODES FOR NONTUMOR DIAGNOSES}

Most of the codes for nontumor diagnoses are indicative of pathological conditions with the usual descriptions for such terms. When the code for an organ (e.g., adrenal [ADR], brain [BRN]) is used, it means that the organ appears abnormal, usually in size, color, etc., but there is no apparent tumor. Most of the nontumor diagnoses are descriptive, and only a few may represent a cause of death. Some of the codes that may be used for a cause of death are

$\begin{array}{ll}\text { ACI } & \text { acute infection } \\ \text { ANE } & \text { anemia } \\ \text { ANU } & \text { aneurysm } \\ \text { CRD } & \text { chronic renal disease } \\ \text { ENT } & \text { enteritis } \\ \text { HRG } & \text { hemorrhage } \\ \text { HNP } & \text { hydronephrosis } \\ \text { MAL } & \text { malocclusion } \\ \text { MET } & \text { metritis } \\ \text { PCK } & \text { polycystic kidney } \\ \text { PER } & \text { peritonitis } \\ \text { PNC } & \text { pneumonitis } \\ \text { PNU } & \text { pneumonia } \\ \text { PRO } & \text { prolapse } \\ \text { THR } & \text { thrombus } \\ \text { TYP } & \text { typhlitis }\end{array}$


These are more indicative of disease states rather than descriptive of conditions. A complete list with definitions of nontumor MACRO codes is found in Appendix E.

\section{D.6 CAUSE OF DEATH}

To establish a probable "cause of death" from the gross findings, there are several criteria that may be applied to the observations. These include

1. Size and extent of the lesion

2. Site of the lesion (some sites/organs may have lesions that are not life threatening even if large)

3. Life-threatening conditions that result from an associated disease (e.g., pneumonia resulting from even a small lung tumor; perforating diverticulitis from NTYG or TTYG; THGL secondaries in the lung)

In addition, there are hints that may be given to the prosector by the overall appearance of the mouse, premortem and postmortem (i.e., difficult breathing, edema, weight loss, lumpy abdomen). 
D-14 


\section{APPENDIX E:}

JANUS MACRO DICTIONARY

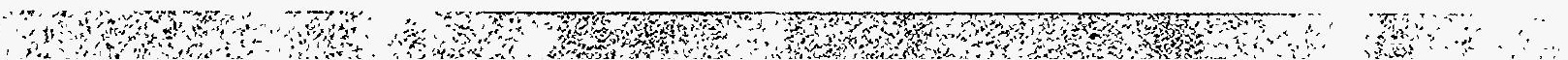


E-2 


\begin{tabular}{|c|c|}
\hline $\begin{array}{l}\text { JANO } \\
\text { Code }\end{array}$ & JANUS Description \\
\hline ABS & ABSCESS \\
\hline ACI & ACUTE INFECTION \\
\hline$A D B$ & ADEESION \\
\hline ADR & ADRENAL \\
\hline AMY & AMYLOID \\
\hline ANE & ANEMIA \\
\hline ANO & ANEURYSM \\
\hline ASC & ASCITES \\
\hline BAC & BACTEREMTA \\
\hline BDY & BLOODY - ETX OR ASC \\
\hline BLA & URINARY BLADDER \\
\hline BON & BONE \\
\hline BRN & BRAIN \\
\hline BSC & BLOODY ASCITES \\
\hline $\mathrm{CAE}$ & $\mathrm{C}(\mathrm{A}) \mathrm{ECUM}$ \\
\hline CAL & CALCIFICATION \\
\hline CAT & CATARACT \\
\hline CDU & CAUSE OF DEATH UNKANOWN \\
\hline CGL & CONPER'S GLAND \\
\hline $\mathrm{CHO}$ & CHOLECYSTITIS \\
\hline CIR & CIRRHOSIS \\
\hline CII & CALCULI (URINARY BLADDER) \\
\hline CIR & CLEAR HTX OR ASC \\
\hline CNS & CENIRAL NERVOUS SYSTEM \\
\hline COL & COLON \\
\hline CRD & CERONIC RENAI DISEASE \\
\hline CYS & CYST \\
\hline DER & DERMATITIS \\
\hline DHY & DEHYDRATION \\
\hline DIV & DIVERTICOLOM (GI) \\
\hline DUO & DUODENUM \\
\hline EDA & EDEMA \\
\hline EMB & EMBOLUS \\
\hline EMP & EMPEYSEMA \\
\hline ENT & ENTERITIS \\
\hline EPL & EPILATION \\
\hline Eso & ESOPHAGUS \\
\hline FIT & EIGETING \\
\hline GBL & GALI BLADDER \\
\hline GEN & EXIERNAL GENITALIA \\
\hline GON & GONAD \\
\hline GRY & GRAYNRSS \\
\hline
\end{tabular}

S N Topography Morphology SNOMBD Description

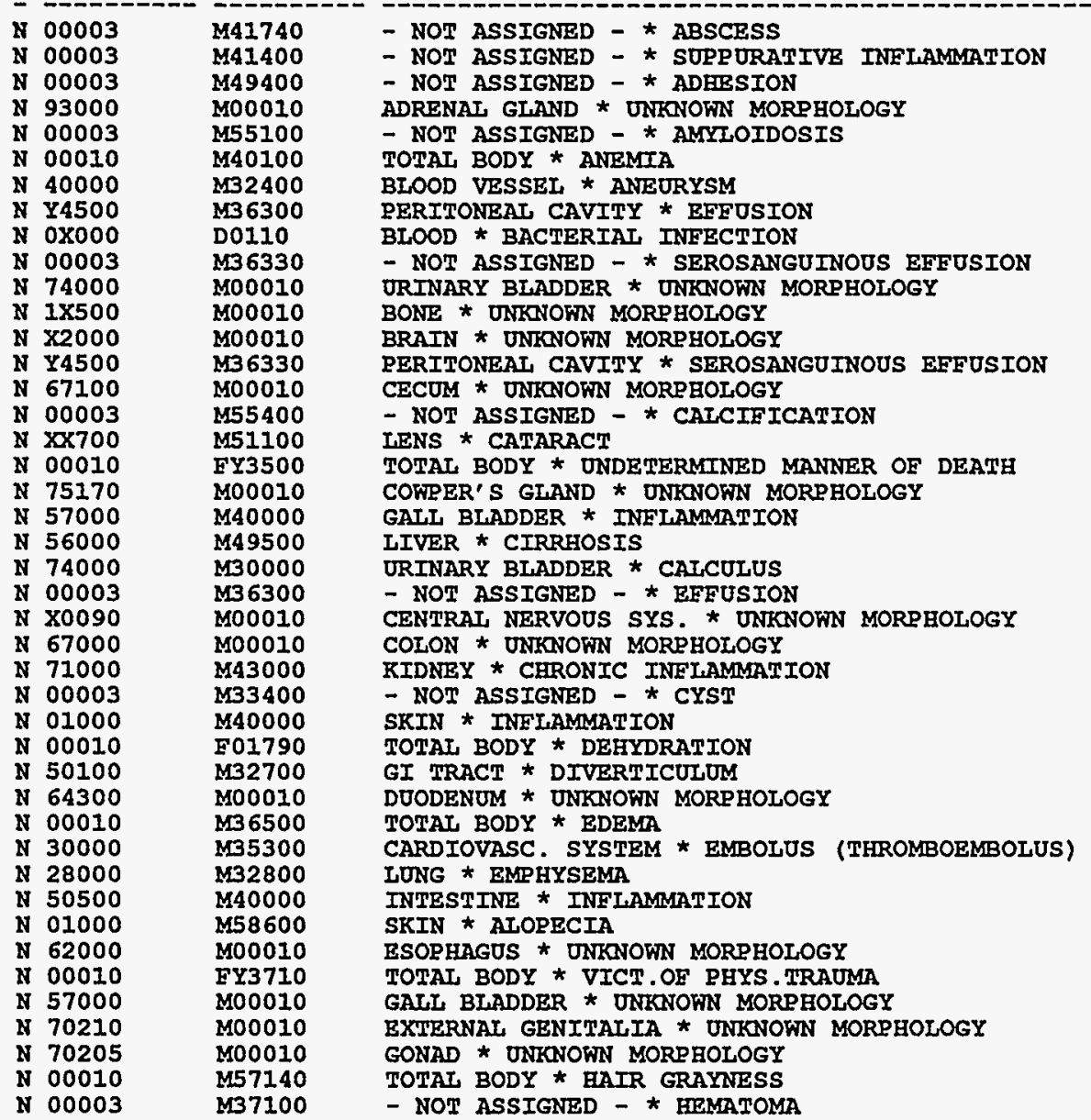


JANOS MACRO DICTIONARY - SNOMED/SNOVET CONVERT Ordered bY MOUSCODE July 11,1994 bjK

\begin{tabular}{|c|c|c|c|c|}
\hline $\begin{array}{l}\text { JANUS } \\
\text { Code }\end{array}$ & JANOS Description & $\begin{array}{l}\text { P } \\
\text { S } \\
\text { N Topography }\end{array}$ & Morphology & SNOMED Description \\
\hline HEP & HEPATITIS & N 56000 & M41000 & LIVER * ACOTE INELAMMATION \\
\hline HGL & EARDERIAN GLAND & N $x \times 836$ & M00010 & HARDERIAN GILAND * UNKNOWN MORPHOLOGY \\
\hline ENP & HYDRONEPHROSIS & N 72000 & MB3300 & PELVIS OF KIDNEY * FLUID RETENTION \\
\hline HRG & HEMORRHAAGE & N 00003 & M37000 & - NOT ASSIGNED - * HEMORRHAGE \\
\hline HRT & GEART & N 32000 & M00010 & GEART * UNRNOWN MORPHOLOGY \\
\hline BTX & EYDROTHORAX & N Y2200 & M33300 & THORACIC CAVITY * FLOID RETENTION \\
\hline IIE & ILEUM & N 65200 & M00010 & ILEUM * UNKNOWN MORPHOLOGY \\
\hline $\mathbf{I N E}$ & INF LAMMATION & N 00003 & M40000 & - NOT ASSIGNED - * INFIAMMATION \\
\hline INT & INTUSSUSCEPTION & N50500 & M31130 & INTESTINE * INTUSSUSCEPTION \\
\hline Iso & ISOGRAFT & $\mathrm{N} 00003$ & M15600 & - NOT ASSIGNED - * TRANSPLANTED TISSUE \\
\hline JAU & JAUNDICE & N 00010 & M57600 & TOTAL BODY * JAUNDICE \\
\hline JEJ & JEJONOM & N 65100 & M00010 & JEJUNUM * ONRNOWN MORPBOLOGY \\
\hline KID & KIDNEY & N 71000 & M00010 & KIDNEY * UNRAYWN MORPEOLOGY \\
\hline IIV & LIVER & N 56000 & M00010 & LIIVER * UNKKNOWN MORPHOLOGY \\
\hline LOB & LOBAR PNEOMONIA & N 28000 & M40000 & LUNG * INTLAMMATION \\
\hline MAL & MALOCCLUSION & N 54010 & F60430 & TOOTH * MALOCCLUSION \\
\hline MET & METRITIS & N 82000 & M40000 & UTEROS * TNELAMMATION \\
\hline MGC & MEGACOLON & $\mathrm{N} 67000$ & M32220 & COLON * HYPERDISTENTION \\
\hline MGL & MAMMARY GLARND & N 04000 & M00010 & MAMMARY GLAND * UNKNOWN MORPHOLOGY \\
\hline MIC & MISC - CIRCULATORY & N 30000 & M00010 & CARDIOVASC. SYSTEM * UNKNOWN MORPHOLOGY \\
\hline MID & MISC - DIGESTIVE & N 50000 & M00010 & DIGESTIVE SYSTEM * UNKNOWN MORPHOLOGY \\
\hline MIG & MISC - URO-GENITAL & N 70000 & M00010 & GENITO-URINARY SYST. * ONKNOWN MORPHOLOGY \\
\hline MII & MISC - LONG & N 28000 & M00010 & LUNG * UNKNOWN MORPHOLOGY \\
\hline MLR & MISC - RENAL (URINARY TRACT) & $\mathrm{N} 70100$ & M00010 & URINARY TRACT * UNKWNOWN MORPHOLOGY \\
\hline MIS & OTHERS - GENERAL & N 00003 & M00010 & - NOT ASSIGNED - * UNRNOWN MORPHOLOGY \\
\hline MKY & MIIKY & N 00003 & M36340 & - NOT ASSIGNED - * CHYLOUS EFEUSION (MILKY) \\
\hline MSC & MILKY ASCIMES & N Y 4500 & M36340 & PERITONEAL CAVITY * CHYLOUS EFEUSION (MILKY) \\
\hline MYO & MYOCARDIUM & N 33010 & M00010 & MYOCARDIUM * UNKNOWN MORPHOLOGY \\
\hline NEC & NECROSIS & $\mathrm{N} 00003$ & M54000 & - NOT ASSIGNED - * NECROSIS \\
\hline $\mathrm{OBE}$ & OBESE & N 00010 & M71800 & TOTAL BODY * OBESITY \\
\hline OBS & OBSTROCTION & N 00003 & $M 34000$ & - NOT ASSIGNED - * OBSTRUCTION \\
\hline OVE & OVARY & N 87000 & M00010 & OVARY * UNKNYOWN MORPBOLOGY \\
\hline PAN & PANCREATITIS & N 59000 & M40000 & PANCREAS * INFLAMMATION \\
\hline PAR & PARALYSIS & N 00003 & F80840 & - NOT ASSIGNED - * PARAIIYSIS \\
\hline $\mathrm{PCD}$ & RERICARDIUM & N 31000 & M00010 & PERICARDIUM * UNKNOWN MORPEOLOGY \\
\hline PCK & POLYCYSTIC KIDNEY & N 71000 & M26730 & KIDNEY * POLYCYSTIC KIDNEY DISEASE, ADULT TYPE \\
\hline PEN & PENIS & N 76000 & M00010 & PENIS * UNKNOWN MORPHOLOGY \\
\hline RER & PERITONITIS & N Y4400 & $\mathbf{M} 40000$ & PERITONEUM * INEIAMMATION \\
\hline PGI & PREPUTIAL GLAND & N 76350 & M00010 & RREPUTIAL GLAND * UNKRNOWN MORPHOLOGY \\
\hline PIT & PITUITARY & N 91000 & M00010 & PITOITARY * UNKONOWN MORPBOLOGY \\
\hline PNC & PNEUMONITIS & N 28000 & M36100 & LUNG * CONGESTION \\
\hline PNO & PNEUMONIA & N 28000 & M40000 & LONG * INFLAMMATION \\
\hline PRF & PERFORATION & N 00003 & M39800 & - NOT ASSIGNED - * PERFORATION \\
\hline
\end{tabular}


JANOS MACRO DICTIONARY - SNOMED/SNOVET CONVERT OIdered bY MOOSCODE July 11, 1994 bjw

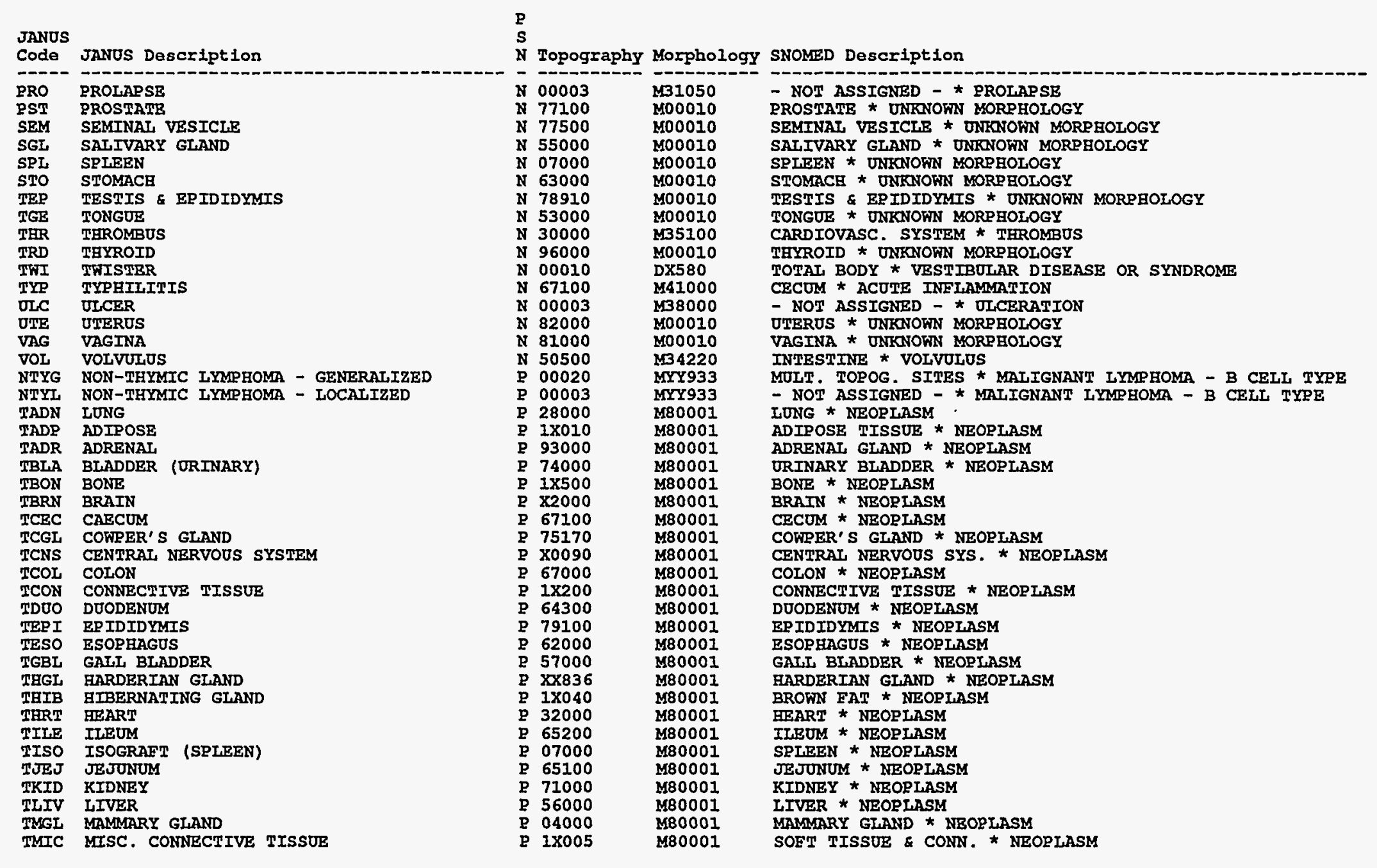




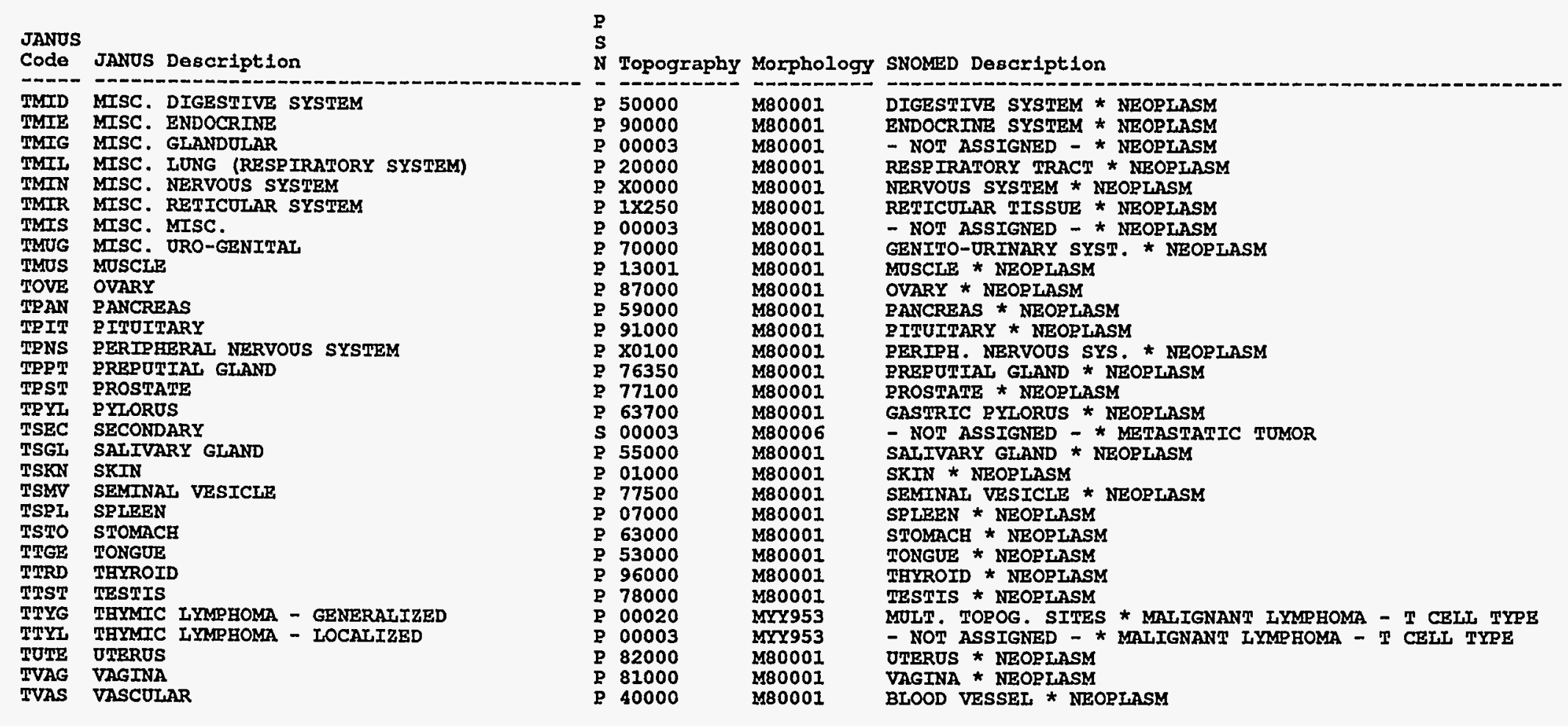

159 rows selected. 


\section{APPENDIX F:}

PROCEDURE FOR COLLECTION OF TISSUES FOR HISTOPATHOLOGY 


$$
\text { F-2 }
$$




\section{APPENDIX F: \\ PROCEDURE FOR COLLECTION OF TISSUES FOR HISTOPATHOLOGY}

1. Necropsies are to be performed as outlined in Appendix D.

a. When a mouse is partially cannibalized, the remaining tissues should be taken as defined below.

b. When autolysis is borderline, tissues should be taken.

2. The following tissues are to be collected for histopathologic processing.

a. Lung: The entire lung should be taken with bronchus for fixation. If this is not possible, tumor(s) or lesions that appear grossly different from each other should be taken with adjacent uninvolved.lung. When a primary typical lung tumor is the apparent cause of death and no other tumor(s) or gross lesions are found, no tissue should be saved from the mouse.

b. Liver: If no tumors or lesions are present, the median lobe with the gallbladder should be taken. Tumor(s) or gross lesions are to be collected with a sample of adjacent uninvolved liver.

c. Spleen: The entire spleen should be taken if possible. If not, tumor(s) that appear grossly different are to be taken with adjacent uninvolved spleen.

d. Kidney: One kidney with attached adrenal gland is to be taken routinely when no lesions are grossly apparent. When one kidney is abnormal, except in the case of hydronephrosis, then both should be taken. Tumor(s) or lesions that appear grossly different are to be collected with adjacent normal tissue.

e. Heart: The entire heart is to be fixed separated from the lungs.

f. When the diagnosis is a generalized or localized lymphoma, the cervical nodes should be taken with the salivary gland, the pararenal node should be taken with the kidney, the parathymic nodes and thymus with the heart, and the mesenteric node with a piece of gut. Only one peripheral node need be collected. Other nodes should be taken only when involved with a different tumor or lesion. If the mouse is partially autolyzed, the freshest node is to be taken.

3. In addition to the above standard organs, other tissues are to be collected when any gross lesions (i.e., tumors, degenerative or inflammatory processes) are present. The 
following organs and organ systems are examples of such other tissues and are to be examined and sampled:

- Mammary gland

- Harderian gland with eye

- Gut

- Ovaries or testes

- Brain and pituitary

- Any tissue or organ suspected of having a vascular tumor

- Bone

While other tissues that appear normal may have relevance in the cause of death, the practical problem of completing the tissue processing makes it imperative to limit the numbers of specimens collected. For example, without a terminal radiograph, the incidence of bone tumors cannot be determined; therefore, the number of bone tumors observed during necropsy is not conclusive. Other rare sites for tumors and lesions should not be collected unless, in the opinion of the prosector, the additional tissues will define the cause or contributing factors of death and not just add incidental or coincidental data on tumors. 
G-1

APPENDIX G:

HISTOLOGY PROCEDURE 
G-2 


\section{APPENDIX G: \\ HISTOLOGY PROCEDURE}

1. Tissues are fixed in $70 \%$ AFA (20 parts $70 \%$ ethanol, 2 parts neutral formaldehyde [37-40\%], 1 part glacial acetic acid).

2. The tissues are processed in the following manner.

The tissue is trimmed to a 2- to $5-\mathrm{mm}$ thickness to present a face to be studied. The trimming is done by using the necropsy report as a guide. The trimmed tissues are grouped into tissue cassettes according to how they will be blocked for cutting. The cassettes are kept in 70\% ethanol until processed. Processing is done in an Autotechnicon by dehydration through a series of increasing grades of ethanol and cleared in isoamyl acetate. After clearing, the tissues are put through several changes of paraffin-embedding medium (melting point, $56-58^{\circ} \mathrm{C}$ ).

The tissues are completely infiltrated with fresh paraffin in a vacuum oven. The tissues are embedded in paraffin in the arrangement for the slide. (See the slide chart, Fig. G.1, for one possible positioning. Any additional tissues are mounted on other slides.)

3. Sections are to be cut to a thickness of 4-5 $\mu \mathrm{m}$, mounted on slides, and dried.

4. An automatic stainer (Gam Rad) is used to stain with hematoxylin-eosin.

5. The stained slides are coverslipped, dried, boxed, and sent with the necropsy sheets to the pathologist.

6. When the diagnosis is completed, the slides are returned for filing, and the necropsy report is returned for MICRO data entry. 

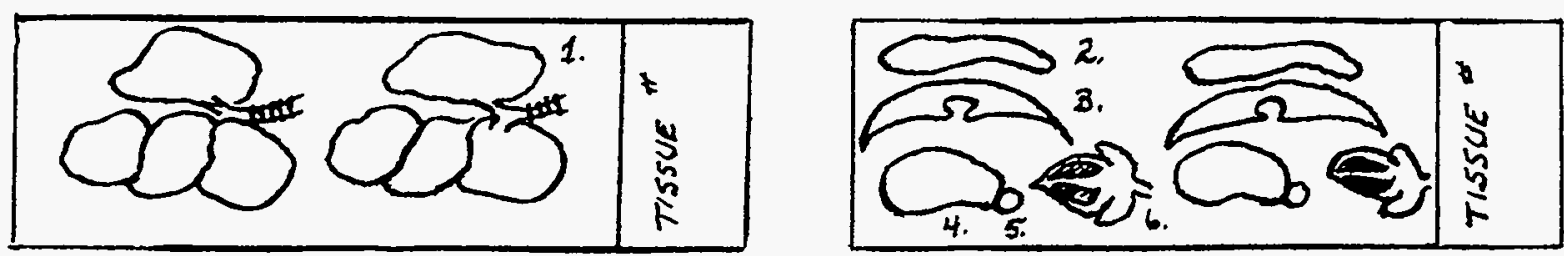

Legend: 1) lung, 2) spleen, 3) liver, 4) kidney, 5) adrenal gland, 6) heart

FIGURE G.1 Slide Chart of Standard Tissues Taken 
APPENDIX H:

\section{JANUS MICRO DICTIONARY}


H-2 


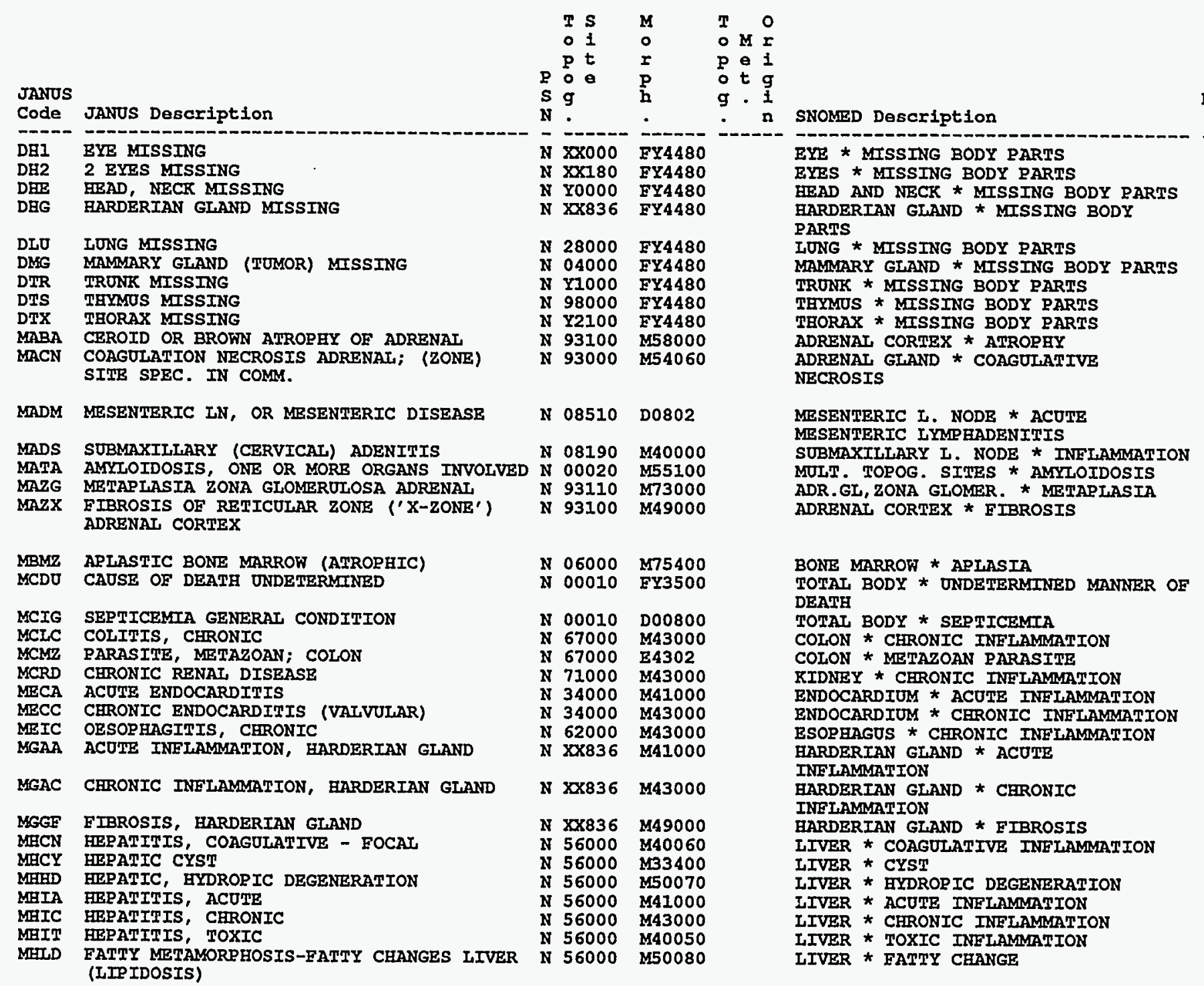

etastatic

Origin 


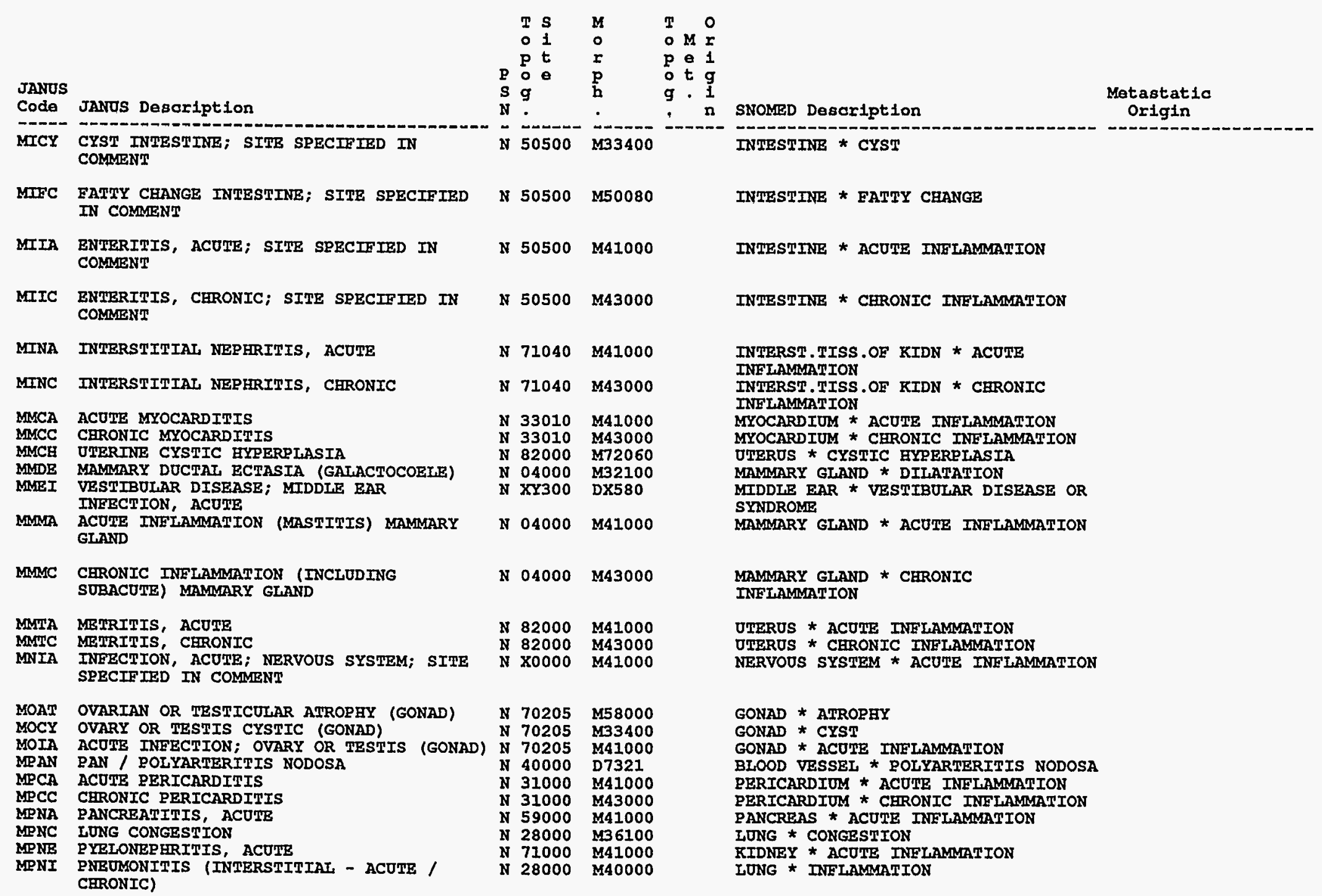


JaNUS JANUS Description

MPNP PYONEPERITIS (PYELONEPHRITIS)

MPNO PNEUNONIA, ACOTE AND SUBACOTE

MPRA PROSTATITIS, ACUTE

MPRA RROSTATIC HYPERPLASIA

IMRS STASIS PROSTATE

MPIH HYPERPLASIA OF PARATHYROID GLAND (EYPRRTROPEY)

\section{MRMP MURINE PNEUMONIA}

MROD RENAL OSTEODYSTRORHY

RLEURITIS, IOCAI OR GENERALIZED

MSAC SIALADENITIS, CERONIC

MSCN COAGULATION NECROSIS SPLEEN

MSDA DERMATITIS, ACUIE

MSGF FIBROSIS SALIVARY GLAND

MSTC ICANT

MSLC LIMPEOID GXPRRPLASIA SPLEE

(ATROPHIC)

USTA THYROIDITIS, ACUTB

USVA HEMTNAT VESTCTE, ACDNR INTETMMATION

MSVE SEMINAL VESTCLE HYEERPLASIA

MSVS STASIS SEMTNAL VESICLE

MUCA CYSTITIS, ACUTE

MUCC CYSTITIS, CHRONIC

MURA URETERITIS, ACUTE

MURC URETERITIS, CERONIC

MORH URETERAI EPITEEITAL HYPERPIAASTA

MXWI PERITONITIS, LOCAL OR GENERALIZED

TACC CORTICAI CARCINOMA ADRENAI

TACO CORTICAL ADENOMA ADRENAI CORTRX

TANS MRDULTARY NEUROBLASTOMA (GANGLIONEUROMA) ADRENAI

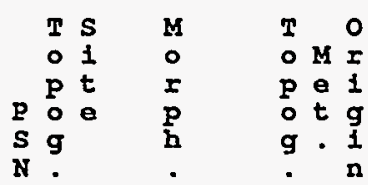

N $71000 \quad \mathrm{M} 41400$

N $20000 \quad M 41000$

N $77100 \quad \$ 41000$

N $77100 \quad \mathrm{M72000}$

N 77100 M33000

(197800

N $20000 \quad D 03442$

N $1 \times 500 \quad D 6561$

N $29000 \quad M 40000$

N 55000 M41000

N $55000 \quad M 43000$

N $07000 \quad M 54060$

N $01000 \quad M 41000$

$N 01000$ M43000

N $55000 \quad M 49000$

N 01000 M72710

N 07000 M72200

N 07000 M75400

N 96000 M

N 77500 M

N $77500 \quad M 72000$

N $77500 \quad M 33000$

N $32000 \quad M 35100$

N $74000 \quad M 41000$

N $74000 \quad M 43000$

N $73000 \quad \mathrm{M} 41000$

N $73000 \quad \mathrm{M} 43000$

73000 M72000

Y3100 180103

$93100 \mathrm{M} 81400$

M95003

0

a $\frac{1}{2}$
Metastatic

SNOMED Description

Origin

KIDNEY * SUPPURATIVE TNETAMMATION

RESP IRATORY TRACT * ACUTE

INELAMMATION

PROSTATE * ACUTE INELAMMATION

PROSTATE * EYPERPLASIA

PARATHYROID GLAND * EYPERPLASIA

RESP TRATORY TRACT * MURTNE

PNEUMONIA

BONE * RENAL OSTEODYSTROPHY

PLBURA * INFLAMMATION

SALIVARY GLAND * ACUTE INTLAMMATIO

SALIVARY GLAND * CERONIC

INELAMMAION

SPLEEN * COAGULATIVE NECROSIS

SKIN * ACUIE INFLAMMATION

SAI * CARONIC IN LLMMATIO

SALIVARY GLAND * FIBROSIS

SRIN * ACANIBOSIS

SPLEEN * APLASIA

INFTAMMATION

SEMTID * LYTERTASIA

ACUTE

INELAMATIOH

* EYPERPLASIA

SEMINAI VESICLR * STASIS

UEARI * TEROMBUS

* ACUTE

INR LAMY

URINARY BLLADDER * CHRONIC

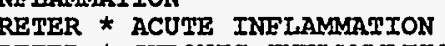

URETER * CERONIC INFLAMMATION

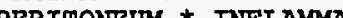

DRRIOI COR * IN LAMMTION

ARR CORIEX * CARCINOMA

ADRENAL MEDULIAA * NEUROBLASTOMA 


\begin{tabular}{|c|c|c|c|c|c|c|c|}
\hline $\begin{array}{l}\text { Janus } \\
\text { Code }\end{array}$ & JANUS Description & 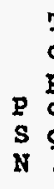 & $\begin{array}{ll}T & 5 \\
0 & 1 \\
\text { p } & t \\
0 & e \\
g & \end{array}$ & $\begin{array}{l}M \\
0 \\
\mathbf{r} \\
\mathbf{p} \\
\mathfrak{b} \\
.\end{array}$ & $\begin{array}{lll}T & & 0 \\
0 & M & I \\
p & e & 1 \\
0 & t & g \\
g & \cdot & i \\
. & & n\end{array}$ & SNOMED Description & $\begin{array}{l}\text { Metastatic } \\
\text { Origin }\end{array}$ \\
\hline $\begin{array}{l}\text { TAPS } \\
\text { TAUOO } \\
\text { TAVO } \\
\text { TAFI }\end{array}$ & $\begin{array}{l}\text { MEDULTLARY PEEOCEROMOCYTOMA ADRENAL } \\
\text { TUMOR (UNDETERMINED CELI TYPE) ADRENAL } \\
\text { VASCUI.AR TUMOR ADRENAL (HEMANGIOMA) } \\
\text { GI TRACT ORIGIN IN COMMENT; MET. TO } \\
\text { ADRENAI }\end{array}$ & $\begin{array}{l}P \\
P \\
P \\
S\end{array}$ & $\begin{array}{l}93200 \\
93000 \\
93000 \\
93000\end{array}$ & $\begin{array}{l}M 87000 \\
M 80001 \\
M 91200\end{array}$ & 50100 & $\begin{array}{l}\text { ADRENAI MEDULIA * PHEOCBROMOCYTOMA } \\
\text { ADRBNAI GLAND * MEOPLLASM } \\
\text { ADRENAI GLAND * MEMANGIOMA } \\
\text { ADRENAL GLAND * }\end{array}$ & GI TRACT \\
\hline $\begin{array}{l}\text { TAWK } \\
\text { TAWM }\end{array}$ & $\begin{array}{l}\text { KIDNEY ORIGIN; MET. TO ADRENAU } \\
\text { MOSCIN ORIGIN IN COMMENT; MET. TO } \\
\text { ADRENAL }\end{array}$ & $\begin{array}{l}\mathbf{s} \\
\mathbf{s}\end{array}$ & $\begin{array}{l}93000 \\
93000\end{array}$ & & $\begin{array}{l}71000 \\
13001\end{array}$ & $\begin{array}{l}\text { ADRENAL GLAND * } \\
\text { ADRENAL GLAND * }\end{array}$ & $\begin{array}{l}\text { KIDNEY } \\
\text { MOSCIE }\end{array}$ \\
\hline $\begin{array}{l}\text { TAFO } \\
\text { TAHR }\end{array}$ & $\begin{array}{l}\text { OVARY ORIGIN; MET. TO ADRENAL } \\
\text { RESPIRATORY SYSTEM ORIGIN; MET. TO } \\
\text { ADRENAL }\end{array}$ & $\begin{array}{l}\mathbf{s} \\
\mathbf{s}\end{array}$ & $\begin{array}{l}93000 \\
93000\end{array}$ & & $\begin{array}{l}87000 \\
20000\end{array}$ & $\begin{array}{l}\text { ADRENAL GLAND * } \\
\text { ADRENAL GLAND * }\end{array}$ & $\begin{array}{l}\text { OVARY } \\
\text { RESPIRATORY TRACT }\end{array}$ \\
\hline $\begin{array}{l}\text { TAWS } \\
\text { TAWU } \\
\text { TAWZ } \\
\text { TACS }\end{array}$ & $\begin{array}{l}\text { SKIN ORIGIN IN COMMENT; MET. TO ADRENAL } \\
\text { OTEROS ORIGIN; MET. TO ADRENAI } \\
\text { THYROID ORIGIN; MET. TO ADRENAL } \\
\text { CEONDROSARCOMA BONE SITE SPECIFIED IN } \\
\text { COMMENT }\end{array}$ & $\begin{array}{l}\mathbf{S} \\
\mathbf{S} \\
\mathbf{S} \\
\mathbf{P}\end{array}$ & $\begin{array}{l}93000 \\
93000 \\
93000 \\
1 \times 500\end{array}$ & M92203 & $\begin{array}{l}01000 \\
82000 \\
96000\end{array}$ & $\begin{array}{l}\text { ADRENAI GLAND * } \\
\text { ADRENAI GLAND * } \\
\text { ADRENAI GLAND * } \\
\text { BONE * CHONDROSARCOMA }\end{array}$ & $\begin{array}{l}\text { SKIN } \\
\text { UTERUS } \\
\text { THYROID }\end{array}$ \\
\hline TBFS & $\begin{array}{l}\text { FIBROSARCOMA BONE SITE SPECIFIED IN } \\
\text { COMMENT }\end{array}$ & $\mathbf{p}$ & $1 \times 500$ & M88103 & & BONE * FIBROSARCOMA & \\
\hline $\begin{array}{l}\text { TBOO } \\
\text { TBOS }\end{array}$ & $\begin{array}{l}\text { OSTEOMA BONE SITE SPEC. IN COMMENT } \\
\text { OSTEOSARCOMA BONE SITE SPECIFIED IN } \\
\text { COMMENT }\end{array}$ & $\stackrel{p}{P}$ & $\begin{array}{l}1 \times 500 \\
1 \times 500\end{array}$ & $\begin{array}{l}\text { M91800 } \\
\text { M91803 }\end{array}$ & & $\begin{array}{l}\text { BONE * OSTEOMA } \\
\text { BONE * OSTEOSARCOMA }\end{array}$ & \\
\hline TBUS & $\begin{array}{l}\text { ODONTOGENIC SARCOMA BONE SITE SPECIFIED } \\
\text { IN COMMENT }\end{array}$ & $\mathbf{P}$ & $1 \times 500$ & M92703 & & BONE * ODONTOGENIC SARCOMA & \\
\hline TBVO & $\begin{array}{l}\text { STERNAL MARROW VASCULAR TUMOR } \\
\text { (BRMANGIOMA) }\end{array}$ & $\mathbf{P}$ & 06000 & M91200 & & BONB MARROW * HEMANGIOMA & \\
\hline TBVS & $\begin{array}{l}\text { VASCULAR TUMOR (ANGIOSARCOMA) BONE SITE } \\
\text { SREC. IN COMMENI }\end{array}$ & $\mathbf{p}$ & $2 \times 500$ & M91203 & & BONE * ANGIOSARCOMA & \\
\hline TBWG & $\begin{array}{l}\text { BARDERIAN GLAND ORIGIN; BONE MRT. SITE } \\
\text { SPEC. IN COMMENT }\end{array}$ & $\mathbf{s}$ & $1 \times 500$ & & $x x 836$ & BONE * & GARDERIAN GLAND \\
\hline TBFM & $\begin{array}{l}\text { MUSCLE ORIGIN IN COMMENT; BONE MET. SITE } \\
\text { SPEC. IN COMMENT }\end{array}$ & $\mathbf{s}$ & $1 \times 500$ & & 13001 & BONB * & MOSCIE \\
\hline TBFN & $\begin{array}{l}\text { NERVOUS SYSTEM ORIGIN IN COMMENT;BONE } \\
\text { MET. SITE SPEC. IN COT }\end{array}$ & $\mathbf{s}$ & $1 \times 500$ & & $\mathbf{x} 0000$ & BONE * & NERVOOS SYSTEM \\
\hline
\end{tabular}




\begin{tabular}{|c|c|c|c|c|c|c|c|}
\hline $\begin{array}{l}\text { JANOS } \\
\text { Code }\end{array}$ & JANOS Description & $\begin{array}{l}P \\
S \\
N\end{array}$ & $\begin{array}{ll}T & s \\
0 & i \\
p & t \\
0 & e \\
g & \\
0 & \end{array}$ & $\begin{array}{l}M \\
0 \\
\mathbf{r} \\
\mathbf{p} \\
\mathbf{h} \\
\dot{ }\end{array}$ & $\begin{array}{lll}T & & 0 \\
0 & M & x \\
\mathrm{P} & \mathrm{e} & 1 \\
0 & \mathrm{t} & \mathrm{g} \\
\mathrm{g} & \cdot & 1 \\
0 & & \mathrm{I}\end{array}$ & SNOMED Description & $\begin{array}{l}\text { Metastatic } \\
\text { Origin }\end{array}$ \\
\hline TBER & $\begin{array}{l}\text { RRSPIRATORY SYSTEM ORIGIN; BONE MET. } \\
\text { SITE SPEC. IN COMMENT }\end{array}$ & $\mathbf{s}$ & $1 \times 500$ & & 20000 & BONE * & RESPIRATORY TRACT \\
\hline TBWS & $\begin{array}{l}\text { SRIN ORIGIN IN COMMENT; BONE MET. SITE } \\
\text { SPEC. IN COMMENT }\end{array}$ & $\mathbf{s}$ & $1 \times 500$ & & 01000 & BONE * & SKIN \\
\hline TBFX & $\begin{array}{l}\text { TISSUE OF ORIGIN IN COMMENT; BONE MET. } \\
\text { SITE SPEC. IN COMM. }\end{array}$ & $\mathbf{s}$ & $1 \times 500$ & & 00003 & BONE * & - NOT ASSIGNBD - \\
\hline TCFO & $\begin{array}{l}\text { FIBROMA CONN. TISS. SIIE SPEC, IN } \\
\text { COMMENT }\end{array}$ & $\mathbf{P}$ & $1 \times 200$ & M88100 & & CONNECTIVE TISSUE * FIBROMA & \\
\hline TCFS & $\begin{array}{l}\text { FIBROSARCOMA CONN. TISS. SITE SPECIFIED } \\
\text { IN COMMENT }\end{array}$ & $\mathbf{P}$ & $1 \times 200$ & M88103 & & CONNECTIVE TISSUE * FIBROSARCOMA & \\
\hline TCMS & $\begin{array}{l}\text { MAST CELL TOMOR CONNECTIVE TISSUE SITE } \\
\text { SPECIFIED IN COMMENT }\end{array}$ & $\mathbf{P}$ & $1 \times 200$ & M97401 & & CONIECTIVE TISSUE * MASTOCYTOMA & \\
\hline TCOO & $\begin{array}{l}\text { OSTEOMA CONN. TISSUE SITE SPECIFIED IN } \\
\text { COMMENT }\end{array}$ & $\mathbf{P}$ & $1 \times 200$ & M91800 & & CONNECTIVE TISSUE * OSTEOMA & \\
\hline TCSS & $\begin{array}{l}\text { UNDIFERRENTIATED CONNECTIVE TISSUE } \\
\text { SARCOMA SITE SPEC. IN CO. }\end{array}$ & $\mathbf{P}$ & $1 \times 200$ & M88053 & & $\begin{array}{l}\text { CONNECTIVE TISSUE * } \\
\text { UNDIFEERENIIATED SARCOMA }\end{array}$ & \\
\hline TCVo & $\begin{array}{l}\text { HEMANGIOMA, BENIGN; CONN. TISS. SITE } \\
\text { SPECIFIED IN COMMENT }\end{array}$ & $\mathbf{P}$ & $1 \times 200$ & M91200 & & CONNECTIVE TISSUE * HEMANGIOMA & \\
\hline TCVS & $\begin{array}{l}\text { HEMANGIOENDOTHELIOMA (ANGIOSARCOMA) MALIG } \\
\text { CONN TISS SITE SPEC }\end{array}$ & $\mathbf{P}$ & $1 \times 200$ & M91203 & & CONNECTIVE TISSUE * ANGIOSARCOMA & \\
\hline TCWA & $\begin{array}{l}\text { ADRENAI ORIGIN; CONN. TISS. MET. SITE } \\
\text { SPECIFIED IN COMNENT }\end{array}$ & $\mathbf{s}$ & $1 \times 200$ & & 93000 & CONNECTIVE TISSUE * & ADRENAL GLAND \\
\hline TCWB & $\begin{array}{l}\text { BONE ORIGIN IN COMM.; CONN.TISS. MET. } \\
\text { SITE SREC. IN COMM. }\end{array}$ & $\mathbf{s}$ & $1 \times 200$ & & $1 \times 500$ & CONNECTIVE TISSUE * & BONE \\
\hline TCWD & $\begin{array}{l}\text { URINARY BLADDER ORIGIN; CONN.TISS. MET. } \\
\text { SITE SPEC. IN COMS. }\end{array}$ & $\mathbf{s}$ & $1 \times 200$ & & 74000 & CONNECTIVE TISSUE * & URINARY BLADDER \\
\hline TCFG & $\begin{array}{l}\text { HARDERIAN GLAND ORIGIN; CONN. TISS. MET. } \\
\text { SITE SPEC. IN COMMTI }\end{array}$ & $\mathbf{s}$ & $1 \times 200$ & & $x \times 836$ & CONRECTIVE TISSUE * & HARDERIAN GLAND \\
\hline TCWH & $\begin{array}{l}\text { IIVERR ORIGIN; CONN TISS. MET. SITE SPEC. } \\
\text { IN COMUET }\end{array}$ & $\mathbf{s}$ & $1 \times 200$ & & 56000 & CONRECTIVE TISSUE * & LIVER \\
\hline
\end{tabular}




\begin{tabular}{|c|c|c|c|c|c|c|c|}
\hline $\begin{array}{l}\text { JANOS } \\
\text { Code }\end{array}$ & JANUS Description & $\begin{array}{l}P \\
S \\
N\end{array}$ & $\begin{array}{ll}T & s \\
0 & 1 \\
p & t \\
0 & e \\
g & \\
0 & \end{array}$ & $\begin{array}{l}M \\
o \\
x \\
p \\
b \\
.\end{array}$ & 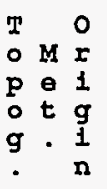 & SNOMED Description & $\begin{array}{l}\text { Metastatic } \\
\text { Origin }\end{array}$ \\
\hline TCWI & $\begin{array}{l}\text { GI TRACT ORIGIN IN COMMENT; CONN.NISS. } \\
\text { MET. SITE SPEC. IN C. }\end{array}$ & $\mathbf{s}$ & $1 \times 200$ & & 50100 & CONNECTIVE TISSUE * & GI TRACT \\
\hline TCWK & $\begin{array}{l}\text { KIDNEY ORIGIN; CONN. TISS. MET. SITE } \\
\text { SPEC. IN COMMENT }\end{array}$ & $\mathbf{s}$ & $1 \times 200$ & & 71000 & CONNECTIVE TISSUE * & KIDNEY \\
\hline TCWN & $\begin{array}{l}\text { NERVOUS SYSTEM ORIGIN IN COMNENT; } \\
\text { CONN. TISS. MET. SITE SPEC. }\end{array}$ & s & $1 \times 200$ & & xoo00 & CONNECTIVE TISSUE * & NERVOUS SYSTEM \\
\hline TCWO & $\begin{array}{l}\text { OVARY ORIGIN; CONN. TISS. MET. SITE } \\
\text { SPEC. IN COMMENT }\end{array}$ & $\mathbf{s}$ & $1 \times 200$ & & 87000 & CONNECTIVE TISSUE * & OVARY \\
\hline TCFP & $\begin{array}{l}\text { PITUITARY ORIGIN; CONN.TISS. MET. SITE } \\
\text { SPEC. IN COMMENT }\end{array}$ & $\mathbf{s}$ & $1 \times 200$ & & 91000 & CONNECTIVE TISSUE * & PITUITARY \\
\hline TCWR & $\begin{array}{l}\text { RESPIRATORY SYSTEM ORIGIN; CONN. TISS. } \\
\text { MET. SITE SPEC. IN CT }\end{array}$ & $\mathbf{s}$ & $1 \times 200$ & & 20000 & CONNECTIVE TISSUE * & RESPIRATORY TRACT \\
\hline TCWS & $\begin{array}{l}\text { SKIN ORIGIN IN COMMENT; CONN. TISS. MET. } \\
\text { SITE SPBC. IN COMM. }\end{array}$ & $\mathbf{s}$ & $1 \times 200$ & & 01000 & CONNECTIVE TISSUE * & SKIN \\
\hline TCWZ & $\begin{array}{l}\text { THYROID ORIGIN; CONN. TISS. MET. SITE } \\
\text { SPEC. IN COMMENT }\end{array}$ & $\mathbf{s}$ & $1 \times 200$ & & 96000 & CONNECTIVE TISSUE * & THYROID \\
\hline TDEC & SQUAMOUS CELI CARCINOMA URINARY BLADDER & $\mathbf{P}$ & 74000 & M80703 & & $\begin{array}{l}\text { URINARY BLADDER * SQUAMOUS } \\
\text { CARCINOMA }\end{array}$ & \\
\hline $\begin{array}{l}\text { TDES } \\
\text { TDLS } \\
\text { TDTC }\end{array}$ & $\begin{array}{l}\text { FIBROSARCOMA URINARY BLADDER } \\
\text { LEIOMYOSARCOMA URINARY BLADDER } \\
\text { TRANSITIONAL CELL CARCINOMA URINARY } \\
\text { BLADDER }\end{array}$ & $\begin{array}{l}\mathbf{P} \\
\mathbf{P} \\
\mathbf{P}\end{array}$ & $\begin{array}{l}74000 \\
74000 \\
74000\end{array}$ & $\begin{array}{l}\text { M88103 } \\
\text { M88903 } \\
\text { M81203 }\end{array}$ & & $\begin{array}{l}\text { URINARY BLADDER * FIBROSARCOMA } \\
\text { URINARY BLAADDRR * LEIOMYOSARCOMA } \\
\text { URINARY BLADDER * TRANSITIONAI } \\
\text { CARCINOMA }\end{array}$ & \\
\hline TDVO & $\begin{array}{l}\text { VASCULAR TUMOR URINARY BLADDER } \\
\text { (HEMANGIOMA) }\end{array}$ & $\mathbf{P}$ & 74000 & M91200 & & URINARY BLADDER * HEMANGIOMA & \\
\hline TDVS & $\begin{array}{l}\text { VASCULLAR TUMOR, ANGIOSARCOMA URINARY } \\
\text { BLADDER }\end{array}$ & $\mathbf{P}$ & 74000 & M91203 & & URINARY BLADDER * ANGIOSARCOMA & \\
\hline TDWX & $\begin{array}{l}\text { TISS. OF ORIGIN IN COMMENT; MET. TO } \\
\text { URINARY BIADDER }\end{array}$ & $\mathbf{s}$ & 74000 & & 00003 & URINARY BLADDDER * & - NOT ASSIGNED - \\
\hline $\begin{array}{l}\text { TEFS } \\
\text { TEVO }\end{array}$ & $\begin{array}{l}\text { FIBROSARCOMA OF SPLLEN } \\
\text { VASCUTAR TUMOR OF SPLEEN, BENIGN } \\
\text { (BRMANGIOMA) }\end{array}$ & $\stackrel{P}{P}$ & $\begin{array}{l}07000 \\
07000\end{array}$ & $\begin{array}{l}\text { M88103 } \\
\text { M91200 }\end{array}$ & & $\begin{array}{l}\text { SPLLEN * FIBROSARCOMA } \\
\text { SPLEEN * HEMANGIOMA }\end{array}$ & \\
\hline
\end{tabular}




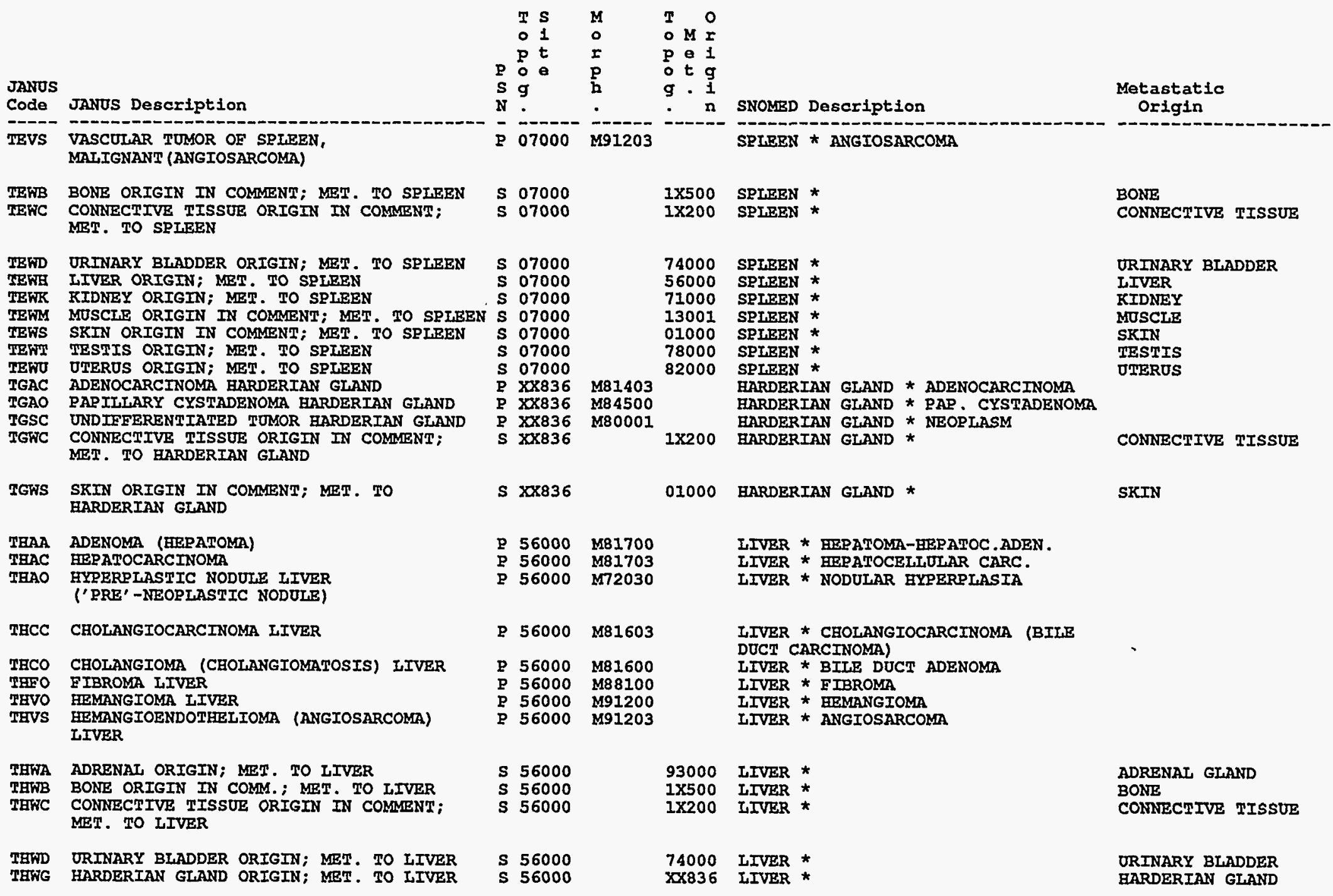




\begin{tabular}{|c|c|c|c|c|c|c|c|}
\hline $\begin{array}{l}\text { JANOS } \\
\text { Code }\end{array}$ & JANOS Description & $\begin{array}{l}\mathrm{P} \\
\mathrm{S} \\
\mathrm{N}\end{array}$ & $\begin{array}{ll}T & 5 \\
0 & 1 \\
\text { p } & t \\
0 & e \\
g & \\
. & \end{array}$ & $\begin{array}{l}\mathbf{M} \\
\circ \\
\mathbf{r} \\
\mathbf{p} \\
\mathrm{h} \\
\text {. }\end{array}$ & $\begin{array}{lll}T & & 0 \\
0 & M & r \\
p & 0 & 1 \\
0 & t & g \\
g & \cdot & 1 \\
\cdot & & n\end{array}$ & SNOMED Description & $\begin{array}{l}\text { Motastatio } \\
\text { Origin }\end{array}$ \\
\hline THFI & $\begin{array}{l}\text { GI TRACT ORIGIN IN COMMENT; MET. TO } \\
\text { IIVER }\end{array}$ & $\mathbf{s}$ & 56000 & & 50100 & LIVER * & GI TRACT \\
\hline $\begin{array}{l}\text { THWK } \\
\text { THWM } \\
\text { THWN }\end{array}$ & $\begin{array}{l}\text { KIDNEY ORIGIN; MET. TO LIVER } \\
\text { MUSCLE ORIGIN IN COMMENT; MET. TO LIVER } \\
\text { NERVOUS SYSTEM ORIGIN IN COMMENT; MET. } \\
\text { TO LIVER }\end{array}$ & $\begin{array}{l}\mathbf{s} \\
\mathbf{s} \\
\mathbf{s}\end{array}$ & $\begin{array}{l}56000 \\
56000 \\
56000\end{array}$ & & $\begin{array}{l}71000 \\
13001 \\
x 0000\end{array}$ & $\begin{array}{l}\text { IIVER * } \\
\text { IIVRR * } \\
\text { IIVER * }\end{array}$ & $\begin{array}{l}\text { KIDNEY } \\
\text { MOSCIE } \\
\text { NERVOUS SYSTEM }\end{array}$ \\
\hline $\begin{array}{l}\text { THWO } \\
\text { THWP } \\
\text { THWR } \\
\text { TEWS } \\
\text { THWO } \\
\text { THWV } \\
\text { THWX }\end{array}$ & $\begin{array}{l}\text { OVARY ORIGIN; MET. TO LIVER } \\
\text { PITUITARY ORIGIN; MET. TO IIVER } \\
\text { RBSPIRATORY SYSTEM ORIGIN; MRT. TO LIVER } \\
\text { SRIN ORIGIN IN COMMENT; MET. TO IIVER } \\
\text { UTEROS ORIGIN; MET. TO IIVER } \\
\text { SEMINAL VESICLE ORIGIN; MRT. TO LIVER } \\
\text { TISSUE OF ORIGIN IN COMMENT; MET. TO } \\
\text { IIVER }\end{array}$ & $\begin{array}{l}\mathbf{S} \\
\mathbf{S} \\
\mathbf{S} \\
\mathbf{S} \\
\mathbf{S} \\
\mathbf{S} \\
\mathbf{S}\end{array}$ & $\begin{array}{l}56000 \\
56000 \\
56000 \\
56000 \\
56000 \\
56000 \\
56000\end{array}$ & & $\begin{array}{l}87000 \\
91000 \\
20000 \\
01000 \\
82000 \\
77500 \\
00003\end{array}$ & $\begin{array}{l}\text { LIVER * } \\
\text { IIVER * } \\
\text { IIVER * } \\
\text { IIVER * } \\
\text { IIVER * } \\
\text { IIVER * } \\
\text { IIVER * }\end{array}$ & $\begin{array}{l}\text { OVARY } \\
\text { PITUITARY } \\
\text { RESPIRATORY TRACT } \\
\text { SKIN } \\
\text { OTERUS } \\
\text { SEMINAI VESICLE } \\
\text { - NOT ASSIGNED - }\end{array}$ \\
\hline $\begin{array}{l}\text { THWY } \\
\text { THWZ } \\
\text { TIAC }\end{array}$ & $\begin{array}{l}\text { HEART ORIGIN; MET TO LIVER } \\
\text { THYROID ORIGIN; MET. TO IIVER } \\
\text { ADENOCARCINOMA GI TRACT; SITE SPECIFIED } \\
\text { IN COMMENT }\end{array}$ & $\begin{array}{l}\mathbf{S} \\
\mathbf{S} \\
\mathbf{P}\end{array}$ & $\begin{array}{l}56000 \\
56000 \\
50100\end{array}$ & M81403 & $\begin{array}{l}32000 \\
96000\end{array}$ & $\begin{array}{l}\text { LIVER * } \\
\text { LIVER * } \\
\text { GI TRACT * ADENOCARCINOMA }\end{array}$ & $\begin{array}{l}\text { HEART } \\
\text { THYROID }\end{array}$ \\
\hline $\begin{array}{l}\text { TIAO } \\
\text { TIEC }\end{array}$ & $\begin{array}{l}\text { ADENOMA GI TRACT SITE SPEC. IN COMMENT } \\
\text { SQUAMOUS CELI CARCINOMA GI TRACT; SITE } \\
\text { SPECIFIED IN COMMENT }\end{array}$ & $\begin{array}{l}\mathbf{P} \\
\mathbf{P}\end{array}$ & $\begin{array}{l}50100 \\
50100\end{array}$ & $\begin{array}{l}\mathrm{M} 81400 \\
\mathrm{M} 80703\end{array}$ & & $\begin{array}{l}\text { GI TRACT * ADENOMA } \\
\text { GI TRACT * SQUAMOUS CARCINOMA }\end{array}$ & \\
\hline $\begin{array}{l}\text { TIFO } \\
\text { TIFS }\end{array}$ & $\begin{array}{l}\text { FIBROMA GI TRACT SITE SPEC. IN COMMENT } \\
\text { FIBROSARCOMA GI TRACT SITE SPECIFIED IN } \\
\text { COMMENT }\end{array}$ & $\begin{array}{l}\mathbf{P} \\
\mathbf{P}\end{array}$ & $\begin{array}{l}50100 \\
50100\end{array}$ & $\begin{array}{l}\text { M88100 } \\
\text { M88103 }\end{array}$ & & $\begin{array}{l}\text { GI TRACT * FIBROMA } \\
\text { GI TRACT * FIBROSARCOMA }\end{array}$ & \\
\hline TINO & $\begin{array}{l}\text { NEURILEMMOMA GI TRACT SITE SPECIFIED IN } \\
\text { COMUENT }\end{array}$ & $\mathbf{P}$ & 50100 & M95600 & & GI TRACT * SCEWARNOMA & \\
\hline $\begin{array}{l}\text { TIPL } \\
\text { TIPO }\end{array}$ & $\begin{array}{l}\text { PLAQUE (PYLORIC REGION; POLYP) GI TRACT } \\
\text { POLYPS GI TRACT SITE SPECIFIED IN } \\
\text { COMMENT }\end{array}$ & $\begin{array}{l}\mathbf{P} \\
\mathbf{P}\end{array}$ & $\begin{array}{l}50100 \\
50100\end{array}$ & $\begin{array}{l}M 72040 \\
M 76800\end{array}$ & & $\begin{array}{l}\text { GI TRACT * POLYPOID HYPERPIASIA } \\
\text { GI TRACT * POLYP }\end{array}$ & \\
\hline TISC & $\begin{array}{l}\text { ONDIFFERENTIATED CARCINOMA GI TRACT; } \\
\text { SITE SPEC. IN COMMENT }\end{array}$ & $\mathbf{P}$ & 50100 & M80203 & & GI TRACT * ONDIFE. CARCINOMA & \\
\hline TISO & $\begin{array}{l}\text { LEIOMYOMA GI TRACT SITE SPECIFIED IN } \\
\text { COMMBNT }\end{array}$ & $\mathbf{P}$ & 50100 & M88900 & & GI TRACT * IEIOMYOMA & \\
\hline TI & $\begin{array}{l}\text { LEIOMYOSARCOMA GI TRACT SITE SPEC. IN } \\
\text { COMMENT }\end{array}$ & $\mathbf{P}$ & 50100 & M88903 & & GI TRACT * IEIOMYOSAF & \\
\hline
\end{tabular}




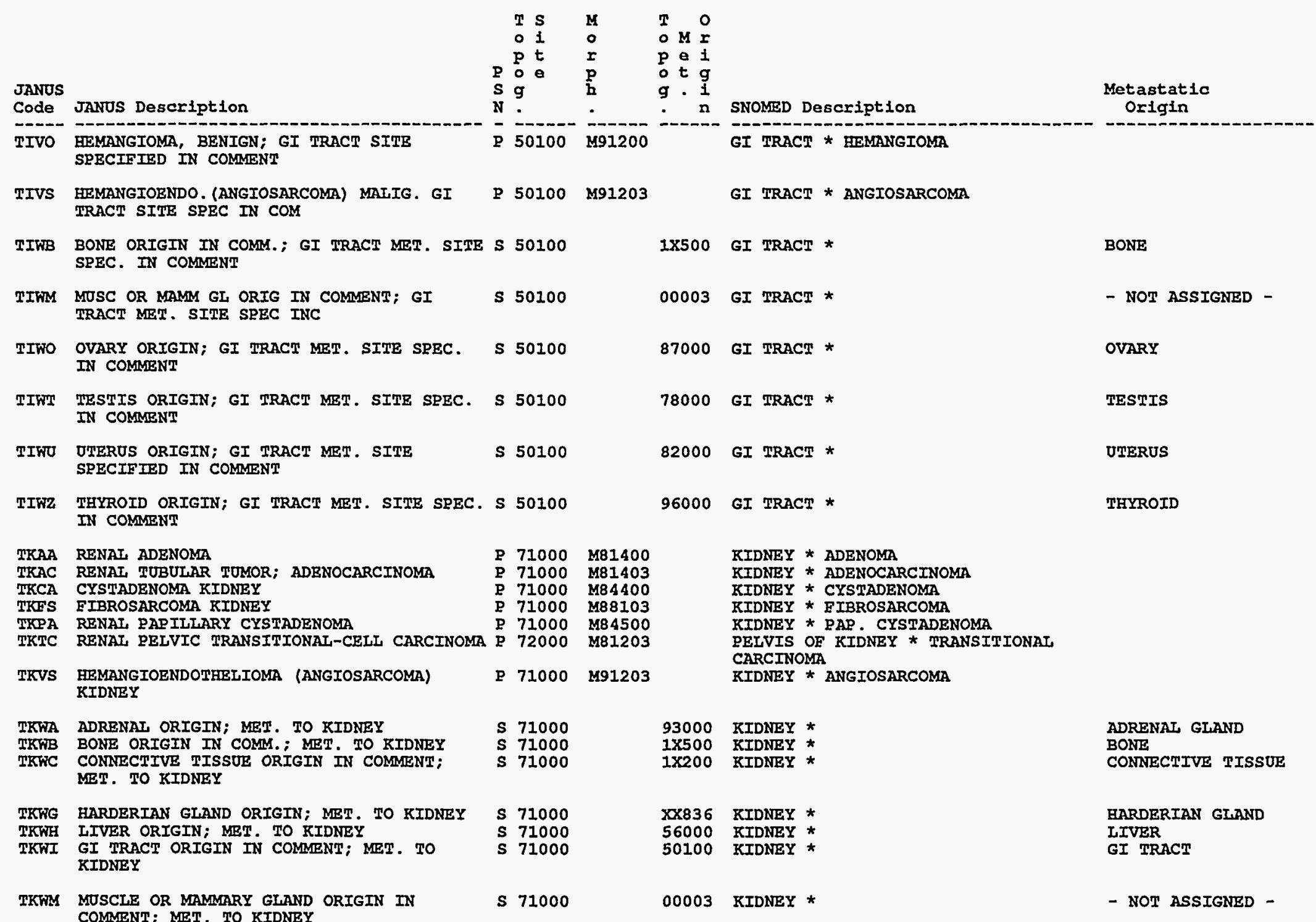




\begin{tabular}{|c|c|c|c|c|c|c|c|c|}
\hline $\begin{array}{l}\text { JANOS } \\
\text { Code }\end{array}$ & JANUS Description & $\begin{array}{l}\mathbf{P} \\
\mathbf{S} \\
\mathbf{N}\end{array}$ & $\begin{array}{ll}T & s \\
0 & i \\
p & t \\
0 & e \\
g & \\
\text {. } & \end{array}$ & $\begin{array}{l}\mathrm{M} \\
0 \\
\mathbf{x} \\
\mathrm{p} \\
\mathbf{b} \\
.\end{array}$ & $\begin{array}{lll}T & & 0 \\
0 & M & r \\
p & 0 & 1 \\
0 & t & g \\
g & \cdot & 1 \\
\cdot & & n\end{array}$ & SNOMED & Description & $\begin{array}{c}\text { Metastatic } \\
\text { Origin }\end{array}$ \\
\hline TKWN & $\begin{array}{l}\text { NERVOUS SYSTEM ORIGIN IN COMMENT; MET. } \\
\text { TO KIDNEY }\end{array}$ & $\mathbf{s}$ & 71000 & & $\times 0000$ & KIDNEY & * & NERVOUS SYSTEM \\
\hline $\begin{array}{l}\text { TKWO } \\
\text { TKKWP } \\
\text { TKKWR }\end{array}$ & $\begin{array}{l}\text { OVARY ORIGIN; MRT. TO KIDNEY } \\
\text { PITUITARY ORIGIN; MET. TO KIDNEY } \\
\text { RESPIRATORY SYSTEM ORIGIN; MET. TO } \\
\text { KIDNEY }\end{array}$ & $\begin{array}{l}\mathbf{S} \\
\mathbf{S} \\
\mathbf{S}\end{array}$ & $\begin{array}{l}71000 \\
71000 \\
71000\end{array}$ & & $\begin{array}{l}87000 \\
91000 \\
20000\end{array}$ & $\begin{array}{l}\text { KIDNEY } \\
\text { KIDNEY } \\
\text { KIDNEY }\end{array}$ & $\begin{array}{l}* \\
* \\
* \\
*\end{array}$ & $\begin{array}{l}\text { OVARY } \\
\text { PITUITARY } \\
\text { RESPIRATORY TRACT }\end{array}$ \\
\hline $\begin{array}{l}\text { TKWS } \\
\text { TKWU } \\
\text { TKWX }\end{array}$ & $\begin{array}{l}\text { SKIN ORIGIN IN COMMENT; MET. TO RIDNEY } \\
\text { UTERUS ORIGIN; MRT. TO KIDNEY } \\
\text { TISSUE OF ORIGIN IN COMMENT; MET. TO } \\
\text { KIDNEY }\end{array}$ & $\begin{array}{l}\mathbf{S} \\
\mathbf{S} \\
\mathbf{S}\end{array}$ & $\begin{array}{l}71000 \\
71000 \\
71000\end{array}$ & & $\begin{array}{l}01000 \\
82000 \\
00003\end{array}$ & $\begin{array}{l}\text { KIDNEY } \\
\text { KIDNEY } \\
\text { KIDNEY }\end{array}$ & $\begin{array}{l}* \\
* \\
*\end{array}$ & $\begin{array}{l}\text { SKIN } \\
\text { UTERUS } \\
\text { - NOT ASSIGNED - }\end{array}$ \\
\hline $\begin{array}{l}\text { TKW2 } \\
\text { TLFS }\end{array}$ & $\begin{array}{l}\text { THYROID ORIGIN; MET. TO KIDNEX } \\
\text { FIBROSARCOMA IYMPH NODE SITE SPECIFIED } \\
\text { IN COMMEN }\end{array}$ & $\begin{array}{l}\mathbf{S} \\
\mathbf{P}\end{array}$ & $\begin{array}{l}71000 \\
08000\end{array}$ & M88103 & 96000 & $\begin{array}{l}\text { KIDNEY } \\
\text { LYMPH }\end{array}$ & $\stackrel{*}{*}$ NODE $*$ FIBROSARCOMA & THYROID \\
\hline TLEL & $\begin{array}{l}\text { HISTIOCYTIC LEUKEMIA LYMPHORETICULAR } \\
\text { TISSUE }\end{array}$ & 2 & 05000 & M98903 & & $\begin{array}{l}\mathrm{R} / \mathrm{E} \& \mathrm{I} \\
\text { LEUKEM }\end{array}$ & $\underset{\text { IIA }}{\text { HEMATOP. SYSI. * MONOCYTIC }}$ & \\
\hline TLHS & $\begin{array}{l}\text { HISTIOCYTIC LYMPHOMA (RCT TYPE A) } \\
\text { LYMPHORET. TISSUE }\end{array}$ & $\mathbf{P}$ & 05000 & M96403 & & $\begin{array}{l}\mathrm{R} / \mathrm{E} \& \\
\text { HISTIO }\end{array}$ & $\begin{array}{l}\text { HEMATOP. SYST. * } \\
\text { XCYT. LYMPHOSARC. }\end{array}$ & \\
\hline TLLL & $\begin{array}{l}\text { LYMPHOCYTIC / LYMPHOBLASTIC IEUKRMIA; } \\
\text { IYMPHORETICULAR TISSUE }\end{array}$ & $P$ & 05000 & M98263 & & $\begin{array}{l}\text { R/E \& } \\
\text { LYMPHO } \\
\text { TYPE A }\end{array}$ & $\begin{array}{l}\text { HEMATOP. SYST . * } \\
\text { ACYT . IYMPEOBLAST . LEUK. (RCT } \\
\text { a) }\end{array}$ & \\
\hline TLLS & $\begin{array}{l}\text { LYMPHOCYTIC / LYMPHOBLASTIC IYMPHOMA } \\
\text { LYMPHORETICULAR TISS. }\end{array}$ & $\mathbf{P}$ & 05000 & M96993 & & $\begin{array}{l}\text { R/E \& } \\
\text { IYMPBOI }\end{array}$ & $\begin{array}{l}\text { HEMATOP. SYST. * LYMPHOCYTIC } \\
\text { OBLASTIC LYMPHOMA }\end{array}$ & \\
\hline TLML & $\begin{array}{l}\text { MYELOGENOUS LBUKEMIA； LYMPHORETICULAR } \\
\text { TISSUE }\end{array}$ & $\mathbf{P}$ & 05000 & M98603 & & $\begin{array}{l}R / E \& I \\
\text { LEUKEM }\end{array}$ & UEMATOR. SYST. * MYELOGENOUS & \\
\hline $\begin{array}{l}\text { TIPS } \\
\text { TLSL }\end{array}$ & $\begin{array}{l}\text { PLASMA CELC TUMOR LYMPHORETICULAR TISSUE } \\
\text { UNDIFERRENTIATED IEUKEMIA; } \\
\text { LYMPHORETICULAR TISSUE }\end{array}$ & $\begin{array}{l}\mathbf{P} \\
\mathbf{P}\end{array}$ & $\begin{array}{l}05000 \\
05000\end{array}$ & $\begin{array}{l}\text { M9731I } \\
\text { M98013 }\end{array}$ & & $\begin{array}{l}\mathrm{R} / \mathrm{E} \& \\
\mathrm{R} / \mathrm{E} \& \\
\text { UNDIFF }\end{array}$ & $\begin{array}{l}\text { HEMATOP. SYST. * PIASMACYTOMA } \\
\text { HEMATOP. SYST. * } \\
\text {.LEUKEMIA }\end{array}$ & \\
\hline TLSS & $\begin{array}{l}\text { UNDIFFBRENTIATED LYMPHOMA } \\
\text { LYMPHORETICULAR TISSUE }\end{array}$ & P & 05000 & M96003 & & $\begin{array}{l}\mathrm{R} / \mathrm{E} \& 1 \\
\text { ONDIFE? }\end{array}$ & $\begin{array}{l}\text { GEMATOP . SYST. * } \\
\text { PERENTIATED LYMPHOMA }\end{array}$ & \\
\hline TLOS & $\begin{array}{l}\text { ONCLASSIFIRD LYMPHOMA LYMPHORETICULAR } \\
\text { TISSUE }\end{array}$ & $\mathbf{P}$ & 05000 & M95903 & & $\begin{array}{l}\text { R/E \& } \\
\text { LYMPHOI }\end{array}$ & DEMATOP . SYST. * MALIGNANT & \\
\hline TLVO & $\begin{array}{l}\text { VASCULAR TUMOR, BENIGN (HEMANGTOMA); } \\
\text { LYMPHO.TISS. SITB SPEC.. }\end{array}$ & $\mathbf{P}$ & 05000 & M91200 & & $R / E \&$ & HEMATOR. SYST. * HEMANGIOMA & \\
\hline
\end{tabular}




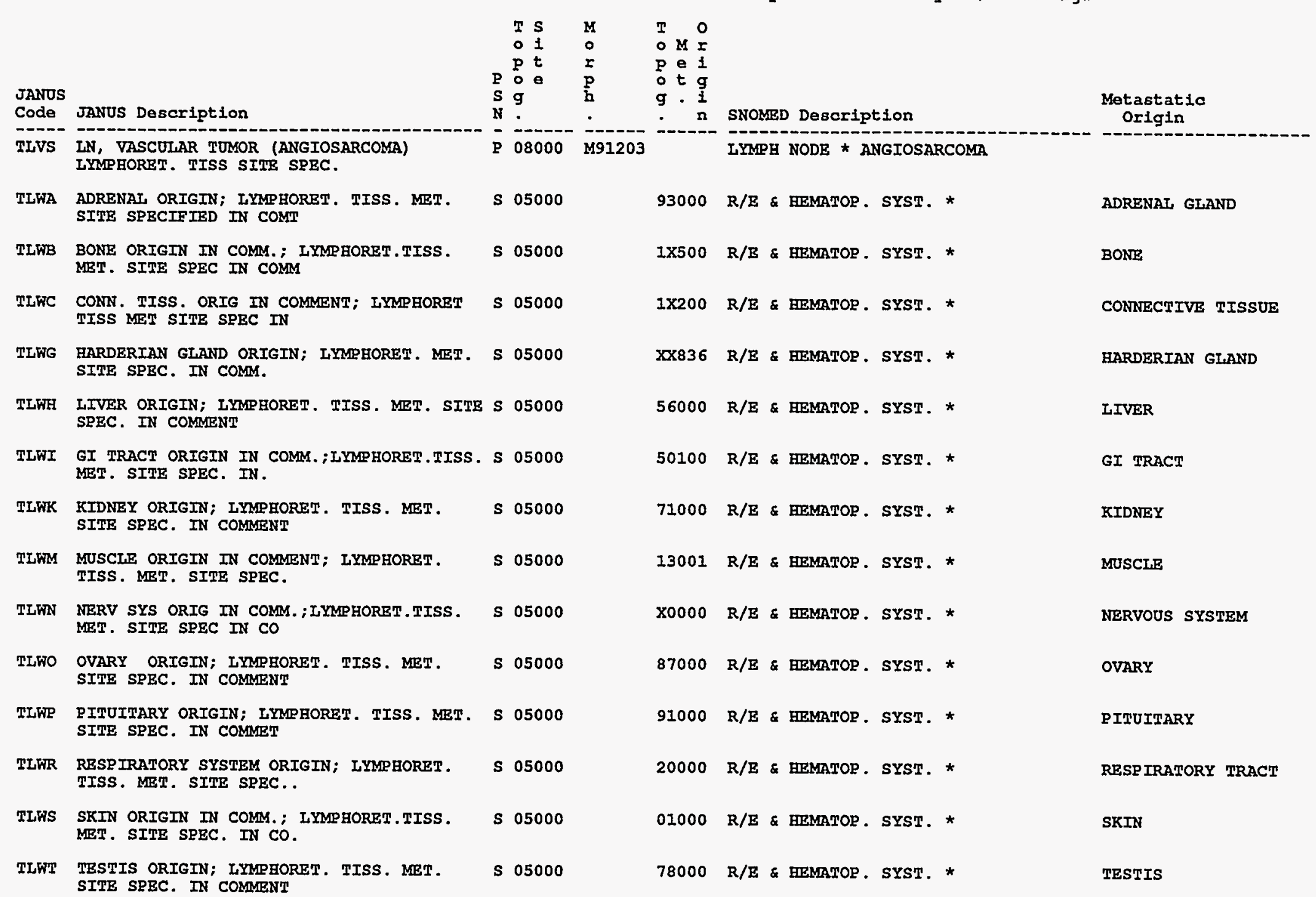




\begin{tabular}{|c|c|c|c|c|c|c|c|}
\hline $\begin{array}{ll}\text { Candes } \\
\text { Code }\end{array}$ & JANUS Description & $\begin{array}{l}\mathbf{P} \\
\mathbf{S} \\
\mathbb{N}\end{array}$ & $\begin{array}{ll}T & s \\
0 & 1 \\
p & t \\
0 & 0 \\
g & \\
0 & \end{array}$ & $\begin{array}{l}M \\
\dot{0} \\
r \\
P \\
b \\
.\end{array}$ & 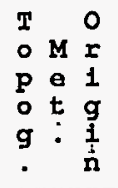 & SNOMED Description & $\begin{array}{l}\text { Mẹtastatic } \\
\text { Origin }\end{array}$ \\
\hline Iุ⿺辶寸 & $\begin{array}{l}\text { OTERUS ORIGIN; LYMPHORET. TISS. MET. } \\
\text { SITE SPEC. IN COMAMENT }\end{array}$ & $\mathbf{s}$ & 05000 & & 82000 & R/E \& HEMATOR. SYST. * & UTERUंS \\
\hline TLWX & $\begin{array}{l}\text { TISS OF ORIG IN COMMENT; LYMPHORET.TISS. } \\
\text { METT: STTE SPEC IN C }\end{array}$ & $\mathbf{s}$ & 05000 & & 00003 & R/E \& EEMATOP. SYST. * & - NOT ASSIGNED - \\
\hline TLWY & $\begin{array}{l}\text { HEART ORIGIN; LYMPHORRT. TISS. MET. SITE } \\
\text { SPEC. IN CQMENT }\end{array}$ & $\mathbf{s}$ & 0,5000 & & 32000 & R/E \& HEMATOP. SYST. * & GEART \\
\hline TLWZ & $\begin{array}{l}\text { THYROID ORIGIN; IMMPHORET. TISS. MRT. } \\
\text { SITE SPEC. IN COMMENT }\end{array}$ & $\mathbf{s}$ & 05000 & & $96 Q 00$ & R/E \& HEMATOP. SYST. * & THYROID \\
\hline TPL & 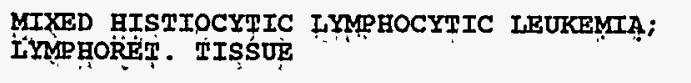 & $\mathbf{P}$ & 05000 & M98273 & & $\begin{array}{l}\text { R/E \& MEMATOR. SYST. * MIXED } \\
\text { HISTIOCYTIC LYMPHOCYTIC LEUKEMIA }\end{array}$ & \\
\hline TLXS & $\begin{array}{l}\text { MIXED HISTTOCYTIC LYMPHOCYTIC LYMPHOMA } \\
\text { (RCT TYPE B) }\end{array}$ & $\mathbf{P}$ & 05000 & M96133 & & $\begin{array}{l}\text { R/E \& HEMATOP. SYST. * MIXED } \\
\text { HISTIOCYTIC LYMPEOCYTIC LYMPHOMA }\end{array}$ & \\
\hline TMAPA & $\begin{array}{l}\text { ADENOCARCINOMA A (ALVEOLAR) MAMMARY } \\
\text { GLARND }\end{array}$ & $\mathbf{P}$ & 04000 & M82513 & & $\begin{array}{l}\text { MAMMARY GLAND * ALVEOLAR } \\
\text { ADENOCARCINOMA }\end{array}$ & \\
\hline TMAB & $\begin{array}{l}\text { ADENOCARCINOMA B (DUCTAL, PREDOMINANTLY) } \\
\text { MAMMARTY GLAND }\end{array}$ & $\mathbf{P}$ & 04000 & M85003 & & $\begin{array}{l}\text { MAMMARY GLAND * DUCTAL } \\
\text { ADENOCARCINOMA }\end{array}$ & \\
\hline TMAC & $\begin{array}{l}\text { ADENOCARCINOMA C (EIBROSARCOMA) MAMMARY } \\
\text { GLANP }\end{array}$ & $\mathbf{P}$ & 04000 & M88103 & & MATMMARY GLANDD * FIBROSARCOMA & \\
\hline $\begin{array}{l}\text { TMAT } \\
\text { TMFS }\end{array}$ & $\begin{array}{l}\text { ADENOACANTHOMA MAMMARY GLAND } \\
\text { FIBROSARCOMA MUSCLE SITE SRECIFIED IN } \\
\text { COMMENYI }\end{array}$ & $\begin{array}{l}\mathbf{P} \\
\mathbf{P}\end{array}$ & $\begin{array}{l}04000 \\
13001\end{array}$ & $\begin{array}{l}\text { M85703 } \\
\text { M88103 }\end{array}$ & & $\begin{array}{l}\text { MAMMARY GLAND * ADENOACANTHOMA } \\
\text { MUSCLE * FTBROSARCOMA }\end{array}$ & \\
\hline TMLS & $\begin{array}{l}\text { LETOMYOSARCOMA MQSCFE SITE SPECIFIED IN } \\
\text { COMMETY }\end{array}$ & $\mathbf{P}$ & 13001 & M88903 & & MUSCLE * LBTYOMYOSARCOMA & \\
\hline TMRO & $\begin{array}{l}\text { RHABPOMYOMA MUSCLE SIIE SPECIFIED IN } \\
\text { COMANET }\end{array}$ & $\mathbf{P}$ & 13001 & M89000 & & MUSCLE * RHABDOMYOMA & \\
\hline TMRS & $\begin{array}{l}\text { RHABDOMYOSARCOMA MUSCLPE SITE SPECIFIED } \\
\text { IN COMMENT }\end{array}$ & $\mathbf{P}$ & 13001 & M89003 & & MUSCLE * RMABDOMYOSARCOMA & \\
\hline TMSO & $\begin{array}{l}\text { LEIOMYOMA MUSCLE SITE ŞPECIFIED IN } \\
\text { COMMENT }\end{array}$ & $\mathbf{P}$ & 13001 & M88900 & & MOSCLE * LEIOMYOMA & \\
\hline TMSS & $\begin{array}{l}\text { ONDIFEERENTIATED SARCOMA MOSCLE SITE } \\
\text { SPECIF IED IN COMMENT! }\end{array}$ & $\mathbf{P}$ & 13001 & M88053 & & MUSCLE * UNDIFFEERENTIATED SA & \\
\hline
\end{tabular}




\begin{tabular}{|c|c|c|c|c|c|c|c|}
\hline $\begin{array}{l}\text { JANOS } \\
\text { Code }\end{array}$ & JANOS Description & $\begin{array}{l} \\
\mathbf{P} \\
\mathbf{S} \\
\mathbf{N}\end{array}$ & $\begin{array}{ll}T & s \\
0 & 1 \\
p & t \\
0 & 0 \\
g & \\
& \end{array}$ & $\begin{array}{l}\mathbf{M} \\
0 \\
\mathbf{r} \\
P \\
\mathbf{b} \\
.\end{array}$ & $\begin{array}{lll}T & & 0 \\
0 & M & r \\
P & e & i \\
0 & t & g \\
g & \cdot & i \\
\cdot & & n\end{array}$ & SNOMED Description & $\begin{array}{l}\text { Metastatic } \\
\text { Origin }\end{array}$ \\
\hline $\begin{array}{l}\text { TMNO } \\
\text { TMVO }\end{array}$ & $\begin{array}{l}\text { MAMMARY GLAND TUMOR (UNDETERMTNED TYPE) } \\
\text { HEMANGIOMA MOSCLE SITE SPECIFIED IN } \\
\text { COMMENT }\end{array}$ & $\underset{\mathbf{p}}{\mathbf{p}}$ & $\begin{array}{l}04000 \\
13001\end{array}$ & $\begin{array}{l}\text { M80001 } \\
\text { M91200 }\end{array}$ & & $\begin{array}{l}\text { MAMMARY GL.AND * NEOPLIASM } \\
\text { MUSCLE * GEMANGIOMA }\end{array}$ & \\
\hline TMvS & $\begin{array}{l}\text { HEMANGIOENDO (ANGIOSARCOMA), MALIG } \\
\text { MOSCIE SITE SPEC IN COMM }\end{array}$ & $\mathbf{P}$ & 13001 & M91203 & & MUSCLE * ANGIOSARCOMA & \\
\hline TMWA & $\begin{array}{l}\text { ADRENAL, ORIGIN; MUSCLE MET. SITB SPEC. } \\
\text { IN COMMENT }\end{array}$ & $\mathbf{s}$ & 13001 & & 93000 & MOSCLB * & ADRENAI GLAND \\
\hline TMWB & $\begin{array}{l}\text { BONE ORIGIN IN COMMENT; MUSCLE MET. SITE } \\
\text { SPEC. IN COMMENT }\end{array}$ & $\mathbf{s}$ & 13001 & & $1 \times 500$ & MUSCLE * & BONE \\
\hline TMFC & $\begin{array}{l}\text { CONN TISS ORIGIN IN COMM.;MOSCLE MET. } \\
\text { SITE SPEC. IN COMMENT }\end{array}$ & $\mathbf{s}$ & 13001 & & $1 \times 200$ & MUSCLE * & CONNECTIVE TISSOE \\
\hline TMKD & $\begin{array}{l}\text { URINARY BLADDER ORIGIN; MUSCLE MBT. SITE } \\
\text { SPECIFIED IN COMMET }\end{array}$ & $\mathbf{s}$ & 13001 & & 74000 & MUSCLE * & URINARY BLADDER \\
\hline TMWG & $\begin{array}{l}\text { EARDERIAN GLAND ORIGIN; MOSCLE MET. STTE } \\
\text { SPBCIFIED IN COMM. }\end{array}$ & $\mathbf{s}$ & 13001 & & $x \times 836$ & MOSCLE * & HARDERIAN GLAND \\
\hline TMWH & $\begin{array}{l}\text { IIVER ORIGIN; MUSCLE MET. SITE SPEC. IN } \\
\text { COMMENT }\end{array}$ & $\mathbf{s}$ & 13001 & & 56000 & MUSCLE * & IIVER \\
\hline TMWK & $\begin{array}{l}\text { KIDNEY ORIGIN; MOSCLE MET. SITE } \\
\text { SPECIFIED IN COMMENT }\end{array}$ & $\mathbf{s}$ & 13001 & & 71000 & MOSCLE * & KIDNEY \\
\hline TMWM & $\begin{array}{l}\text { MAMMARY GIAND ORIGIN; MOSCLE MET. SITE } \\
\text { SPEC. IN COMMENT }\end{array}$ & $\mathbf{s}$ & 13001 & & 04000 & MOSCLE * & MAMMARY GLAND \\
\hline TMFN & $\begin{array}{l}\text { NERVOUS SYSTEM ORIGIN IN COMM.; MOSCLE } \\
\text { MET. SITE SPEC. IN C. }\end{array}$ & $\mathbf{s}$ & 13001 & & 80000 & MOSCLE * & NERVOUS SYSTEM \\
\hline TMWR & $\begin{array}{l}\text { RESPIRATORY SYSTEM ORIGIN; MUSCLE MET. } \\
\text { SITE SPEC. IN COMMENT }\end{array}$ & $\mathbf{s}$ & 13001 & & 20000 & MOSCLE * & RESPIRATORY TRACT \\
\hline TMWS & $\begin{array}{l}\text { SKIN ORIGIN IN COMMENT; MUSCLE MET. SITE } \\
\text { SPEC. IN COMMENT }\end{array}$ & $\mathbf{s}$ & 13001 & & 01000 & MOSCLE * & SKIN \\
\hline TMWT & $\begin{array}{l}\text { TESTIS ORIGIN; MOSCLE MET. SITE } \\
\text { SEECIFIED IN COMMENT }\end{array}$ & $\mathbf{s}$ & 13001 & & 78000 & MUSCLE * & TESTIS \\
\hline TMAX & $\begin{array}{l}\text { TISSUE OF ORIGIN IN COMMENT; MOSCLE MET. } \\
\text { SITE SPEC. IN COMM. }\end{array}$ & $\mathbf{s}$ & 13001 & & 00003 & MUSCLE * & - NOT AS \\
\hline
\end{tabular}




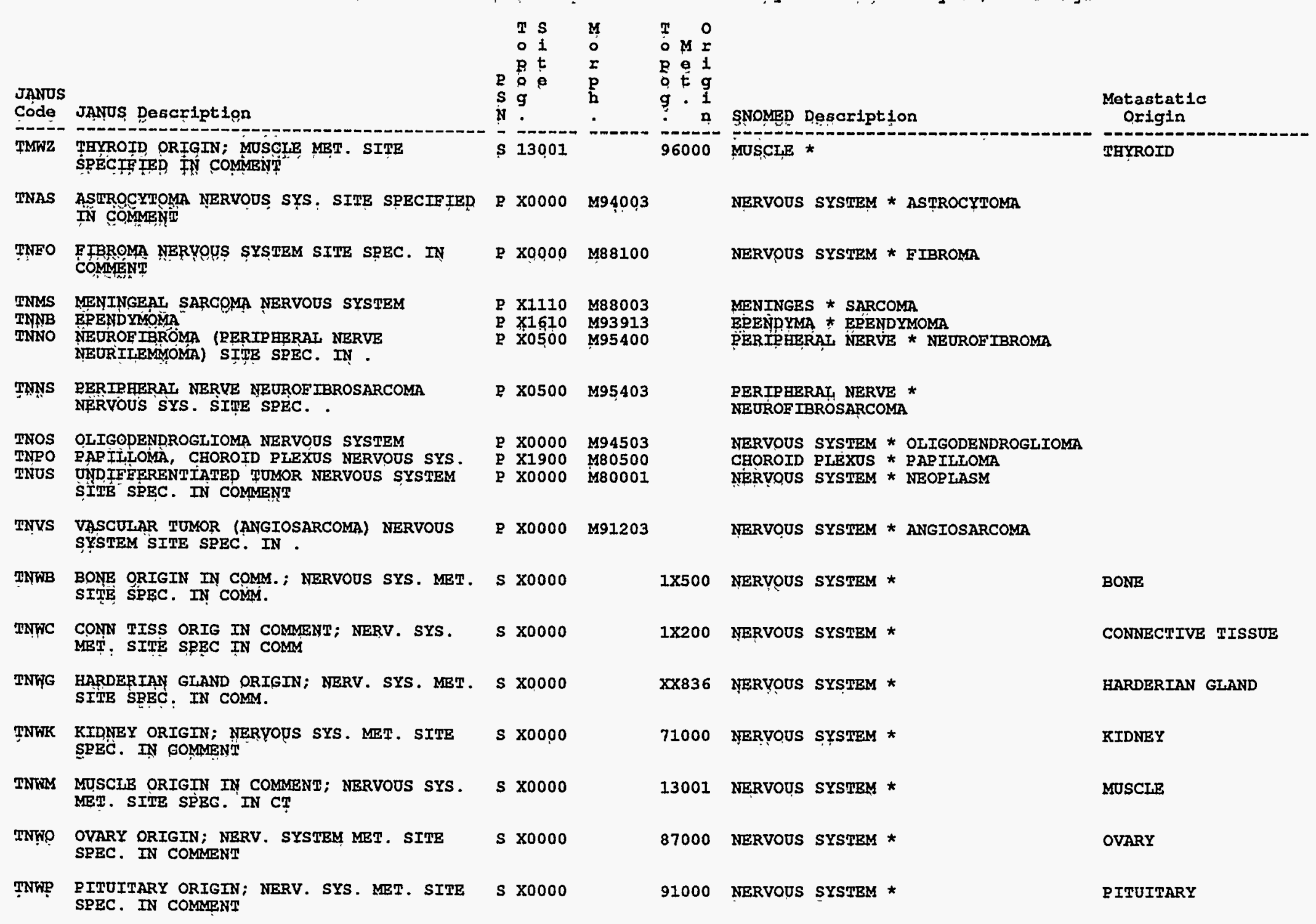




\begin{tabular}{|c|c|c|c|c|c|c|}
\hline $\begin{array}{l}\text { JANUS } \\
\text { Code }\end{array}$ & JANOS Description & $\begin{array}{lll} & T & S \\
0 & 1 \\
P & t \\
P & 0 & e \\
S & g \\
N & \end{array}$ & $\begin{array}{l}M \\
\circ \\
r \\
\mathrm{p} \\
\mathrm{h} \\
.\end{array}$ & 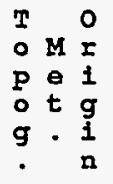 & SNOMBD Description & $\begin{array}{l}\text { Metastatio } \\
\text { Origin }\end{array}$ \\
\hline TNWR & $\begin{array}{l}\text { RESPIRATORY SYSTRM ORIGIN; NERV. SYS. } \\
\text { MET. SITE SPEC. IN CO. }\end{array}$ & s $\times 0000$ & & 20000 & NERVOUS SYSTEM * & RESPIRATORY TRACT \\
\hline TNWS & $\begin{array}{l}\text { SKIN ORIGIN IN COMMENT; NERV. SYS. MET. } \\
\text { SITE SREC. IN COMMET }\end{array}$ & S $\times 0000$ & & 01000 & NERVOUS SYSTEM * & SKIN \\
\hline TNWX & $\begin{array}{l}\text { TISSUE OF ORIGIN IN COMMENT; NERV. SYS. } \\
\text { MET. SITE SPEC. IN . }\end{array}$ & s $\times 0000$ & & 00003 & NERVOUS SYSTEM * & - NOT ASSIGNED - \\
\hline $\begin{array}{l}\text { TNXS } \\
\text { TOAC } \\
\text { TOAO } \\
\text { TOCO } \\
\text { TOGC } \\
\text { TOPA } \\
\text { TOSC } \\
\text { TOTA } \\
\text { TOTO } \\
\text { TOVO } \\
\text { TOVS }\end{array}$ & $\begin{array}{l}\text { GLIOMA, MIXED, NERVODS SYSTEM } \\
\text { ADENOCARCINOMA OVARY } \\
\text { ADENOMA OVARY } \\
\text { CYSTADENOMA OVARY } \\
\text { GRANULOSA CELL TUMOR OVARY } \\
\text { PAPILIARY ADENOMA OVARY } \\
\text { UNDIFFERENTIATED CARCINOMA OVARY } \\
\text { TUBULAR ADENOMA OVARY } \\
\text { LUTEOMA (THECOMA) OVARY } \\
\text { EEMANGIOMA OVARY } \\
\text { HEMANGIOENDOTEELIOMA (ANGIOSARCOMA) } \\
\text { OVARY }\end{array}$ & $\begin{array}{ll}\text { P } & X 0000 \\
\text { P } & 87000 \\
\text { P } & 87000 \\
\text { P } & 87000 \\
\text { P } & 87000 \\
\text { P } & 87000 \\
\text { P } & 87000 \\
\text { P } & 87000 \\
\text { P } & 87000 \\
\text { P } & 87000 \\
\text { P } & 87000\end{array}$ & $\begin{array}{l}\text { M93823 } \\
\text { M81403 } \\
\text { M81400 } \\
M 84400 \\
\text { M86201 } \\
\text { M82600 } \\
\text { M80203 } \\
\text { M82110 } \\
\text { M86100 } \\
\text { M91200 } \\
\text { M91203 }\end{array}$ & & $\begin{array}{l}\text { NERVOUS SYSTEM * MIXRD GLIOMA } \\
\text { OVARY * ADENOCARCINOMA } \\
\text { OVARY * ADENOMA } \\
\text { OVARY * CYSTADENOMA } \\
\text { OVARY * GRANULOSA CELI TUMOR } \\
\text { OVARY * PAPILIARY ADENOMA } \\
\text { OVARY * UNDIFE. CARCINOMA } \\
\text { OVARY * TUBULAR ADENOMA } \\
\text { OVARY * LUTEOMA } \\
\text { OVARY * HEMANGIOMA } \\
\text { OVARY * ANGIOSARCOMA }\end{array}$ & \\
\hline $\begin{array}{l}\text { TOWB } \\
\text { TOWU } \\
\text { TOWX }\end{array}$ & $\begin{array}{l}\text { BONE ORIGIN IN COMM.; MRT. TO OVARY } \\
\text { OTERUS ORIGIN; MET. TO OVARY } \\
\text { TISSUE OE ORIGIN IN COMMENT; MET. TO } \\
\text { OVARY }\end{array}$ & $\begin{array}{l}\text { S } 87000 \\
\text { S } 87000 \\
\text { S } 87000\end{array}$ & & $\begin{array}{l}1 \times 500 \\
82000 \\
00003\end{array}$ & $\begin{array}{l}\text { OVARY * } \\
\text { OVARY * } \\
\text { OVARY * }\end{array}$ & $\begin{array}{l}\text { BONE } \\
\text { UTRRUS } \\
\text { - NOT ASSIGNED - }\end{array}$ \\
\hline $\begin{array}{l}\text { TPAA } \\
\text { TPAC } \\
\text { TPAO } \\
\text { TPVS } \\
\text { TRAA } \\
\text { TRAC }\end{array}$ & $\begin{array}{l}\text { ACIDOPHILIC ADENOMA PITUITARY } \\
\text { CARCINOMA PITUITARY } \\
\text { ADENOMA PITUITARY } \\
\text { ANGIOSARCOMA PITUITARY } \\
\text { ALVEOLOGENIC TUMOR, BENIGN (ADENOMA) } \\
\text { ALVEOLOGENIC TUMOR, MALIGNANT } \\
\text { (ADENOCARCINOMA) }\end{array}$ & $\begin{array}{ll}P & 91000 \\
P & 91000 \\
P & 91000 \\
P & 91000 \\
P & 28000 \\
\text { P } & 28000\end{array}$ & $\begin{array}{l}M 82800 \\
M 80103 \\
M 81400 \\
M 91203 \\
M 81400 \\
M 81403\end{array}$ & & $\begin{array}{l}\text { PITUITARY * ACIDOPHILIC ADENOMA } \\
\text { PITUITARY * CARCINOMA } \\
\text { PITUITARY * ADENOMA } \\
\text { PITUITARY * ANGIOSARCOMA } \\
\text { IUNG * ADENOMA } \\
\text { IUNG * ADENOCARCINOMA }\end{array}$ & \\
\hline $\begin{array}{l}\text { TRCO } \\
\text { TRVS } \\
\text { TRWA } \\
\text { TRWB } \\
\text { TRWC }\end{array}$ & $\begin{array}{l}\text { CYSTADENOMA IUNG } \\
\text { VASCULAR TUMOR (ANGIOSARCOMA) IUNG } \\
\text { ADRENAI ORIGIN; MET. TO LUNG } \\
\text { BONE ORIGIN IN COMM.; MET. TO LUNG } \\
\text { CONRECTIVE TISSUE ORIGIN IN COMMENT; } \\
\text { MET. TO LUNG }\end{array}$ & $\begin{array}{ll}\text { P } & 28000 \\
\text { P } & 28000 \\
\text { S } & 28000 \\
\text { S } & 28000 \\
\text { S } & 28000\end{array}$ & $\begin{array}{l}\text { M84400 } \\
\text { M91203 }\end{array}$ & $\begin{array}{l}93000 \\
1 \times 500 \\
1 \times 200\end{array}$ & $\begin{array}{l}\text { LUNG * CYSTADENOMA } \\
\text { LUNG * ANGIOSARCOMA } \\
\text { LUNG * } \\
\text { LUNG * } \\
\text { LUNG * }\end{array}$ & $\begin{array}{l}\text { ADRENAL GLAND } \\
\text { BONE } \\
\text { CONRECTIVE TISSUE }\end{array}$ \\
\hline $\begin{array}{l}\text { TRWG } \\
\text { TRWR } \\
\text { TRWI }\end{array}$ & $\begin{array}{l}\text { HARDERIAN GLAND ORIGIN; MET. TO LUNG } \\
\text { LIVER ORIGIN; MET. TO LUNG } \\
\text { GI TRACT ORIGIN IN COMMENT; MET. TO LUNG }\end{array}$ & $\begin{array}{l}\text { s } 28000 \\
\text { S } 28000 \\
\text { s } 28000\end{array}$ & & $\begin{array}{l}\mathbf{X x 8 3 6} \\
56000 \\
50100\end{array}$ & $\begin{array}{l}\text { IUNG * } \\
\text { IUNG * } \\
\text { LONG * }\end{array}$ & $\begin{array}{l}\text { HARDERIAN GLAND } \\
\text { LIVER } \\
\text { GI TRACT }\end{array}$ \\
\hline
\end{tabular}




\begin{tabular}{|c|c|c|c|c|c|c|c|}
\hline $\begin{array}{l}\text { JANUS } \\
\text { Code }\end{array}$ & JANOS Description & $\begin{array}{l}P \\
S \\
N\end{array}$ & $\begin{array}{ll}T & s \\
0 & 1 \\
p & t \\
0 & e \\
g & \end{array}$ & $\begin{array}{l}\mathrm{M} \\
0 \\
\mathrm{x} \\
\mathrm{P} \\
\mathrm{b} \\
\text {. }\end{array}$ & 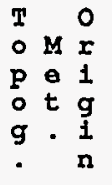 & SNOMED Description & $\begin{array}{l}\text { Metastatio } \\
\text { Origin }\end{array}$ \\
\hline $\begin{array}{l}\text { TRWK } \\
\text { TRWM }\end{array}$ & $\begin{array}{l}\text { KIDNEY ORIGIN; MET. TO LUNG } \\
\text { MOSCLE OR MAMMARY GLAND ORIGIN IN } \\
\text { COMMENT; MET. TO LUNG }\end{array}$ & $\begin{array}{l}\mathbf{S} \\
\mathbf{S}\end{array}$ & $\begin{array}{l}28000 \\
28000\end{array}$ & & $\begin{array}{l}71000 \\
00003\end{array}$ & $\begin{array}{l}\text { LUNG * } \\
\text { LUNG * }\end{array}$ & $\begin{array}{l}\text { RIDNEY } \\
\text { - NOT ASSIGNED - }\end{array}$ \\
\hline TRFN & $\begin{array}{l}\text { NERVOUS SYSTEM ORIGIN IN COMMENT; MET. } \\
\text { TO LONG }\end{array}$ & $\mathbf{s}$ & 28000 & & $\mathrm{x} 0000$ & LONG * & NERVOUS SYSTEM \\
\hline $\begin{array}{l}\text { TRWO } \\
\text { TRFP } \\
\text { TRWS } \\
\text { TRWT } \\
\text { TRWU } \\
\text { TRWV } \\
\text { TRWX }\end{array}$ & $\begin{array}{l}\text { OVARY ORIGIN; MET. TO LUNG } \\
\text { PITUITARY ORIGIN; MET. TO LUNG } \\
\text { SKIN ORIGIN IN COMMET; MET. TO LUNG } \\
\text { TESTIS ORIGIN; MET. TO LUNG } \\
\text { UTEROS ORIGIN; MET. TO LUNG } \\
\text { SEMTNAI VESICLE ORIGIN; MET. TO LUNG } \\
\text { TISSUE OF ORIGIN IN COMMENT; MET. TO } \\
\text { LUNG }\end{array}$ & $\begin{array}{l}\mathbf{S} \\
\mathbf{S} \\
\mathbf{S} \\
\mathbf{S} \\
\mathbf{S} \\
\mathbf{S} \\
\mathbf{S}\end{array}$ & $\begin{array}{l}28000 \\
28000 \\
28000 \\
28000 \\
28000 \\
28000 \\
28000\end{array}$ & & $\begin{array}{l}87000 \\
91000 \\
01000 \\
78000 \\
82000 \\
77500 \\
00003\end{array}$ & $\begin{array}{l}\text { IUNG * } \\
\text { LUNG * } \\
\text { LUNG * } \\
\text { LUNG * } \\
\text { LUNG * } \\
\text { IUNG * } \\
\text { LUNG * }\end{array}$ & $\begin{array}{l}\text { OVARY } \\
\text { PITUITARY } \\
\text { SKIN } \\
\text { TESTIS } \\
\text { OTERUS } \\
\text { SEMINAL VESICLE } \\
\text { - NOT ASSIGNED - }\end{array}$ \\
\hline $\begin{array}{l}\text { TRWY } \\
\text { TRNZ } \\
\text { TSAO } \\
\text { TSBC }\end{array}$ & $\begin{array}{l}\text { HEART ORIGIN; MET. TO IUNG } \\
\text { THYROID ORIGIN; MET. TO LUNG } \\
\text { ADENOMA SKIN SITE SPEC. IN COMMENT } \\
\text { BASAL CEIL CARCINOMA (HATR FOLLICLE } \\
\text { TUMOR) SITE SPEC. IN COMM }\end{array}$ & $\begin{array}{l}\mathbf{S} \\
\mathbf{S} \\
\mathbf{P} \\
\mathbf{P}\end{array}$ & $\begin{array}{l}28000 \\
28000 \\
01000 \\
01414\end{array}$ & $\begin{array}{l}\text { M81400 } \\
\text { M80903 }\end{array}$ & $\begin{array}{l}32000 \\
96000\end{array}$ & $\begin{array}{l}\text { LUNG * } \\
\text { LUNG * } \\
\text { SRIN * ADENOMA } \\
\text { HAIR FOILICLE * BASAL CARCINOMA }\end{array}$ & $\begin{array}{l}\text { GEART } \\
\text { THYROID }\end{array}$ \\
\hline TSDO & $\begin{array}{l}\text { SEBACEOUS (GLAAND) ADENOMA SKIN SITE } \\
\text { SPEC. IN COMMENT }\end{array}$ & $\mathbf{P}$ & 01310 & M84100 & & SEBACEOUS GLAND * SEBACEOUS ADENOMA & \\
\hline TSEC & $\begin{array}{l}\text { SQOAMOUS CELL CARCINOMA SKIN; SITE } \\
\text { SPECIFIED IN COMMENT }\end{array}$ & $\mathbf{P}$ & 01000 & M80703 & & SRIN * SQUAMOUS CARCINOMA & \\
\hline TSES & $\begin{array}{l}\text { FIBROSARCOMA SKIN SITE SPECIFIED IN } \\
\text { COMMIENT }\end{array}$ & $\mathbf{P}$ & 01000 & M88103 & & SKIN * FIBROSARCOMA & \\
\hline $\begin{array}{l}\text { TSPO } \\
\text { TSSS }\end{array}$ & $\begin{array}{l}\text { PAPILLOMA SKIN SITE SPECIFIED IN COMMENT } \\
\text { UNDIFFERENTIATED SARCOMA SKIN SITE } \\
\text { SPECIFIED IN COMMENT }\end{array}$ & $\begin{array}{l}\mathbf{P} \\
\mathbf{P}\end{array}$ & $\begin{array}{l}01000 \\
01000\end{array}$ & $\begin{array}{l}\text { M80500 } \\
\text { M88053 }\end{array}$ & & $\begin{array}{l}\text { SKIN * PAPILLOMA } \\
\text { SKIN * UNDIFEERENTIATED SARCOMA }\end{array}$ & \\
\hline TSVS & $\begin{array}{l}\text { VASCULAR TUMOR (ANGIOSARCOMA) SKIN SITE } \\
\text { SPEC. IN COMMENT }\end{array}$ & $\mathbf{P}$ & 01000 & M91203 & & SKIN * ANGIOSARCOMA & \\
\hline TSWB & $\begin{array}{l}\text { BONB ORIGIN IN COMM.; SKIN MET. SITE } \\
\text { SPECIFIED IN COMMENT }\end{array}$ & $\mathbf{s}$ & 01000 & & $1 \times 500$ & SKIN * & BONE \\
\hline TSWC & $\begin{array}{l}\text { CONNECTIVE TISSUE ORIGIN IN COMM.; SKIN } \\
\text { MET. SITE SPEC.IN C. }\end{array}$ & $\mathbf{s}$ & 01000 & & $1 \times 200$ & RIN * & CONNE \\
\hline
\end{tabular}




\begin{tabular}{|c|c|c|c|c|c|c|c|c|}
\hline $\begin{array}{l}\text { JANUS } \\
\text { Code }\end{array}$ & JANUS Description & $\begin{array}{ll} & 3 \\
& \\
P & \\
S & \\
N & \\
\end{array}$ & $\begin{array}{ll}T & S \\
0 & 1 \\
\text { P } & t \\
0 & 0 \\
g & \\
0 & \end{array}$ & $\begin{array}{l}M \\
0 \\
\mathbf{r} \\
\mathbf{p} \\
\mathbf{b} \\
\dot{-}\end{array}$ & $\begin{array}{lll}T & & 0 \\
0 & M & r \\
P & e & i \\
0 & t & g \\
g & . & i \\
0 & & n\end{array}$ & SNOMED D & Description & $\begin{array}{l}\text { Metastatic } \\
\text { Oxigin }\end{array}$ \\
\hline TSWN & $\begin{array}{l}\text { NERVOUS SYSTEM ORIGIN IN COMMENT; SKIN } \\
\text { MET. SITE SPEC. IN C. }\end{array}$ & $\mathbf{s}$ & 01000 & & $\mathrm{x} 0000$ & SKIN * & & NERVOUS SYSTEM \\
\hline TTAC & CARCINOMA TESTIS & $\mathbf{P}$ & 78000 & M80103 & & TESTIS $*$ & * CARCINOMA & \\
\hline TTEA & FIBROMA TESTIS & $\mathbf{P}$ & 78000 & M88100 & & TESTIS * & * FIBROMA & \\
\hline TIFS & FIBROSARCOMA TESTIS & $\mathbf{P}$ & 78000 & $\mathbf{M 8 8 1 0 3}$ & & TESTIS & * FIBROSARCOMa & \\
\hline TTGC & SEMINOMA TESTIS & $\mathbf{P}$ & 78000 & M90613 & & TESTIS $x$ & * SEMTNOMA. & \\
\hline THIO & INTERSTITIAL CELL TUMOR (LEYDIG) TESTIS & $\mathbf{P}$ & 78000 & M86500 & & TESTIS & * IEYDIG CELT TUMOR & \\
\hline TIKC & SERTOLI CEIL TUMOR TESTIS & & 78000 & M86400 & & TESTIS & * SERTOLI CELL TUMOR & \\
\hline TTQC & EMBRYONAL CARCINOMA TESTIS & $\mathbf{P}$ & 78000 & M90703 & & TESTIS & * EMBRYONAL CARCINOMA & \\
\hline TTVO & HEMANGIOMA, BENTGN TESTIS & $\mathbf{R}$ & 78000 & M91200 & & TESTIS & * HEMANGIOMA & \\
\hline TTVS & $\begin{array}{l}\text { HEMANGIOENDOTHELIOMA (ANGIOSARCOMA), } \\
\text { MALIGNANT TESTIS }\end{array}$ & $\mathbf{P}$ & 78000 & M91203 & & TESTIS & * ANGIOSARCOMA & \\
\hline TTYC & TERATOMA TESTIS & $\mathbf{p}$ & 78000 & M90801 & & TESTIS & * TERATOMA & \\
\hline TUAC & ADENOCARCINOMA UTERUS & $\mathbf{p}$ & 82000 & M81403 & & OTERUS & * ADENOCARCINOMA & \\
\hline TUAO & $\begin{array}{l}\text { ADENOMA (INCLUDING PAPILLARY TYPE) } \\
\text { UTERUS }\end{array}$ & $\mathbf{P}$ & 82000 & M81400 & & UTEROS & * ADENOMA & \\
\hline TUEC & SQUAMOUS CELL CARCINOMA OTERUS & $\mathbf{q}$ & 82000 & M80703 & & OTERUS & * SQUAMOUS CARCINOMA & \\
\hline TUEO & FIBROMA UTERUS & $\mathbf{P}$ & 82000 & M88100 & & UTERUS & * FIBROMa & \\
\hline TULO & LEIOMYOMA UTERUS & & 82000 & M88900 & & OTERUS & * IEIOMYOMA & \\
\hline TuLs & LEIOMYOSARCOMA UTEROS & $\mathrm{P}$ & 82000 & M88903 & & UTERUS & * LEIOMYOSARCOMA & \\
\hline TUNO & NEURIIEMMOMA UTEROS & $\mathrm{p}$ & 82000 & M95600 & & OTERUS & * SCHWANNOMA & \\
\hline TUUO & DECIDUOMATOSIS, JTEROS (DECIDUOMA) & $\mathbf{P}$ & 82000 & M76570 & & OTEROS & * DECIDDOMATOSIS & \\
\hline TUUS & SARCOMA， ONDETERMINED TYPE， OTEROS & $\mathbf{P}$ & 82000 & M88003 & & OTEROS & * SARComa & \\
\hline TUVO & EEMANGIOMA, BENIGN OTRRUS & $\mathbf{P}$ & 82000 & M91200 & & OTERUS & * HEMANGIOMA & \\
\hline TUVS & $\begin{array}{l}\text { HEMANGIOENDOTHELIOMA (ANGIOSARCOMA), } \\
\text { MALIGNANT UTERUS }\end{array}$ & $\mathbf{P}$ & 82000 & M91203 & & OTERUS & * ANGIOSARCOMa & \\
\hline TUWO & OVARY ORIGIN; MET. TO UTERUS & $\mathbf{s}$ & 82000 & & 87000 & OTERUS & * & OVARY \\
\hline TVAO & ADENOMA SEMINAL VESICIR & $\mathbf{P}$ & 77500 & M81400 & & SEMINAI & I VESICLE * ADENOMA & \\
\hline TVEO & FIBROMA SEMINAL VESICLE & & 77500 & M88100 & & SEMINAL & VESICLE * FIBROMA & \\
\hline TVFS & FIBROSARCOMA SEMINAI VESICLE & $\mathbf{P}$ & 77500 & M88103 & & SEMINAL & VESICLE * FIBROSARCOMA & \\
\hline TVSS & UNDIFEBRENTIATED SARCOMA SEMINAL VESICLE & $\mathbf{P}$ & 77500 & M88053 & & $\begin{array}{l}\text { SEMINAL } \\
\text { SARCOMA }\end{array}$ & VESICLE * UNDIFEERENTIATED & \\
\hline TVuo & $\begin{array}{l}\text { TUMOR (ONDETERMINED CELI TYPE) SEMTNAL } \\
\text { VESICLE }\end{array}$ & $\mathbf{P}$ & 77500 & M80001 & & SEMINAI & VESICLE * NEOPLASM & \\
\hline TVVS & $\begin{array}{l}\text { HEMANGIOENDOTHELIOMA } \\
\text { (ANGIOSARCOMA), MALIGNANT SEMINAL VESIC. }\end{array}$ & $\mathbf{P}$ & 77500 & M91203 & & SEMINAL & VESICLE * ANGIOSARCOMA & \\
\hline TVWD & $\begin{array}{l}\text { URINARY BLADDER ORIGIN; MET. TO SEMINAL } \\
\text { VESICLE }\end{array}$ & $\mathbf{s}$ & 77500 & & 74000 & SEMINAL & VESICLE * & URINARY BLADDER \\
\hline
\end{tabular}




\begin{tabular}{|c|c|c|c|c|c|c|c|}
\hline $\begin{array}{l}\text { JANOS } \\
\text { Code }\end{array}$ & JANUS Description & $\begin{array}{l} \\
\mathrm{P} \\
\mathrm{S} \\
\mathrm{N}\end{array}$ & $\begin{array}{ll}T & s \\
0 & 1 \\
p & t \\
0 & 0 \\
g & \\
0 & \end{array}$ & $\begin{array}{l}M \\
0 \\
r \\
p \\
b \\
.\end{array}$ & $\begin{array}{llll}T & & 0 \\
0 & M & r \\
P & e & 1 \\
0 & t & g \\
g & \cdot & i \\
\cdot & & & n\end{array}$ & SNOMED Description & $\begin{array}{l}\text { Metastatic } \\
\text { Origin }\end{array}$ \\
\hline TVWX & $\begin{array}{l}\text { TISSUE OF ORIGIN IN COMMENT; MET. TO } \\
\text { SEMINAL VESICLE }\end{array}$ & s. & 77500 & & 00003 & SEMTNAI VESICIE * & - NOT ASSIGNED - \\
\hline TXAC & $\begin{array}{l}\text { ADENOCARCINOMA RARE TISSUE WITH TUMOR } \\
\text { SITE SPEC. IN COMMENT }\end{array}$ & $\mathbf{P}$ & 00003 & M81403 & & - NOT ASSIGNED - * ADENOCARCINOMA & \\
\hline TXAO & $\begin{array}{l}\text { ADENOMA RARE TISS, WITH TUMOR SITE SPEC. } \\
\text { IN COMMENT }\end{array}$ & P & 00003 & M81400 & & - NOT ASSIGNED - * ADENOMA & \\
\hline TXEC & $\begin{array}{l}\text { SQDAMOUS CELI CARCINOMA RARE TISS. WITE } \\
\text { TUMOR; SITE SPEC. I. }\end{array}$ & 2 & 00003 & M80703 & & $\begin{array}{l}\text { - NOT ASSIGRED - * SQUAMOUS } \\
\text { CARCINOMA }\end{array}$ & \\
\hline TXFA & $\begin{array}{l}\text { FIBROADENOMA; RARE TISSUE WITH TUMOR; } \\
\text { SITE SPECIFIED IN COMI }\end{array}$ & $\mathbf{P}$ & 00003 & M90100 & & - NOT ASSIGNED - * FIBROADENOMA & \\
\hline TXFS & $\begin{array}{l}\text { EIBROSARCOMA RARE TISS. SITE SRECIFIED } \\
\text { IN COMMENT }\end{array}$ & $\mathbf{P}$ & 00003 & M88103 & & - NOT ASSIGNED - * EIBROSARCOMA & \\
\hline TXus & $\begin{array}{l}\text { LEIOMYOSARCOMA RARE TISSUE SITE } \\
\text { SPECIFIED IN COMMENT }\end{array}$ & $\mathbf{P}$ & 00003 & M88903 & & - NOT ASSIGNED - * LEIOMYOSARCOMA & \\
\hline TXOO & $\begin{array}{l}\text { ALI TNFO CODED IN COMMENT; UNIDENT. } \\
\text { TUMOR SIME SPEC. IN COMM }\end{array}$ & $\mathbf{P}$ & 00003 & M80001 & & - NOT ASSIGNED - * NEOPLASM & \\
\hline TXUS & $\begin{array}{l}\text { ONDIFFERENTIATED SARCOMA RARE TISSUE } \\
\text { SITE SPEC. IN COMMENT }\end{array}$ & $\mathbf{P}$ & 00003 & M88053 & & $\begin{array}{l}\text { - NOT ASSIGNED - * ONDIEFERENTIATED } \\
\text { SARCOMA }\end{array}$ & \\
\hline TXVS & $\begin{array}{l}\text { HEMANGIOENDO. (ANGIOSARCOMA), MALIG RARE } \\
\text { TISS SITE SPEC IN C }\end{array}$ & $\mathbf{P}$ & 00003 & M91203 & & - NOT ASSIGNED - * ANGIOSARCOMA & \\
\hline TXWB & $\begin{array}{l}\text { BONE ORIGIN IN COMM.; RARE TISS. MET. } \\
\text { SITE SPEC. IN COMM. }\end{array}$ & $\mathbf{s}$ & 00003 & & $1 \times 500$ & - NOT ASSIGNED - * & BONE \\
\hline TXWC & $\begin{array}{l}\text { CONNECTIVE TISSUE ORIGIN IN COMM.;RARE } \\
\text { TISS. MET. SITE SPEC. }\end{array}$ & $\mathbf{s}$ & 00003 & & $1 \times 200$ & - NOT ASSIGNED - * & CONNECTIVE TISSUE \\
\hline TXWG & $\begin{array}{l}\text { HARDERIAN GLAND ORIGIN; RARE TISS. MET. } \\
\text { SITE SPBC. IN COMM. }\end{array}$ & $\mathbf{s}$ & 00003 & & $8 \times 836$ & - NOT ASSIGNED - * & BARDERIAN GLAND \\
\hline TXWI & $\begin{array}{l}\text { GI TRACT ORIGIN IN COMM.; RARE TISS. } \\
\text { MET. SITE SPEC. IN COM. }\end{array}$ & $\mathbf{s}$ & 00003 & & 50100 & - NOT ASSIGNED - * & GI TRACT \\
\hline
\end{tabular}




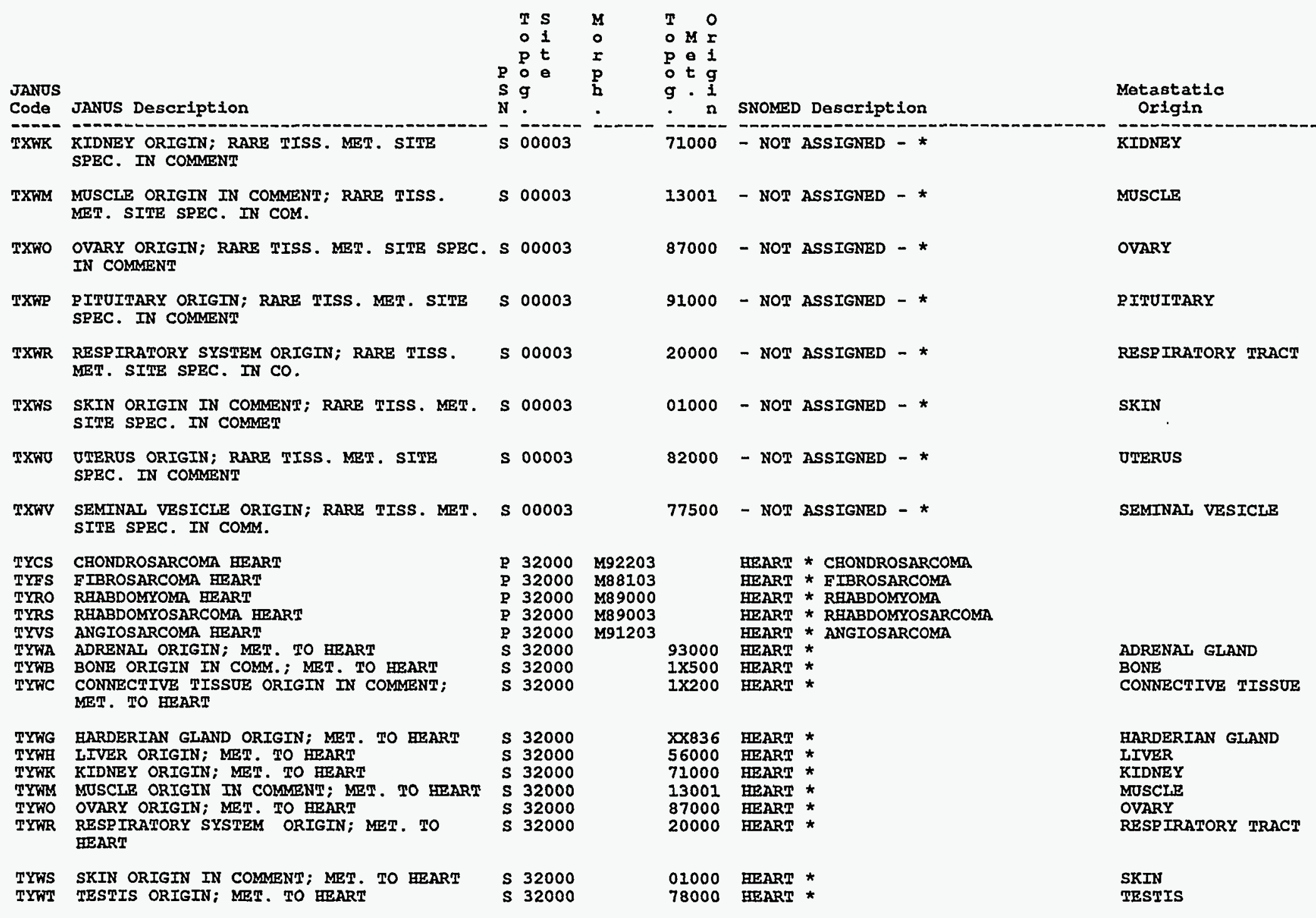




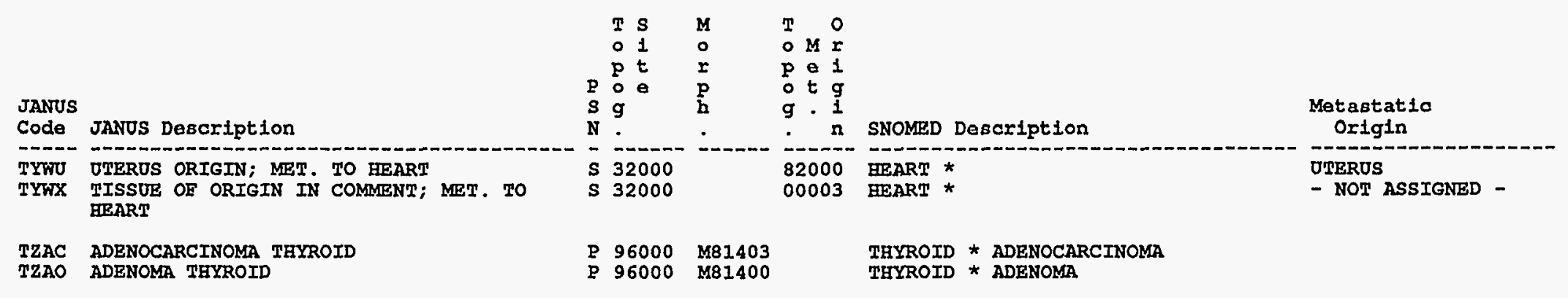

430 rows selected. 
APPENDIX I:

JANUS ORACLE TABLES 
JANUS ORACLE TABLES

\begin{abstract}
GENERAL
HISTORY

EXIT

FRACTIONS

MACBASE

MACEIND

MICBASE

MICFIND

NEXT NUMID

ROOMDEE

ROOMOCC

FILE_SEQNOS

The tables described in this appendix contain all the information necessary to initiate new experiments, to enter experimental data, or to be used in data analysis. The first eight tables contain all of the data for the experiments. The tables are arranged in the order in which the data are obtained. Table GENERAL and the last four tables contain all the information necessary to initiate experiments.

For each table described, the table headings and a sample line from the actual table are shown. Variable names in the headings are sometimes truncated to the number of spaces available for the data. The first line of each "Table Columns Description" gives the variable name (e.g., "EXPT"), the type and number of column positions, and a note if the variable must be present in the table ("NOT NULL"); this line is followed by an explanation of the variable.
\end{abstract}


Table GENERAL

This table contains the identification of a cage of mice and assigns the NUMID that is used to relate all the Tables.

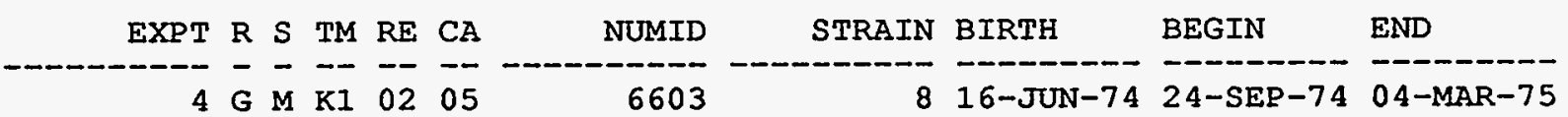

Table Columns Description

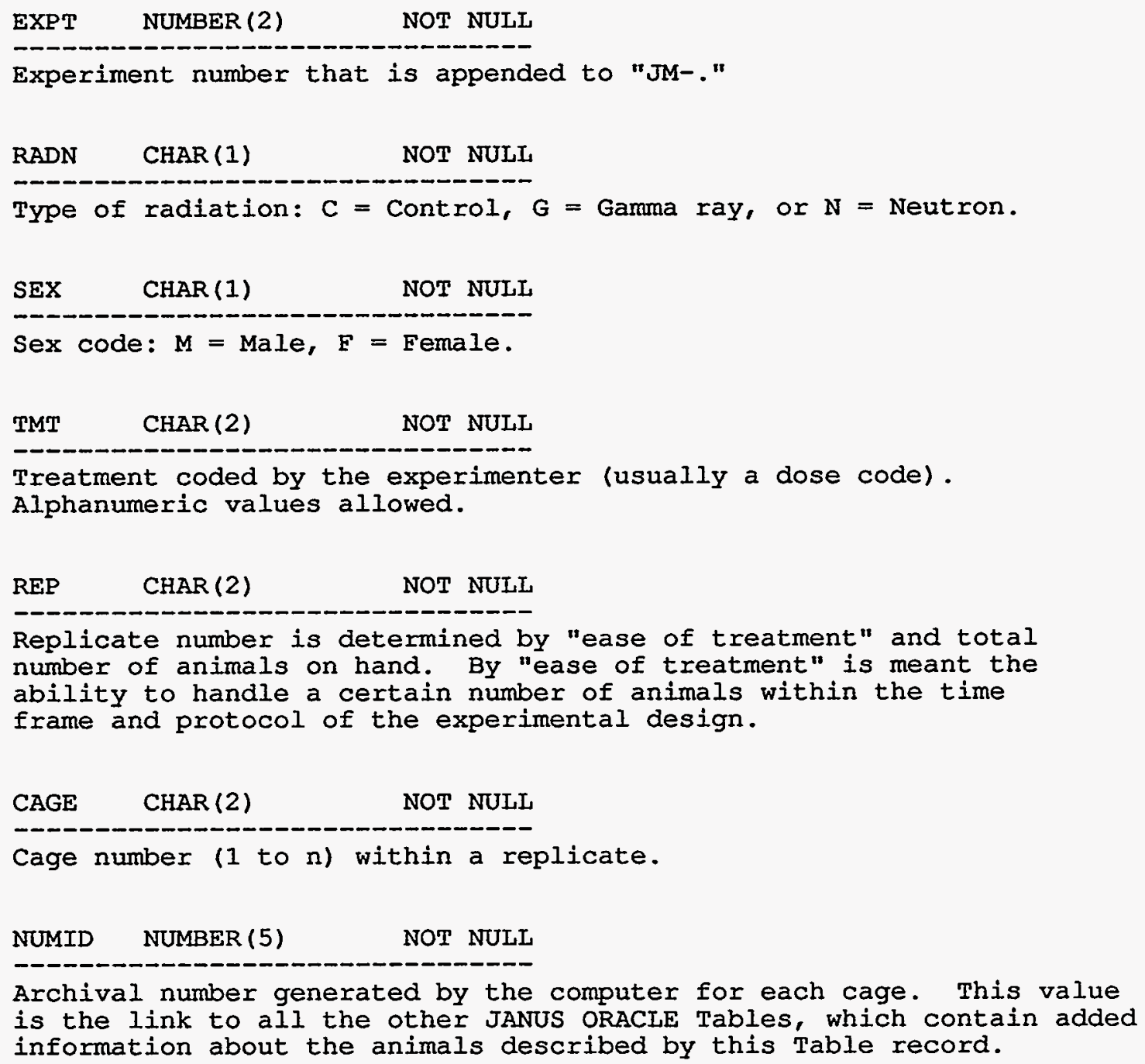


Table GENERAL (continued)

STRAIN NUMBER(2) NOT NULI

Animal strain code. In most $\mathrm{JM}$ experiments this is strain 08 , the B6CF1 mouse. In JM-10, Peromyscus leucopus was used and is designated strain 83 .

BIRTH DATE

Date of birth of the animals using a "weekly date."

BEGIN DATE

(1)

Date of first irradiation.

END DATE

Date of last irradiation. 
Table HISTORY

This table contains information about the location of a cage in the room and the number of animals in the cage; it also records the sequence of events for the cage. Several sample lines are shown for this table to show the progression of the data.

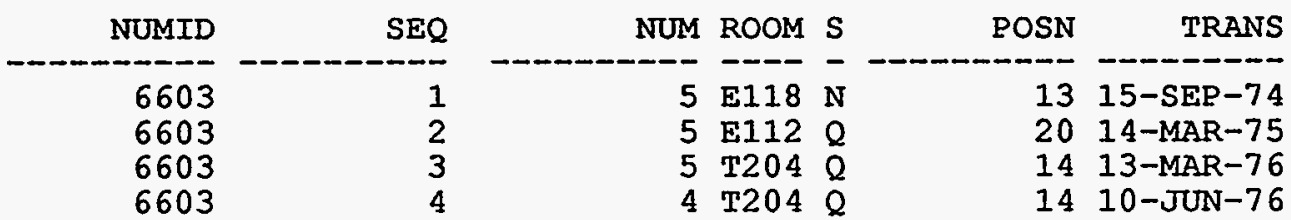

Table Columns Description

NUMID NUMBER (5) NOT NULI

Originates in Table GENERAI and is the archival number generated by the computer for each cage in the system. NUMID is the link to all other records in the system of ORACLE tables for a specific cage.

SEQ NUMBER (2) NOT NULL

Sequence number (range of 1 to $n$ ). Each time a HISTORY record with the same NUMID is created, the sequence number is incremented by one. All previous HISTORY records are maintained in the database. This gives an ordered trail of cage movement.

NUM NUMBER (1) NOT NULI

Number of animals in the cage. This number will decrease as animals are exited.

ROOM CHAR (4) NOT NULL

Room number (alphanumeric).

SHELE CHAR(1) NOT NULI

Shelf letter (range $A$ to $Z$ ).

POSN NUMBER(2) NOT NULI

Position number on the shelf (range 1 to 21 ).

TRANS DATE

Transaction date. Date on which the cage first occupied the above ROOM-SHELF-POSN or the date on which the number of animals in the cage decreased. 
Table EXIT

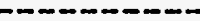

This table contains the information from the JANUS Death Tag (see Appendix A), which is filled out at the death of the mouse or its removal from the experiment.

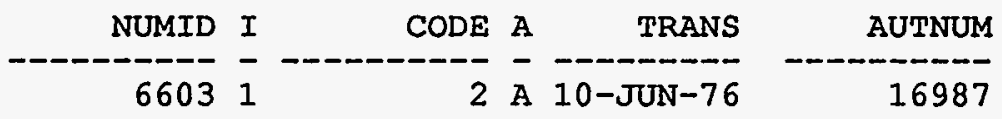

Table Columns Description

NUMID NUMBER (5) NOT NULL

NUMID originates in Table GENERAL and is the archival number generated by the computer for each cage in the system. NUMID is the link to all other records in the system of ORACLE tables for a specific cage.

INDIV CHAR(1) NOT NULL

Individual animal in the cage ranging from 1 to 5 . Number 1 is the first recorded and number 5 is the last. The animals are not preidentified; numbering is based on the order of death.

CODE NUMBER $(3,1) \quad$ NOT NULI

Exit code (see Appendix B) assigned by prosector at the time of necropsy.

AUTOP CHAR(1) NOT NULL

Autopsy code (see Appendix B) assigned by the prosector at the time of necropsy.

TRANS DATE NOT NULI

Date of death or removal from cage.

AUTNUM NUMBER (7)

Autopsy number is obtained from the number on the JANUS Death Tag (see Appendix A). 


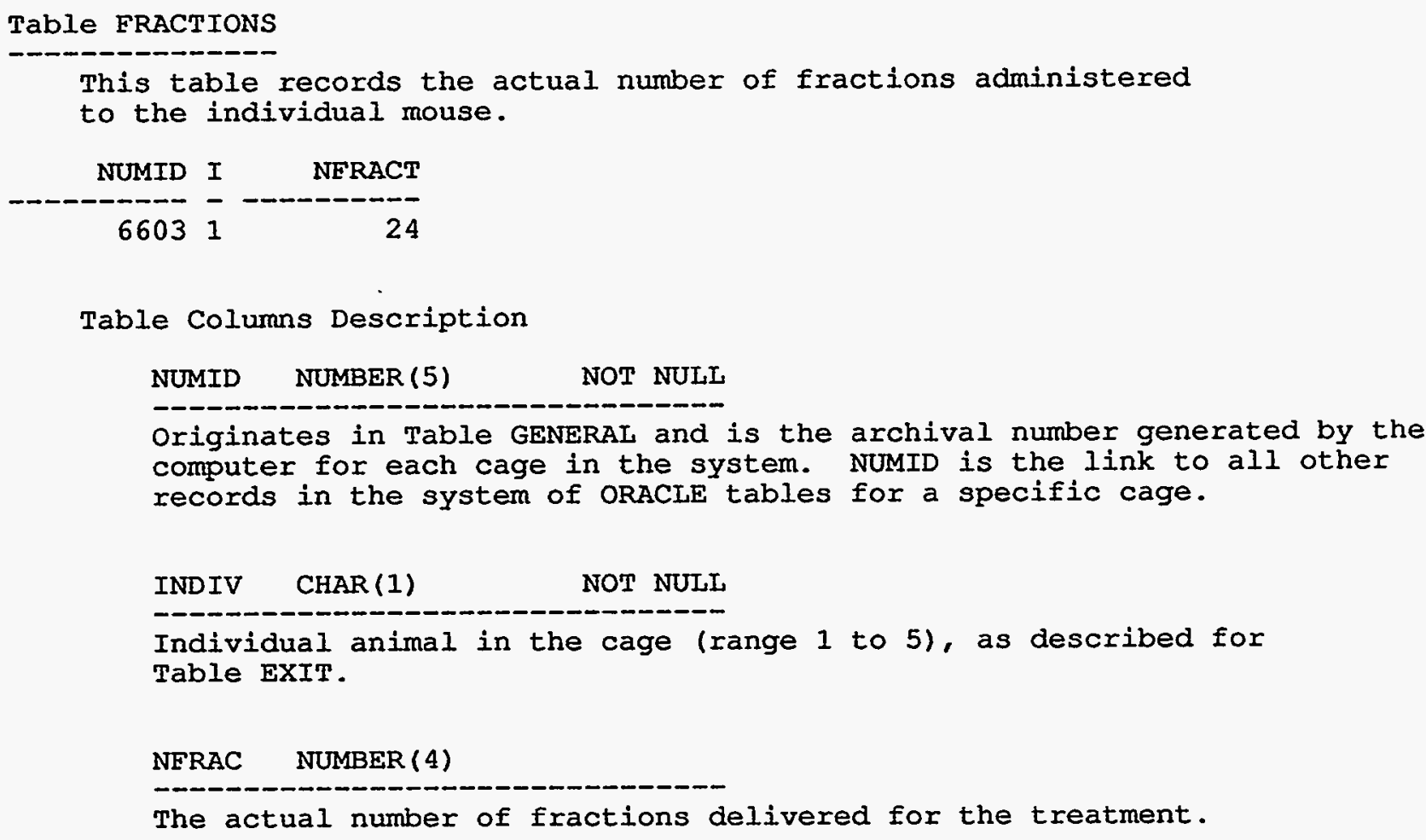




\title{
Table MACBASE
}

\author{
This table contains the individual identification information found on the \\ first and the carbon second page of the necropsy report (see Appendix C).

\begin{tabular}{llllll} 
NUMID & I & TRANS & PR TNUM & T \\
\hdashline 6603 & 1 & $10-J U N-76$ & KA & C00735 & T
\end{tabular} \\ Table Columns Description \\ NUMID NUMBER (5) NOT NULL \\ Originates in Table GENERAI and is the archival number generated by the \\ computer for each cage in the systern. NUMID is the link to all other \\ records in the system of ORACLE tables for a specific cage. \\ INDIV CHAR(1) NOT NULL \\ Individual animal in the cage (range 1 to 5), as described for \\ Table EXIT. \\ TRANS DATE NOT NULI \\ Date of necropsy. \\ PRO CHAR(2) NOT NULL \\ Two initials of the prosector. \\ TNUM CHAR(6) \\ Tissue number (alphanumeric as a letter assigned to a particular \\ JM experiment and a sequential number obtained at the time of necropsy; \\ e.g., JM-13 tissue numbers are s00001 to Snnnnn). \\ TUMOR CHAR(1) \\ Presence of a tumor designated by the letter "T"; absence of a \\ tumor designated by the letter "N."
}


Table MACEIND

This table contains the MACRO diagnoses coded at the time of the necropsy.

The COMMENT column is on a separate line because of the number of char-

acters allowed for a comment; this column may be null.

NUMID I I CODE TOPO MORPH

\section{CMT}

66031 N NTYG 00020 MYY933

Table Column Description

NUMID NUMBER(5) NOT NULL

Originates in Table GENERAL and is the archival number generated by the computer for each cage in the system. NUMID is the link to all other records in the system of ORACLE tables for a specific cage.

INDIV CHAR(1) NOT NULI

Individual animal in the cage (range 1 to 5), as described for Table EXIT.

ITH CHAR(1) NOT NULL

A letter " $L$ " is in this field if the MACFIND.CODE is the cause of death (lethal) as determined by the prosector; a letter " $N$ " if nonlethal.

CODE CHAR (4) NOT NULI

Four-letter JANUS mouse tumor MACRO code or three-letter JANUS mouse nontumor MACRO code assigned by prosector.

TOPO CHAR (5)

Topography of lesion; five-character SNOMED code (numeric). The SNOMED code is entered by the computer when the letter code for the lesion is entered.

MORPH $\operatorname{CHAR}(6)$

Morphology of lesion; six-character SNOMED code (alphanumeric). The SNOMED code is entered by the computer when the letter code for the lesion is entered.

CMT CHAR (240)

Comment; contains additional information regarding the lesion. 
Table MICBÁSE

\section{Table MICBASE}

This table contains the individual identification information found on the third page of the necropsy report (see Appendix C).

NUMID I TRANS PR T

$6603123-A U G-79$ II T

Table Columns Description

NUMID NUMBER (5) NOT NULI

Originates in Table GENERAL and is the archival number generated by the computer for each cage in the system. NUMID is the link to all other records in the system of ORACLE tables for a specific cage.

INDIV CHAR(1) NOT NULL

Individual animal in the cage (range 1 to 5), as described for Table EXIT.

TRANS DATE NOT NULL

Date slides were read or pathologist's report was dated; official closing date.

PRO CHAR (2) NOT NULL

Two initials of the pathologist who read the slides.

TDEATH CHAR(1) NOT NULI

Letter "T" designates that the cause of death was a tumor; letter "N" designates a that the cause of death was a nontumor. 
Table MICFIND

This table contains the histopathological diagnoses coded on the third page of the necropsy report (see Appendix $C$ ). The COMMENT and METORIG columns are on separate lines because of the number of characters allowed for the COMMENT; these columns may be null.

NUMID I I CODE TOPO MORPH H

\section{CMT}

METOR

(n)

66031 L TLLS 05000 M96993 H

Table Columns Description

NUMID NUMBER (5) NOT NULL

Originates in Table GENERAI and is the archival number generated by the computer for each cage in the system. NUMID is the link to all other records in the system of ORACLE tables for a specific cage.

INDIV CHAR(1) NOT NULL

Individual animal in the cage (range 1 to 5), as described for Table EXIT.

ITH CHAR (1)

Code indicating lethality of the lesion:

I $\quad$ Lethal

C Contributory

N Noncontributory

Blank For missing part codes used in MICRO findings

CODE CHAR (4) NOT NULL

Four-letter JANUS mouse MICRO code assigned by pathologist.

TOPO CHAR (5)

Topography of lesion; five-character SNOMED code (numeric). The code is entered by the computer when the letter code for the lesion is entered.

MORPH CHAR (6)

Morphology of lesion; six-character SNOMED code (alphanumeric). The code is entered by the computer when the letter code

for the lesion is entered.

HIST CHAR (1)

Letter " $\mathrm{H}$ " if a histological examination of tissue was done. 


\section{$I-13$}

Table MICFIND (continued)

CMT CHAR (240)

Comment; additional information regarding the lesion.

METORIG CHAR (5)

Topography of the metastatic origin; five-character SNOMED code (numeric). The code is entered by the computer when the letter code for the metastatic lesion is entered. 
Table NEXT_NUMID

This table contains the sequential numbers assigned to GENERAL. NUMID.

NUMVAL

16000

Table Colums Description

NUMVAL NUMBER(5)

Number assigned to GENERAI. NUMID when a new cage of animals enters the database system. This number is incremented by one with each new cage. 
Table ROOMDEF

This table describes the animal rooms.
ROOM S B E
E129 L A G

Table Columns Description

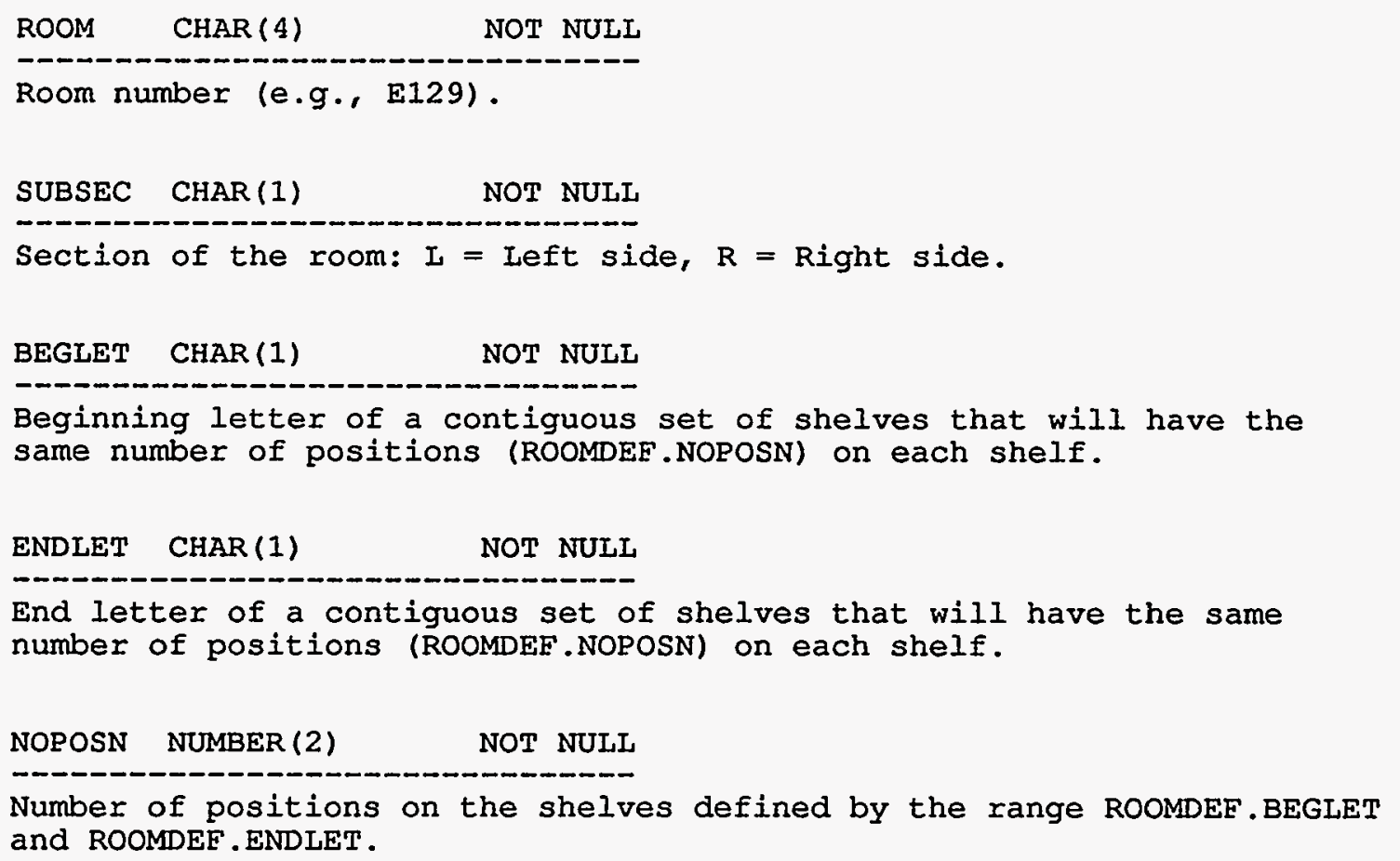


Table ROOMOCC

This table contains the identification of the animals located in certain positions in the animal rooms. This table only contains records when experiments are being conducted and as long as a cage occupies the space; there are no experiments in progress at this time.

NUMID $\quad$ SEQ $\quad$ NUM ROOM S POSN TRANS R

No rows selected

Table Column Description

NUMID NUMBER (5) NOT NULL

Originates in Table GENERAI and is the archival number generated by the computer for each cage in the system. NUMID is the link to all other records in the system of ORACLE tables for a specific cage.

SEQ NUMBER(2) NOT NULL

Sequence number (range of 1 to $n$ ). Each time a HISTORY record with the same NUMID is created, the sequence number is incremented by one. All previous HISTORY records are maintained in the database. This gives an ordered trail of cage movement.

NUM NUMBER(1) NOT NULL

Number of animals in the cage.

ROOM CHAR (4) NOT NULL

Room number (e.g., E129).

SHELF CHAR(1) NOT NULL

Shelf letter (range A to $z$ ).

POSN NUMBER(2) NOT NULL

Position number on the shelf.

TRANS DATE

Transaction date. This date first signifies when the cage occupies the above ROOM-SHELF-POSN and later is modified as each animal exits the cage.

RELOC CHAR (1)

Flag to indicate whether the cage is in the process of being relocated. If RELOC contains the letter " $R$," then the cage is under relocation; otherwise, RELOC will be null. 
Table FILE_SEQNOS

This table contains information used in setting up new experiments and the room assignments for these animals.

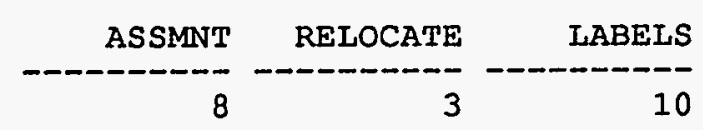

Table Columns Description

ASSMNT NUMBER (5)

Sequence number ASSMNT is used to identify a particular assignment file created by program JNRMMNG (JANUS ANIMAI ROOM MANAGEMENT). The file is called JNRMMNG ASSIGN $\mathrm{x} \times \mathrm{xxx}$.OUT, where $\mathrm{xx \times xx}$ is the ASSMNT value. ASSMNT is incremented accordingly by program JNRMMNG.

RELOCATE NUMBER(5)

Sequence number RELOCATE is used to identify a particular relocation file created by program JNRMMNG (JANUS ANIMAL ROOM MANAGEMENT). The file is called JNRMMNG RELOCATE YYYYY.OUT, where YYYYY is the RELOCATE value. RELOCATE is incremented accordingly by program JNRMMNG.

LABELS NUMBER (5)

Sequence number LABELS is used to identify a particular labels file created by program JNRMMNG (JANUS ANIMAL ROOM MANAGEMENT). The file is called JNRMMNG_LABELS_zzzzz.OUT, where zzzzz is the LABEL value. LABEL is incremente $\bar{d}$ accordingly by program JNRMMNG. 
I-18 
APPENDIX J:

JANUS RADIATION PROTOCOL 
APPENDIX J:

JANUS RADIATION PROTOCOL

\begin{tabular}{|c|c|c|c|c|c|c|c|c|}
\hline $\begin{array}{l}\text { Expt. } \\
\text { No. } \\
\text { (JM-) }\end{array}$ & $\begin{array}{l}\text { Treat- } \\
\text { ment } \\
\text { Code }\end{array}$ & $\begin{array}{l}\text { Radia- } \\
\text { tion } \\
\text { Quality }^{\mathrm{a}}\end{array}$ & $\begin{array}{c}c G y \\
\text { (total) }\end{array}$ & $\begin{array}{l}\text { Time } \\
\text { (min) }\end{array}$ & $\begin{array}{l}\text { Frac- } \\
\text { tions }\end{array}$ & $\begin{array}{c}\text { Fraction/ } \\
\text { Unit } \\
\text { Time }\end{array}$ & $\begin{array}{c}\text { No. of } \\
\text { Repeats }\end{array}$ & Comments \\
\hline 2 & $\mathrm{AC}$ & C & 0 & 15 & 72 & $3 / w$ & & \\
\hline 2 & $\mathrm{DC}$ & $\mathrm{C}$ & 0 & 45 & 24 & $1 / w$ & & \\
\hline 2 & EC & $\mathrm{C}$ & 0 & 360 & 24 & $1 / w$ & & \\
\hline 2 & $\mathrm{HC}$ & $\mathrm{C}$ & 0 & 180 & 6 & $1 / \mathrm{m}$ & & \\
\hline 2 & So & $\mathrm{C}$ & 0 & 20 & 1 & & & \\
\hline 2 & AI & $\mathbf{G}$ & 855 & 15 & 72 & $3 / w$ & & \\
\hline 2 & $\mathrm{BI}$ & $\mathbf{G}$ & 855 & 45 & 24 & $1 / \mathrm{w}$ & & \\
\hline 2 & DI & $G$ & 1110 & 45 & 24 & $1 / w$ & & \\
\hline 2 & EI & $\mathbf{G}$ & 855 & 360 & 24 & $1 / w$ & & \\
\hline 2 & $\mathrm{HI}$ & $\mathbf{G}$ & 855 & 180 & 6 & $1 / \mathrm{m}$ & & \\
\hline 2 & S1 & $\mathbf{G}$ & 90 & 20 & 1 & & & \\
\hline 2 & S2 & $G$ & 268 & 20 & 1 & & & \\
\hline 2 & S3 & $\bar{G}$ & 788 & 20 & 1 & & & \\
\hline 2 & Y2 & G & 268 & 20 & 1 & & & Age $194 \mathrm{~d}$ \\
\hline 2 & Y3 & $\mathbf{G}$ & 788 & 20 & 1 & & & Age $194 \mathrm{~d}$ \\
\hline 2 & $\mathbf{Z 2}$ & G & 268 & 20 & 1 & & & Age $287 \mathrm{~d}$ \\
\hline 2 & $\mathbf{Z 3}$ & G & 788 & 20 & 1 & & & Age $287 \mathrm{~d}$ \\
\hline 2 & $\mathrm{AI}$ & $\mathbf{N}$ & 240 & 15 & 72 & $3 / w$ & & \\
\hline 2 & BI & $\mathbf{N}$ & 240 & 45 & 24 & $1 / w$ & & \\
\hline 2 & $\mathrm{DI}$ & $\mathrm{N}$ & 80 & 45 & 24 & $1 / w$ & & \\
\hline 2 & EI & $\mathbf{N}$ & 240 & 360 & 24 & $1 / w$ & & \\
\hline 2 & HII & $\mathrm{N}$ & 240 & 180 & 6 & $1 / m$ & & \\
\hline 2 & S1 & $\mathrm{N}$ & 20 & 20 & 1 & & & \\
\hline 2 & S2 & $\mathrm{N}$ & 80 & 20 & 1 & & & \\
\hline 2 & S3 & $\mathrm{N}$ & 240 & 20 & 1 & & & \\
\hline 2 & Y2 & $\mathrm{N}$ & 80 & 20 & 1 & & & Age $194 \mathrm{~d}$ \\
\hline 2 & Y3 & $\mathbf{N}$ & 240 & 20 & 1 & & & Age $194 \mathrm{~d}$ \\
\hline 2 & $\mathbf{Z 2}$ & $\mathrm{N}$ & 80 & 20 & 1 & & & Age $287 \mathrm{~d}$ \\
\hline 2 & Z3 & $\mathrm{N}$ & 240 & 20 & 1 & & & Age $287 \mathrm{~d}$ \\
\hline 3 & So & C & 0 & 20 & 1 & & & \\
\hline $\mathbf{3}$ & S4 & $\mathbf{G}$ & 90 & 20 & 1 & & & \\
\hline 3 & S5 & $\mathbf{G}$ & 143 & 20 & 1 & & & Females discarded \\
\hline 3 & S6 & $\bar{G}$ & 206 & 20 & 1 & & & Females discarded \\
\hline 3 & S7 & $\vec{G}$ & 417 & 20 & $\overrightarrow{1}$ & & & \\
\hline 3 & S8 & $\mathbf{G}$ & 569 & 20 & 1 & & & Some females discarded \\
\hline $\mathbf{3}$ & $\mathrm{S} 4$ & $\mathbf{N}$ & 20 & 20 & 1 & & & \\
\hline 3 & S5 & $\mathbf{N}$ & 40 & 20 & 1 & & & Females discarded \\
\hline 3 & S6 & $\mathbf{N}$ & 60 & 20 & 1 & & & Females discarded \\
\hline 3 & S7 & $\mathbf{N}$ & 120 & 20 & 1 & & & Females discarded \\
\hline 3 & S8 & $\mathbf{N}$ & 160 & 20 & 1 & & & \\
\hline 3 & SL & $\mathbf{N}$ & 240 & 480 & 1 & & & Males; no MICROS \\
\hline 3 & SH & $\mathbf{N}$ & 240 & 20 & 1 & & & Males; no MICROS \\
\hline 4 & KO & C & 0 & 45 & 24 & $1 / \mathbf{w}$ & & \\
\hline 4 & $\mathrm{~K} 1$ & G & 206 & 45 & 24 & $1 / w$ & & Females reassigned \\
\hline 4 & $\mathrm{~K} 2$ & $G$ & 417 & 45 & 24 & $1 / w$ & & \\
\hline 4 & K3 & $\mathbf{G}$ & 959 & 45 & 24 & $1 / w$ & & Females reassigned \\
\hline 4 & $\mathrm{~K} 4$ & $\mathbf{G}$ & 1919 & 45 & 24 & $1 / w$ & & Most females reassigned \\
\hline 4 & $\mathrm{~K} 5$ & $\mathbf{G}$ & 3820 & 45 & 24 & $1 / w$ & & $\begin{array}{l}\text { Males \& a few females; } \\
\text { no MICROS }\end{array}$ \\
\hline 4 & K6 & $\mathbf{G}$ & 5111 & 45 & 24 & $1 / w$ & & No MICROS \\
\hline 4 & $\mathrm{~K} 1$ & $N$ & 20 & 45 & 24 & $1 / w$ & & \\
\hline 4 & $\mathrm{~K} 2$ & $\mathbf{N}$ & 40 & 45 & 24 & $1 / w$ & & Females reassigned \\
\hline
\end{tabular}




\begin{tabular}{|c|c|c|c|c|c|c|c|c|}
\hline $\begin{array}{l}\text { Expt. } \\
\text { No. } \\
\text { (JM-) }\end{array}$ & $\begin{array}{l}\text { Treat- } \\
\text { ment } \\
\text { Code }\end{array}$ & $\begin{array}{c}\text { Radia- } \\
\text { tion } \\
\text { Quality }^{\mathbf{a}}\end{array}$ & $\begin{array}{c}\text { cGy } \\
\text { (total) }\end{array}$ & $\begin{array}{l}\text { Time } \\
(\mathrm{min})\end{array}$ & $\begin{array}{l}\text { Frac- } \\
\text { tions }\end{array}$ & $\begin{array}{c}\text { Fraction/ } \\
\text { Unit } \\
\text { Time }^{b}\end{array}$ & $\begin{array}{c}\text { No. of } \\
\text { Repeats }\end{array}$ & Comments \\
\hline 4 & K3 & $\mathbf{N}$ & 60 & 45 & 24 & $1 / w$ & & Females reassigned \\
\hline 4 & $\mathrm{~K} 4$ & $\mathbf{N}$ & 120 & 45 & 24 & $1 / w$ & & Females reassigned \\
\hline 4 & K5 & $\mathbf{N}$ & 168 & 45 & 24 & $1 / w$ & & \\
\hline 4 & K6 & $\mathbf{N}$ & 320 & 45 & 24 & $1 / w$ & & Females reassigned \\
\hline 4 & Lo & C & 0 & 1320 & 5 & $5 / w$ & 23 & Males \\
\hline 4 & LC & C & 0 & 1320 & 5 & $5 / w$ & 59 & Males \\
\hline 4 & L1 & $\mathbf{G}$ & 206 & 1320 & 5 & $5 / \mathrm{w}$ & 23 & Males \\
\hline 4 & L2 & $\mathbf{G}$ & 417 & 1320 & 5 & $5 / \mathrm{w}$ & 23 & Males \\
\hline 4 & L3 & $\mathbf{G}$ & 959 & 1320 & 5 & $5 / w$ & 23 & Males \\
\hline 4 & L4 & $\vec{G}$ & 1918 & 1320 & 5 & $5 / w$ & 23 & Males \\
\hline 4 & L5 & $\mathbf{G}$ & 529 & 1320 & 5 & $5 / w$ & 59 & Males \\
\hline 4 & L6 & $\vec{G}$ & 1070 & 1320 & 5 & $5 / \mathrm{w}$ & 59 & Males \\
\hline 4 & L7 & $\mathbf{G}$ & 2460 & 1320 & 5 & $5 / w$ & 59 & Males \\
\hline 4 & W0 & C & 0 & 45 & 24 & $1 / w$ & & Females; no MICROS \\
\hline 4 & W1 & $\mathbf{G}$ & 807 & 45 & 24 & $1 / w$ & & Females; no MICROS \\
\hline 4 & W2 & $\mathbf{G}$ & 2690 & 45 & 24 & $1 / w$ & & Females; no MICROS \\
\hline 4 & W1 & $\mathbf{N}$ & 80 & 45 & 24 & $1 / w$ & & Females; no MICROS \\
\hline 4 & W2 & $\mathbf{N}$ & 240 & 45 & 24 & $1 / w$ & & Females; no MICROS \\
\hline 7 & 00 & C & 0 & 20 & 0 & & & \\
\hline 7 & Q1 & $\mathbf{G}$ & 417 & 45 & 60 & $1 / w$ & & MICROS of males only \\
\hline 7 & Q2 & $\mathbf{G}$ & 1918 & 45 & 60 & $1 / w$ & & MICROS of males only \\
\hline 7 & Q1 & $\mathbf{N}$ & 40 & 45 & 60 & $1 / w$ & & MICROS of males only \\
\hline 7 & Q2 & $\mathbf{N}$ & 160 & 45 & 60 & $1 / w$ & & MICROS of males only \\
\hline 7 & R1 & $\mathbf{G}$ & 206 & 20 & 1 & & & Age at start $515 \mathrm{~d}$ \\
\hline 7 & $\mathrm{R} 2$ & $\mathbf{G}$ & 569 & 20 & 1 & & & Age at start $515 \mathrm{~d}$ \\
\hline 7 & $\mathrm{R} 1$ & $\mathbf{N}$ & 40 & 20 & 1 & & & Age at start $515 \mathrm{~d}$ \\
\hline 7 & R2 & $\mathbf{N}$ & 160 & 20 & 1 & & & Age at start $515 \mathrm{~d}$ \\
\hline 8 & UO & $\mathrm{C}$ & 0 & 45 & 999 & $1 / w$ & & $\begin{array}{l}\text { MICROS of males and } \\
\text { females }\end{array}$ \\
\hline 8 & U1 & $\mathbf{G}$ & 6.95 & 45 & 999 & $1 / w$ & & MICROS of males only \\
\hline 8 & $\mathrm{U2}$ & $\mathbf{G}$ & 17.38 & 45 & 999 & $1 / \mathrm{w}$ & & MICROS of males only \\
\hline 8 & U3 & G & 31.9 & 45 & 999 & $1 / w$ & & $\begin{array}{l}\text { Males \& a few females; } \\
\text { no MICROS }\end{array}$ \\
\hline 8 & U1 & $\mathrm{N}$ & 0.667 & 45 & 999 & $1 / w$ & & $\begin{array}{l}\text { MICROS of males and } \\
\text { females }\end{array}$ \\
\hline 8 & U2 & $\mathbf{N}$ & 1.67 & 45 & 999 & $1 / w$ & & $\begin{array}{l}\text { Males \& a few females; } \\
\text { no MICROS }\end{array}$ \\
\hline 8 & U3 & $\mathbf{N}$ & 2.67 & 45 & 999 & $1 / w$ & & $\begin{array}{l}\text { Males \& a few females; } \\
\text { no MICROS }\end{array}$ \\
\hline 9 & $\mathrm{XC}$ & C & 0 & 20 & 1 & & & Females \\
\hline 9 & Xo & C & 0 & 45 & 1 & & & No MICROS \\
\hline 9 & $x X$ & C & 0 & 45 & 24 & $1 / w$ & & Females; no MICROS \\
\hline 9 & $\mathrm{X} 1$ & G & 22.5 & 20 & 1 & & & Females \\
\hline 9 & $\mathrm{X2}$ & $\mathbf{G}$ & 45 & 20 & 1 & & & Females \\
\hline 9 & $\mathrm{X3}$ & G & 90 & 20 & 1 & & & Females \\
\hline 9 & $\mathrm{XX}$ & $N$ & 10 & 45 & 24 & $1 / w$ & & Females; no MICROS \\
\hline 9 & $\mathrm{X} 2$ & $\mathbf{N}$ & 5 & 5 & 1 & & & Females; no MICROS \\
\hline 9 & $\mathrm{X3}$ & $\mathrm{N}$ & 10 & 10 & 1 & & & No MICROS \\
\hline 9 & $\mathrm{X} 4$ & $N$ & 1 & 20 & 1 & & & Females \\
\hline 9 & $\mathrm{X} 5$ & $\mathbf{N}$ & 2.5 & 20 & 1 & & & Females \\
\hline 9 & $\mathrm{X} 6$ & $\mathbf{N}$ & 5 & 20 & 1 & & & Females \\
\hline 9 & $\mathrm{X} 7$ & $\mathrm{~N}$ & 10 & 20 & 1 & & & Females \\
\hline 9 & X8 & $\mathrm{N}$ & 20 & 20 & 1 & & & Females \\
\hline 9 & $\mathrm{X} 9$ & $\mathrm{~N}$ & 40 & 20 & 1 & & & Females \\
\hline 10 & Vo & $\mathrm{C}$ & 0 & 45 & 24 & $1 / \mathbf{w}$ & & $\begin{array}{l}P . \text { leucopus males; } \\
\text { no MICROS }\end{array}$ \\
\hline
\end{tabular}




\begin{tabular}{|c|c|c|c|c|c|c|c|c|}
\hline $\begin{array}{l}\text { Expt. } \\
\text { No. } \\
\text { (JM-) }\end{array}$ & $\begin{array}{l}\text { Treat- } \\
\text { ment } \\
\text { Code }\end{array}$ & $\begin{array}{l}\text { Radia- } \\
\text { tion } \\
\text { Quality }^{a}\end{array}$ & $\begin{array}{c}\text { cGy } \\
\text { (total) }\end{array}$ & $\begin{array}{l}\text { Time } \\
\text { (min) }\end{array}$ & $\begin{array}{l}\text { Frac- } \\
\text { tions }\end{array}$ & $\begin{array}{c}\text { Fraction/ } \\
\text { Unit } \\
\text { Time }^{b}\end{array}$ & $\begin{array}{l}\text { No. of } \\
\text { Repeats }\end{array}$ & Comments \\
\hline 10 & wo & $\mathrm{C}$ & 0 & 20 & 1 & & & $\begin{array}{l}P . \text { leucopus males; } \\
\text { no MICROS }\end{array}$ \\
\hline 10 & V1 & G & 90 & 20 & 1 & & & $\begin{array}{l}P . \text { leucopus males; } \\
\text { no MICROS }\end{array}$ \\
\hline 10 & V2 & $\mathbf{G}$ & 143 & 20 & 1 & & & $\begin{array}{l}P . \text { leucopus males; } \\
\text { no MICROS }\end{array}$ \\
\hline 10 & V3 & G & 206 & 20 & 1 & & & $\begin{array}{l}P . \text { leucopus males; } \\
\text { no MICROS }\end{array}$ \\
\hline 10 & V4 & G & 417 & 20 & 1 & & & $\begin{array}{l}P . \text { leucopus males; } \\
\text { no MICROS }\end{array}$ \\
\hline 10 & VV & $\mathrm{N}$ & 40 & 45 & 24 & $1 / w$ & & $\begin{array}{l}P . \text { leucopus males; } \\
\text { no MICROS }\end{array}$ \\
\hline 10 & V1 & $\mathbf{N}$ & 20 & 20 & 1 & & & $\begin{array}{l}P . \text { leucopus males; } \\
\text { no MICROS }\end{array}$ \\
\hline 10 & V2 & $\mathbf{N}$ & 40 & 20 & 1 & & & $\begin{array}{l}P . \text { leucopus males; } \\
\text { no MICROS }\end{array}$ \\
\hline 10 & V3 & $\mathbf{N}$ & 80 & 20 & 1 & & & $\begin{array}{l}\text { P. leucopus males; } \\
\text { no MICROS }\end{array}$ \\
\hline 10 & V4 & $\mathbf{N}$ & 160 & 20 & 1 & & & $\begin{array}{l}P . \text { leucopus males; } \\
\text { no MICROS }\end{array}$ \\
\hline 10 & VW & $\mathbf{N}$ & 160 & 45 & 24 & $1 / w$ & & $\begin{array}{l}P . \text { leucopus males; } \\
\text { no MTCROS }\end{array}$ \\
\hline 12 & Jo & C & 0 & & $\mathbf{0}$ & & & Males; no MICROS \\
\hline 12 & JI & $\mathbf{N}$ & 240 & 20 & 1 & $1 / \mathbf{w}$ & & Males; no MICROS \\
\hline 12 & J2 & $\mathbf{N}$ & 240 & 20 & 2 & $1 / w$ & & Males; no MICROS \\
\hline 12 & J4 & $\mathbf{N}$ & 240 & 20 & 4 & $1 / w$ & & Males; no MICROS \\
\hline 12 & J6 & $\mathrm{N}$ & 240 & 20 & 6 & $1 / w$ & & Males; no MICROS \\
\hline 13 & $\mathbf{O A}$ & C & 0 & 20 & 60 & $1 / w$ & & \\
\hline 13 & OB & C & 0 & 20 & 60 & $1 / w$ & & \\
\hline 13 & $\mathrm{OC}$ & $\mathbf{C}$ & 0 & 20 & 60 & $1 / w$ & & \\
\hline 13 & $0 \mathrm{X}^{\mathrm{c}}$ & C & 0 & 20 & 60 & $1 / w$ & & \\
\hline 13 & $1 \mathrm{~A}$ & $\mathbf{G}$ & 100 & 20 & 60 & $1 / w$ & & \\
\hline 13 & $1 B$ & $\mathbf{G}$ & 100 & 20 & 60 & $1 / w$ & & \\
\hline 13 & $1 \mathrm{C}$ & $\mathbf{G}$ & 100 & 20 & 60 & $1 / w$ & & \\
\hline 13 & $1 \mathrm{X}^{\mathrm{c}}$ & $\mathbf{G}$ & 100 & 20 & 60 & $1 / w$ & & \\
\hline 13 & $2 \mathrm{~A}$ & G & 200 & 20 & 60 & $1 / w$ & & \\
\hline 13 & $2 \mathrm{X}^{\mathrm{c}}$ & $\mathbf{G}$ & 200 & 20 & 60 & $\mathbf{1}_{\mathbf{w}}$ & & \\
\hline 13 & 3A & $\mathbf{G}$ & 300 & 20 & 60 & $1 / \mathrm{w}$ & & \\
\hline 13 & $3 X^{c}$ & $\vec{G}$ & 300 & 20 & 60 & $1 / w$ & & \\
\hline 13 & $4 \mathrm{~A}$ & $\mathbf{G}$ & 450 & 20 & 60 & $1 / w$ & & \\
\hline 13 & $4 X^{c}$ & G & 450 & 20 & 60 & $1 / w$ & & \\
\hline 13 & $5 \mathrm{~A}$ & $\mathbf{G}$ & 600 & 20 & 60 & $1 / w$ & & \\
\hline 13 & $5 \mathrm{X}^{\mathrm{c}}$ & $\mathbf{G}$ & 600 & 20 & 60 & $1 / w$ & & \\
\hline 13 & IA & $\mathbf{N}$ & 2 & 20 & 60 & $1 / w$ & & \\
\hline 13 & 1B & $\mathbf{N}$ & 2 & 20 & 60 & $1 / w$ & & \\
\hline 13 & $1 \mathrm{C}$ & $\mathrm{N}$ & 2 & 20 & 60 & $1 / w$ & & \\
\hline 13 & $1 \mathrm{X}^{\mathrm{c}}$ & $\mathbf{N}$ & 2 & 20 & 60 & $1 / w$ & & \\
\hline 13 & $2 \mathrm{~A}$ & $\mathbf{N}$ & 7.5 & 20 & 60 & $1 / w$ & & \\
\hline 13 & $2 X^{c}$ & $\mathbf{N}$ & 7.5 & 20 & 60 & $1 / w$ & & \\
\hline 13 & $3 \mathrm{~A}$ & $\mathbf{N}$ & 13.5 & 20 & 60 & $1 / w$ & & \\
\hline 13 & $3 X^{c}$ & $\mathrm{~N}$ & 13.5 & 20 & 60 & $1 / w$ & & \\
\hline 13 & $4 \mathrm{~A}$ & $\mathbf{N}$ & 21 & 20 & 60 & $1 / w$ & & \\
\hline 13 & $4 X^{\mathrm{c}}$ & $N$ & 21 & 20 & 60 & $1 / w$ & & \\
\hline 13 & $5 \mathrm{~A}$ & $\mathrm{~N}$ & 30 & 20 & 60 & $1 / w$ & & \\
\hline 13 & $5 X^{c}$ & $\mathbf{N}$ & 30 & 20 & 60 & $1 / w$ & & \\
\hline 13 & $6 \mathrm{~A}$ & $\mathbf{N}$ & 40 & 20 & 60 & $y_{w}$ & & \\
\hline 13 & $6 X^{c}$ & $\mathrm{~N}$ & 40 & 20 & 60 & $1 / w$ & & \\
\hline
\end{tabular}




\begin{tabular}{|c|c|c|c|c|c|c|c|c|}
\hline $\begin{array}{l}\text { Expt. } \\
\text { No. } \\
\text { (JM-) }\end{array}$ & $\begin{array}{l}\text { Treat- } \\
\text { ment } \\
\text { Code }\end{array}$ & $\begin{array}{c}\text { Radia- } \\
\text { tion } \\
\text { Quality }^{\mathbf{a}}\end{array}$ & $\begin{array}{c}\text { cGy } \\
\text { (total) }\end{array}$ & $\begin{array}{l}\text { Time } \\
\text { (min) }\end{array}$ & $\begin{array}{l}\text { Frac- } \\
\text { tions }\end{array}$ & $\begin{array}{c}\text { Fraction/ } \\
\text { Unit } \\
\text { Time }^{b}\end{array}$ & $\begin{array}{c}\text { No. of } \\
\text { Repeats }\end{array}$ & Comments \\
\hline 14 & OP & $\mathbf{C}$ & 0 & 20 & 1 & & & WR-2721 \\
\hline 14 & OS & C & 0 & 20 & 1 & & & Saline \\
\hline 14 & Co & $\mathbf{G}$ & 206 & 20 & 1 & & & No Injection \\
\hline 14 & CP & $\mathbf{G}$ & 206 & 20 & 1 & & & WR-2721 \\
\hline 14 & $\mathrm{DP}$ & $\mathrm{G}$ & 417 & 20 & 1 & & & WR-2721 \\
\hline 14 & AO & $\mathbf{N}$ & 10 & 20 & 1 & & & No Injection \\
\hline 14 & AP & $\mathbf{N}$ & 10 & 20 & 1 & & & WR-2721 \\
\hline 14 & $\mathrm{AR}$ & $\mathbf{N}$ & 10 & 20 & 1 & & & WR-151327 \\
\hline 14 & $\mathrm{BP}$ & $\mathrm{N}$ & 40 & 20 & 1 & & & WR-2721 \\
\hline 14 & $\mathrm{BR}$ & $\mathbf{N}$ & 40 & 20 & 1 & & & WR-151327 \\
\hline
\end{tabular}

a $\mathrm{C}=$ control; $\mathrm{G}=\boldsymbol{\gamma}$ ray; $\mathrm{N}=$ neutron.

b $w=$ week; $m=$ month.

c In experiment JM-13, an _X code designates the total number of records of all the parts $(A+B+C$, or only $A)$ of the numbered treatment set. 
$K-1$

\section{APPENDIX K:}

COMBINED PATHOLOGY DATABASE <E>: MACRO AND MICRO GLOSSARIES 
K-2 


\section{Combined Pathology Database <E> \\ MACRO Glossary}

Group $1<\mathrm{CDU}>$ Cause of death undetermined

CDU Cause of death undetermined

Tumor Codes

Group $2<L R \_T>$ Lymphoreticular tumors

NTYG Non-thymic lymphoma, generalized

NTYL Non-thymic lymphoma, localized

TTYG Thymic lymphoma, generalized

TTYL Thymic lymphoma, localized

Group 3 <TVAS> Vascular tumors

TVAS Vascular

Group $4<$ TCON> Connective tissue tumors other than lymphoreticular and vascular tumors

$\begin{array}{ll}\text { TBON } & \text { Bone } \\ \text { TBRN } & \text { Brain } \\ \text { TCNS } & \text { Central nervous system } \\ \text { TCON } & \text { Connective tissue (fibrosarcoma) } \\ \text { THRT } & \text { Heart } \\ \text { TMIC } & \text { Miscellaneous connective tissue } \\ \text { TMIN } & \text { Miscellaneous nervous system } \\ \text { TMUS } & \text { Muscle } \\ \text { TPNS } & \text { Peripheral nervous system } \\ \text { TSPL } & \text { Spleen }\end{array}$

Group 5 <ADN> Respiratory system tumors

TADN Lung

TMIL Miscellaneous lung

Group $6<$ TGA_> Harderian gland tumors

THGL Harderian gland 
Group $7<\mathrm{TLIV}>$ Liver and gallbladder tumors

TGBL Gallbladder

TLIV Liver

Group 8 <TKID> Kidney and urinary bladder tumors

TBLA Urinary bladder

TKID Kidney

TMUG Miscellaneous urogenital

Group 9 <TGI_> Gastrointestinal tract tumors

$\begin{array}{ll}\text { TCEC } & \text { Caecum } \\ \text { TCOL } & \text { Colon } \\ \text { TDUO } & \text { Duodenum } \\ \text { TESO } & \text { Esophagus } \\ \text { TILE } & \text { Ileum } \\ \text { TJEJ } & \text { Jejunum } \\ \text { TMID } & \text { Miscellaneous digestive system } \\ \text { TPAN } & \text { Pancreas } \\ \text { TPYL } & \text { Pylorus } \\ \text { TSGL } & \text { Salivary gland } \\ \text { TSTO } & \text { Stomach } \\ \text { TTGE } & \text { Tongue }\end{array}$

Group $10<\mathrm{TADR}>$ Adrenal gland tumors

TADR Adrenal

Group $11<$ TPIT> Pituitary gland tumors

TPIT Pituitary

Group $12<$ TTHY> Thyroid gland tumors

TTRD Thyroid

Group $13<$ TTA_> Testis and seminal vesicle tumors

TSMV Seminal vesicle

TTST Testis

TCGL Cowper's gland

TEPI Epididymis 


\section{<E> MACRO Glossary (Cont.)}

Group 14 <TMAM> Mammary gland tumors

TMGL Mammary gland

Group $15<$ TUTE> Uterine tumors

TUTE Uterus

Group $16<$ TOVE $>$ Ovarian tumors

TOVE Ovary

Group $17<$ TEPO> Skin and other epithelial tumors

THIB Hibernating gland

TMIE Miscellaneous endocrine

TMIG Miscellaneous glandular

TPPT Preputial gland

TPST Prostate

TSKN Skin

TVAG Vagina

Group $18<$ TWCN> Secondary tumors, any site, origin connective tissue

TSEC Secondary

Group $19<\mathrm{T}$-WG $>$ Secondary tumors, any site, origin Harderian gland

TSEC Secondary

Group $20<\mathrm{T}_{-} \mathrm{WR}>$ Secondary tumors, any site, origin lung

TSEC Secondary

Group $21<$ TWEP> All other secondary tumors, any site of origin TSEC Secondary

Nontumor Codes

Group $22<$ MHEP> Liver diseases

CHO Cholecystitis

CIR Cirrhosis

HEP Hepatitis 
<E> MACRO Glossary (Cont.)

Group $23<$ MPNU> Pulmonary diseases

$\begin{array}{ll}\text { EMP } & \text { Emphysema } \\ \text { LOB } & \text { Lobar pneumonia } \\ \text { MUL } & \text { Miscellaneous lung } \\ \text { PNC } & \text { Pneumonitis } \\ \text { PNU } & \text { Pneumonia }\end{array}$

Group $24<\mathrm{MCVD}>$ Cardiovascular diseases

$\begin{array}{ll}\text { MYO } & \text { Myocardium } \\ \text { PCD } & \text { Pericardium } \\ \text { THR } & \text { Thrombus }\end{array}$

Group $25<\mathrm{MCRD}>$ Renal diseases

CRD Chronic renal disease

HINP Hydronephrosis

MIR Miscellaneous renal

PCK Polycystic kidney

Group $26<\mathrm{MOCY}>$ Ovarian cyst

CYS Cyst

Group 27 <MAMY> Amyloidosis

\section{AMY Amyloid}

Group $28<$ O_NT> All other nontumor diseases

$\begin{array}{ll}\text { ABS } & \text { Abscess } \\ \text { ACI } & \text { Acute infection } \\ \text { ADH } & \text { Adhesion } \\ \text { ADR } & \text { Adrenal } \\ \text { ANE } & \text { Anemia } \\ \text { ANU } & \text { Aneurysm } \\ \text { ASC } & \text { Ascites } \\ \text { BAC } & \text { Bacteremia } \\ \text { BDY } & \text { Bloody - HTX or ASC } \\ \text { BLA } & \text { Urinary bladder } \\ \text { BON } & \text { Bone } \\ \text { BRN } & \text { Brain } \\ \text { BSC } & \text { Bloody ascites } \\ \text { CAE } & \text { Caecum } \\ \text { CAL } & \text { Calcification }\end{array}$




\section{$<$ E > MACRO Glossary (Cont.)}

$\begin{array}{ll}\text { CAT } & \text { Cataract } \\ \text { CGL } & \text { Cowper's gland } \\ \text { CLI } & \text { Calculi } \\ \text { CLR } & \text { Clear HTX or ASC } \\ \text { CNS } & \text { Central nervous system } \\ \text { COL } & \text { Colon } \\ \text { DER } & \text { Dermatitis } \\ \text { DHY } & \text { Dehydration } \\ \text { DIV } & \text { Diverticulum } \\ \text { DUO } & \text { Duodenum } \\ \text { EDA } & \text { Edema } \\ \text { EMB } & \text { Embolus } \\ \text { ENT } & \text { Enteritis } \\ \text { EPL } & \text { Epilation } \\ \text { ESO } & \text { Esophagus } \\ \text { FIT } & \text { Fighting } \\ \text { GBL } & \text { Gallbladder } \\ \text { GEN } & \text { External genitalia } \\ \text { GON } & \text { Gonad } \\ \text { GRY } & \text { Grayness } \\ \text { HEM } & \text { Hematoma } \\ \text { HGL } & \text { Harderian gland } \\ \text { HRG } & \text { Hemorrhage } \\ \text { HRT } & \text { Heart } \\ \text { HTX } & \text { Hydrothorax } \\ \text { ILE } & \text { Ileum } \\ \text { INF } & \text { Inflammation } \\ \text { INT } & \text { Intussusception } \\ \text { ISO } & \text { Isograft } \\ \text { JAU } & \text { Jaundice } \\ \text { JEJ } & \text { Jejunum } \\ \text { KID } & \text { Kidney } \\ \text { LIV } & \text { Liver } \\ \text { MAL } & \text { Malocclusion } \\ \text { MET } & \text { Metritis } \\ \text { MGC } & \text { Megacolon } \\ \text { MGL } & \text { Mammary gland } \\ \text { MIC } & \text { Miscellaneous circulatory } \\ \text { MID } & \text { Miscellaneous digestive } \\ \text { MIG } & \text { Miscellaneous urogenital } \\ \text { MIS } & \text { Others, general } \\ \text { MKY } & \text { Milky } \\ \text { MSC } & \text { Milky ascites } \\ \text { NEC } & \text { Necrosis } \\ \text { OBE } & \text { Obese } \\ \text { OBS } & \text { Obstruction } \\ & \end{array}$




\section{$<$ E> MACRO Glossary (Cont.)}

OVE Ovary

PAN Pancreatitis

PAR Paralysis

PEN Penis

PER Peritonitis

PGL Preputial gland

PIT Pituitary

PRF Perforation

PRO Prolapse

PST Prostate

SEM Seminal vesicle

SGL Salivary gland

SPL Spleen

STO Stomach

TEP Testis and epididymis

TGE Tongue

TRD Thyroid

TWI Twister

TYP Typhlitis

ULC Ulcer

UTE Uterus

VAG Vagina

VOL Volvulus 


\section{Combined Pathology Database $<\mathrm{E}>$ \\ MICRO Glossary}

Group $1<\mathrm{CDU}>$ Cause of death undetermined

MCDU Cause of death undetermined

Tumor Codes

Group $2<\mathrm{LR} \_\mathrm{T}>$ Lymphoreticular tumors

TLHL Histiocytic leukemia

TLHS Histiocytic lymphoma (reticulum cell tumor, type A)

TLLL Lymphocytic-lymphoblastic leukemia

TLLS Lymphocytic-lymphoblastic lymphoma

TLML Myelogenous leukemia

TLPS Plasma cell tumor

TLSL Undifferentiated leukemia

TLSS Undifferentiated lymphoma

TLUS Unclassified lymphoma

TLXI Mixed histiocytic-lymphocytic leukemia

TLXS Mixed histiocytic-lymphocytic lymphoma (RCT, type B)

Group 3 <TVAS> Vascular tumors

TEVO Hemangioma, spleen

TLVO Hemangioma, lymphoreticular tissue

TOVO Hemangioma, ovary

THVO Hemangioma, liver

TCVO Hemangioma, connective tissue

TMVO Hemangioma, muscle

TBVO Hemangioma, sternal marrow

TIVO Hemangioma, gastrointestinal tract

TDVO Hemangioma, urinary bladder

TUVO Hemangioma, uterus

TAVO Hemangioma, adrenal

TTVO Hemangioma, testis

TEVS Angiosarcoma, spleen

TLVS Angiosarcoma, lymph node

TRVS Angiosarcoma, lung

TOVS Angiosarcoma, ovary

TKVS Angiosarcoma, kidney

THVS Angiosarcoma, liver

TCVS Angiosarcoma, connective tissue

TMVS Angiosarcoma, muscle

TBVS Angiosarcoma, bone

TSVS Angiosarcoma, skin 


\title{
<E> MICRO Glossary (Cont.)
}

\author{
TIVS Angiosarcoma, gastrointestinal tract \\ TDVS Angiosarcoma, urinary bladder \\ TUVS Angiosarcoma, uterus \\ TPVS Angiosarcoma, pituitary \\ TTVS Angiosarcoma, testis \\ TVVS Angiosarcoma, seminal vesicle \\ TNVS Angiosarcoma, nervous system \\ TYVS Angiosarcoma, heart \\ TXVS Angiosarcoma, site specified in comment
}

Group 4 <CON> Connective tissue tumors other than lymphoreticular and vascular tumors

$\begin{array}{ll}\text { TEFS } & \text { Fibrosarcoma, spleen } \\ \text { TKFS } & \text { Fibrosarcoma, kidney } \\ \text { TLFS } & \text { Fibrosarcoma, lymph node, site specified in comment } \\ \text { THFO } & \text { Fibroma, liver } \\ \text { TCFO } & \text { Fibroma, connective tissue } \\ \text { TCFS } & \text { Fibrosarcoma, connective tissue } \\ \text { TCSS } & \text { Undifferentiated connective tissue sarcoma } \\ \text { TMFS } & \text { Fibrosarcoma, muscle } \\ \text { TMSS } & \text { Undifferentiated sarcoma, muscle } \\ \text { TBFS } & \text { Fibrosarcoma, bone } \\ \text { TSFS } & \text { Fibrosarcoma, skin } \\ \text { TSSS } & \text { Undifferentiated sarcoma, skin } \\ \text { TIFO } & \text { Fibroma, gastrointestinal tract } \\ \text { TIFS } & \text { Fibrosarcoma, gastrointestinal tract } \\ \text { TDFS } & \text { Fibrosarcoma, urinary bladder } \\ \text { TUFO } & \text { Fibroma, uterus } \\ \text { TUUS } & \text { Sarcoma, uterus, undetermined type } \\ \text { TTFA } & \text { Fibroma, testis } \\ \text { TTFS } & \text { Fibrosarcoma, testis } \\ \text { TVFO } & \text { Fibroma, seminal vesicle } \\ \text { TVFS } & \text { Fibrosarcoma, seminal vesicle } \\ \text { TVSS } & \text { Undifferentiated sarcoma, seminal vesicle } \\ \text { TNFO } & \text { Fibroma, nervous system } \\ \text { TNMS } & \text { Meningeal sarcoma, nervous system } \\ \text { TYFS } & \text { Fibrosarcoma, heart } \\ \text { TXFS } & \text { Fibrosarcoma, site specified in comment } \\ \text { TXUS } & \text { Undifferentiated sarcoma, site specified in comment } \\ \text { TCMS } & \text { Mast cell tumor, connective tissue } \\ \text { TCOO } & \text { Osteoma, connective tissue } \\ \text { TMLS } & \text { Leiomyosarcoma, muscle } \\ \text { TMRO } & \text { Rhabdomyoma, muscle } \\ \text { TMRS } & \text { Rhabdomyosarcoma, muscle } \\ \text { TMSO } & \text { Leiomyoma, muscle } \\ & \end{array}$


$<$ E> MICRO Glossary (Cont.)

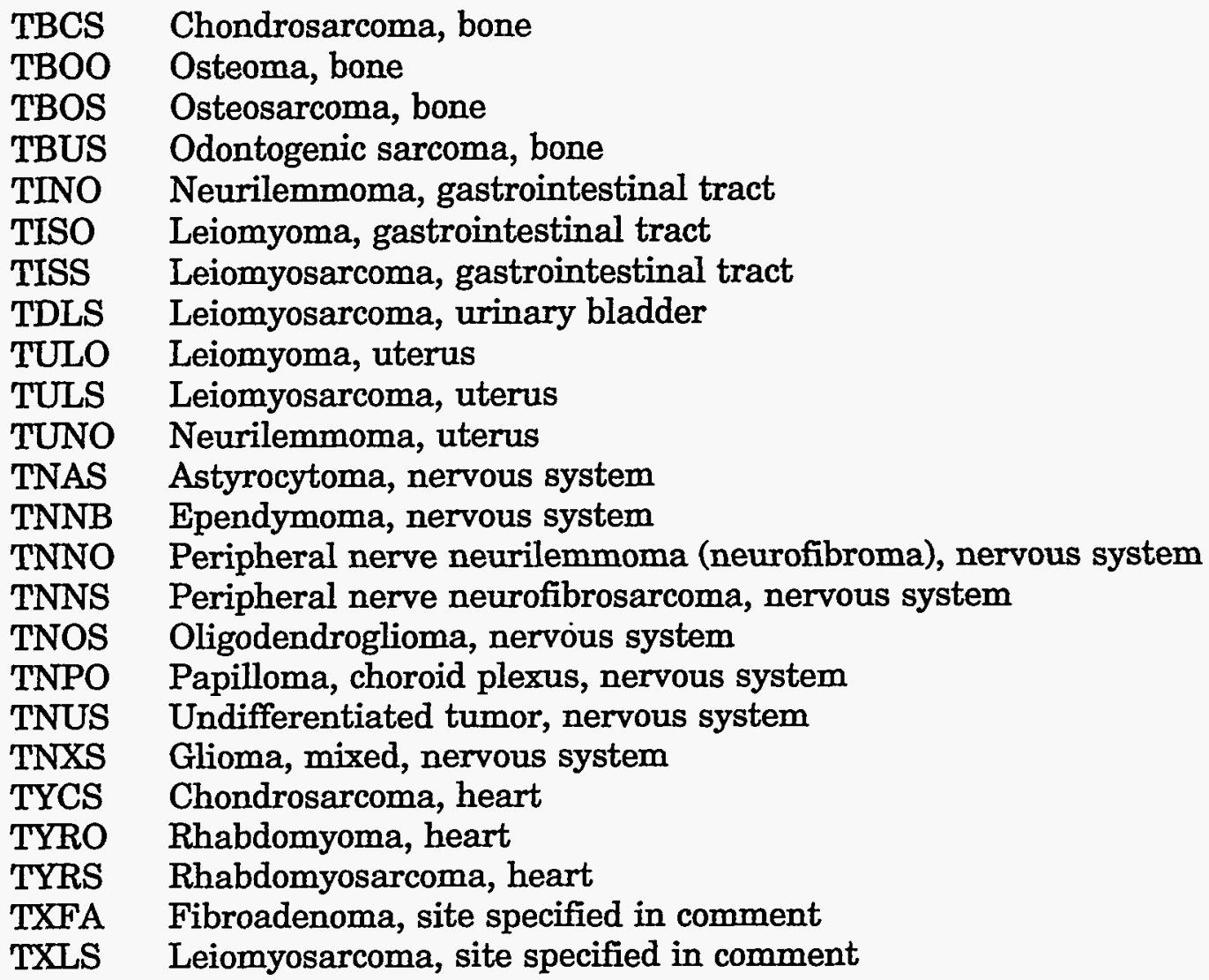

Group $5<\mathrm{TADN}>$ Respiratory system tumors

TRAA Alveologenic adenoma

TRAC Alveologenic adenocarcinoma

TRCO Cystadenoma

Group $6<\mathrm{TGA}>$ Harderian gland tumors

TGAC Adenocarcinoma

TGAO Papillary cystadenoma

TGSC Undifferentiated tumor

Group 7 <LIV> Liver and gallbladder tumors

THAA Adenoma (hepatoma)

THAC Hepatocarcinoma

THAO Hyperplastic nodule (pre-neoplastic nodule)

THCC Cholangiocarcinoma

THCO Cholangioma (cholangiomatosis) 
<E> MICRO Glossary (Cont.)

Group $8<$ TKID> Kidney and urinary bladder tumors

Kidney

TKAA Renal adenoma

TKAC Renal tubular tumor (adenocarcinoma)

TKCA Cystadenoma

TKPA Renal adenoma (papillary)

TKTC Renal pelvic transitional cell tumor

Urinary bladder

TDEC Squamous cell carcinoma

TDTC Transitional cell carcinoma

Group $9<\mathrm{TGI}>\quad$ Gastrointestinal tract tumors

TIAC Adenocarcinoma

TIAO Adenoma

TIEC Squamous cell carcinoma

TIPL Polyp (plaque), pyloric region

TIPO Polyps

TISC Undifferentiated carcinoma

Group $10<$ TADR $>$ Adrenal gland tumors

TACC Cortical carcinoma

TACO Cortical adenoma

TAUO Tumor (undetermined cell type)

TANS Medullary neuroblastoma/ganglioneuroma

TAPS Medullary pheochromocytoma

Group 11 <TPIT> Pituitary gland tumors

TPAA Acidophilic adenoma

TPAC Carcinoma

TPAO Adenoma

Group $12<\mathrm{TTHY}>$ Thyroid gland tumors

TZAC Adenocarcinoma

TZAO Adenoma

Group 13 <TA_> Testis and seminal vesicle tumors

Testis

TTAC Carcinoma

TTGC Seminoma 


\section{$<$ E $>$ MICRO Glossary (Cont.)}

TTIO Interstitial cell tumor (Leydig)

TTKC Sertoli cell tumor

TTQC Embryonal carcinoma

Seminal vesicle

TVAO Adenoma

TVUO Tumor (undetermined cell type)

Group $14<$ TMAM> Mammary gland tumors

TMAA Adenocarcinoma A (alveolar)

TMAB Adenocarcinoma B (ductal, predominantly)

TMAC Adenocarcinoma C (fibrosarcoma)

TMAT Adenoacanthoma

TMUO Mammary gland tumor (undetermined type)

Group $15<$ TUTE> Uterine tumors

TUAC Adenocarcinoma

TUAO Adenoma (including papillary type)

TUEC Squamous cell carcinoma

Group $16<$ TOVE> Ovarian tumors

TOAC Adenocarcinoma

TOAO Adenoma (also papillary adenoma)

TOCO Cystadenoma

TOGC Granulosa cell tumor

TOPA Papillary adenoma

TOSC Undifferentiated carcinoma

TOTA Tubular adenoma

TOTO Luteoma (thecoma)

Group $17<$ TEPO> Skin and other epithelial tumors

Skin

TSAO Adenoma

TSBC Basal cell carcinoma (hair follicle tumor)

TSDO Sebaceous gland adenoma

TSEC Squamous cell carcinoma

TSPO Papilloma

Rare tissues with tumors

TXAC Adenocarcinoma

TXAO Adenoma, site specified in comment

TXEC Squamous cell carcinoma, site specified in comment 
<E> MICRO Glossary (Cont.)

Group $18<\mathrm{TWCN}>$ Secondary tumors, any site, origin connective tissue tumor

Lymphoreticular tissue

TLWB Origin, bone

TLWC Origin, connective tissue

TLWM Origin, muscle

TLWN Origin, nervous system

TLWY Origin, heart

Lung

TRWB Origin, bone

TRWC Origin, connective tissue

TRWN Origin, nervous system

TRWY Origin, heart

Ovary

TOWB Origin, bone

Kidney

TKWB Origin, bone

TKWC Origin, connective tissue

TKWN Origin, nervous system

Liver

THWB Origin, bone

THWC Origin, connective tissue

THWM Origin, muscle

THWN Origin, nervous system

THWY Origin, heart

Connective tissue

TCWB Origin, bone

TCWN Origin, nervous tissue

Muscle

TMWB Origin, bone

TMWC Origin, connective tissue

TMWN Origin, nervous system

Bone

TBWM Origin, muscle

TBWN Origin, nervous tissue 


\section{$<$ E> MICRO Glossary (Cont.)}

\section{Skin}

TSWB Origin, bone

TSWC Origin, connective tissue

TSWN Origin, nervous system

Gastrointestinal tract

TIWB Origin, bone

Adrenal

TAWM Origin, muscle

Harderian gland

TGWC Origin, connective tissue

Nervous system

TNWB Origin, bone

TNWC Origin, connective tissue

TNWM Origin, muscle

Heart

TYWB Origin, bone

TYWM Origin, muscle

TYWC Origin, connective tissue

Rare tissues with tumors

TXWB Origin, bone

TXWC Origin, connective tissue

TXWM Origin, muscle

Spleen

TEWB Origin, bone

TEWC Origin, connective tissue

TEWM Origin, muscle

Group $19<$ T_WG $>$ Secondary tumors, any site, origin Harderian gland

TLWG Lymphoreticular tissue

TRWG Lung

TKWG Kidney

THWG Liver

TCWG Connective tissue

TMWG Muscle

TBWG Bone

TNWG Nervous system

TXWG Rare tissues

TYWG Heart 
$<$ E $>$ MICRO Glossary (Cont.)

Group $20<\mathrm{T}_{-} \mathrm{WR}>$ Secondary tumors, any site, origin lung

TLWR Lymphoreticular tissue

TKWR Kidney

THWR Liver

TCWR Connective tissue

TMWR Muscle

TBWR Bone

TAWR Adrenal

TNWR Nervous system

TYWR Heart

TXWR Rare tissues

Group $21<$ TWEP> All other secondary tumors, any site

$\begin{array}{cl}\text { Spleen } & \\ \text { TEWD } & \text { Origin, urinary bladder } \\ \text { TEWH } & \text { Origin, liver } \\ \text { TEWK } & \text { Origin, kidney } \\ \text { TEWS } & \text { Origin, skin } \\ \text { TEWT } & \text { Origin, testis } \\ \text { TEWU } & \text { Origin, uterus } \\ & \\ \text { Lymphoreticular tissue } \\ \text { TLWA } & \text { Origin, adrenal } \\ \text { TLWH } & \text { Origin, liver } \\ \text { TLWI } & \text { Origin, intestinal tract } \\ \text { TLWK } & \text { Origin, kidney } \\ \text { TLWO } & \text { Origin, ovary } \\ \text { TLWP } & \text { Origin, pituitary } \\ \text { TLWS } & \text { Origin, skin } \\ \text { TLWT } & \text { Origin, testis } \\ \text { TLWU } & \text { Origin, uterus } \\ \text { TLWZ } & \text { Origin, thyroid } \\ & \\ \text { Lung } & \\ \text { TRWA } & \text { Origin, adrenal } \\ \text { TRWH } & \text { Origin, liver } \\ \text { TRWI } & \text { Origin, intestinal tract } \\ \text { TRWK } & \text { Origin, kidney } \\ \text { TRWO } & \text { Origin, ovary } \\ \text { TRWP } & \text { Origin, pituitary } \\ \text { TRWS } & \text { Origin, skin } \\ \text { TRWT } & \text { Origin, testis } \\ \text { TRWU } & \text { Origin, uterus } \\ & \end{array}$




\section{<E> MICRO Glossary (Cont.)}

TRWV Origin, seminal vesicle

TRWZ Origin, thyroid

Kidney

TKWA Origin, adrenal

TKWH Origin, liver

TKWI Origin, intestinal tract

TKWO Origin, ovary

TKWP Origin, pituitary

TKWS Origin, skin

TKWU Origin, uterus

TKWZ Origin, thyroid

Liver

THWA Origin, adrenal

THWD Origin, urinary bladder

THWI Origin, intestinal tract

THWK Origin, kidney

THWO Origin, ovary

THWP Origin, pituitary

THWS Origin, skin

THWU Origin, uterus

THWV Origin, seminal vesicle

THWZ Origin, thyroid

Connective tissue

TCWA Origin, adrenal

TCWD Origin, urinary bladder

TCWH Origin, liver

TCWI Origin, intestinal tract

TCWK Origin, kidney

TCWO Origin, ovary

TCWP Origin, pituitary

TCWS Origin, skin

TCWZ Origin, thyroid

Muscle

TMWA Origin, adrenal

TMWD Origin, urinary bladder

TMWH Origin, liver

TMWK Origin, kidney

TMWM Origin, mammary gland

TMWS Origin, skin

TMWT Origin, testis

TMWZ Origin, thyroid 
Bone

TBWS Origin, skin

Gastrointestinal tract

TIWO Origin, ovary

TIWT Origin, testis

TIWU Origin, uterus

TIWZ Origin, thyroid

Uterus

TUWO Origin, ovary

Adrenal

TAWI Origin, intestine

TAWK Origin, kidney

TAWO Origin, ovary

TAWS Origin, skin

TAWU Origin, uterus

TAWZ Origin, thyroid

Heart

TYWA Origin, adrenal

TYWH Origin, liver

TYWK Origin, kidney

TYWO Origin, ovary

TYWS Origin, skin

TYWT Origin, testis

TYWU Origin, uterus

Rare tissues with tumors

TXWU Origin, uterus

TXWV Origin, seminal vesicle

Seminal vesicle

TVWD Origin, urinary bladder

Harderian gland

TGWS Origin, skin

Nervous system

TNWK Origin, kidney

TNWO Origin, ovary

TNWS Origin, skin

TNWP Origin, pituitary 


\section{$<$ E $>$ MICRO Glossary (Cont.)}

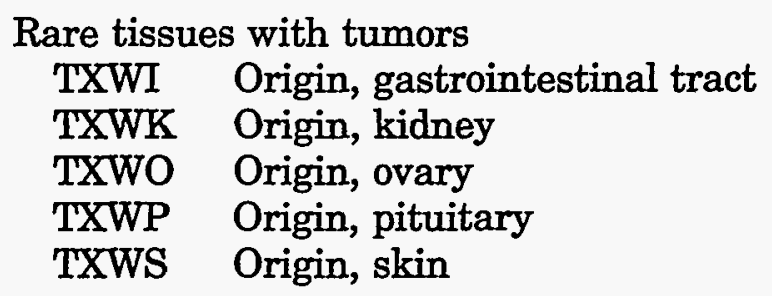

Nontumor Codes

Group $22<\mathrm{MHEP}>$ Liver diseases
MHCN Hepatitis, coagulative - focal
MHCY Hepatic cyst
MHHD Hepatic, hydropic degeneration
MHIA Hepatitis, acute
MHIC Hepatitis, chronic
MHIT Hepatitis, toxic
MHLD Lipidosis (fatty metamorphosis)

Group $23<\mathrm{MPNU}>$ Pulmonary diseases

MPNC Lung congestion

MPNI Pneumonitis (interstitial), acute and chronic

MPNU Pneumonia, acute and subacute

MRMP Murine pneumonia

Group $24<\mathrm{MCVD}>$ Cardiovascular diseases
MECA Acute endocarditis
MECC Chronic endocarditis (valvular)
MMCA Acute myocarditis
MMCC Chronic myocarditis
MPAN Pan/polyarteritis nodosa
MPCA Acute pericarditis
MPCC Chronic pericarditis
MTHR Thrombosis, auricular

Group $25<\mathrm{MCRD}>$ Renal diseases

MCRD Chronic renal disease, unspecified

MINA Interstitial nephritis, acute

MINC Interstitial nephritis, chronic

MPNE Pyelonephritis, acute

MPNP Pyelonephritis (pyonephritis) 


\section{$<$ E $>$ MICRO Glossary (Cont.)}

Group $26<\mathrm{MOCY}>$ Ovarian cyst

MOCY Ovary or testicle, cystic

Group 27 <MAMY> Amyloidosis

MATA Amyloidosis, one or more organs involved

Group $28<\mathrm{O} \_\mathrm{NT}>$ Other nontumor diseases

Skin

MSDA Dermatitis, acute

MSDC Dermatitis, chronic

MSKA Acanthosis

Digestive

MEIC Oesophagitis, chronic

Jejunum_/leum_/Duodenum_/Colon_/Caecum

MICY Cyst, site specified in comment

MIFC Fatty change, site specified in comment

MIIA Enteritis, acute, site specified in comment

MIIC Enteritis, chronic, site specified in comment

Colon

MCLC Colitis, chronic

MCMZ Parasite, metazoan

Salivary glands

MSAA Sialadenitis, acute

MSAC Sialadenitis, chronic

MSGF Fibrosis

Harderian gland

MGAA Acute inflammation

MGAC Chronic inflammation

MGGF Fibrosis

Pancreas

MPNA Pancreatitis, acute

Ureter

MURA Ureteritis, acute

MURC Ureteritis, chronic

MURH Ureteral epithelial hyperplasia 


\section{$<$ E > MICRO Glossary (Cont.)}

Urinary bladder

MUCA Urinary cystitis, acute

MUCC Urinary cystitis, chronic

Prostate

MPRA Prostatitis, acute

MPRH Prostatic hyperplasia

MPRS Prostatic stasis

Seminal vesicles

MSVA Acute inflammation

MSVH Hyperplasia

MSVS Stasis

Testis/ovary

MOAT Ovarian or testicular atrophy

MOIA Acute infection

Uterus

MMCH Uterine cystic hyperplasia

MMTA Metritis, acute

MIMTC Metritis, chronic

Mammary glands

MMDE Mammary, ductal ectasia (galactocoele)

MMMA Acute inflammation (mastitis)

MMMC Chronic inflammation (including subacute)

Adrenal cortex

MABA Ceroid, or brown, atrophy

MACN Coagulation necrosis, zone specified in comment

MAZG Metaplasia zona glomerulosa

MAZX Fibrosis of reticular zone ("X-zone")

Parathyroid

MPTH Hypertrophy, hyperplasia

Thyroid

MSTA Thyroiditis, acute

MSTH Hyperplasia

Bone marrow

MBMZ Atrophic or aplastic 


\section{<E> MICRO Glossary (Cont.)}

\section{Spleen \\ MSCN Coagulation necrosis \\ MSLC Lymphoid hyperplasia \\ MSPZ Atrophic or aplastic}

Lymph nodes

MADM Mesenteric lymph node, or mesenteric disease

MADS Submaxillary (cervical) adenitis

Nervous system

MNIA Infection, acute, site specified in comment

General diseases or conditions

MCIG Septicemia, subacute or acute

MMEI Middle ear infection (vestibular disease), acute

MROD Renal osteodystrophy

MXWI Peritonitis, general or local

MRPU Pleuritis, general or local 
APPENDIX L:

COMBINED PATHOLOGY DATABASE <F>: MACRO AND MICRO GLOSSARIES 
$L-2$ 


\section{Combined Pathology Database $<F>$ \\ MACRO Glossary}

Group $1<\mathrm{PR} \_\mathrm{T}>$ Primary tumors

NTYG Non-thymic lymphoma, generalized

NTYL Non-thymic lymphoma, localized

TTYG Thymic lymphoma, generalized

TTYL Thymic lymphoma, localized

TVAS Vascular

TBON Bone

TBRN Brain

TCNS Central nervous system

TCON Connective tissue (fibrosarcoma)

THRT Heart

TMIC Miscellaneous connective tissue

TMIN Miscellaneous nervous system

TMUS Muscle

TPNS Peripheral nervous system

TSPL Spleen

TADN Lung

TMIL Miscellaneous lung

TOVE Ovary

TGBL Gallbladder

TLIV Liver

TBLA Urinary bladder

TKID Kidney

TMUG Miscellaneous urogenital

TCEC Caecum

TCOL Colon

TDUO Duodenum

TESO Esophagus

TILE Ileum

TJEJ Jejunum

TMID Miscellaneous digestive system

TPAN Pancreas

TPYL Pylorus

TSGL Salivary gland

TSTO Stomach

TTGE Tongue

THIB Hibernating gland

TMIE Miscellaneous endocrine

TMIG Miscellaneous glandular

TPPT Preputial gland

TPST Prostate

TSKN Skin

TVAG Vagina 


$\begin{array}{ll}\text { THGL } & \text { Harderian gland } \\ \text { TPIT } & \text { Pituitary } \\ \text { TTRD } & \text { Thyroid } \\ \text { TSMV } & \text { Seminal vesicle } \\ \text { TTST } & \text { Testis } \\ \text { TCGL } & \text { Cowper's gland } \\ \text { TEPI } & \text { Epididymis } \\ \text { TMGL } & \text { Mammary gland } \\ \text { TUTE } & \text { Uterus } \\ \text { TADR } & \text { Adrenal }\end{array}$

Group $2<\mathrm{CT}$ - $>$ Primary connective tissue tumors

NTYG Non-thymic lymphoma, generalized

NTYL Non-thymic lymphoma, localized

TTYG Thymic lymphoma, generalized

TTYL Thymic lymphoma, localized

TVAS Vascular

TBON Bone

TBRN Brain

TCNS Central nervous system

TCON Connective tissue (fibrosarcoma)

THRT Heart

TMIC Miscellaneous connective tissue

TMIN Miscellaneous nervous system

TMUS Muscle

TPNS Peripheral nervous system

TSPL Spleen

Group $3<\mathrm{EP} \_\mathrm{T}>$ Primary epithelial tumors excluding ovarian tumors

$\begin{array}{ll}\text { TADN } & \text { Lung } \\ \text { TMIL } & \text { Miscellaneous lung } \\ \text { TGBL } & \text { Gallbladder } \\ \text { TLIV } & \text { Liver } \\ \text { TBLA } & \text { Urinary bladder } \\ \text { TKID } & \text { Kidney } \\ \text { TMUG } & \text { Miscellaneous urogenital } \\ \text { TCEC } & \text { Caecum } \\ \text { TCOL } & \text { Colon } \\ \text { TDUO } & \text { Duodenum } \\ \text { TESO } & \text { Esophagus } \\ \text { TILE } & \text { Ileum } \\ \text { TJEJ } & \text { Jejunum } \\ \text { TMID } & \text { Miscellaneous digestive system } \\ \text { TPAN } & \text { Pancreas }\end{array}$




\section{$<$ F $>$ MACRO Glossary (Cont.)}

$\begin{array}{ll}\text { TPYL } & \text { Pylorus } \\ \text { TSGL } & \text { Salivary gland } \\ \text { TSTO } & \text { Stomach } \\ \text { TTGE } & \text { Tongue } \\ \text { THIB } & \text { Hibernating gland } \\ \text { TMIE } & \text { Miscellaneous endocrine } \\ \text { TMIG } & \text { Miscellaneous glandular } \\ \text { TPPT } & \text { Preputial gland } \\ \text { TPST } & \text { Prostate } \\ \text { TSKN } & \text { Skin } \\ \text { TVAG } & \text { Vagina } \\ \text { THGL } & \text { Harderian gland } \\ \text { TPIT } & \text { Pituitary } \\ \text { TTRD } & \text { Thyroid } \\ \text { TSMV } & \text { Seminal vesicle } \\ \text { TTST } & \text { Testis } \\ \text { TCGL } & \text { Cowper's gland } \\ \text { TEPI } & \text { Epididymis } \\ \text { TMGL } & \text { Mammary gland } \\ \text { TUTE } & \text { Uterus } \\ \text { TADR } & \text { Adrenal }\end{array}$

Group $4<\mathrm{LR}$ T> Lymphoreticular tumors

NTYG Non-thymic lymphoma, generalized

NTYL Non-thymic lymphoma, localized

TTYG Thymic lymphoma, generalized

TTYL Thymic lymphoma, localized

Group 5 <TLHS> Histiocytic lymphoma

Null table . Codes in <MICRO $>$ only

Group 6 <TLLL> Lymphocytic-lymphoblastic leukemia

Null table Codes in $<\mathrm{MICRO}>$ only

Group 7 <LLS> Lymphocytic-lymphoblastic lymphoma

Null table Codes in <MICRO $>$ only

Group 8 <TLUS> Unclassified lymphoma

Null table Codes in $<$ MICRO $>$ only 


\section{$<$ F> MACRO Glossary (Cont.)}

Group 9 <TLXS> Mixed histiocytic-lymphocytic lymphoma

Null table Codes in <MICRO $>$ only

Group $10<$ TLOT> All other lymphoreticular tumors

Null table Codes in $<$ MICRO $>$ only

Group $11<\mathrm{T}_{-} \mathrm{VO}>$ Hemangioma, any site

Null table Codes in $<$ MICRO $>$ only

Group $12<\mathrm{T}$-VS $>$ Angiosarcoma, any site

Null table Codes in $<$ MICRO $>$ only

Group $13<$ TVAS> Vascular tumors

TVAS Vascular

Group 14 (T_FS> Fibroma, fibrosarcoma, undifferentiated sarcoma, any site

Null table Codes in $<M I C R O>$ only

Group $15<\mathrm{TCOT}>$ All other primary connective tissue tumors

Null table Codes in $<$ MICRO $>$ only

Group $16<$ TCON> Connective tissue tumors other than lymphoreticular and vascular tumors

$\begin{array}{ll}\text { TBON } & \text { Bone } \\ \text { TBRN } & \text { Brain } \\ \text { TCNS } & \text { Central nervous system } \\ \text { TCON } & \text { Connective tissue (fibrosarcoma) } \\ \text { THRT } & \text { Heart } \\ \text { TMIC } & \text { Miscellaneous connective tissue } \\ \text { TMIN } & \text { Miscellaneous nervous system } \\ \text { TMUS } & \text { Muscle } \\ \text { TPNS } & \text { Peripheral nervous system } \\ \text { TSPL } & \text { Spleen }\end{array}$

Group $17<$ THA_> Liver, hepatocellular tumors

Null table Codes in $<\mathrm{MICRO}>$ only 
$<$ F $>$ MACRO Glossary (Cont.)

Group $18<$ THC_> Liver, bile duct tumors

Null table Codes in $<$ MICRO $>$ only

Group $19<$ TAC_> Adrenal cortical tumors

Null table Codes in $<$ MICRO $>$ only

Group $20<$ TAM_> Adrenal medullary tumors

Null table Codes in $<$ MICRO $>$ only

Group $21<\mathrm{TOVE}>$ Ovarian tumors

TOVE Ovary

Group $22<$ TOGC> Granulosa cell tumor, ovary

Null table Codes in $<$ MICRO $>$ only

Group $23<$ TOTA> Tubular adenoma, ovary

Null table Codes in $<$ MICRO $>$ only

Group 24 <TOTO> Luteoma (thecoma), ovary

Null table Codes in $<$ MICRO $>$ only

Group $25<$ TOOT> All other ovarian tumors

Null table Codes in $<$ MICRO $>$ only

Group $26<\mathrm{KLOG}>\mathrm{Kidney}$, liver, gastrointestinal system, and other tumors

TGBL Gallbladder

TLIV Liver

TBLA Urinary bladder

TKID Kidney

TMUG Miscellaneous urogenital

TCEC Caecum

TCOL Colon

TDUO Duodenum

TESO Esophagus

TILE Meum

TJEJ Jejunum

TMID Miscellaneous digestive system 


\section{<F> MACRO Glossary (Cont.)}

$\begin{array}{ll}\text { TPAN } & \text { Pancreas } \\ \text { TPYL } & \text { Pylorus } \\ \text { TSGL } & \text { Salivary gland } \\ \text { TSTO } & \text { Stomach } \\ \text { TTGE } & \text { Tongue } \\ \text { THIB } & \text { Hibernating gland } \\ \text { TMIE } & \text { Miscellaneous endocrine } \\ \text { TMIG } & \text { Miscellaneous glandular } \\ \text { TPPT } & \text { Preputial gland } \\ \text { TPST } & \text { Prostate } \\ \text { TSKN } & \text { Skin } \\ \text { TVAG } & \text { Vagina }\end{array}$

Group 27 <MAPU> Mammary gland, adrenal gland, pituitary gland, thyroid gland, uterine, testicular, and seminal vesicle tumors

$\begin{array}{ll}\text { TPIT } & \text { Pituitary } \\ \text { TTRD } & \text { Thyroid } \\ \text { TSMV } & \text { Seminal vesicle } \\ \text { TTST } & \text { Testis } \\ \text { TCGL } & \text { Cowper's gland } \\ \text { TEPI } & \text { Epididymis } \\ \text { TMGL } & \text { Mammary gland } \\ \text { TUTE } & \text { Uterus } \\ \text { TADR } & \text { Adrenal }\end{array}$

Group 28 <ENDO> Mammary gland, adrenal gland, pituitary gland, thyroid gland, uterine, testicular, seminal vesicle, and Harderian gland tumors

$\begin{array}{ll}\text { THGL } & \text { Harderian gland } \\ \text { TPIT } & \text { Pituitary } \\ \text { TTRD } & \text { Thyroid } \\ \text { TSMV } & \text { Seminal vesicle } \\ \text { TTST } & \text { Testis } \\ \text { TCGL } & \text { Cowper's gland } \\ \text { TEPI } & \text { Epididymis } \\ \text { TMGL } & \text { Mammary gland } \\ \text { TUTE } & \text { Uterus } \\ \text { TADR } & \text { Adrenal }\end{array}$




\section{Combined Pathology Database $<F>$}

\section{MICRO Glossary}

\section{Group $1<$ PR_T $>$ Primary tumors}

TLFS Fibrosarcoma, lymph node, site specified in comment

TLHL Histiocytic leukemia

TLHS Histiocytic lymphoma (reticulum cell tumor, type A)

TLLL Lymphocytic-lymphoblastic leukemia

TLLS Lymphocytic-lymphoblastic lymphoma

TLML Myelogenous leukemia

TLPS Plasma cell tumor

TLSL Undifferentiated leukemia

TLSS Undifferentiated lymphoma

TLUS Unclassified lymphoma

TLXL Mixed histiocytic-lymphocytic leukemia

TLXS Mixed histiocytic-lymphocytic lymphoma (RCT, type B)

TEVO Hemangioma, spleen

TLVO Hemangioma, lymphoreticular tissue

TOVO Hemangioma, ovary

THVO Hemangioma, liver

TCVO Hemangioma, connective tissue

TMVO Hemangioma, muscle

TBVO Hemangioma, sternal marrow

TIVO Hemangioma, gastrointestinal tract

TDVO Hemangioma, urinary bladder

TUVO Hemangioma, uterus

TAVO Hemangioma, adrenal

TTVO Hemangioma, testis

TEVS Angiosarcoma, spleen

TLVS Angiosarcoma, lymph node

TRVS Angiosarcoma, lung

TOVS Angiosarcoma, ovary

TKVS Angiosarcoma, kidney

THVS Angiosarcoma, liver

TCVS Angiosarcoma, connective tissue

TMVS Angiosarcoma, muscle

TBVS Angiosarcoma, bone

TSVS Angiosarcoma, skin

TIVS Angiosarcoma, gastrointestinal tract

TDVS Angiosarcoma, urinary bladder

TUVS Angiosarcoma, uterus

TPVS Angiosarcoma, pituitary

TTVS Angiosarcoma, testis

TVVS Angiosarcoma, seminal vesicle

TNVS Angiosarcoma, nervous system

TYVS Angiosarcoma, heart 


\section{$<$ F> MICRO Glossary (Cont.)}

TXVS Angiosarcoma, site specified in comment

TEFS Fibrosarcoma, spleen

TKFS Fibrosarcoma, kidney

THFO Fibroma, liver

TCFO Fibroma, connective tissue

TCFS Fibrosarcoma, connective tissue

TCSS Undifferentiated connective tissue sarcoma

TMFS Fibrosarcoma, muscle

TMSS Undifferentiated sarcoma, muscle

TBFS Fibrosarcoma, bone

TSFS Fibrosarcoma, skin

TSSS Undifferentiated sarcoma, skin

TIFO Fibroma, gastrointestinal tract

TIFS Fibrosarcoma, gastrointestinal tract

TDFS Fibrosarcoma, urinary bladder

TUFO Fibroma, uterus

TUUS Sarcoma, uterus, undetermined type

TTFA Fibroma, testis

TTFS Fibrosarcoma, testis

TVFO Fibroma, seminal vesicle

TVFS Fibrosarcoma, seminal vesicle

TVSS Undifferentiated sarcoma, seminal vesicle

TNFO Fibroma, nervous system

TNIMS Meningeal sarcoma, nervous system

TYFS Fibrosarcoma, heart

TXFS Fibrosarcoma, site specified in comment

TXUS Undifferentiated sarcoma, site specified in comment

TCMS Mast cell tumor, connective tissue

TCOO Osteoma, connective tissue

TMLS Leiomyosarcoma, muscle

TMRO Rhabdomyoma, muscle

TMRS Rhabdomyosarcoma, muscle

TMSO Leiomyoma, muscle

TBCS Chondrosarcoma, bone

TBOO Osteoma, bone

TBOS Osteosarcoma, bone

TBUS Odontogenic sarcoma, bone

TINO Neurilemmoma, gastrointestinal tract

TISO Leiomyoma, gastrointestinal tract

TISS Leiomyosarcoma, gastrointestinal tract

TDLS Leiomyosarcoma, urinary bladder

TULO Leiomyoma, uterus

TULS Leiomyosarcoma, uterus

TUNO Neurilemmoma, uterus

TNAS Astrocytoma, nervous system

TNNB Ependymoma, nervous system 


\section{<F> MICRO Glossary (Cont.)}

TNNO Peripheral nerve neurilemmoma (neurofibroma), nervous system

TNNS Peripheral nerve neurofibrosarcoma, nervous system

TNOS Oligodendroglioma, nervous system

TNPO Papilloma, choroid plexus, nervous system

TNUS Undifferentiated tumor, nervous system

TNXS Glioma, mixed, nervous system

TYCS Chondrosarcoma, heart

TYRO Rhabdomyoma, heart

TYRS Rhabdomyosarcoma, heart

TXFA Fibroadenoma, site specified in comment

TXLS Leiomyosarcoma, site specified in comment

TANS Medullary neuroblastoma/ganglioneuroma, adrenal

TAPS Medullary pheochromocytoma, adrenal

Respiratory system

TRAA Alveologenic adenoma

TRAC Alveologenic adenocarcinoma

TRCO Cystadenoma

Mammary gland

TMAA Adenocarcinoma A (alveolar)

TMAB Adenocarcinoma B (ductal, predominantly)

TMAC Adenocarcinoma C (fibrosarcoma)

TMAT Adenoacanthoma

TMUO Mammary gland tumor (undetermined type)

Adrenal cortical tumors

TACC Cortical carcinoma

TACO Cortical adenoma

TAUO Tumor (undetermined cell type)

Pituitary

TPAA Acidophilic adenoma

TPAC Carcinoma

TPAO Adenoma

Thyroid

TZAC Adenocarcinoma

TZAO Adenoma

Uterus

TUAC Adenocarcinoma

TUAO Adenoma (including papillary type)

TUEC Squamous cell carcinoma 


\section{<F> MICRO Glossary (Cont.)}

Testis

TTAC Carcinoma

TTGC Seminoma

TTIO Interstitial cell tumor (Leydig)

TTKC Sertoli cell tumor

TTQC Embryonal carcinoma

Seminal vesicle

TVAO Adenoma

TVUO Tumor (undetermined cell type)

Harderian gland

TGAC Adenocarcinoma

TGAO Papillary cystadenoma

TGSC Undifferentiated tumor

Kidney

TKAA Renal adenoma

TKAC Renal tubular tumor (adenocarcinoma)

TKCA Cystadenoma

TKPA Renal papillary cystadenoma

TKTC Renal pelvic transitional cell tumor

Urinary bladder

TDEC Squamous cell carcinoma

TDTC Transitional cell carcinoma

Liver

THAA Adenoma (hepatoma)

THAC Hepatocarcinoma

THAO Hyperplastic nodule (pre-neoplastic nodule)

THCC Cholangiocarcinoma

THCO Cholangioma (cholangiomatosis)

Gastrointestinal tract

TIAC Adenocarcinoma

TLAO Adenoma

TIEC Squamous cell carcinoma

TIPL Polyp (plaque), pyloric region

TIPO Polyps

TISC Undifferentiated carcinoma

Skin

TSAO Adenoma

TSBC Basal cell carcinoma (hair follicle tumor)

TSDO Sebaceous gland adenoma 


\section{$<$ F> MICRO Glossary (Cont.)}

$\begin{array}{ll}\text { TSEC } & \text { Squamous cell carcinoma } \\ \text { TSPO } & \text { Papilloma }\end{array}$

Rare tissues with tumors

TXAC Adenocarcinoma, site specified in comment

TXAO Adenoma, site specified in comment

TXEC Squamous cell carcinoma, site specified in comment

Ovary

TOAC Adenocarcinoma

TOAO Adenoma (also papillary adenoma)

TOCO Cystadenoma

TOGC Granulosa cell tumor

TOPA Papillary adenoma

TOSC Undifferentiated carcinoma

TOTA Tubular adenoma

TOTO Luteoma (thecoma)

Group $2<\mathrm{CT}$-T $>$ Primary connective tissue tumors

TLFS Fibrosarcoma, lymph node, site specified in comment

TLHL Histiocytic leukemia

TLHS Histiocytic lymphoma (reticulum cell tumor, type A)

TLLL Lymphocytic-lymphoblastic leukemia

TLLS Lymphocytic-lymphoblastic lymphoma

TLML Myelogenous leukemia

TLPS Plasma cell tumor

TLSL Undifferentiated leukemia

TLSS Undifferentiated lymphoma

TLUS Unclassified lymphoma

TLXL Mixed histiocytic-lymphocytic leukemia

TLXS Mixed histiocytic-lymphocytic lymphoma (RCT, type B)

TEVO Hemangioma, spleen

TLVO Hemangioma, lymphoreticular tissue

TOVO Hemangioma, ovary

THVO Hemangioma, liver

TCVO Hemangioma, connective tissue

TMVO Hemangioma, muscle

TBVO Hemangioma, sternal marrow

TIVO Hemangioma, gastrointestinal tract

TDVO Hemangioma, urinary bladder

TUVO Hemangioma, uterus

TAVO Hemangioma, adrenal

TTVO Hemangioma, testis

TEVS Angiosarcoma, spleen

TLVS Angiosarcoma, lymph node 
<F> MICRO Glossary (Cont.)

TRVS

TOVS

TKVS

THVS

TCVS

TMVS

TBVS

TSVS

TIVS

TDVS

TUVS

TPVS

TTVS

TVVS

TNVS

TYVS

TXVS

TEFS

TKFS

THFO

TCFO

TCFS

TCSS

TMFS

TMSS

TBFS

TSFS

TSSS

TIFO

TIFS

TDFS

TUFO

TUUS

TTFA

TTFS

TVFO

TVFS

TVSS

TNFO

TNMS

TYFS

TXFS

TXUS

TCMS

TCOO

TMLS
Angiosarcoma, lung

Angiosarcoma, ovary

Angiosarcoma, kidney

Angiosarcoma, liver

Angiosarcoma, connective tissue

Angiosarcoma, muscle

Angiosarcoma, bone

Angiosarcoma, skin

Angiosarcoma, gastrointestinal tract .

Angiosarcoma, urinary bladder

Angiosarcoma, uterus

Angiosarcoma, pituitary

Angiosarcoma, testis

Angiosarcoma, seminal vesicle

Angiosarcoma, nervous system

Angiosarcoma, heart

Angiosarcoma, site specified in comment

Fibrosarcoma, spleen

Fibrosarcoma, kidney

Fibroma, liver

Fibroma, connective tissue

Fibrosarcoma, connective tissue

Undifferentiated connective tissue sarcoma

Fibrosarcoma, muscle

Undifferentiated sarcoma, muscle

Fibrosarcoma, bone

Fibrosarcoma, skin

Undifferentiated sarcoma, skin

Fibroma, gastrointestinal tract

Fibrosarcoma, gastrointestinal tract

Fibrosarcoma, urinary bladder

Fibroma, uterus

Sarcoma, uterus, undetermined type

Fibroma, testis

Fibrosarcoma, testis

Fibroma, seminal vesicle

Fibrosarcoma, seminal vesicle

Undifferentiated sarcoma, seminal vesicle

Fibroma, nervous system

Meningeal sarcoma, nervous system

Fibrosarcoma, heart

Fibrosarcoma, site specified in comment

Undifferentiated sarcoma, site specified in comment

Mast cell tumor, connective tissue

Osteoma, connective tissue

Leiomyosarcoma, muscle 


\section{<F> MICRO Glossary (Cont.)}

TMRO Rhabdomyoma, muscle

TMRS Rhabdomyosarcoma, muscle

TMSO Leiomyoma, muscle

TBCS Chondrosarcoma, bone

TBOO Osteoma, bone

TBOS Osteosarcoma, bone

TBUS Odontogenic sarcoma, bone

TINO Neurilemmoma, gastrointestinal tract

TISO Leiomyoma, gastrointestinal tract

TISS Leiomyosarcoma, gastrointestinal tract

TDLS Leiomyosarcoma, urinary bladder

TULO Leiomyoma, uterus

TULS Leiomyosarcoma, uterus

TUNO Neurilemmoma, uterus

TNAS Astrocytoma, nervous system

TNNB Ependymoma, nervous system

TNNO Peripheral nerve neurilemmoma (neurofibroma), nervous system

TNNS Peripheral nerve neurofibrosarcoma, nervous system

TNOS Oligodendroglioma, nervous system

TNPO Papilloma, choroid plexus, nervous system

TNUS Undifferentiated tumor, nervous system

TNXS Glioma, mixed, nervous system

TYCS Chrondrosarcoma, heart

TYRO Rhabdomyoma, heart

TYRS Rhabdomyosarcoma, heart

TXFA Fibroadenoma, site specified in comment

TXLS Leiomyosarcoma, site specified in comment

TANS Medullary neuroblastoma/ganglioneuroma, adrenal

TAPS Medullary pheochromocytoma, adrenal

Group $3<$ EP_T $>$ Primary epithelial tumors excluding ovarian tumors

Respiratory system

TRAA Alveologenic adenoma

TRAC Alveologenic adenocarcinoma

TRCO Cystadenoma

Mammary gland

TMAA Adenocarcinoma A (alveolar)

TMAB Adenocarcinoma B (ductal, predominantly)

TMAC Adenocarcinoma C (fibrosarcoma)

TMAT Adenoacanthoma

TMUO Mammary gland tumor (undetermined type) 
Adrenal cortical tumors

TACC Cortical carcinoma

TACO Cortical adenoma

TAUO Tumor (undetermined cell type)

Pituitary

TPAA Acidophilic adenoma

TPAC Carcinoma

TPAO Adenoma

Thyroid

TZAC Adenocarcinoma

TZAO Adenoma

Uterus

TUAC Adenocarcinoma

TUAO Adenoma (including papillary type)

TUEC Squamous cell carcinoma

Testis

TTAC Carcinoma

TTGC Seminoma

TTIO Interstitial cell tumor (Leydig)

TTKC Sertoli cell tumor

TTQC Embryonal carcinoma

Seminal vesicle

TVAO Adenoma

TVUO Tumor (undetermined cell type)

Harderian gland

TGAC Adenocarcinoma

TGAO Papillary cystadenoma

TGSC Undifferentiated tumor

Kidney

TKAA Renal adenoma

TKAC Renal tubular tumor (adenocarcinoma)

TKCA Cystadenoma

TKPA Renal papillary cystadenoma

TKTC Renal pelvic transitional cell tumor

Urinary bladder

TDEC Squamous cell carcinoma

TDTC Transitional cell carcinoma 


\section{<F> MICRO Glossary (Cont.)}

Liver

THAA Adenoma (hepatoma)

THAC Hepatocarcinoma

THAO Hyperplastic nodule (pre-neoplastic nodule)

THCC Cholangiocarcinoma

THCO Cholangioma (cholangiomatosis)

Gastrointestinal tract

TIAC Adenocarcinoma

TIAO Adenoma

TIEC Squamous cell carcinoma

TIPL Polyp (plaque), pyloric region

TIPO Polyps

TISC Undifferentiated carcinoma

Skin

TSAO Adenoma

TSBC Basal cell carcinoma (hair follicle tumor)

TSDO Sebaceous gland adenoma

TSEC Squamous cell carcinoma

TSPO Papilloma

Rare tissues with tumor

TXAC Adenocarcinoma, site specified in comment

TXAO Adenoma, site specified in comment

TXEC Squamous cell carcinoma, site specified in comment

Group $4<$ LR_T> Lymphoreticular tumors

TLHL Histiocytic leukemia

TLHS Histiocytic lymphoma (reticulum cell tumor, type A)

TLLL Lymphocytic-lymphoblastic leukemia

TLLS Lymphocytic-lymphoblastic lymphoma

TLML Myelogenous leukemia

TLPS Plasma cell tumor

TLSL Undifferentiated leukemia

TLSS Undifferentiated lymphoma

TLUS Unclassified lymphoma

TLXL Mixed histiocytic-lymphocytic leukemia

TLXS Mixed histiocytic-lymphocytic lymphoma (RCT, type B)

Group 5 <LHS> Histiocytic lymphoma

TLHS Histiocytic lymphoma (reticulum cell tumor, type A) 


\section{$<$ F $>$ MICRO Glossary (Cont.)}

Group $6<$ TLLL> Lymphocytic-lymphoblastic leukemia

TLLL Lymphocytic-lymphoblastic leukemia

Group 7 <TLLS> Lymphocytic-lymphoblastic lymphoma

TLLS Lymphocytic-lymphoblastic lymphoma

Group 8 <TLUS> Unclassified lymphoma

TLUS Unclassified lymphoma

Group 9 <TLXS> Mixed histiocytic-lymphocytic lymphoma

TLXS Mixed histiocytic-lymphocytic lymphoma (RCT, type B)

Group $10<$ TLOT> All other lymphoreticular tumors

TLHL Histiocytic leukemia

TLML Myelogenous leukemia

TLPS Plasma cell tumor

TLSL Undifferentiated leukemia

TLSS Undifferentiated lymphoma

TLXI Mixed histiocytic-lymphocytic leukemia

Group $11<\mathrm{T} \_$VO $>$Hemangioma, any site

TEVO Hemangioma, spleen

TLVO Hemangioma, lymphoreticular tissue

TOVO Hemangioma, ovary

THVO Hemangioma, liver

TCVO Hemangioma, connective tissue

TMVO Hemangioma, muscle

TBVO Hemangioma, sternal marrow

TIVO Hemangioma, gastrointestinal tract

TDVO Hemangioma, urinary bladder

TUVO Hemangioma, uterus

TAVO Hemangioma, adrenal

TTVO Hemangioma, testis

Group $12<\mathrm{T}$ _VS $>$ Angiosarcoma, any site

TEVS Angiosarcoma, spleen

TLVS Angiosarcoma, lymph node

TRVS Angiosarcoma, lung

TOVS Angiosarcoma, ovary 


\section{<F> MICRO Glossary (Cont.)}

$\begin{array}{ll}\text { TKVS } & \text { Angiosarcoma, kidney } \\ \text { THVS } & \text { Angiosarcoma, liver } \\ \text { TCVS } & \text { Angiosarcoma, connective tissue } \\ \text { TMVS } & \text { Angiosarcoma, muscle } \\ \text { TBVS } & \text { Angiosarcoma, bone } \\ \text { TSVS } & \text { Angiosarcoma, skin } \\ \text { TIVS } & \text { Angiosarcoma, gastrointestinal tract } \\ \text { TDVS } & \text { Angiosarcoma, urinary bladder } \\ \text { TUVS } & \text { Angiosarcoma, uterus } \\ \text { TPVS } & \text { Angiosarcoma, pituitary } \\ \text { TTVS } & \text { Angiosarcoma, testis } \\ \text { TVVS } & \text { Angiosarcoma, seminal vesicle } \\ \text { TNVS } & \text { Angiosarcoma, nervous system } \\ \text { TYVS } & \text { Angiosarcoma, heart } \\ \text { TXVS } & \text { Angiosarcoma, site specified in comment }\end{array}$

Group 13 <TVAS> Vascular tumors

$\begin{array}{ll}\text { TEVO } & \text { Hemangioma, spleen } \\ \text { TLVO } & \text { Hemangioma, lymphoreticular tissue } \\ \text { TOVO } & \text { Hemangioma, ovary } \\ \text { THVO } & \text { Hemangioma, liver } \\ \text { TCVO } & \text { Hemangioma, connective tissue } \\ \text { TMVO } & \text { Hemangioma, muscle } \\ \text { TBVO } & \text { Hemangioma, sternal marrow } \\ \text { TVO } & \text { Hemangioma, gastrointestinal tract } \\ \text { TDVO } & \text { Hemangioma, urinary bladder } \\ \text { TUVO } & \text { Hemangioma, uterus } \\ \text { TAVO } & \text { Hemangioma, adrenal } \\ \text { TTVO } & \text { Hemangioma, testis } \\ \text { TEVS } & \text { Angiosarcoma, spleen } \\ \text { TLVS } & \text { Angiosarcoma, lymph node } \\ \text { TRVS } & \text { Angiosarcoma, lung } \\ \text { TOVS } & \text { Angiosarcoma, ovary } \\ \text { TKVS } & \text { Angiosarcoma, kidney } \\ \text { THVS } & \text { Angiosarcoma, liver } \\ \text { TCVS } & \text { Angiosarcoma, connective tissue } \\ \text { TMVS } & \text { Angiosarcoma, muscle } \\ \text { TBVS } & \text { Angiosarcoma, bone } \\ \text { TSVS } & \text { Angiosarcoma, skin } \\ \text { TIVS } & \text { Angiosarcoma, gastrointestinal tract } \\ \text { TDVS } & \text { Angiosarcoma, urinary bladder } \\ \text { TUVS } & \text { Angiosarcoma, uterus } \\ \text { TPVS } & \text { Angiosarcoma, pituitary } \\ \text { TTVS } & \text { Angiosarcoma, testis } \\ \text { TVVS } & \text { Angiosarcoma, seminal vesicle }\end{array}$




\section{<F> MICRO Glossary (Cont.)}

TNVS Angiosarcoma, nervous system

TYVS Angiosarcoma, heart

TXVS Angiosarcoma, site specified in comment

Group $14<\mathrm{T}$ FS $>$ Fibroma, fibrosarcoma, undifferentiated sarcoma, any site
TEFS
Fibrosarcoma, spleen
TKFS
Fibrosarcoma, kidney
TLFS
Fibrosarcoma, lymph node, site specified in comment
THFO Fibroma, liver
TCFO
Fibroma, connective tissue
TCFS
Fibrosarcoma, connective tissue
TCSS
Undifferentiated connective tissue sarcoma
TMFS
TMSS
Fibrosarcoma, muscle
TBFS
Undifferentiated sarcoma, muscle
TSFS
Fibrosarcoma, bone
TSSS
Fibrosarcoma, skin
TIFO
Undifferentiated sarcoma, skin
TIFS
Fibroma, gastrointestinal tract
TUFO
Fibrosarcoma, gastrointestinal tract
TUUS
TTEA
TTFS
Fibroma, uterus
Sarcoma, uterus, undetermined type
TVFO
Fibroma, testis
TDFS
Fibrosarcoma, testis
TVFS
Fibroma, seminal vesicle
TVSS
Fibrosarcoma, urinary bladder
TNFO Fibrosarcoma, seminal vesicle
TNMS
TYFS
TXFS
TXUS Undifferentiated sarcoma, seminal vesicle
Fibroma, nervous system
Meningeal sarcoma, nervous system Fibrosarcoma, heart
Fibrosarcoma, site specified in comment
Undifferentiated sarcoma, site specified in comment

Group $15<$ TCOT> All other primary connective tissue tumors

TCMS Mast cell tumor, connective tissue

TCOO Osteoma, connective tissue

TMLS Leiomyosarcoma, muscle

TMRO Rhabdomyoma, muscle

TMRS Rhabdomyosarcoma, muscle

TMSO Leiomyoma, muscle

TBCS Chondrosarcoma, bone

TBOO Osteoma, bone

TBOS Osteosarcoma, bone

TBUS Odontogenic sarcoma, bone 


\section{$<$ F $>$ MICRO Glossary (Cont.)}

TINO Neurilemmoma, gastrointestinal tract

TISO Leiomyoma, gastrointestinal tract

TISS Leiomyosarcoma, gastrointestinal tract

TDLS Leiomyosarcoma, urinary bladder

TULO Leiomyoma, uterus

TULS Leiomyosarcoma, uterus

TUNO Neurilemmoma, uterus

TNAS Astrocytoma, nervous system

TNNB Ependymoma, nervous system

TNNO Peripheral nerve neurilemmoma (neurofibroma), nervous system

TNNS Peripheral nerve neurofibrosarcoma, nervous system

TNOS Oligodendroglioma, nervous system

TNPO Papilloma, choroid plexus, nervous system

TNUS Undifferentiated tumor, nervous system

TNXS Glioma, mixed, nervous system

TYCS Chondrosarcoma, heart

TYRO Rhabdomyoma, heart

TYRS Rhabdomyosarcoma, heart

TXFA Fibroadenoma, site specified in comment

TXIS Leiomyosarcoma, site specified in comment

Group 16 <TCON> Connective tissue tumors, other than lymphoreticular and vascular tumors

TEFS Fibrosarcoma, spleen

TKFS Fibrosarcoma, kidney

TLFS Fibrosarcoma, lymph node, site specified in comment

THFO Fibroma, liver

TCFO Fibroma, connective tissue

TCFS Fibrosarcoma, connective tissue

TCSS Undifferentiated connective tissue sarcoma

TMFS Fibrosarcoma, muscle

TMSS Undifferentiated sarcoma, muscle

TBFS Fibrosarcoma, bone

TSFS Fibrosarcoma, skin

TSSS Undifferentiated sarcoma, skin

TIFO Fibroma, gastrointestinal tract

TIFS Fibrosarcoma, gastrointestinal tract

TDFS Fibrosarcoma, urinary bladder

TUFO Fibroma, uterus

TUUS Sarcoma, uterus, undetermined type

TTFA Fibroma, testis

TTFS Fibrosarcoma, testis

TVFO Fibroma, seminal vesicle

TVFS Fibrosarcoma, seminal vesicle

TVSS Undifferentiated sarcoma, seminal vesicle 
$<$ F $>$ MICRO Glossary (Cont.)

TNFO Fibroma, nervous system

TNMS Meningeal sarcoma, nervous system

TYFS Fibrosarcoma, heart

TXFS Fibrosarcoma, site specified in comment

TXUS Undifferentiated sarcoma, site specified in comment

TCMS Mast cell tumor, connective tissue

TCOO Osteoma, connective tissue

TMLS Leiomyosarcoma, muscle

TMRO Rhabdomyoma, muscle

TMRS Rhabdomyosarcoma, muscle

TMSO Leiomyoma, muscle

TBCS Chondrosarcoma, bone

TBOO Osteoma, bone

TBOS Osteosarcoma, bone

TBUS Odontogenic sarcoma, bone

TINO Neurilemmoma, gastrointestinal tract

TISO Leiomyoma, gastrointestinal tract

TISS Leiomyosarcoma, gastrointestinal tract

TDLS Leiomyosarcoma, urinary bladder

TULO Leiomyoma, uterus

TULS Leiomyosarcoma, uterus

TUNO Neurilemmoma, uterus

TNAS Astrocytoma, nervous system

TNNB Ependymoma, nervous system

TNNO Peripheral nerve neurilemmoma (neurofibroma), nervous system

TNNS Peripheral nerve neurofibrosarcoma, nervous system

TNOS Oligodendroglioma, nervous system

TNPO Papilloma, choroid plexus, nervous system

TNUS Undifferentiated tumor, nervous system

TNXS Glioma, mixed, nervous system

TYCS Chondrosarcoma, heart

TYRO Rhabdomyoma, heart

TYRS Rhabdomyosarcoma, heart

TXFA Fibroadenoma, site specified in comment

TXIS Leiomyosarcoma, site specified in comment

Group $17<$ THA_> Liver, hepatocellular tumors

THAA Adenoma (hepatoma)

THAC Hepatocarcinoma

THAO Hyperplastic nodule (pre-neoplastic nodule)

Group $18<$ THC_> Liver, bile duct tumors

THCC Cholangiocarcinoma

THCO Cholangioma (cholangiomatosis) 


\section{<F> MICRO Glossary (Cont.)}

Group $19<$ TAC_> Adrenal cortical tumors

TACC Cortical carcinoma

TACO Cortical adenoma

TAUO Tumor (undetermined cell type)

Group $20<$ TAM_> Adrenal medullary tumors

TANS Medullary neuroblastoma/ganglioneuroma

TAPS Medullary pheochromocytoma

Group $21<$ TOVE $>$ Ovarian tumors

TOAC Adenocarcinoma

TOAO Adenoma (also papillary adenoma)

TOCO Cystadenoma

TOGC Granulosa cell tumor

TOPA Papillary adenoma

TOSC Undifferentiated carcinoma

TOTA Tubular adenoma

TOTO Luteoma (thecoma)

Group $22<$ TOGC> Granulosa cell tumor, ovary

TOGC Granulosa cell tumor

Group $23<$ TOTA $>$ Tubular adenoma, ovary

TOTA Tubular adenoma

Group $24<$ TOTO> Luetoma (thecoma), ovary

TOTO Luteoma (thecoma)

Group $25<$ TOOT> All other ovarian tumors

TOAC Adenocarcinoma

TOAO Adenoma (also papillary adenoma)

TOCO Cystadenoma

TOPA Papillary adenoma

TOSC Undifferentiated carcinoma 


\section{$<$ F $>$ MICRO Glossary (Cont.)}

Group $26<\mathrm{KLOG}>$ Kidney, liver, gastrointestinal system, and other tumors

\section{Kidney}

TKAA Renal adenoma

TKAC Renal tubular tumor (adenocarcinoma)

TKCA Cystadenoma

TKPA Renal papillary adenoma

TKTC Renal pelvic transitional cell tumor

Urinary bladder

TDEC Squamous cell carcinoma

TDTC Transitional cell carcinoma

\section{Liver}
THAA Adenoma (hepatoma)
THAC Hepatocarcinoma
THAO Hyperplastic nodule (pre-neoplastic nodule)
THCC Cholangiocarcinoma
THCO Cholangioma (cholangiomatosis)

Gastrointestinal tract

TIAC Adenocarcinoma

TIAO Adenoma

TIEC Squamous cell carcinoma

TIPL Polyp (plaque), pyloric region

TIPO Polyps

TISC Undifferentiated carcinoma

Skin

TSAO Adenoma

TSBC Basal cell carcinoma (hair follicle tumor)

TSDO Sebaceous gland adenoma

TSEC Squamous cell carcinoma

TSPO Papilloma

Rare tissues with tumors

TXAC Adenocarcinoma, site specified in comment

TXAO Adenoma, site specified in comment

TXEC Squamous cell carcinoma, site specified in comment

Group 27 <MAPU> Mammary gland, adrenal gland, pituitary gland, thyroid gland, uterine, testicular, and seminal vesicle tumors

Mammary gland

TMAA Adenocarcinoma A (alveolar)

TMAB Adenocarcinoma B (ductal, predominantly) 


\section{<F> MICRO Glossary (Cont.)}

TMAC Adenocarcinoma C (fibrosarcoma)

TMAT Adenoacanthoma

TMUO Mammary gland tumor (undetermined type)

Adrenal cortical tumors

TACC Cortical carcinoma

TACO Cortical adenoma

TAUO Tumor (undetermined cell type)

Adrenal medullary tumors

TANS Medullary neuroblastoma/ganglioneuroma

TAPS Medullary pheochromocytoma

Pituitary

TPAA Acidophilic adenoma

TPAC Carcinoma

TPAO Adenoma

Thyroid

TZAC Adenocarcinoma

TZAO Adenoma

Uterus

TUAC Adenocarcinoma

TUAO Adenoma (including papillary type)

TUEC Squamous cell carcinoma

Testis

TTAC Carcinoma

TTGC Seminoma

TTIO Interstitial cell tumor (Leydig)

TTKC Sertoli cell tumor

TTQC Embryonal carcinoma

Seminal vesicle

TVAO Adenoma

TVUO Tumor (undetermined cell type)

Group $28<$ ENDO> Mammary gland, adrenal gland, pituitary gland, thyroid gland, uterine, testicular, seminal vesicle, and Harderian gland tumors

Mammary gland

TMAA Adenocarcinoma A (alveolar)

TMAB Adenocarcinoma B (ductal, predominantly)

TMAC Adenocarcinoma C (fibrosarcoma) 
<F> MiCRO Glossary (Cont.)

TMAT Adenoacanthoma

TMUO Mammary gland tumor (undetermined type)

Adrenal cortical tumors

TACC Cortical carcinoma

TACO Cortical adenoma

TAUO Tumor (undetermined cell type)

Adrenal medullary tumors

TANS Medullary neuroblastoma/ganglioneuroma

TAPS Medullary pheochromocytoma

Pituitary

TPAA Acidophilic adenoma

TPAC Carcinoma

TPAO Adenoma

Thyroid

TZAC Adenocarcinoma

TZAO Adenoma

Uterus

TUAC Adenocarcinoma

TUAO Adenoma (including papillary type)

TUEC Squamous cell carcinoma

Testis

TTAC Carcinoma

TTGC Seminoma

TTIO Interstitial cell tumor (Leydig)

TTKC Sertoli cell tumor

TTQC Embryonal carcinoma

Seminal vesicle

TVAO Adenoma

TVUO Tumor (undetermined cell type)

Harderian gland

TGAC Adenocarcinoma

TGAO Papillary cyst adenoma

TGSC Undifferentiated tumor 


\section{APPENDIX M:}

\section{COMBINED PATHOLOGY DATABASE $<\mathrm{H}>$ :} MACRO AND MUCRO GLOSSARIES 


\section{M-2}




\section{Combined Pathology Database $<\mathrm{H}>$}

\section{MACRO Glossary}

Group $1<$ PR_T $>$ Primary tumors

$\begin{array}{ll}\text { NTYG } & \text { Non-thymic lymphoma, generalized } \\ \text { NTYL } & \text { Non-thymic lymphoma, localized } \\ \text { TTYG } & \text { Thymic lymphoma, generalized } \\ \text { TTYL } & \text { Thymic lymphoma, localized } \\ \text { TVAS } & \text { Vascular } \\ \text { TBON } & \text { Bone } \\ \text { TBRN } & \text { Brain } \\ \text { TCNS } & \text { Central nervous system } \\ \text { TCON } & \text { Connective tissue (fibrosarcoma) } \\ \text { THRT } & \text { Heart } \\ \text { TMIC } & \text { Miscellaneous connective tissue } \\ \text { TMIN } & \text { Miscellaneous nervous system } \\ \text { TMUS } & \text { Muscle } \\ \text { TPNS } & \text { Peripheral nervous system } \\ \text { TSPL } & \text { Spleen } \\ \text { TADN } & \text { Lung } \\ \text { TMIL } & \text { Miscellaneous lung (respiratory system) } \\ \text { TOVE } & \text { Ovary } \\ \text { TGBL } & \text { Gallbladder } \\ \text { TLIV } & \text { Liver } \\ \text { TBLA } & \text { Urinary bladder } \\ \text { TKID } & \text { Kidney } \\ \text { TMUG } & \text { Miscellaneous urogenital } \\ \text { TCEC } & \text { Caecum } \\ \text { TCOL } & \text { Colon } \\ \text { TDUO } & \text { Duodenum } \\ \text { TESO } & \text { Esophagus } \\ \text { TILE } & \text { Ileum } \\ \text { TJEJ } & \text { Jejunum } \\ \text { TMID } & \text { Miscellaneous digestive system } \\ \text { TPAN } & \text { Pancreas } \\ \text { TPYL } & \text { Pylorus } \\ \text { TSGL } & \text { Salivary gland } \\ \text { TSTO } & \text { Stomach } \\ \text { TTGE } & \text { Tongue } \\ \text { THIB } & \text { Hibernating gland } \\ \text { TMIE } & \text { Miscellaneous endocrine } \\ \text { TMIG } & \text { Miscellaneous glandular } \\ \text { TPPT } & \text { Preputial gland } \\ \text { TPST } & \text { Prostate } \\ \text { TSKN } & \text { Skin } \\ \text { TVAG } & \text { Vagina } \\ & \\ & \end{array}$




\section{$<$ H $>$ MACRO Glossary (Cont.)}

$\begin{array}{ll}\text { THGL } & \text { Harderian gland } \\ \text { TPIT } & \text { Pituitary } \\ \text { TTRD } & \text { Thyroid } \\ \text { TSMV } & \text { Seminal vesicle } \\ \text { TTST } & \text { Testis } \\ \text { TCGL } & \text { Cowper's gland } \\ \text { TEPI } & \text { Epididymis } \\ \text { TMGL } & \text { Mammary gland } \\ \text { TUTE } & \text { Uterus } \\ \text { TADR } & \text { Adrenal }\end{array}$

Group $2<\mathrm{CT}$ - $>$ Primary connective tissue tumors

$\begin{array}{ll}\text { NTYG } & \text { Non-thymic lymphoma, generalized } \\ \text { NTYL } & \text { Non-thymic lymphoma, localized } \\ \text { TTYG } & \text { Thymic lymphoma, generalized } \\ \text { TTYL } & \text { Thymic lymphoma, localized } \\ \text { TVAS } & \text { Vascular } \\ \text { TBON } & \text { Bone } \\ \text { TBRN } & \text { Brain } \\ \text { TCNS } & \text { Central nervous system } \\ \text { TCON } & \text { Connective tissue (fibrosarcoma) } \\ \text { THRT } & \text { Heart } \\ \text { TMIC } & \text { Miscellaneous connective tissue } \\ \text { TMIN } & \text { Miscellaneous nervous system } \\ \text { TMUS } & \text { Muscle } \\ \text { TPNS } & \text { Peripheral nervous system } \\ \text { TSPL } & \text { Spleen }\end{array}$

Group $3<\mathrm{EP}$ T $>$ Primary epithelial tumors excluding ovarian tumors

$\begin{array}{ll}\text { TADN } & \text { Lung } \\ \text { TMIL } & \text { Miscellaneous lung (respiratory system) } \\ \text { TGBL } & \text { Gallbladder } \\ \text { TLIV } & \text { Liver } \\ \text { TBLA } & \text { Urinary bladder } \\ \text { TKID } & \text { Kidney } \\ \text { TMUG } & \text { Miscellaneous urogenital } \\ \text { TCEC } & \text { Caecum } \\ \text { TCOL } & \text { Colon } \\ \text { TDUO } & \text { Duodenum } \\ \text { TESO } & \text { Esophagus } \\ \text { TILE } & \text { Ileum } \\ \text { TJEJ } & \text { Jejunum } \\ \text { TMID } & \text { Miscellaneous digestive system } \\ \text { TPAN } & \text { Pancreas }\end{array}$




\section{$<$ H $>$ MACRO Glossary (Cont.)}

$\begin{array}{ll}\text { TPYL } & \text { Pylorus } \\ \text { TSGL } & \text { Salivary gland } \\ \text { TSTO } & \text { Stomach } \\ \text { TTGE } & \text { Tongue } \\ \text { THIB } & \text { Hibernating gland } \\ \text { TMIE } & \text { Miscellaneous endocrine } \\ \text { TMIG } & \text { Miscellaneous glandular } \\ \text { TPPT } & \text { Preputial gland } \\ \text { TPST } & \text { Prostate } \\ \text { TSKN } & \text { Skin } \\ \text { TVAG } & \text { Vagina } \\ \text { THGL } & \text { Harderian gland } \\ \text { TPIT } & \text { Pituitary } \\ \text { TTRD } & \text { Thyroid } \\ \text { TSMV } & \text { Seminal vesicle } \\ \text { TTST } & \text { Testis } \\ \text { TCGL } & \text { Cowper's gland } \\ \text { TEPI } & \text { Epididymis } \\ \text { TMGL } & \text { Mammary gland } \\ \text { TUTE } & \text { Uterus } \\ \text { TADR } & \text { Adrenal }\end{array}$

Group 4 <LR_T> Lymphoreticular tumors

NTYG Non-thymic lymphoma, generalized

NTYL Non-thymic lymphoma, localized

TTYG Thymic lymphoma, generalized

TTYL Thymic lymphoma, localized

Group 5 <TLSA> Lymphosarcoma

Null table Codes in $<\mathrm{MICRO}>$ only

Group 6 <TLRC> Reticulum cell sarcoma

Null table Codes in $<$ MICRO $>$ only

Group 7 <TLLE> Lymphocytic leukemia

Null table Codes in <MICRO $>$ only

Group $8<$ TCAR> All carcinomas

Null table Codes in $<$ MICRO $>$ only 
$<H>$ MACRO Glossary (Cont.)

Group $9<\mathrm{TSAR}>$ All sarcomas

Null table Codes in $\angle$ MICRO $>$ only

Group $10<\mathrm{T} \_\mathrm{FO}>$ All fibromas

Null table Codes in $\angle$ MICRO $>$ only

Group $11<$ TFSA $>$ All fibrosarcomas

Null table Codes in $<$ MICRO $>$ only

Group $12<$ TRAA $>$ Alveologenic adenoma

Null table Codes in $<$ MICRO $>$ only

Group 13 <TRAC> Alveologenic adenocarcinoma

Null table Codes in $<$ MICRO $>$ only

Group $14<\mathrm{TADR}>$ All adrenal tumors

TADR Adrenal

Group $15<$ TAC_> Adrenal cortical tumors

Null table Codes in $\langle$ MICRO $>$ only

Group $16<$ TAM_> Adrenal medullary tumors

Null table Codes in $<$ MICRO $>$ only

Group 17 <THA_> Liver hepatocellular tumors

Null table Codes in $<$ MICRO $>$ only

Group $18<\mathrm{TK} \_>$Kidney tumors

TKID Kidney

Group $19<$ TMGL> Mammary gland tumors

TMGL Mammary gland 


\section{$<\mathrm{H}>$ MACRO Glossary (Cont.)}

Group $20<\mathrm{T}$-GI $>$ Gastrointestinal tract tumors

$\begin{array}{ll}\text { TCEC } & \text { Caecum } \\ \text { TCOL } & \text { Colon } \\ \text { TDUO } & \text { Duodenum } \\ \text { TESO } & \text { Esophagus } \\ \text { TILE } & \text { Ileum } \\ \text { TJEJ } & \text { Jejunum } \\ \text { TMID } & \text { Miscellaneous digestive system } \\ \text { TPAN } & \text { Pancreas } \\ \text { TPYL } & \text { Pylorus } \\ \text { TSGL } & \text { Salivary gland } \\ \text { TSTO } & \text { Stomach } \\ \text { TTGE } & \text { Tongue }\end{array}$

Group $21<\mathrm{TBON}>$ Bone tumors

TBON Bone

Group $22<$ T_WR> Metastases from lung tumor to any site

Null table $\quad$ Codes in $<$ MICRO $>$ only

Group $23<\mathrm{T}$-WK $>$ Metastases from kidney tumor to any site

Null table Codes in $<\mathrm{MICRO}>$ only

Group $24<\mathrm{T}_{-} \mathrm{WG}>$ Metastases from Harderian gland tumor to any site

Null table Codes in $<$ MICRO $>$ only

Group $25<T_{-}$WB $>$Metastases from bone tumor to any site

Null table Codes in $<$ MICRO $>$ only

Group $26<\mathrm{TRW}>$ Metastases from any site to lung

Null table Codes in $<\mathrm{MICRO}>$ only

Group $27<\mathrm{TKW}>$ Metastases from any site to kidney

Null table Codes in $<$ MICRO $>$ only

Group $28<\mathrm{T}_{-} \mathrm{W}_{-}>$All metastatic tumors (secondaries)

TSEC Secondary tumors 


\section{Combined Pathology Database $<\mathrm{H}>$}

\section{MICRO Glossary}

Group $1<$ PR_T> Primary tumors

TLFS Fibrosarcoma, lymph node, site specified in comment

TLHL Histiocytic leukemia

TLHS Histiocytic lymphoma (reticulum cell tumor, type A)

TLLL Lymphocytic-lymphoblastic leukemia

TLLS Lymphocytic-lymphoblastic lymphoma

TLML Myelogenous leukemia

TLPS Plasma cell tumor

TLSL Undifferentiated leukemia

TLSS Undifferentiated lymphoma

TLUS Unclassified lymphoma

TLXL Mixed histiocytic-lymphocytic leukemia

TLXS Mixed histiocytic-lymphocytic lymphoma (RCT, type B)

TEVO Hemangioma, spleen

TLVO Hemangioma, lymphoreticular tissue

TOVO Hemangioma, ovary

THVO Hemangioma, liver

TCVO Hemangioma, connective tissue

TMVO Hemangioma, muscle

TBVO Hemangioma, sternal marrow

TDVO Hemangioma, urinary bladder

TIVO Hemangioma, gastrointestinal tract

TUVO Hemangioma, uterus

TAVO Hemangioma, adrenal

TTVO Hemangioma, testis

TEVS Angiosarcoma, spleen

TLVS Angiosarcoma, lymph node

TRVS Angiosarcoma, lung

TOVS Angiosarcoma, ovary

TKVS Angiosarcoma, kidney

THVS Angiosarcoma, liver

TCVS Angiosarcoma, connective tissue

TMVS Angiosarcoma, muscle

TBVS Angiosarcoma, bone

TSVS Angiosarcoma, skin

TIVS Angiosarcoma, gastrointestinal tract

TDVS Angiosarcoma, urinary bladder

TUVS Angiosarcoma, uterus

TPVS Angiosarcoma, pituitary

TTVS Angiosarcoma, testis

TVVS Angiosarcoma, seminal vesicle

TNVS Angiosarcoma, nervous system

TYVS Angiosarcoma, heart 


\section{$<$ H $>$ MICRO Glossary (Cont.)}

TXVS Angiosarcoma, site specified in comment

TEFS

TKFS

THFO

TCFO

TCFS

TCSS

TMFS

TMSS

TBFS

TSFS

TSSS

TIFO

TIFS

TDFS

TUFO

TUUS

TTFA

TTFS

TVFO

TVFS

TVSS

TNFO

TNMS

TYFS

TXFS

TXUS

TCMS

TCOO

TMLS

TMRO

TMRS

TMSO

TBCS

TBOO

TBOS

TBUS

TINO

TISO

TISS

TDLS

TULO

TULS

TUNO

TNAS

TNNB
Fibrosarcoma, spleen

Fibrosarcoma, kidney

Fibroma, liver

Fibroma, connective tissue

Fibrosarcoma, connective tissue

Undifferentiated connective tissue sarcoma

Fibrosarcoma, muscle

Undifferentiated sarcoma, muscle

Fibrosarcoma, bone

Fibrosarcoma, skin

Undifferentiated sarcoma, skin

Fibroma, gastrointestinal tract

Fibrosarcoma, gastrointestinal tract

Fibrosarcoma, urinary bladder

Fibroma, uterus

Sarcoma, uterus, undetermined type

Fibroma, testis

Fibrosarcoma, testis

Fibroma, seminal vesicle

Fibrosarcoma, seminal vesicle

Undifferentiated sarcoma, seminal vesicle

Fibroma, nervous system

Meningeal sarcoma, nervous system

Fibrosarcoma, heart

Fibrosarcoma, site specified in comment

Undifferentiated sarcoma, site specified in comment

Mast cell tumor, connective tissue

Osteoma, connective tissue

Leiomyosarcoma, muscle

Rhabdomyoma, muscle

Rhabdomyosarcoma, muscle

Leiomyoma, muscle

Chondrosarcoma, bone

Osteoma, bone

Osteosarcoma, bone

Odontogenic sarcoma, bone

Neurilemmoma, gastrointestinal tract

Leiomyoma, gastrointestinal tract

Leiomyosarcoma, gastrointestinal tract

Leiomyosarcoma, urinary bladder

Leiomyoma, uterus

Leiomyosarcoma, uterus

Neurilemmoma, uterus

Astrocytoma, nervous system

Ependymoma, nervous system 


\section{$<$ H> MICRO Glossary (Cont.)}

TNNO Neurofibroma, peripheral nerve neurilemmoma

TNNS Peripheral nerve neurofibrosarcoma

TNOS Oligodendroglioma, nervous system

TNPO Papilloma, choroid plexus, nervous system

TNUS Undifferentiated tumor, nervous system

TNXS Glioma, mixed, nervous system

TYCS Chondrosarcoma, heart

TYRO Rhabdomyoma, heart

TYRS Rhabdomyosarcoma, heart

TXFA Fibroadenoma, site specified in comment

TXLS Leiomyosarcoma, site specified in comment

TANS Medullary neuroblastoma (ganglioneuroma), adrenal

TAPS Medullary pheochromocytoma, adrenal

Respiratory system

TRAA Alveologenic adenoma

TRAC Alveologenic adenocarcinoma

TRCO Cystadenoma

Mammary gland

TMAA Adenocarcinoma A (alveolar)

TMAB Adenocarcinoma B (ductal, predominantly)

TMAC Adenocarcinoma $\mathrm{C}$ (fibrosarcoma)

TMAT Adenoacanthoma

TMUO Mammary gland tumor (undetermined type)

Adrenal cortical tumors

TACC Cortical carcinoma

TACO Cortical adenoma

TAUO Tumor (undetermined cell type)

Pituitary

TPAA

TPAC

Acidophilic adenoma

TPAO Adenoma

Thyroid

TZAC Adenocarcinoma

TZAO Adenoma

Uterus

TUAC Adenocarcinoma

TUAO Adenoma (including papillary type)

TUEC Squamous cell carcinoma 


\section{$<\mathrm{H}>$ MIICRO Glossary (Cont.)}

\section{Testis}

TTAC Carcinoma

TTGC Seminoma

TTIO Interstitial cell tumor (Leydig)

TTKC Sertoli cell tumor

TTQC Embryonal carcinoma

Seminal vesicle

TVAO Adenoma

TVUO Tumor (undetermined cell type)

Harderian gland

TGAC Adenocarcinoma

TGAO Papillary cystadenoma

TGSC Undifferentiated tumor

\section{Kidney}

TKAA Renal adenoma

TKAC Renal tubular tumor (adenocarcinoma)

TKCA Cystadenoma

TKPA Renal papillary cystadenoma

TKTC Renal pelvic transitional cell carcinoma

Urinary bladder

TDEC Squamous cell carcinoma

TDTC Transitional cell carcinoma

Liver

- THAA Adenoma (hepatoma)

THAC Hepatocarcinoma

THAO Hyperplastic nodule (pre-neoplastic nodule)

THCC Cholangiocarcinoma

THCO Cholangioma (cholangiomatosis)

Gastrointestinal tract

TIAC Adenocarcinoma

TIAO Adenoma

TIEC Squamous cell carcinoma

TIPL Plaque (pyloric region; polyp)

TIPO Polyps

TISC Undifferentiated carcinoma

Skin

TSAO Adenoma

TSBC Basal cell carcinoma (hair follicle tumor)

- TSDO Sebaceous gland adenoma 


\section{$<\mathrm{H}>$ MICRO Glossary (Cont.)}

TSEC Squamous cell carcinoma

TSPO Papilloma

Rare tissues with tumors

TXAC Adenocarcinoma, site specified in comment

TXAO Adenoma, site specified in comment

TXEC Squamous cell carcinoma, site specified in comment

Ovary

TOAC

TXAO

TOCO

TOGC

TOPA

TOSC

TOTA

TOTO

Adenocarcinoma

Adenoma

Cystadenoma

Granulosa cell tumor

Papillary adenoma

Undifferentiated carcinoma

Tubular adenoma

Luteoma (thecoma)

Group $2<\mathrm{CT}$ T $>$ Primary connective tissue tumors

TLFS Fibrosarcoma, lymph node, site specified in comment

TLHL Histiocytic leukemia

TLHS Histiocytic lymphoma (reticulum cell tumor, type A)

TLLL Lymphocytic-lymphoblastic leukemia

TLLS Lymphocytic-lymphoblastic lymphoma

TLML Myelogenous leukemia

TLPS Plasma cell tumor

TLSL Undifferentiated leukemia

TLSS Undifferentiated lymphoma

TLUS Unclassified lymphoma

TLXL Mixed histiocytic-lymphocytic leukemia

TLXS Mixed histiocytic-lymphocytic lymphoma (RCT, type B)

TEVO Hemangioma, spleen

TLVO Hemangioma, lymphoreticular tissue

TOVO Hemangioma, ovary

THVO Hemangioma, liver

TCVO Hemangioma, connective tissue

TMVO Hemangioma, muscle

TBVO Hemangioma, sternal marrow

TIVO Hemangioma, gastrointestinal tract

TDVO Hemangioma, urinary bladder

TUVO Hemangioma, uterus

TAVO Hemangioma, adrenal

TTVO Hemangioma, testis

TEVS Angiosarcoma, spleen

TLVS Angiosarcoma, lymph node 


\section{$<$ H> MICRO Glossary (Cont.)}

$\begin{array}{ll}\text { TRVS } & \text { Angiosarcoma, lung } \\ \text { TOVS } & \text { Angiosarcoma, ovary } \\ \text { TKVS } & \text { Angiosarcoma, kidney } \\ \text { THVS } & \text { Angiosarcoma, liver } \\ \text { TCVS } & \text { Angiosarcoma, connective tissue } \\ \text { TMVS } & \text { Angiosarcoma, muscle } \\ \text { TBVS } & \text { Angiosarcoma, bone } \\ \text { TSVS } & \text { Angiosarcoma, skin } \\ \text { TIVS } & \text { Angiosarcoma, gastrointestinal tract } \\ \text { TDVS } & \text { Angiosarcoma, urinary bladder } \\ \text { TUVS } & \text { Angiosarcoma, uterus } \\ \text { TPVS } & \text { Angiosarcoma, pituitary } \\ \text { TTVS } & \text { Angiosarcoma, testis } \\ \text { TVVS } & \text { Angiosarcoma, seminal vesicle } \\ \text { TNVS } & \text { Angiosarcoma, nervous system } \\ \text { TYVS } & \text { Angiosarcoma, heart } \\ \text { TXVS } & \text { Angiosarcoma, site specified in comment } \\ \text { TEFS } & \text { Fibrosarcoma, spleen } \\ \text { TKFS } & \text { Fibrosarcoma, kidney } \\ \text { THFO } & \text { Fibroma, liver } \\ \text { TCFO } & \text { Fibroma, connective tissue } \\ \text { TCFS } & \text { Fibrosarcoma, connective tissue } \\ \text { TCSS } & \text { Undifferentiated connective tissue sarcoma } \\ \text { TMFS } & \text { Fibrosarcoma, muscle } \\ \text { TMSS } & \text { Undifferentiated sarcoma, muscle } \\ \text { TBFS } & \text { Fibrosarcoma, bone } \\ \text { TSFS } & \text { Fibrosarcoma, skin } \\ \text { TSSS } & \text { Undifferentiated sarcoma, skin } \\ \text { TIFO } & \text { Fibroma, gastrointestinal tract } \\ \text { TIFS } & \text { Fibrosarcoma, gastrointestinal tract } \\ \text { TDFS } & \text { Fibrosarcoma, urinary bladder } \\ \text { TUFO } & \text { Fibroma, uterus } \\ \text { TUUS } & \text { Sarcoma, uterus, undetermined type } \\ \text { TTFA } & \text { Fibroma, testis } \\ \text { TTFS } & \text { Fibrosarcoma, testis } \\ \text { TVFO } & \text { Fibroma, seminal vesicle } \\ \text { TVFS } & \text { Fibrosarcoma, seminal vesicle } \\ \text { TVSS } & \text { Undifferentiated sarcoma, seminal vesicle } \\ \text { TNFO } & \text { Fibroma, nervous system } \\ \text { TNMS } & \text { Meningeal sarcoma, nervous system } \\ \text { TYFS } & \text { Fibrosarcoma, heart } \\ \text { TXFS } & \text { Fibrosarcoma, site specified in comment } \\ \text { TXUS } & \text { Undifferentiated sarcoma, site specified in comment } \\ \text { TCOst cell tumor, connective tissue } \\ \end{array}$




\section{$<$ H> MICRO Glossary (Cont.)}

$\begin{array}{ll}\text { TMRO } & \text { Rhabdomyoma, muscle } \\ \text { TMRS } & \text { Rhabdomyosarcoma, muscle } \\ \text { TMSO } & \text { Leiomyoma,muscle } \\ \text { TBCS } & \text { Chondrosarcoma, bone } \\ \text { TBOO } & \text { Osteoma, bone } \\ \text { TBOS } & \text { Osteosarcoma, bone } \\ \text { TBUS } & \text { Odontogenic sarcoma, bone } \\ \text { TINO } & \text { Neurilemmoma, gastrointestinal tract } \\ \text { TISO } & \text { Leiomyoma, gastrointestinal tract } \\ \text { TISS } & \text { Leiomyosarcoma, gastrointestinal tract } \\ \text { TDLS } & \text { Leiomyosarcoma, urinary bladder } \\ \text { TULO } & \text { Leiomyoma, uterus } \\ \text { TULS } & \text { Leiomyosarcoma, uterus } \\ \text { TUNO } & \text { Neurilemmoma, uterus } \\ \text { TNAS } & \text { Astrocytoma, nervous system } \\ \text { TNNB } & \text { Ependymoma, nervous system } \\ \text { TNNO } & \text { Neurofibroma, peripheral nerve neurilemmoma } \\ \text { TNNS } & \text { Peripheral nerve neurofibrosarcoma } \\ \text { TNOS } & \text { Oligodendroglioma, nervous system } \\ \text { TNPO } & \text { Papilloma, choroid plexus, nervous system } \\ \text { TNUS } & \text { Undifferentiated tumor, nervous system } \\ \text { TNXS } & \text { Glioma, mixed, nervous system } \\ \text { TYCS } & \text { Chondrosarcoma, heart } \\ \text { TYRO } & \text { Rhabdomyoma, heart } \\ \text { TYRS } & \text { Rhabdomyosarcoma, heart } \\ \text { TXFA } & \text { Fibroadenoma, site specified in comment } \\ \text { TXLS } & \text { Leiomyosarcoma, site specified in comment } \\ \text { TANS } & \text { Medullary neuroblastoma (ganglioneuroma), adrenal } \\ \text { TAPS } & \text { Medullary pheochromocytoma, adrenal } \\ & \end{array}$

Group $3<$ EP_T $>$ Primary epithelial tumors excluding ovarian tumors

Respiratory system

TRAA Alveologenic tumor adenoma

TRAC Alveologenic tumor adenocarcinoma

TRCO Cystadenoma

Mammary gland

TMAA Adenocarcinoma A (alveolar)

TMAB Adenocarcinoma B (ductal, predominantly)

TMAC Adenocarcinoma C (fibrosarcoma)

TMAT Adenoacanthoma

TMUO Mammary gland tumor (undetermined type) 


\section{$<$ H> MICRO Glossary (Cont.)}

Adrenal cortical tumors

TACC Cortical carcinoma

TACO Cortical adenoma

TAUO Tumor (undetermined cell type)

Pituitary

TPAA

TPAC Carcinoma

TPAO Adenoma

Thyroid

TZAC Adenocarcinoma

TZAO Adenoma

Uterus

TUAC Adenocarcinoma

TUAO Adenoma (including papillary type)

TUEC Squamous cell carcinoma

Testis

TTAC Carcinoma

TTGC Seminoma

TTIO Interstitial cell tumor (Leydig)

TTKC Sertoli cell tumor

TTQC Embryonal carcinoma

Seminal vesicle

TVAO Adenoma

TVUO Tumor (undetermined cell type)

Harderian gland

TGAC Adenocarcinoma

TGAO Papillary cystadenoma

TGSC Undifferentiated tumor

\section{Kidney}

TKAA Renal adenoma

TKAC Renal tubular tumor, adenocarcinoma

TKCA Cystadenoma

TKPA Renal papillary cystadenoma

TKTC Renal pelvic transitional cell carcinoma

Urinary bladder

TDEC Squamous cell carcinoma

TDTC Transitional cell carcinoma 


\section{$<$ H $>$ MICRO Glossary (Cont.)}

Liver

THAA Adenoma (hepatoma)

THAC Hepatocarcinoma

THAO Hyperplastic nodule (pre-neoplastic nodule)

THCC Cholangiocarcinoma

THCO Cholangioma (cholangiomatosis)

Gastrointestinal tract

TIAC Adenocarcinoma

TIAO Adenoma

TIEC Squamous cell carcinoma

TIPL Plaque (pyloric region; polyp)

TIPO Polyps

TISC Undifferentiated carcinoma

Skin

TSAO Adenoma

TSBC Basal cell carcinoma (hair follicle tumor)

TSDO Sebaceous gland adenoma

TSEC Squamous cell carcinoma

TSPO Papilloma

Rare tissues with tumors

TXAC Adenocarcinoma, site specified in comment

TXAO Adenoma, site specified in comment

TXEC Squamous cell carcinoma, site specified in comment

Group $4<\mathrm{LR} \_\mathrm{T}>$ Lymphoreticular tumors

TLHL Histiocytic leukemia

TLHS Histiocytic lymphoma (reticulum cell tumor, type A)

TLLL Lymphocytic-lymphoblastic leukemia

TLLS Lymphocytic-lymphoblastic lymphoma

TLML Myelogenous leukemia

TLPS Plasma cell tumor

TLSL Undifferentiated leukemia

TLSS Undifferentiated lymphoma

TLUS Unclassified lymphoma

TLXL Mixed histiocytic-lymphocytic leukemia

TLXS Mixed histiocytic-lymphocytic lymphoma (RCT, type B)

Group $5<$ TLSA $>$ Lymphosarcoma

TLLS Lymphocytic-lymphoblastic lymphoma

TLUS Unclassified lymphoma

TLSS Undifferentiated lymphoma 
$<$ H> MICRO Glossary (Cont.)

Group 6 <TLRC> Reticulum cell sarcoma

TLHS Histiocytic lymphoma (reticulum cell tumor, type A)

TLXS Mixed histiocytic-lymphocytic lymphoma (RCT, type B)

Group 7 <TLLE> Lymphocytic leukemia

TLLL Lymphocytic-lymphoblastic leukemia

TLHL Histiocytic leukemia

TLML Myelogenous leukemia

TLPS Plasma cell tumor

TLSL Undifferentiated leukemia

TLXL Mixed histiocytic-lymphocytic leukemia

Group $8<\mathrm{TCAR}>$ All carcinomas

TRAC Alveologenic tumor adenocarcinoma

TMAA Mammary gland, adenocarcinoma A (alveolar)

TMAB Mammary gland, adenocarcinoma B (ductal, predominantly)

TMAC Mammary gland, adenocarcinoma $\mathrm{C}$

TACC Adrenal cortical carcinoma

TPAC Pituitary, carcinoma

TZAC Thyroid, adenocarcinoma

TUAC Uterus, adenocarcinoma

TUEC Uterus, squamous cell carcinoma

TTAC Testis, carcinoma

TTQC Testis, embryonal carcinoma

TGAC Harderian gland, adenocarcinoma

TKAC Kidney, renal tubular adenocarcinoma

TKTC Kidney, renal pelvic transitional cell carcinoma

TDEC Urinary bladder, squamous cell carcinoma

TDTC Urinary bladder, transitional cell carcinoma

THAC Liver, hepatocarcinoma

THCC Liver, cholangiocarcinoma

TIAC Gastrointestinal tract, adenocarcinoma

TIEC Gastrointestinal tract, squamous cell carcinoma

TISC Gastrointestinal tract, undifferentiated carcinoma

TSBC Skin, basal cell carcinoma (hair follicle tumor)

TSEC Skin, squamous cell carcinoma

TXAC Rare tissues with tumors, adenocarcinoma, site specified in comment

TXEC Rare tissues with tumors, squamous cell carcinoma, site specified in comment

TOAC Ovary, adenocarcinoma

TOSC Ovary, undifferentiated carcinoma 


\section{$<$ H MICRO Glossary. (Cont.)}

Group 9 <TSAR> All sarcomas

TLFS, Fibrosarcoma; lymph node; site specified in comment

TLHS Histiocytic lymphoma (reticulum cell tumor, type A)

TLLS Ly.mphocytic-lymphoblastic lymphoma

TLSS Undifferentiated lymphoma

TLUS: Unclassified lymphoma

TLXS Mixed histiocytic-lymphatic lymphoma (RCT, type B)

TEVS Angiosarcoma, spleen

TLVS- Angiosarcoma, lymph node

TRVS Angiosarcoma, lung.

TOVS Angiosarcoma, avary

T:KVV: Angiosarcoma, kìiney

THVS Angiosarcoma; liver:

TCV.S Angiosarcoma;. connective tissue

TMVS. Angiöarcoma, muscle.

TBVS Angiosarcoma; bone

TSVS Angiosareomas. skin

TIVS: Aingiosarcoma; gastrointestinal tract

TDVS: Angiosarcoma; urinary bladder

TUVS Angiosarcoma; uterus.

TPVS Angiosarcoma, pituitary.

TTVS Angiosarcoma, testis:

TVVS Angiosarcoma, seminal vesicle

TNV.S Angiosarcoma, nervous system

TYVS Angiosarcoma, beart

TXVS Angiosarcoma, site specified in comment

TEES Fibrosarcoma, spleen:

TKFS Fibrosarcoma, kidney

TCFS Fibrosarcoma; connective tissue

TCSS Undifferentiated connective tissue sarcoma

TMES: Fibrosarcoma, muscle

TMSS: Undiffèrentiated sarcoma, muscle

TBFS, Fibrosarcoma, bone

TSFS Fibrosarcoma, skin

TSSS Undiffèrentiated: sarcoma, skin

TIFS: Fibrosarcoma, gastrointestinal tract

TDES: Fibrosarcoma; urinary bladder

TUUS Sarcoma, uterus, undetermined type

TTES: Fibrosarcoma, testis

TV.FS: Fibrosarcoma, seminal vesicle

TVSS; Undiffèrentiatedi sarcoma, seminal vesicle-

TNMS: Meningeal sarcoma, nervous system:

TYFS, Fibrosarcoma, heartt

TXFS: Fibrosarcoma; site specified in comment

TXUS Undifferentiated sarcoma, site specified in comment 


\section{$<$ H > MICRO Glossary (Cont.)}

TCMS Mast cell tumor, connective tissue

TMLS Leiomyosarcoma, muscle

TMRS Rhabdomyosarcoma, muscle

TBCS Chondrosarcoma, bone

TBOS Osteosarcoma, bone

TBUS Odontogenic sarcoma, bone

TISS Leiomyosarcoma, gastrointestinal tract

TDLS Leiomyosarcoma, urinary bladder

TULS Leiomyosarcoma, uterus

TNNS Peripheral nerve neurofibrosarcoma

TYCS Chondrosarcoma, heart

TYRS Rhabdomyosarcoma, heart

TXLS Leiomyosarcoma, site specified in comment

Group $10<$ T_FO> All fibromas

THFO Fibroma, liver

TCFO Fibroma, connective tissue

TIFO Fibroma, gastrointestinal tract

TUFO Fibroma, uterus

TTFA Fibroma, testis

TVFO Fibroma, seminal vesicle

TNFO Fibroma, nervous system

Group $11<$ TFSA> All fibrosarcomas

$\begin{array}{ll}\text { TEFS } & \text { Fibrosarcoma, spleen } \\ \text { TKFS } & \text { Fibrosarcoma, kidney } \\ \text { TCFS } & \text { Fibrosarcoma, connective tissue } \\ \text { TMFS } & \text { Fibrosarcoma, muscle } \\ \text { TBFS } & \text { Fibrosarcoma, bone } \\ \text { TSFS } & \text { Fibrosarcoma, skin } \\ \text { TIFS } & \text { Fibrosarcoma, gastrointestinal tract } \\ \text { TDFS } & \text { Fibrosarcoma, urinary bladder } \\ \text { TLFS } & \text { Fibrosarcoma, lymph node } \\ \text { TTFS } & \text { Fibrosarcoma, testis } \\ \text { TVFS } & \text { Fibrosarcoma, seminal vesicle } \\ \text { TXFS } & \text { Fibrosarcoma, site specified in comment } \\ \text { TYFS } & \text { Fibrosarcoma, heart }\end{array}$

Group $12<$ TRAA $>$ Alveologenic adenoma

TRAA Alveologenic adenoma 


\section{$<\mathrm{H}>$ MICRO Glossary (Cont.)}

Group 13 <TRAC> Alveologenic adenocarcinoma

TRAC Alveologenic adenocarcinoma

Group $14<$ TADR $>$ All adrenal tumors

TACC Cortical carcinoma

TACO Cortical adenoma

TAUO Tumor (undetermined cell type)

TANS Medullary neuroblastoma (ganglioneuroma)

TAPS Medullary pheochromocytoma

Group $15<$ TAC_> Adrenal cortical tumors

TACC Cortical carcinoma

TACO Cortical adenoma

TAUO Tumor (undetermined cell type)

Group 16 <TAM_> Adrenal medullary tumors

TANS Medullary neuroblastoma (ganglioneuroma)

TAPS Medullary pheochromocytoma

Group $17<$ THA_> Liver, hepatocellular tumors

THAA Adenoma (hepatoma)

THAC Hepatocarcinoma

THAO Hyperplastic nodule (pre-neoplastic nodule)

Group $18<\mathrm{TK} \_>$Kidney tumors

TKAA Renal adenoma

TKAC Renal tubular adenocarcinoma

TKCA Cystadenoma

TKPA Renal papillary cystadenoma

TKTC Renal pelvic transitional cell tumor

Group 19 <TMGL> Mammary gland tumors

TMAA Adenocarcinoma A (alveolar)

TMAB Adenocarcinoma B (ductal, predominantly)

TMAC Adenocarcinoma C

TMAT Adenoacanthoma

TMUO Mammary gland tumor (undetermined type) 


\section{$<$ H $>$ MICRO Glossary (Cont.)}

Group $20<\mathrm{T}$-GI $>$ Gastrointestinal tract tumors

$\begin{array}{ll}\text { TIAC } & \text { Adenocarcinoma } \\ \text { TIAO } & \text { Adenoma } \\ \text { TIEC } & \text { Squamous cell carcinoma } \\ \text { TIPL } & \text { Plaque (pyloric region; polyp) } \\ \text { TIPO } & \text { Polyps } \\ \text { TISC } & \text { Undifferentiated carcinoma } \\ \text { TIFO } & \text { Fibroma, gastrointestinal tract } \\ \text { TIFS } & \text { Fibrosarcoma, gastrointestinal tract } \\ \text { TISO } & \text { Leiomyoma, gastrointestinal tract } \\ \text { TISS } & \text { Leiomyosarcoma, gastrointestinal tract } \\ \text { TIVO } & \text { Hemangioma, gastrointestinal tract } \\ \text { TIVS } & \text { Angiosarcoma, gastrointestinal tract } \\ \text { TINO } & \text { Neurilemmoma, gastrointestinal tract }\end{array}$

Group $21<\mathrm{TBON}>$ Bone tumors
TBFS Fibrosarcoma, bone
TBVS Angiosarcoma, bone
TBOO Osteoma, bone
TBOS Osteosarcoma, bone
TBCS Chondrosarcoma, bone
TBUS Odontogenic sarcoma, bone

Group $22<\mathrm{T}_{-} \mathrm{WR}>$ Metastases from lung tumor to any site

$\begin{array}{ll}\text { TAWR } & \text { Metastasis to adrenal } \\ \text { TBWR } & \text { Metastasis to bone } \\ \text { TCWR } & \text { Metastasis to connective tissue } \\ \text { THWR } & \text { Metastasis to liver } \\ \text { TKWR } & \text { Metastasis to kidney } \\ \text { TLWR } & \text { Metastasis to lymphoreticular tissue } \\ \text { TMWR } & \text { Metastasis to muscle } \\ \text { TNWR } & \text { Metastasis to nervous system } \\ \text { TXWR } & \text { Metastasis to tissue specified in comment } \\ \text { TYWR } & \text { Metastasis to heart }\end{array}$

Group $23<\mathrm{T}$-WK $>$ Metastases from kidney tumor to any site

TAWK Metastasis to adrenal

TCWK Metastasis to connective tissue

TEWK Metastasis to spleen

THWK Metastasis to liver

TLWK Metastasis to lymphoreticular tissue

TMWK Metastasis to muscle 
$<$ H> MICRO Glossary (Cont.)

TNWK Metastasis to nervous system

TRWK Metastasis to respiratory system

TXWK Metastasis to tissue specified in comment

TYWK Metastasis to heart

Group $24<\mathrm{T}$-WG $>$ Metastases from Harderian gland tumor to any site

TBWG Metastasis to bone

TCWG Metastasis to connective tissue

THWG Metastasis to liver

TKWG Metastasis to kidney

TLWG Metastasis to lymphoreticular tissue

TMWG Metastasis to muscle

TNWG Metastasis to nervous system

TRWG Metastasis to respiratory system

TXWG Metastasis to tissue specified in comment

TYWG Metastasis to heart

Group $25<\mathrm{T}_{-} \mathrm{WB}>$ Metastases from bone tumor to any site

TCWB Metastatis to connective tissue

TEWB Metastasis to spleen

THWB Metastasis to liver

TIWB Metastasis to gastrointestinal tract

TKWB Metastasis to kidney

TLWB Metastasis to lymphoreticular tissue

TMWB Metastasis to muscle

TNWB Metastasis to nervous system

TOWB Metastasis to ovary

TRWB Metastasis to respiratory system

TSWB Metastasis to skin

TXWB Metastasis to tissue specified in comment

TYWB Metastasis to heart

Group $26<\mathrm{TRW}>$ Metastases from any site to lung

TRWA Origin, adrenal

TRWB Origin, bone

TRWC Origin, connective tissue

TRWG Origin, Harderian gland

TRWH Origin, liver

TRWI Origin, gastrointestinal tract

TRWK Origin, kidney

TRWM Origin, muscle or mammary gland (tissue specified in comment)

TRWN Origin, nervous system

TRWO Origin, ovary 


\section{$<$ H $>$ MICRO Glossary (Cont.)}

$\begin{array}{ll}\text { TRWP } & \text { Origin, pituitary } \\ \text { TRWS } & \text { Origin, skin } \\ \text { TRWT } & \text { Origin, testis } \\ \text { TRWU } & \text { Origin, uterus } \\ \text { TRWV } & \text { Origin, seminal vesicle } \\ \text { TRWX } & \text { Origin, tissue specified in comment } \\ \text { TRWY } & \text { Origin, heart } \\ \text { TRWZ } & \text { Origin, thyroid }\end{array}$

Group $27<\mathrm{TKW}>>$ Metastases from any site to kidney

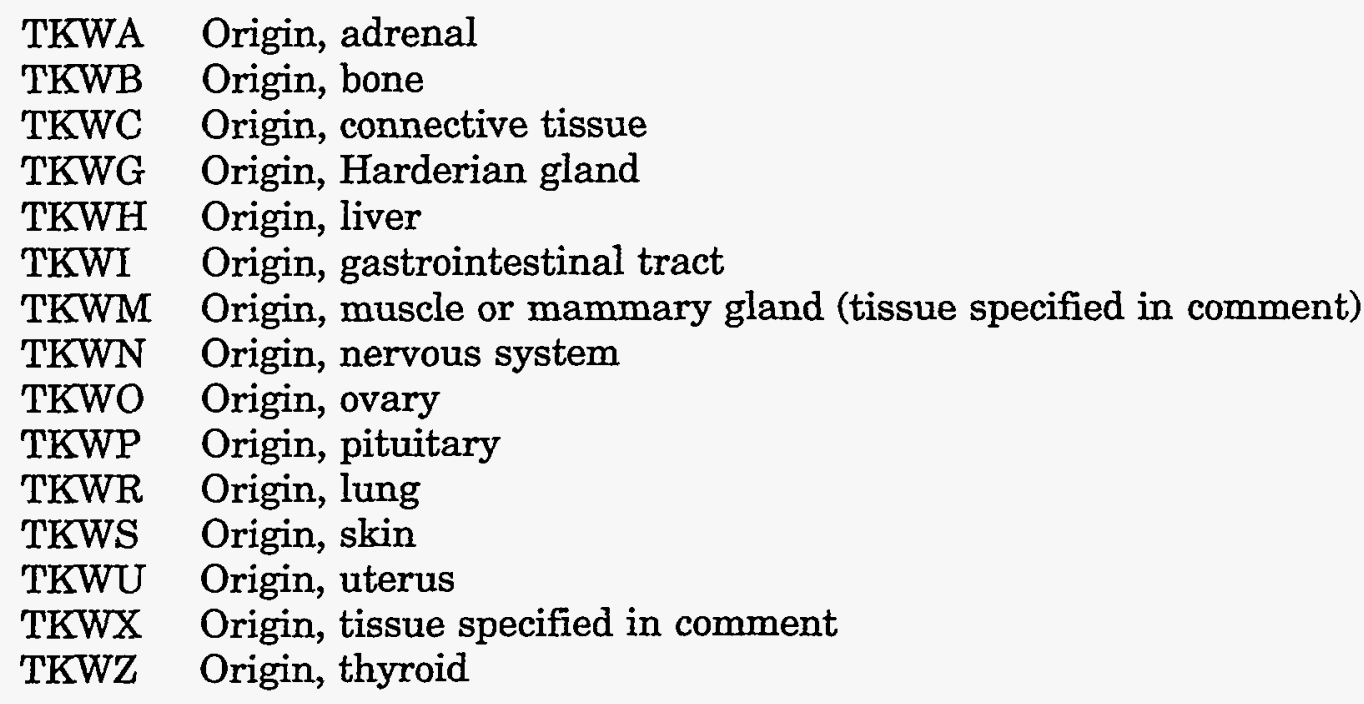

Group $28<\mathrm{T}_{-} \mathrm{W}_{-}>$All metastatic tumors (secondaries)

Lymphoreticular tissue

$\begin{array}{ll}\text { TLWA } & \text { Origin, adrenal } \\ \text { TLWB } & \text { Origin, bone } \\ \text { TLWC } & \text { Origin, connective tissue } \\ \text { TLWG } & \text { Origin, Harderian gland } \\ \text { TLWH } & \text { Origin, liver } \\ \text { TLWI } & \text { Origin, gastrointestinal tract } \\ \text { TLWK } & \text { Origin, kidney } \\ \text { TLWM } & \text { Origin, muscle } \\ \text { TLWN } & \text { Origin, nervous system } \\ \text { TLWO } & \text { Origin, ovary } \\ \text { TLWP } & \text { Origin, pituitary } \\ \text { TLWR } & \text { Origin, lung } \\ \text { TLWS } & \text { Origin, skin } \\ \text { TLWT } & \text { Origin, testis } \\ \text { TLWU } & \text { Origin, uterus } \\ \text { TLWX } & \text { Origin, tissue specified in comment }\end{array}$




\section{$<\mathrm{H}>$ MICRO Glossary (Cont.)}

TLWY Origin, heart

TLWZ Origin, thyroid

Lung

TRWA Origin, adrenal

TRWB Origin, bone

TRWC Origin, connective tissue

TRWG Origin, Harderian gland

TRWH Origin, liver

TRWI Origin, gastrointestinal tract

TRWK Origin, kidney

TRWM Origin, muscle or mammary gland (tissue specified in comment)

TRWN Origin, nervous system

TRWO Origin, ovary

TRWP Origin, pituitary

TRWS Origin, skin

TRWT Origin, testis

TRWU Origin, uterus

TRWV Origin, seminal vesicle

TRWX Origin, tissue specified in comment

TRWY Origin, heart

TRWZ Origin, thyroid

Ovary

TOWB Origin, bone

TOWU Origin, uterus

TOWX Origin, tissue specified in comment

Kidney

TKWA Origin, adrenal

TKWB Origin, bone

TKWC Origin, connective tissue

TKWG Origin, Harderian gland

TKWH Origin, liver

TKWI Origin, gastrointestinal tract

TKWM Origin, muscle or mammary gland (tissue specified in comment)

TKWN Origin, nervous system

TKWO Origin, ovary

TKWP Origin, pituitary

TKWR Origin, lung

TKWS Origin, skin

TKWU Origin, uterus

TKWX Origin, tissue specified in comment

TKWZ Origin, thyroid 


\section{$<\mathrm{H}>$ MICRO Glossary (Cont.)}

Liver

THWA Origin, adrenal .

THWB Origin, bone

THWC Origin, connective tissue

THWD Origin, urinary bladder

THWG Origin, Harderian gland

THWI Origin, gastrointestinal tract

THWK Origin, kidney

THWM Origin, muscle

THWN Origin, nervous system

THWO Origin, ovary

THWP Origin, pituitary

THWR Origin, lung

THWS Origin, skin

THWU Origin, uterus

THWV Origin, seminal vesicle

THWX Origin, tissue specified in comment

THWY Origin, heart

THWZ Origin, thyroid

Connective tissue

TCWA Origin, adrenal

TCWB Origin, bone

TCWD Origin, urinary bladder

TCWG Origin, Harderian gland

TCWH Origin, liver

TCWI Origin, gastrointestinal tract

TCWK Origin, kidney

TCWN Origin, nervous tissue

TCWO Origin, ovary

TCWP Origin, pituitary

TCWR Origin, lung

TCWS Origin, skin

TCWZ Origin, thyroid

Muscle

TMWA Origin, adrenal

TMWB Origin, bone

TMWC Origin, connective tissue

TMWD Origin, urinary bladder

TMWG Origin, Harderian gland

TMWH Origin, liver

TMWK Origin, kidney

TMWM Origin, mammary gland

TMWN Origin, nervous system

TMWR Origin, lung 


\section{$<H>$ MICRO Glossary (Cont.)}

TMWS Origin, skin

TMWT Origin, testis

TMWX Origin, tissue specified in comment

TMWZ Origin, thyroid

Bone

TBWG Origin, Harderian gland

TBWM Origin, muscle

TBWN Origin, nervous tissue

TBWR Origin, lung

TBWS Origin, skin

TBWX Origin, tissue specified in comment

Skin

TSWB Origin, bone

TSWC Origin, connective tissue

TSWN Origin, nervous system

Gastrointestinal tract

TIWB Origin, bone

TIWM Origin, muscle or mammary gland (tissue specified in comment)

TIWO Origin, ovary

TIWT Origin, testis

TIWU Origin, uterus

TIWZ Origin, thyroid

Urinary bladder

TDWX Origin, tissue specified in comment

Adrenal

TAWI Origin, gastrointestinal tract

TAWK Origin, kidney

TAWM Origin, muscle

TAWO Origin, ovary

TAWR Origin, lung

TAWS Origin, skin

TAWU Origin, uterus

TAWZ Origin, thyroid

Harderian gland

TGWC Origin, connective tissue

TGWS Origin, skin

Nervous system

TNWB Origin, bone

TNWC Origin, connective tissue 


\section{$<\mathrm{H}>$ MICRO Glossary (Cont.)}

TNWG Origin, Harderian gland

TNWK Origin, kidney

TNWM Origin, muscle

TNWO Origin, ovary

TNWR Origin, lung

TNWS Origin, skin

TNWP Origin, pituitary

TNWX Origin, tissue specified in comment

Heart

TYWA Origin, adrenal

TYWB Origin, bone

TYWC Origin, connective tissue

TYWG Origin, Harderian gland

TYWH Origin, liver

TYWK Origin, kidney

TYWM Origin, muscle

TYWO Origin, ovary

TYWR Origin, lung

TYWS Origin, skin

TYWT Origin, testis

TYWU Origin, uterus

TYWX Origin, tissue specified in comment

Rare tissues with tumors, metastatic site specified in comment

TXWB Origin, bone

TXWC Origin, connective tissue

TXWG Origin, Harderian gland

TXWI Origin, gastrointestinal tract

TXWK Origin, kidney

TXWM Origin, muscle

TXWO Origin, ovary

TXWP Origin, pituitary

TXWR Origin, lung

TXWS Origin, skin

TXWU Origin, uterus

TXWV Origin, seminal vesicle

Spleen

TEWB Origin, bone

TEWC Origin, connective tissue

TEWD Origin, urinary bladder

TEWH Origin, liver

TEWK Origin, kidney

TEWM Origin, muscle

TEWS Origin, skin 


\section{$<$ H $>$ MICRO Glossary (Cont.)}

TEWT Origin, testis

TEWU Origin, uterus

\section{Uterus}

TUWO Origin, ovary

Seminal vesicle

TVWD Origin, urinary bladder

TVWX Origin, tissue specified in comment 


\section{APPENDIX N:}

\section{LIST OF SELECTED JANUS PUBLICATIONS}


$N-2$ 


\section{List of Selected JANUS Publications}

Ainsworth, E.J., R.J.M. Fry, P.C. Brennan, S.P. Stearner, J.H. Rust, and F.S. Williamson, 1976, Life shortening, neoplasia and systemic injuries in mice after single or fractionated doses of neutron or gamma radiation, in Biological and Environmental Effects of Low-Level Radiation, vol. 1, International Atomic Energy Agency, Vienna, pp. 77-92.

Ainsworth, E.J., R.J.M. Fry, D. Grahn, F.S. Williamson, P.C. Brennan, S.P. Stearner, A.V. Carrano, and J.H. Rust, 1974, Late effects of neutron or gamma irradiation in mice, in Biological Effects of Neutron Irradiation, International Atomic Energy Agency, Vienna, pp. 359-379; STI/PUB/352.

Ainsworth, E.J., R.J.M. Fry, F.S. Williamson, P.C. Brennan, S.P. Stearner, V.V. Yang, D.A. Crouse, J.H. Rust, and T.B. Borak, 1977, Dose-effect relationships for life shortening, tumorigenesis, and systemic injuries in mice irradiated with fission neutron or ${ }^{60} \mathrm{Co}$ gamma radiation, in Proceedings of IVth International Congress of the International Radiation Protection Association, vol. 4: 1143-1151.

Ainsworth, E.J., D.L. Jordan, M. Miller, E.M. Cooke, and J.S. Hulesch, 1976, Dose rate studies with fission spectrum neutrons, Radiation Research 67(1):30-45.

Ando, K., H. Ohara, S. Matsushita, S. Koike, S. Furukawa, and D.J. Grdina, 1989, Radioprotection from fast neutron irradiation by WR151327, Scientific Papers of the Institute of Physical and Chemical Research (Japan) 83:40-41.

Basic, I., D.J. Grdina, and T. Lyons, 1991, Application of an in vivo mutagenesis system to assess aminothiol effects on neutron-induced genotoxic damage in mouse splenocytes, Anticarcinogenesis and Radiation Protection 2, O.F. Nygaard and A.C. Upton (eds.), Plenum, New York, pp. 297-301.

Borak, T.B., 1975, A simple approach to calculating gamma ray SKYSHINE for reduced shielding applications, Health Physics 29(3):423-425.

Borak, T.B., and T.G. Stinchcomb, 1979, Calculations of charged-particle recoils, slowing-down spectra, LET and event-size distributions for fast neutrons and comparisons with measurements, Physics in Medicine \& Biology 24(1):18-36.

Borak, T.B., and T.G. Stinchcomb, 1979, Quality factor calculations for neutron spectra below $4 \mathrm{MeV}$, Health Physics 36(6):687-693.

Borak, T.B., and T.G. Stinchcomb, 1980, Quality factor for charged particle recoils as a function of neutron energy, Health Physics 38(1):85-88. 
Brennan, P.C., and E.J. Ainsworth, 1977, Early and late effects of fission-neutron or gamma irradiation on the clearance of bacteria from the lungs of $\mathrm{B}_{6} \mathrm{CF}_{1}$ mice, in Pulmonary Macrophage and Epithelial Cells, C.L. Sanders, R.P. Schneider, G.E. Dagle, and H.A. Ragan (eds.), Energy Research and Development Administration, Oak Ridge, pp. 552-565; CONF-760927.

Cairnie, A.B., D. Grahn, H.B. Rayburn, F.S. Williamson, and R.J. Brown, 1974, Teratogenic and embryo lethal effects in mice of fission-spectrum neutrons and gamma-rays, Teratology 10(2):133-139.

Carnes, B.A., and D. Grahn, 1991, Issues about neutron effects: the JANUS program, Radiation Research 128(1 Suppl.):S141-146.

Carnes, B.A., D. Grahn, and J.F. Thomson, 1989, Dose-response modeling of life shortening in a retrospective analysis of the combined data from the JANUS program at Argonne National Laboratory, Radiation Research 119(1):39-56.

Carnes, B.A., and D.J. Grdina, 1992, In vivo protection by the aminothiol WR-2721 against neutron-induced carcinogenesis, International Journal of Radiation Biology 61(5):567-576.

Carrano, A.V., 1975, Induction of chromosomal aberrations in human lymphocytes by $\mathrm{x}$-rays and fission neutrons: dependence on cell cycle stage, Radiation Research 63(3): $403-421$.

Frigerio, N.A., and R.F. Coley, 1973, Depth dose determinations. III. Standard man phantom and various gamma sources, Physics in Medicine \& Biology 18(2):187-194.

Frigerio, N.A., R.F. Coley, and M.H. Branson, 1973, Depth dose determinations. II. A Monte Carlo program and a standard man phantom for neutron and gamma computations, Physics in Medicine \& Biology 18(1):53-63.

Frigerio, N.A., R.F. Coley, and M.J. Sampson, 1972, Depth dose determinations. I. Tissue-equivalent liquids for standard man and muscle, Physics in Medicine \& Biology 17(6):792-802.

Fry, R.J.M., 1977, Radiation carcinogenesis, International Journal of Radiation Oncology Biology Physics 3:219-226.

Fry, R.J.M., and E.J. Ainsworth, 1977, Radiation injury: some aspects of the oncogenic effects, Federation Proceedings 36(5):1703-1707.

Fry, R.J.M., and B.A. Carnes, 1989, Age, sex and other factors in radiation carcinogenesis, in Low Dose Radiation: Biological Bases of Risk Assessment, K.F. Baverstock and J.W. Stather (eds.), Taylor and Francis, London, pp. 195-206. 
Fry, R.J.M., A.G. Garcia, K.H. Allen, A. Sallese, E. Staffeldt, T.N. Tahmisian, R.L. Devine, L.S. Lombard, and E.J. Ainsworth, 1976, Effect of pituitary isografts on radiation carcinogenesis in mammary and Harderian glands of mice, in Biological and Environmental Effects of Low-Level Radiation, vol. 1, International Atomic Energy Agency, Vienna, pp. 213-27.

Fry, R.J.M., D. Grahn, M.L. Griem, and J.H. Rust (eds.), Late Effects of Radiation, 1970, proceedings of the Colloquium on Late Effects of Radiation, held in Chicago, Illinois, in May 1969, Van Nostrand Reinhold, New York, 306 pp.

Fry, R.J., E.C. Gregg, R.B. Painter, and W.C. Roesch, 1972, High-LET radiation in radiotherapy: a report from the Radiation Study Section of the National Institutes of Health, Radiology 103(1):215-220.

Fry, R.J.M., R.D. Ley, D. Grube, and E. Staffeldt, 1982, Studies on the multistage nature of radiation carcinogenesis, in Cocarcinogenesis and Biological Effects of Tumor Promoters, E. Hecker, N.E. Fusenig, W. Kunz, F. Marks, and H.W. Thielmann (eds.), Raven Press, New York, pp. 155-165.

Fry, R.J.M., E. Staffeldt, and S.A. Tyler, 1978, Some problems arising in analysis of large-scale animal irradiation experiments, Environment International 1(6):361-366.

Garriott, M.L., and D. Grahn, 1982, Neutron and gamma-ray effects measured by the micronucleus test, Mutation Research 105(3):157-162.

Giometti C.S., S.L. Tollaksen, and D. Grahn, 1994, Altered protein expression detected in the F1 offspring of male mice exposed to fission neutrons, Mutation Research 320(1-2):75-85.

Grahn, D., 1969, Late effects of external irradiations in animals and the prediction of lowdose effects, in Biological Implications of the Nuclear Age, Atomic Energy Commission symposium series 16, pp. 269-81; CONF-69030.

Grahn, D., 1970, Biological effects of protracted low dose radiation exposure of man and animals, in Late Effects of Radiation, R.J.M. Fry, D. Grahn, M.L. Griem, and J.H. Rust (eds.), Van Nostrand Reinhold, New York, pp. 101-36.

Grahn, D., 1972, Genetic problems related to radiology practices, Radiology 105(3):653-657.

Grahn, D., 1983, Genetic risks associated with radiation exposures during space flight, Advances in Space Research 3:161-170.

Grahn, D., E.J. Ainsworth, F.S. Williamson, and R.J.M. Fry, 1972, A program to study fission neutron-induced chronic injury in cells, tissues, and animal populations, utilizing the JANUS reactor of the Argonne National Laboratory, in Radiobiological Applications of Neutron Irradiation, International Atomic Energy Agency, Vienna, pp. 211-228; STI/PUB/325. 
Grahn, D., and B.A. Carnes, 1987, Relative Biological Effectiveness (RBE) of Fission Neutrons and Gamma Rays at Occupational Exposure Levels. Volume I. Studies on the Genetic Effects in Mice of 60 Equal Once-Weekly Exposures to Fission Neutrons and Gamma Rays, Argonne National Laboratory report ANL-86-33, vol. I (NUREG/CR-4704, vol. I), $71 \mathrm{pp}$.

Grahn, D., and B.A. Carnes, 1988, Genetic injury in hybrid male mice exposed to low doses of ${ }^{60} \mathrm{Co}$ gamma-rays or fission neutrons. III. Frequencies of abnormal sperm and reciprocal translocations measured during and following long-term weekly exposures, Mutation Research 198(2):285-294.

Grahn, D., B.A. Carnes, and B.H. Farrington, 1986, Genetic injury in hybrid male mice exposed to low doses of ${ }^{60} \mathrm{Co}$ gamma-rays or fission neutrons. II. Dominant lethal mutation response to long-term weekly exposures, Mutation Research 162(1):81-89.

Grahn, D., B.A. Carnes, B.H. Farrington, and C.H. Lee, 1984, Genetic injury in hybrid male mice exposed to low doses of ${ }^{60}$ Co gamma-rays or fission neutrons. I. Response to single doses, Mutation Research 129(2):215-229.

Grahn, D., and T.E. Fritz, 1986, Chronic radiation injury with mice and dogs exposed to external whole-body irradiation at the Argonne National Laboratory, in Life-Span Radiation Effects Studies in Animals: What Can They Tell Us? R.C. Thompson and J.A. Mahaffey (eds.), DOE symposium series 58, Office of Scientific and Technical Information, Oak Ridge, pp. 14-31.

Grahn, D., R.J.M Fry, and R.A. Lea, 1972, Analysis of survival and cause of death statistics for mice under single and duration-of-life gamma irradiation, Life Sciences and Space Research X:175-186.

Grahn, D., B.H. Frystak, C.H. Lee, J.J. Russell, and A. Lindenbaum, 1979, Dominant lethal mutations and chromosome aberrations induced in male mice by incorporated ${ }^{239} \mathrm{Pu}$ and by external fission neutron and gamma irradiation, in Biological Implications of Radionuclides Released from Nuclear Industries, International Atomic Energy Agency, Vienna, pp. 163-182; IAEA-SM-237/50.

Grahn, D., C.H. Lee, and B.F. Farrington, 1983, Interpretation of cytogenetic damage induced in the germ line of male mice exposed for over 1 year to ${ }^{239} \mathrm{Pu}$ alpha particles, fission neutrons, or ${ }^{60}$ Co gamma rays, Radiation Research 95(3):566-583.

Grahn, D., L.S. Lombard, and B.A. Carnes, 1992, The comparative tumorigenic effects of fission neutrons and cobalt-60 gamma rays in the $B 6 \mathrm{CF}_{1}$ mouse, Radiation Research 129(1):19-36. 
Grahn, D., G.A. Sacher, R.A. Lea, R.J.M. Fry, and J.H. Rust, 1978, Analytical approaches to and interpretations of data on time, rate and cause of death of mice exposed to external gamma irradiation, in Late Biological Effects of Ionizing Radiation, vol. II, International Atomic Energy Agency, Vienna, pp. 43-58.

Grahn, D., J.F. Thomson, and B.A. Carnes, 1990, Relative Biological Effectiveness (RBE) of Fission Neutrons and Gamma Rays at Occupational Exposure Levels. Volume III. Studies on the Gross and Microscopic Pathology Observed at Death of Mice Exposed to 60 Equal Once-Weekly Doses of Fission Neutrons and Gamma Rays, Argonne National Laboratory report ANL-86-33, vol. III (NUREG/CR-4704, vol. II), 111 pp.

Grahn, D., J.F. Thomson, B.A. Carnes, F.S. Williamson, and L.S. Lombard, 1986, Comparative biological effects of low dose, low dose-rate exposures to fission neutrons from the JANUS reactor or to ${ }^{60} \mathrm{Co}$ gamma rays, Nuclear Science Applications 2:385-396.

Grdina, D.J., B.A. Carnes, D. Grahn, and C.P. Sigdestad, 1991, Protection against late effects of radiation by $S$-2-(3-aminopropylamino)-ethylphosphorothioic acid, Cancer Research 51(16):4125-4130.

Grdina, D.J., B.A. Carnes, and B. Nagy, 1992, Protection by WR-2721 and WR-151327 against late effects of gamma rays and neutrons, Advances in Space Research 12(2):257-263.

Grdina, D.J., Y., Kataoka, I. Basic, and J. Perrin, 1992, The radioprotector WR-2721 reduces neutron-induced mutations at the hypoxanthine-guanine phosphoribosyl transferase locus in mouse splenocytes when administered prior to or following irradiation, Carcinogenesis 13(5):811-814.

Grdina, D.J., and B. Nagy, 1986, The effect of 2-[(aminopropyl)amino]ethanethiol (WR1065) on radiation-induced DNA damage and repair and cell progression in V79 cells, British Journal of Cancer 54(6):933-941.

Grdina, D.J., B. Nagy, C.K. Hill, R.L. Wells, and C. Peraino, 1985, The radioprotector WR1065 reduces radiation-induced mutations at the hypoxanthine-guanine phosphoribosyl transferase locus in V79 cells, Carcinogenesis 6(6):929-931.

Grdina, D.J., B. Nagy, C.K. Hill, and C.P. Sigdestad, 1989, Protection against radiation-induced mutagenesis in V79 cells by 2-[(aminopropyl)amino] ethanethiol under conditions of acute hypoxia, Radiation Research 117(2):251-258.

Grdina, D.J., B. Nagy, and P.J. Meechan, 1991, Effect of an aminothiol (WR-1065) on radiation-induced mutagenesis and cytotoxicity in two repair-deficient mammalian cell lines, in Anticarcinogenesis and Radiation Protection 2, O.F. Nygaard and A.C. Upton (eds.), Plenum, New York, pp. 287-295. 
Grdina, D.J., and C.P. Sigdestad, 1989, Radiation protectors: the unexpected benefits, Drug Metabolism Reviews 20(1):13-42.

Grdina D.J., and C.P. Sigdestad, 1992, Chemical protection and cell-cycle effects on radiation-induced mutagenesis, Cell Proliferation 25(1):23-29.

Grdina, D.J., C.P. Sigdestad, and B.A. Carnes, 1989, Protection by WR1065 and WR151327 against fission-neutron-induced mutations at the HGPRT locus in V79 cells, Radiation Research 117(3):500-510.

Grdina, D.J., C.P. Sigdestad, P.J. Dale, and J.M. Perrin, 1989, The effect of 2-[(aminopropyl)amino]ethanethiol on fission-neutron-induced DNA damage and repair, British Journal of Cancer 59(1):17-21.

Grdina, D.J., B.J. Wright, and B.A. Carnes, 1991, Protection by WR-151327 against late-effect damage from fission-spectrum neutrons, Radiation Research 128(1 Suppl.):S124-127.

Hanson, W.R., and D.J. Grdina, 1987, Radiation-induced DNA single-strand breaks in the intestinal mucosal cells of mice treated with the radioprotectors WR-2721 or 16-16 dimethyl prostaglandin E2, International Journal of Radiation Biology 52(1):67-76.

Hanson, W.R., and D.J. Grdina, 1991, Misoprostol, a PGE1 analog, protects mice from fission-neutron injury, Radiation Research 128(1 Suppl.):S1217.

Hill, C.K. B.A. Carnes, A. Han, and M.M. Elkind, 1985, Neoplastic transformation is enhanced by multiple low doses of fission-spectrum neutrons, Radiation Research 102(3):404-410.

Hill, C.K. B. Nagy, C. Peraino, and D.J. Grdina, 1986, 2-[(Aminopropyl)amino]ethanethiol (WR1065) is anti-neoplastic and anti-mutagenic when given during ${ }^{60} \mathrm{Co}$ gamma-ray irradiation, Carcinogenesis 7(4):665-668.

Hubbard, L.B., and F.S. Williamson, 1969, Gamma-ray doses for all points in spheres and cylinders with uniformly distributed sources, Physics in Medicine \& Biology 14(2):255-267.

Hubbard, L.B., and F.S. Williamson, 1971, Scatter corrections in bounded media for the doses from internally emitted gamma rays, Physics in Medicine \& Biology 16(1):35-46.

Kataoka, Y., I. Basic, J. Perrin, and D.J. Grdina, 1992, Antimutagenic effects of radioprotector WR-2721 against fission-spectrum neutrons and ${ }^{60} \mathrm{Co}$ gamma-rays in mice, International Journal of Radiation Biology 61(3):387-392.

Kataoka, Y., J. Perrin, and D.J. Grdina, 1993, Induction of hprt mutations in mice after exposure to fission-spectrum neutrons or ${ }^{60} \mathrm{Co}$ gamma rays, Radiation Research 136(2):289-292. 
Marshall, I.R., and F.S. Williamson, 1985, Microdosimetric spectra measurements of JANUS neutrons, Radiation Protection Dosimetry 13:111-115.

Nagy, B., D.J. Grdina, and C.R. Ashman, 1991, JANUS neutron irradiation of a mouse cell line containing a shuttle vector plasmid, in Anticarcinogenesis and Radiation Protection 2, O.F. Nygaard and A.C. Upton (eds.), Plenum, New York, pp. 85-92.

Norris, W.P., S.A. Tyler, and G.A. Sacher, 1976, An interspecies comparison of responses of mice and dogs to continuous ${ }^{60} \mathrm{Co}$ gamma irradiation, in Biological and Environmental Effects of Low-Level Radiation, vol. 1, International Atomic Energy Agency, Vienna, pp. 147-56.

Peak, M.J., J.G. Peak, B.A. Carnes, C.M. Liu, and C.K. Hill, 1989, DNA damage and repair in rodent and human cells after exposure to JANUS fission spectrum neutrons: a minor fraction of single-strand breaks as revealed by alkaline elution is refractory to repair, International Journal of Radiation Biology 55(5):761-772.

Sacher, G.A., 1970, Models from radiation toxicity data, in Late Effects of Radiation, R.J.M. Fry, D. Grahn, M.L. Griem, and J.H. Rust (eds.), Van Nostrand Reinhold, New York, pp. 233-244.

Sacher, G.A. (ed.), 1971, Conference on the Estimation of Low-Level Radiation Effects in Human Populations, Argonne National Laboratory report ANL-7811, 42 pp.

Sacher, G.A., 1973, Dose dependence for life shortening by x-rays, gamma rays, and fast neutrons, in Advances in Radiation Research. Biology and Medicine. Vol. III, J.F. Duplan and A. Chapiro (eds.), Gordon and Breach, New York, pp. 1425-1432.

Sacher, G.A., 1976, Dose, dose rate, radiation quality, and host factors for radiation-induced life shortening, in Aging, Carcinogenesis, and Radiation Biology, K.C. Smith (ed.), Plenum, New York, pp. 493-517.

Sacher, G.A., 1978, 1976 Robert W. Kleemeier Award lecture: Longevity, aging, and death: an evolutionary perspective, Gerontologist 18(2):112-119.

Sacher, G.A., 1978, Quadratic dose dependence for life shortening in mammals: experimental data and a mechanistic model, in Summary and Proceedings of a Biology Workshop on Biological Repair Mechanisms and Exposure Standards, D. Billen (ed.), Oak Ridge Associated Universities report ORAU/IEA-78-2(R) pp. 158-176.

Sacher, G.A., 1978, Stochastic mortality theory and the mortality potential: a biophysical model for certain competing risks, Environment International 1(6):381-389.

Sacher, G.A., D. Grahn, R.J.M. Fry, and J.H. Rust, 1970, Epidemiological and cellular effects of chronic radiation exposure: a search for relationship, in Proceedings of the First European Symposium on Late Effects of Radiation, Comitato Nazionale per l'Energia Nucleare, Rome, Italy, pp. 15-38. 
Sacher, G.A., and R.W. Hart, 1978, Longevity, aging and comparative cellular and molecular biology of the house mouse, Mus musculus, and the white-footed mouse, Peromyscus leucopus, Birth Defects 14(1):71-96.

Sacher, G.A., and E. Staffeldt, 1971, Species differences in sensitivity of myomorph and sciuromorph rodents to life shortening by chronic gamma irradiation, in Radionuclides in Ecosystems, D.J. Nelson (ed.), National Technical Information Service, Springfield, VA, pp. 1042-1047; CONF-710501-P2.

Sacher, G.A., S.A. Tyler, and E. Trucco, 1978, The quadratic low-LET dose-effect relation for life shortening in mammals: implications for the assessment of the low-dose hazard to human populations, in Late Biological Effects of Ionizing Radiation, vol. II, International Atomic Energy Agency, Vienna, pp. 359-378.

Schwartz, J.L., S.M. Giovanazzi, T. Karrison, C. Jones, and D.J. Grdina, 1988, 2 -[(Aminopropyl)amino]ethanethiol-mediated reductions in ${ }^{60} \mathrm{Co}$ gamma-ray and fission-spectrum neutron-induced chromosome damage in V79 cells, Radiation Research 113(1):145-154.

Scott, B.R., and E.J. Ainsworth, 1980, State-vector model for life shortening in mice after brief exposures to low doses of ionizing radiation, Mathematical Biosciences 49:185-205.

Sigdestad, C.P., B.L. Bergquist, and D.J. Grdina, 1991, The effect of chemical radiation protectors on cell cycle progression after gamma or neutron irradiation, Cell Proliferation 24(3):271-280.

Sigdestad, C.P., D.J. Grdina, A.M. Connor, and W.R. Hanson, 1986, A comparison of radioprotection from three neutron sources and ${ }^{60} \mathrm{Co}$ by WR-2721 and WR-151327, Radiation Research 106(2):224-233.

Sigdestad, C.P., S.H. Treacy, L.A. Knapp, and D.J. Grdina, 1987, The effect of 2-[(aminopropyl)amino]ethanethiol (WR-1065) on radiation induced DNA double strand damage and repair in V79 cells, British Journal of Cancer 55(5):477-482.

Sinclair, W.K., 1968, Radiation survival in synchronous and asynchronous Chinese hamster cells in vitro, in Biophysical Aspects of Radiation Quality, International Atomic Energy Agency, Vienna, pp. 39-54.

Sinclair, W.K., 1985, Experimental RBE values of high-LET radiations at low doses and the implications for quality factor assignment, Radiation Protection Dosimetry 13(1-4):319-326.

Stearner, S.P., and E.J. Christian, 1978, Long-term vascular effects of ionizing radiations in the mouse: capillary blood flow, Radiation Research 73(3):553-567. 
Stearner, S.P., R.L. Devine, and E.J. Christian, 1976, Late changes in the irradiated microvasculature: an electron microscope study of the effects of fission neutrons, Radiation Research 65(2):351-370.

Stearner, S.P., V.V. Yang, and R.L. Devine, 1979, Cardiac injury in the aged mouse: comparative ultrastructural effects of fission spectrum neutrons and gamma rays, Radiation Research 78(3):429-447.

Thompson, J.F., and D. Grahn, 1987, Relative Biological Effectiveness (RBE) of Fission Neutrons and Gamma Rays at Occupational Exposure Levels. Volume II. Studies on the Effects of 60 Equal Once-Weekly Exposures to Fission Neutrons and Gamma Rays on Survival of Mice, Argonne National Laboratory report ANL-86-33, vol. II (NUREG/CR-4704, vol. II), $42 \mathrm{pp}$.

Thomson, J.F., and D. Grahn, 1988, Life shortening in mice exposed to fission neutrons and gamma rays. VII. Effects of 60 once-weekly exposures, Radiation Research 115(2):347-360.

Thomson, J.F., and D. Grahn, 1989, Life shortening in mice exposed to fission neutrons and gamma rays. VIII. Exposures to continuous gamma radiation, Radiation Research 118(1):151-160.

Thomson, J.F., L.S. Lombard, D. Grahn, F.S. Williamson, and T.E. Fritz, 1982, RBE of fission neutrons for life shortening and tumorigenesis, in Neutron Carcinogenesis, Commission of the European Communities, Luxembourg, pp. 75-93; EUR-8084.

Thomson, J.F., F.S. Williamson, and D. Grahn, 1983, Life shortening in mice exposed to fission neutrons and gamma rays. III. Neutron exposures of 5 and $10 \mathrm{rad}$, Radiation Research 93(1):205-209.

Thomson, J.F., F.S. Williamson, and D. Grahn, 1985, Life shortening in mice exposed to fission neutrons and gamma rays. IV. Further studies with fractionated neutron exposures, Radiation Research 103(1):77-88.

Thomson, J.F., F.S. Williamson, and D. Grahn, 1985, Life shortening in mice exposed to fission neutrons and gamma rays. V. Further studies with single low doses, Radiation Research 104(3):420-428.

Thomson, J.F., F.S. Williamson, and D. Grahn, 1986, Life shortening in mice exposed to fission neutrons and gamma rays. VI. Studies with the white-footed mouse, Peromyscus leucopus, Radiation Research 108(2):176-188.

Thomson, J.F., F.S. Williamson, D. Grahn, and E.J. Ainsworth, 1981, Life shortening in mice exposed to fission neutrons and gamma rays. I. Single and short-term fractionated exposures, Radiation Research 86(3):559-572. 
Thomson, J.F., F.S. Williamson, D. Grahn, and E.J. Ainsworth, 1981, Life shortening in mice exposed to fission neutrons and gamma rays. II. Duration-of-life and long-term fractionated exposures, Radiation Research 86(3):573-579.

Williamson, F.S., The dosimetry of mixed fields of neutron and gamma radiation: a review, in Symposium on Neutrons in Radiobiology, held at Oak Ridge, Tennessee, November 11-14, 1969, National Technical Information Service, Springfield, VA, pp. 3-11; CONF-691106.

Williamson, F.S., and N.A. Frigerio, 1972, Field mapping and depth dosimetry in the Janus high flux irradiation room-a fast-neutron facility for biological research, in Proceedings of the First Symposium on Neutron Dosimetry in Biology and Medicine, vol. II, Commission of the European Communities, Luxembourg, EUR-4896 (II), pp. $743-755$.

Williamson, F.S., and P. Mitacek Jr., 1967, Calculations of kerma due to fast neutrons in tissue-like materials, in Neutron Monitoring for Radiological Protection, International Atomic Energy Agency, Vienna, pp. 17-26.

van Beek, M.E., R.L. Doak, C.P. Sigdestad, and D.J. Grdina, 1990, Pathological effects of the radiation protector WR-151327 in mice, Radiation Research 124(1):79-84.

Vaughan, A.T., D.J. Grdina, P.J. Meechan, A.E. Milner, and D.J. Gordon, 1989, Conformational changes in chromatin structure induced by the radioprotective aminothiol, WR 1065, British Journal of Cancer 60(6):893-896.

Yang, V.V., S.P. Stearner, and E.J. Ainsworth, 1978, Late ultrastructural changes in the mouse coronary arteries and aorta after fission neutron or ${ }^{60} \mathrm{Co}$ gamma irradiation, Radiation Research 74(3):436-456.

Yang, V.V., S.P. Stearner, and S.A. Tyler, 1976, Radiation-induced changes in the fine structure of the heart: comparison of fission neutrons and ${ }^{60} \mathrm{Co}$ gamma rays in the mouse, Radiation Research 67(2):344-360. 
1967

Williamson and Mitacek

1968

Sinclair

1969

Grahn

Hubbard and Williamson

Williamson

1970

Fry, Grahn, Griem, and Rust

Grahn

Sacher

Sacher, Grahn, Fry, and Rust

1971

Hubbard and Williamson

Sacher

Sacher and Staffeldt

1972

Frigerio, Coley, and Sampson

Fry, Gregg, Painter, and Roesch

Grahn

Grahn, Ainsworth, Williamson, and Fry

Grahn, Fry, and Lea

Williamson and Frigerio

\section{3}

Frigerio and Coley

Frigerio, Coley, and Branson

Sacher

1974

Ainsworth, Fry, Grahn, Williamson, Brennan, Stearner, Carrano, and Rust Cairnie, Grahn, Rayburn, Williamson, and Brown

1975

Borak

Carrano 
1976

Ainsworth, Fry, Brennan, Stearner, Rust, and Williamson

Ainsworth, Jordan, Miller, Cooke, and Hulesch

Fry, Garcia, Allen, Sallese, Staffeldt, Tahmisian, Devine, Lombard, and Ainsworth

Norris, Tyler, and Sacher

Sacher

Stearner, Devine, and Christian

Yang, Stearner, and Tyler

1977

Ainsworth, Fry, Williamson, Brennan, Stearner, Yang, Crouse, Rust, and Borak Brennan and Ainsworth

Fry

Fry and Ainsworth

1978

Fry, Staffeldt, and Tyler

Grahn, Sacher, Lea, Fry, and Rust

Sacher, a

Sacher, b

Sacher, c

Sacher and Hart

Sacher, Tyler, and Trucco

Stearner and Christian

Yang, Stearner, and Ainsworth

1979

Borak and Stinchcomb, a Borak and Stinchcomb, b

Grahn, Frystak, Lee, Russell, and Lindenbaum

Stearner, Yang, and Devine

1980

Borak and Stinchcomb

Scott and Ainsworth

1981

Thomson, Williamson, Grahn, and Ainsworth, a

Thomson, Williamson, Grahn, and Ainsworth, b

1982

Fry, Ley, Grube, and Staffeldt

Garriott and Grahn

Thomson, Lombard, Grahn, Williamson, and Fritz

1983

Grahn

Grahn, Lee, and Farrington

Thomson, Williamson, and Grahn 
1984

Grahn, Carnes, Farrington, and Lee

1985

Grdina, Nagy, Hill, Wells, and Peraino

Hill, Carnes, Han, and Elkind

Marshall and Williamson

Sinclair

Thomson, Williamson, and Grahn, a

Thomson, Williamson, and Grahn, b

1986

Grahn, Carnes, and Farrington

Grahn and Fritz

Grahn, Thomson, Carnes, Williamson, and Lombard

Grdina and Nagy

Hill, Nagy, Peraino, and Grdina

Sigdestad, Grdina, Connor, and Hanson

Thomson, Williamson, and Grahn

1987

Grahn and Carnes

Hanson and Grdina

Sigdestad, Treacy, Knapp, and Grdina

Thomson and Grahn

1988

Grahn and Carnes

Schwartz, Giovanazzi, Karrison, Jones, and Grdina

Thomson and Grahn

1989

Ando, Ohara, Matsushita, Koike, Furukawa, and Grdina

Carnes, Grahn, and Thomson

Fry and Carnes

Grdina, Nagy, Hill, and Sigdestad

Grdina and Sigdestad

Grdina, Sigdestad, and Carnes

Grdina, Sigdestad, Dale, and Perrin

Peak, Peak, Carnes, Liu, and Hill

Thomson and Grahn

Vaughan, Grdina, Meechan, Milner, and Gordon

\section{0}

Grahn, Thomson, and Carnes

van Beek, Doak, Sigdestad, and Grdina 
1991

Basic, Grdina, and Lyons

Carnes and Grahn

Grdina, Carnes, Grahn, and Sigdestad

Grdina, Nagy, and Meechan

Grdina, Wright, and Carnes

Hanson and Grdina

Nagy, Grdina, and Ashman

Sigdestad, Bergquist, and Grdina

\section{2}

Carnes and Grdina

Grahn, Lombard, and Carnes

Grdina, Carnes, and Nagy

Grdina, Kataoka, Basic, and Perrin

Grdina and Sigdestad

Kataoka, Basic, Perrin, and Grdina

1993

Kataoka, Perrin, and Grdina

1994

Giometti, Tollaksen, and Grahn 


\section{DISTRIBUTION FOR ANL-95/3}

Internal

ANL Technical Publications Services

N. Clodi (2)

D.E. Nadziejka (2)

B.A. Carnes (100)

\section{External}

U.S. Department of Energy Office of Scientific and Technical Information (12)

Manager, U.S. Department of Energy Chicago Field Office

ANL-E Libraries (2)

ANL-W Library 